CARLOS HENRIQUE DE OLIVEIRA

\title{
DA TUTELA DAS INFORMAÇÕES SOCIAIS DO TRABALHADOR À GARANTIA EFETIVA DE ACESSO AOS BENEFÍCIOS PREVIDENCIÁRIOS
}

TESE DE DOUTORADO

UNIVERSIDADE DE SÃO PAULO

FACULDADE DE DIREITO DO LARGO DE SÃO FRANCISCO 
CARLOS HENRIQUE DE OLIVEIRA

\section{DA TUTELA DAS INFORMAÇÕES SOCIAIS DO TRABALHADOR À GARANTIA EFETIVA DE ACESSO AOS BENEFÍCIOS PREVIDENCIÁRIOS}

Tese apresentada à Banca Examinadora da Faculdade de Direito da Universidade de São Paulo, como exigência parcial para a obtenção do título de Doutor em Direito do Trabalho e da Seguridade Social, sob orientação do Professor Titular Nelson Mannrich. 
BANCA EXAMINADORA 
À minha mãe, Daíse, por ter, acima de tudo, ensinado, por exemplos diários, os verdadeiros valores da vida.

Ao meu pai, Dorival, que mesmo tendo sido chamado por Deus quando eu ainda era um menino, mostrou a importância do esforço e da dedicação aos nossos propósitos.

Ao meu avô, Narciso, por tudo, pela minha vida.

À minha esposa, Nilda, pela incansável espera e por todo o apoio e carinho.

Aos meus filhos, por me ensinarem a amar incondicionalmente. 


\section{AGRADECIMENTOS}

Ao Professor Nelson Mannrich, mais que um orientador, um exemplo de vida, agradeço pelas oportunidades e apoio incondicional.

Ao Professor Ari Possidonio Beltran, pela ajuda ao longo de todo o percurso. 


\section{RESUMO}

Atualmente, para obter um benefício previdenciário o segurado da Previdência Social deve agendar seu comparecimento a uma agência munido de seu documento pessoal. Comprovado seu direito terá o benefício imediatamente concedido. Essa concessão de maneira tão célere e desburocratizada só é possível graças a informatização dos dados sociais dos trabalhadores brasileiros filiados à Previdência Social. O banco de dados que armazena as informações cadastrais, os vínculos, as remunerações e todos os demais dados necessários para a concessão de um benefício previdenciário é denominado Cadastro Nacional de Informações Sociais, CNIS. O abastecimento desses dados sociais do trabalhador é realizado principalmente pela Guia de Informações ao FGTS e à Previdência Social, GFIP, que é um documento preenchido mensalmente pela empresa do qual constam todos os dados dos trabalhadores que serão armazenados no Cadastro Nacional. A GFIP tem dupla natureza jurídica, natureza de obrigação tributária acessória e obrigação legal de cunho social. Essa, como visto acima, se consubstancia pela característica de instrumento de abastecimento dos dados sociais com vistas à implementação dos direitos previdenciários do trabalhador. Aquela, de obrigação tributária acessória, exsurge ao recordarmos que a GFIP contém todos os valores da remuneração percebida pelo trabalhador, que é base de cálculo das contribuições sociais previdenciárias devidas pela empresa e pelo próprio segurado. Em alteração promovida pela Lei n 11.941 , de 2009, a sanção pelo descumprimento do dever de preencher e enviar a GFIP foi alterada. Criou-se multa moratória de expressiva monta no caso de descumprimento das obrigações relacionadas à GFIP. Porém, o pagamento do tributo acrescido da multa aplicada não garante que as informações sociais necessárias à concessão dos benefícios previdenciários cheguem ao CNIS. Nem mesmo após a fiscalização e punição da empresa inadimplente. Não há, hoje em dia, proteção legal aos dados sociais dos trabalhadores brasileiros e nesse sentido, não há garantias de que a concessão dos benefícios previdenciários seja regularmente realizada. O presente estudo, após analisar com a profundidade necessária a questão, submete uma proposta de alteração legislativa objetivando a garantia das informações sociais do trabalhador e assim efetiva tutela de seus direitos sociais. 


\begin{abstract}
Nowadays in order to receive the retirement plan benefit, the employee needs to go to the closest office with his /her personal documents. Once it is confirmed the worker rights, the benefits will be available to the employees. This simple transaction is only possible through all Brazilian workers social data base which is linked to Social Security. CNIS (Cadastro Nacional de Informações Sociais) is the System responsible for storing all data base information and employees paychecks. The collection of all workers social data is mainly maintained by Guia de Informações to FGTS and Previdência Social (GFIP).There is a monthly document filled by employers which contains all workers data. This data afterwards will be stored at Cadastro National. GFIP has a double juridical nature since it implies in tax and social obligation. As mentioned above, it is based as an instrument of social data storage to implement employees retirement plan rights. The tax obligation is the calculation of employees and employers contributions based on all workers received paychecks. Since the approval of the law 11.941 in 2009, the obligation of filling and sending information to GFIP changed. It was imposed a heavy penalty for those not fulfilling GFIP obligations. But still heavy penalties do not guarantee that the necessary social information gets to CNIS. Not even after the companies that are failing to do so have been inspected and punished. There is not, nowadays, legal protection to the Brazilian workers social data compromising retirement benefits. The proposal of this study, after deeply analysis of the issues mentioned above, is to request a change in the legislation in order to guarantee the workers social information as well as the employees social rights.
\end{abstract}

Key Words: GFIP - CNIS - Benefits - Contributions - Social Security 


\section{SUMÁRIO}

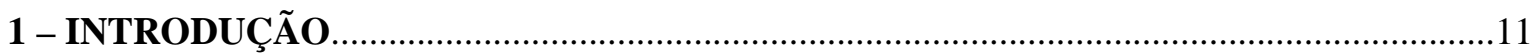

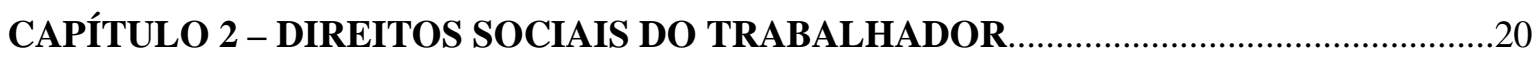

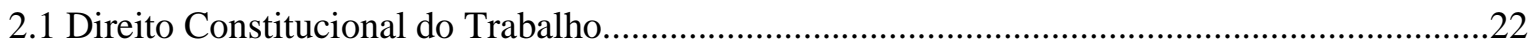

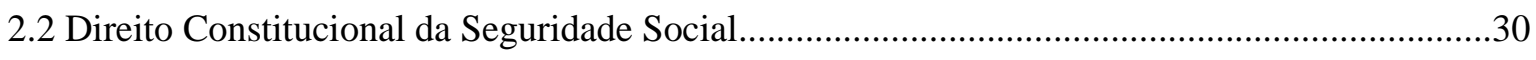

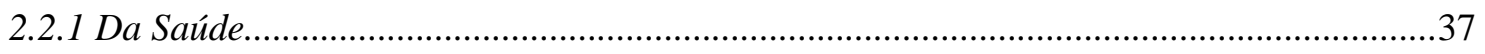

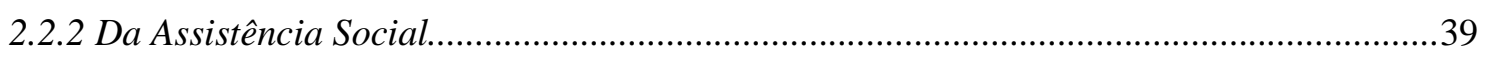

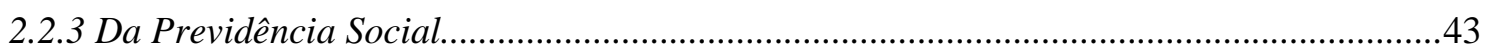

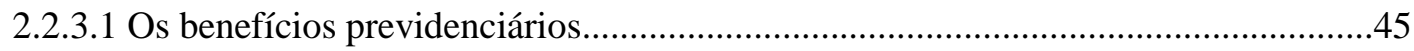

CAPÍTULO 3 - BENEFÍCIOS PREVIDENCIÁRIOS EM OUTROS ORDENAMENTOS

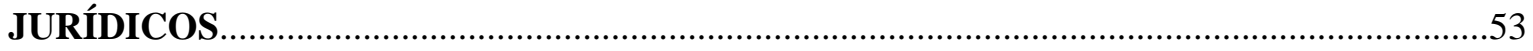

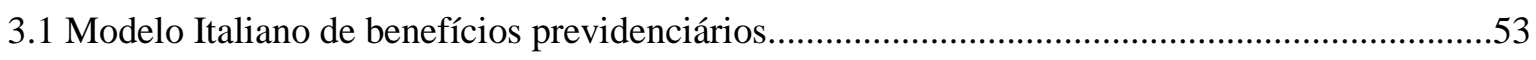

3.1.1 Breves considerações iniciais: evolução histórica e modelo adotado.................................53

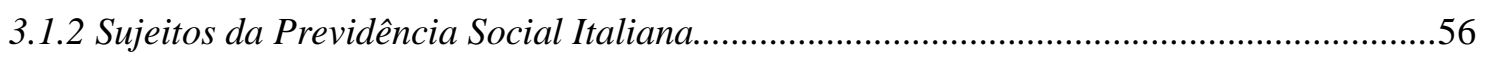

3.1.3 Eventos cobertos pela Previdência Social e forma de financiamento..................................57

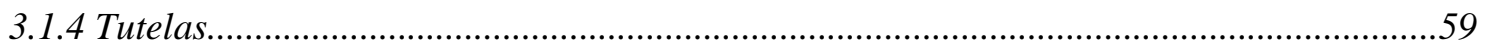

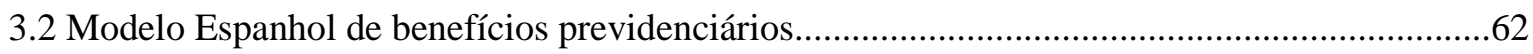

3.2.1 Breves considerações iniciais: evolução histórica e modelo adotado..................................62

3.2.2 Sujeitos da Previdência Social Espanhola..........................................................................67

3.2.3 Eventos cobertos pela Previdência Social e forma de financiamento..................................68

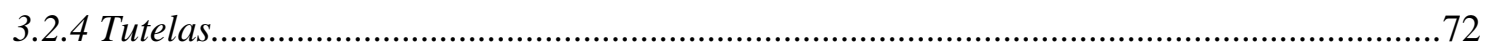

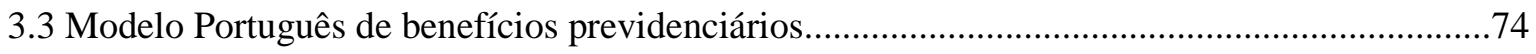

3.3.1 Breves considerações iniciais: evolução histórica e modelo adotado..................................75

3.3.2 Sujeitos da Previdência Social Portuguesa........................................................................78

3.3.3 Eventos cobertos pela Previdência Social e forma de financiamento..................................83

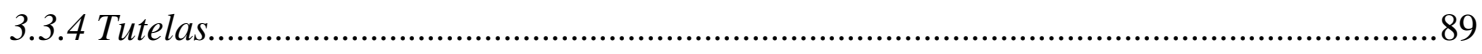

CAPÍTULO 4 - ASPECTOS RELEVANTES DA GFIP - GUIA DE RECOLHIMENTO DO

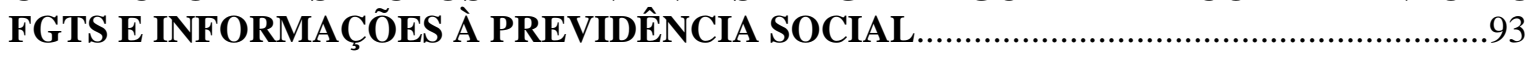

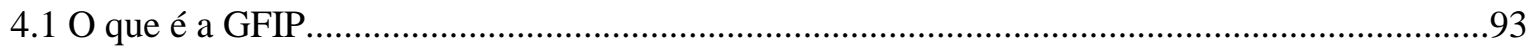

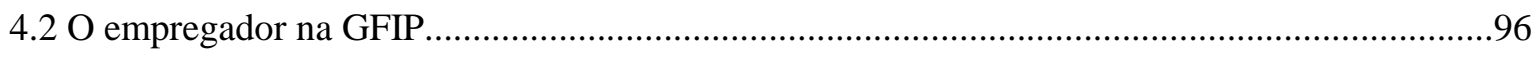

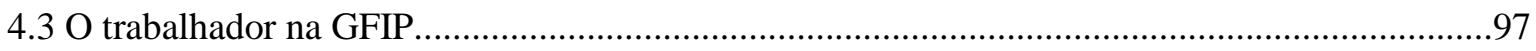

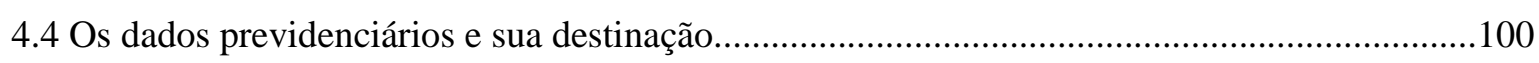

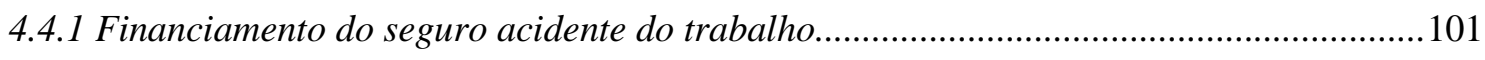

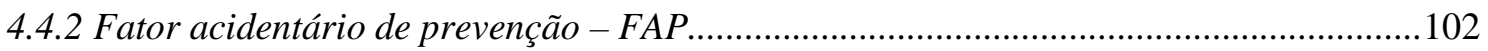




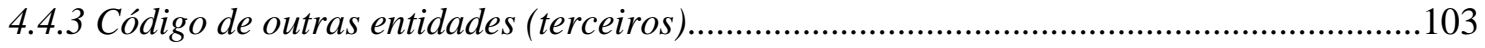

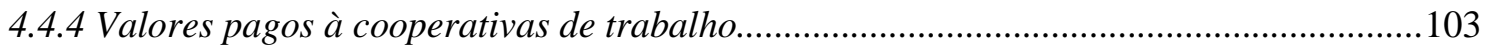

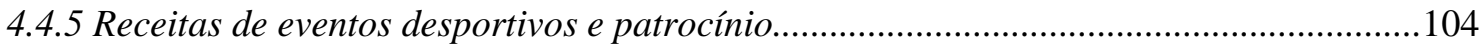

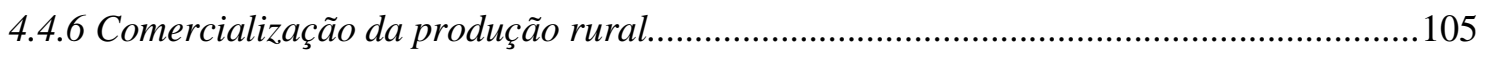

4.4.7 Prestação de serviços mediante cessão de mão-de-obra: retenção dos $11 \%$.....................106

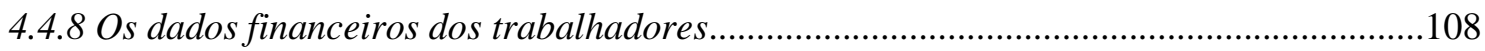

4.5 Os dados relativos ao FGTS e sua destinação.............................................................................111

CAPÍTULO 5 - NATUREZA JURÍDICA, FINALIDADE E TUTELA DA GFIP................114

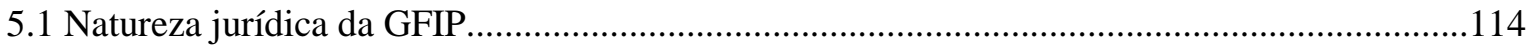

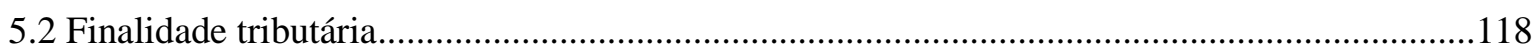

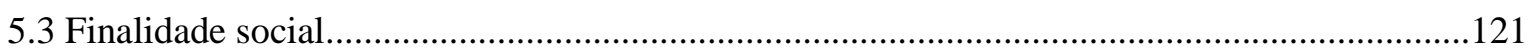

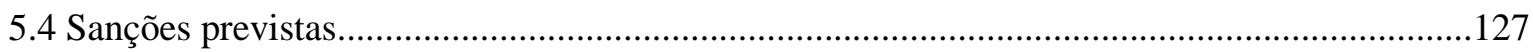

5.4.1 Sanções afetas às contribuições previdenciárias...............................................................128

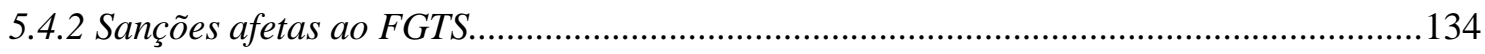

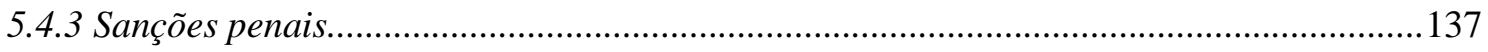

CAPÍTULO 6 - ASPECTOS RELEVANTES DO CNIS - CADASTRO NACIONAL DE

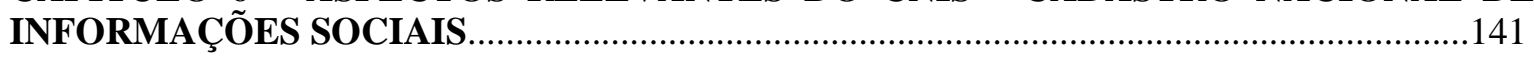

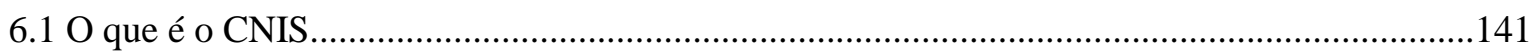

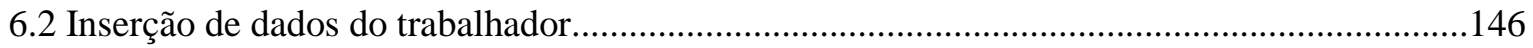

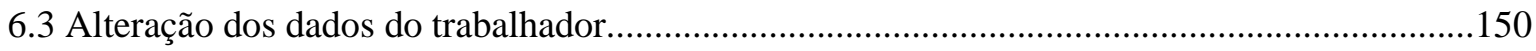

6.3.1 A alteração dos dados pelos alimentadores do CNIS.......................................................150

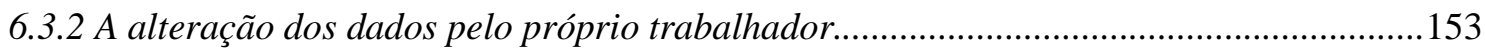

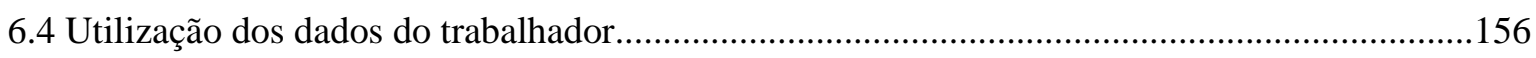

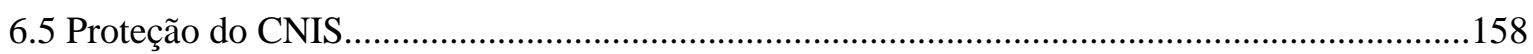

CAPÍTULO 7 - EFETIVIDADE DA TUTELA DAS INFORMAÇÕES SOCIAIS................162

7.1 Necessidade de tutela das informações sociais..........................................................................162

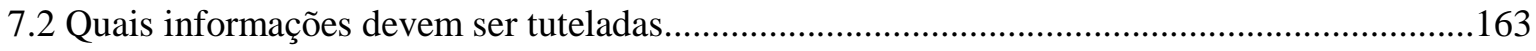

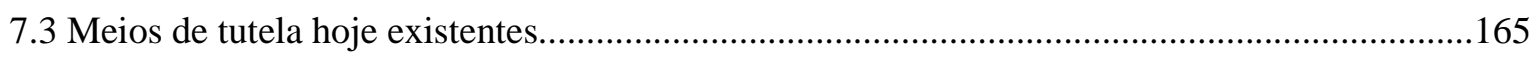

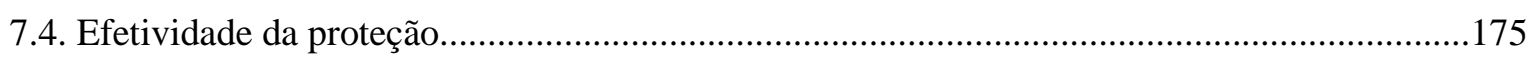

7.5 Informações sociais nos casos de sentença condenatória em reclamatória trabalhista...............178

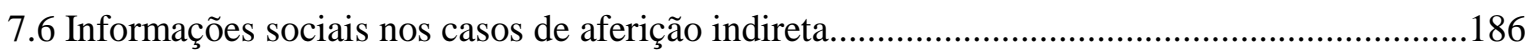

CAPÍTULO 8 - PROPOSTAS PARA UMA TUTELA EFETIVA.............................................

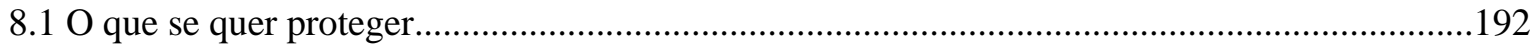

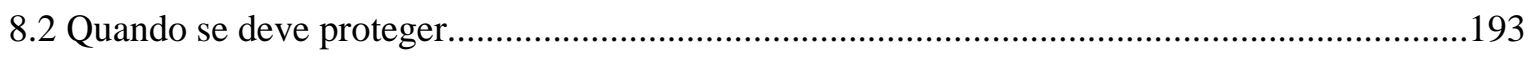

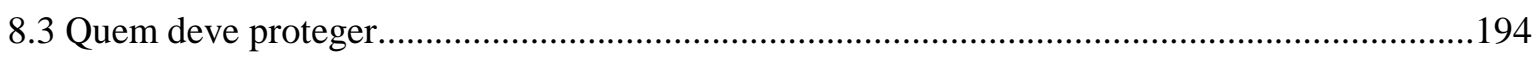

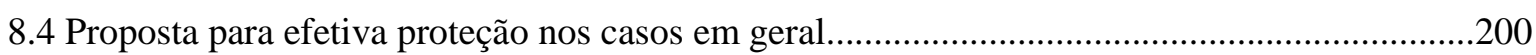

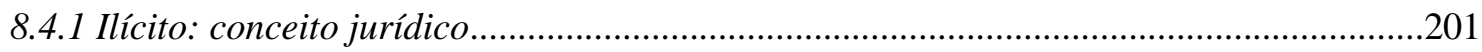




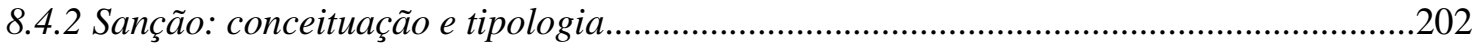

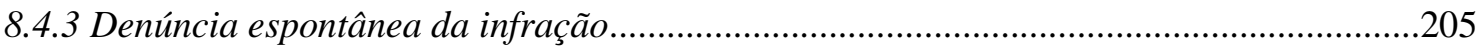

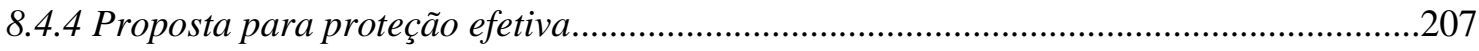

8.5 Proposta para efetiva proteção nos casos de sentença em reclamatória........................................215

8.6 Proposta para efetiva proteção nos casos de aferição indireta...................................................216

8.6.1 Proposta para efetiva proteção na aferição indireta de obra de construção civil............220

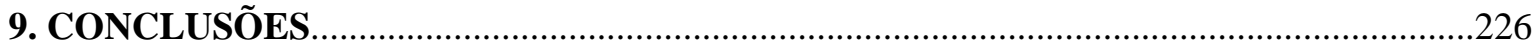

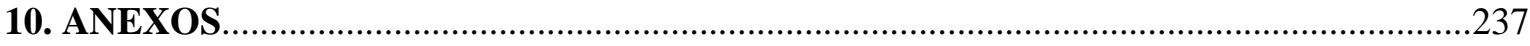

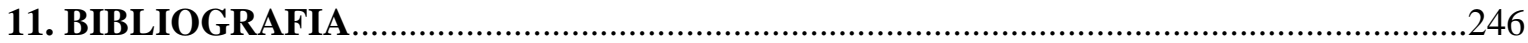




\section{1 - INTRODUÇÃo}

A Seguridade Social, verdadeira expressão do Estado de Bem-Estar Social, apoiase em três pilastras, dentre as quais a Previdência Social é a central, pois é a única que, por complementar a renda do trabalhador, efetivamente o ampara nas situações de risco social. Nesse sentido, o estudo dos direitos sociais do trabalhador se torna relevante, mormente em seus aspectos mais práticos, assim entendidos aqueles relacionados ao próprio exercício desses direitos.

Atualmente, para requerer um benefício previdenciário, um cidadão necessita agendar via telefone ou internet um atendimento em uma Agência da Previdência Social (APS) de sua escolha. No dia marcado, deverá comparecer munido de seus documentos pessoais e das comprovações que suportem o pedido no caso do benefício decorrer de motivo de saúde. Assim, o pleito será concedido com base nos dados constantes no Sistema de Benefícios da Previdência Social, alimentado pelo Cadastro Nacional de Informações Sociais (CNIS). É a chamada aposentadoria em meia hora.

Alguns anos atrás, para conseguir o benefício previdenciário, o segurado deveria apresentar toda a documentação necessária para a concessão da prestação da seguridade social que ele pleiteava. ${ }^{1}$ Porém, não é necessário nenhum esforço para se imaginar a quantidade de documentos que ele deveria possuir e a dificuldade em consegui-los, pois quem os produzia era a empresa, não o trabalhador, que, muitas vezes, havia ali trabalhado décadas antes. Existia, ainda, a enorme chance de erro na concessão do benefício, pois o cálculo do salário de benefício e, consequentemente, da renda mensal do benefício, ${ }^{2}$ era realizado a partir de documentos apresentados pelo trabalhador, que, muitas vezes, poderia apresentá-los de forma parcial e, com isso, sofreria prejuízo por falta dos valores não comprovados, embora regulares.

A alteração desse quadro ocorreu com o advento da Lei $n^{\circ} 10.403$, de 2002, que acrescentou o artigo 29-A à Lei $n^{\circ}$ 8.213/91. A partir de então, o Instituto Nacional do Seguro Social (INSS) passou a ser obrigado a calcular o valor do salário-de-benefício ${ }^{3}$ com

\footnotetext{
${ }^{1}$ Lei $\mathrm{n}^{\mathrm{o}} 10.403$, que, em janeiro de 2002, altera a Lei 8.212/91 e inverte o ônus da prova.

${ }^{2}$ Renda mensal do benefício é o valor do salário-de-benefício do segurado multiplicado pelo percentual legal do benefício em questão, conforme o art. 33 da Lei 8.213/91.

3 O cálculo do salário-de-benefício é determinado pelo artigo 29 da Lei $\mathrm{n}^{\circ}$ 8.213/91, chamada Lei de Benefícios, e leva em consideração, em apertada síntese, entre outros ditames legais, o valor do salário-decontribuição, que é calculado com base na remuneração sobre a qual incidiu a contribuição previdenciária.
} 
base nas informações constantes do CNIS, relativas às remunerações dos segurados. A mesma alteração legislativa, agora no parágrafo segundo do artigo 29-A, especifica que o segurado pode solicitar retificação dos dados registrados mediante comprovação, por documentos, das informações divergentes.

Imediatamente à alteração da lei, reconheceu-se a inversão do ônus da prova quando da concessão de um benefício previdenciário. Tal reconhecimento não poderia deixar de ocorrer, pois, como visto, antes do advento da mudança legislativa, cabia ao segurado a comprovação de sua condição previdenciária e do seu salário-de-contribuição para a obtenção do benefício pleiteado. Vemos nessa alteração, em certa medida, o reconhecimento da lei ao verdadeiro direito do cidadão ao benefício, em face do Estado Democrático de Direito.

Uma rápida passagem pela evolução histórica do CNIS esclarece a necessária integração entre os dados trabalhistas e previdenciários pertinentes à questão. Alimentado, primordialmente, por intermédio da Guia de Informações do FGTS e da Previdência Social (GFIP), o CNIS tem sua origem no intuito do Governo Federal de criar uma base de dados integrada. Para isso, foi determinada a criação do Cadastro Nacional do Trabalhador (CNT), por meio do Decreto ${ }^{\circ}$ 97.936, de 1989, na forma de consórcio entre Ministério da Previdência e Assistência Social (MPAS), Ministério do Trabalho (MTb) e Caixa Econômica Federal (CEF). Posteriormente, o CNT assumiu, conforme Lei $\mathrm{n}^{\circ}$ 8.212, de 1991, a denominação ora empregada.

A partir dessa pequena panorâmica, podemos entender que a origem do direito do trabalhador a ter seu benefício concedido com base nos dados informados concentra-se nas informações constantes da GFIP, o que ressalta a importância da guia para a efetividade do direito fundamental da aposentadoria e da proteção social quanto aos demais eventos constitucionalmente tutelados pela seguridade social. Assim, não podemos deixar de considerar o relevo desse documento.

Criada pela Lei $\mathrm{n}^{\circ}$ 9.528, de 1997, que alterou as Leis $n^{\circ} \mathrm{s} 8.212^{4}$ e 8.213 , ambas de 1991, a GFIP contém os dados dos trabalhadores que prestam serviços às pessoas físicas e jurídicas, os dados dos empregadores, o total da remuneração efetuada, os valores das contribuições previdenciárias incidentes sobre essa remuneração, além dos valores retidos pelos empregadores e devidos ao INSS e cobrados pela Secretaria da Receita Federal do Brasil (RFB), e os valores devidos ao FGTS. A GFIP dever conter, ainda, todas as

\footnotetext{
${ }^{4}$ Nos aspectos aqui abordados, a Lei n ${ }^{\circ}$ 9.528/97 introduziu o inciso IV e os parágrafos $1^{\circ}$ ao 11 , no artigo 32 da Lei ${ }^{\circ} 8.212 / 91$.
} 
informações relativas aos benefícios previdenciários concedidos aos segurados nela relacionados. Não nos cabe, por ora, esmiuçar todos os dados que se apresentam na GFIP e suas funções, pois o faremos ao longo do capítulo 4. Aqui, precisamos, sim, reter os desideratos mais importantes dessas informações e quais são as implicações causadas ao Estado e ao trabalhador pelo inadimplemento ou a incorreção desses dados.

Anteriormente à Lei $\mathrm{n}^{\circ} 11.941 / 09$, as empresas que descumprissem a obrigação de informação dos dados dos trabalhadores eram sancionadas com uma multa que, por vezes, chegava ao valor das contribuições incidentes sobre a remuneração paga a esses trabalhadores. ${ }^{5}$ Embora normalmente vultoso, esse valor da sanção poderia ser totalmente relevado pelo Fisco mediante quatro condições extremamente simples: solicitação expressa de relevação, não cometimento de situações agravantes da penalidade, não ter sido o contribuinte autuado nos últimos cinco anos e o contribuinte ter corrigido a falta, entregando a GFIP corretamente preenchida. ${ }^{6}$ Hoje, não há mais a mesma previsão, aplicando-se multa de ofício, que pode agravar o valor do tributo devido em $225 \%{ }^{7}$ irrelevável, e pequena multa pelo descumprimento da obrigação acessória, reduzível somente se corrigida a falta no prazo da intimação ou antes do procedimento de ofício. ${ }^{8}$

A alteração da sanção, sem dúvida onerosa e desestimulante do inadimplemento da obrigação, tem um efeito extremamente perverso ao trabalhador. Como dito, o rigoroso agravamento do valor do tributo, no caso de omissão de dados na GFIP, desencoraja a conduta. Mas, se por qualquer motivo a obrigação acessória do correto preenchimento e entrega da GFIP não ocorrer, essa sanção não assegura a correção da falta, pois não garante o correto preenchimento do documento de informações. Isso traz evidente prejuízo ao trabalhador, que não terá inseridos em seu cadastro seus dados relativos ao período e remuneração omitidos e assim, em caso de concessão de benefício previdenciário, ele não poderá gozar desses valores.

Não podemos deixar de realçar o enorme paradoxo que surge. O inadimplemento do obrigado, a empresa, é sancionado, e pesadamente, pois o crédito tributário é agravado com multa de ofício, que pode ser de $225 \%$. O credor, sujeito ativo da relação jurídica tributária, tem seu direito assegurado, já o devedor, sujeito passivo, foi constrangido ao pagamento. O trabalhador, por seu turno, é o sujeito para o qual, em última razão, foi

\footnotetext{
${ }^{5}$ Redação anterior à Lei ${ }^{\circ} 11.941$, do art. 32 da Lei 8212/91, $\S 4^{\circ}$ ao $7^{\circ}$.

${ }^{6}$ Art. 291 do Regulamento da Previdência Social, RPS, aprovado pelo Decreto no 3048/99.

${ }^{7}$ Art. 35-A da Lei no 8.212/91.

${ }^{8}$ Art. 32-A da Lei 8212/91.
} 
criado o tributo, uma vez que esse é destinado a financiar a Seguridade Social, e essa existe para suprir as necessidades do cidadão nos casos determinados pela Constituição. Porém, ele é o único a quem o atual sistema não protege, já que continua sem ter seus dados inseridos no sistema, mesmo depois de todos os outros atores terem cumprido suas obrigações. Sinteticamente, nesses casos, não há o povoamento dos dados do trabalhador: o Fisco age e autua o inadimplente, o qual arca com a autuação por meio do pagamento da multa. O Fisco arrecada, porém o trabalhador continua sem ter seus dados inseridos no sistema, ainda que as demais partes já tenham adimplido suas prestações.

Tal estado da legislação retira do segurado todo o ganho obtido com a chamada inversão do ônus da prova, já que ele não poderá ter garantia de que todos os dados necessários à concessão dos benefícios previdenciários constam de seu cadastro. A gravidade disso é tamanha que faz parecer mais benéfica a situação anterior, em que o trabalhador sabia de antemão que competia a ele fazer prova do seu pleito. Na situação atual, são usados os dados que constam do sistema, os quais não necessariamente correspondem à realidade do requerente. O trabalhador crê que o sistema está corretamente alimentado, o que pode não ocorrer mesmo após a ação fiscal tendente a verificar o cumprimento das obrigações previdenciárias.

Do exposto, exsurge a dupla finalidade da GFIP abastecer o banco de dados de informações sociais dos trabalhadores e de permitir o controle da arrecadação e da fiscalização das contribuições previdenciárias e dos recolhimentos fundiários.

Nesse ponto reside o enfoque do presente estudo. Como se deve tutelar eficazmente os dois desideratos do documento analisado? A legislação hoje existente apresenta essa característica? Em outros termos, a tutela das duas funções da GFIP é obtida pela legislação de proteção, assim entendida a medida sancionatória nela prevista, ou existe uma prevalência de uma finalidade sobre a outra? Se existe, essa prevalência é adequada?

Além desse prisma, pretendemos abordar, no caso da insuficiência da tutela legalmente prevista para o descumprimento das informações prestadas na GFIP quanto às finalidades sociais do documento, se cabe ao Estado ou a um outro ente suprir a lacuna de informações causada pelo inadimplemento da obrigação legal. Também vemos a necessidade de discutir a tutela do trabalhador nos casos específicos, porém abundantes, de constituição do crédito tributário previdenciário por aferição indireta de contribuição previdenciária. 
Tais situações, é sabido, acontecem quando o Fisco não tem como apurar, comprovadamente, a quantificação do fato gerador ocorrido. Um exemplo comum de constituição de crédito tributário previdenciário por aferição indireta se dá em obra de

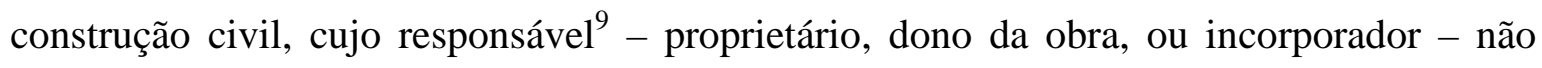
possui escrituração contábil regular e formal. Esse inadimplemento de obrigação acessória $^{10}$ não impede, como visto, a regular constituição do crédito tributário, mas obriga que se faça por aferição indireta, ${ }^{11}$ que, como é cediço, não obrigou a verificação da remuneração dos trabalhadores e nem a identificação daqueles que trabalharam na obra.

Novamente, tangenciamos a questão que nos motiva a empreender o presente estudo. $\mathrm{O}$ resultado da atividade fiscal é obtido, ou seja, o crédito tributário previdenciário é constituído, transforma-se em recursos financeiros, abastecendo os cofres da autarquia previdenciária. Porém, o que ocorre com o destinatário desses recursos, o credor do benefício da seguridade? Com aquele trabalhador que, com seu esforço, erigiu a obra de construção civil? Infelizmente, não aproveita os recursos, pois não há como se imputar as remunerações arbitradas àqueles que trabalharam na obra objeto da aferição, em razão da ausência de previsão legal.

Por fim, não poderemos deixar de examinar a questão das informações previdenciárias quando da sentença proferida em reclamatória trabalhista, na qual há execução de ofício das contribuições previdenciárias incidentes sobre a condenação resultante da ação proposta. ${ }^{12}$ Sabe-se da efetividade dessa execução, a qual gera efeitos importantes sobre a arrecadação das contribuições, mas se sabe também do praticamente inexistente cumprimento da obrigação de entrega da GFIP relativa a essa sentença trabalhista. Por óbvio, não se estendem os efeitos da condenação aos benefícios previdenciários aos quais o trabalhador tem direito em razão dessa sentença, seja na acepção de valores de remuneração reconhecidos, seja no registro do vínculo criado por força da decisão judicial.

Das colocações anteriores, podemos verificar que, em se tratando de direito previdenciário, a ótica do custeio parece prevalecer sobre a perspectiva do benefício. Seria

\footnotetext{
${ }^{9}$ Cf. Art. 33, § $4^{\text {o }}$, da Lei ${ }^{\circ}$ 8. 212/91

${ }^{10} \mathrm{O}$ artigo 225, §§ $9^{\circ}$ e 13, do Regulamento da Previdência Social, RPS, aprovado pelo Decreto no 3.048/99, imputa aos responsáveis pela obra essas obrigações.

${ }^{11}$ O Código Tributário Nacional trata da aferição indireta no artigo 148, denominando arbitramento os casos nos quais o Fisco não pode, pelos motivos ali elencados, quantificar o fato gerador ocorrido. Já a Lei $\mathrm{n}^{\circ}$ $8.212 / 91$ prevê a aferição indireta no artigo $33, \S 3^{\circ}$.

${ }^{12} \mathrm{Cf}$. Art. 114, inciso VIII, da Constituição Federal.
} 
aceitável se essa constatação contemplasse uma visão de equilíbrio atuarial e financeiro do sistema. Porém, nada existe que nos permita essa conclusão.

A atual disposição legal acerca do tema, que será esmiuçada ao longo do trabalho, é enviesada somente no sentido da arrecadação sem a contrapartida social necessária. Afirmamos isso, pois não há o que garanta o direito do trabalhador, o qual contibuiu para o sistema previdenciário com a própria contribuição ou com a incidente sobre a remuneração por ele percebida, e que, por disposição constitucional, recai sobre quem usufruiu do resultado do seu esforço, ou seja, a empresa ou o a ela equiparado.

Apresenta-se, ao permanecer a atual legislação, um fundado risco de que o banco de dados da previdência social se torne, cada vez mais, deficiente no tocante a exatidão dos dados relativos à remuneração dos segurados, quanto aos vínculos desses, e aos benefícios por eles recebidos, isso tudo em face da constatação dos créditos previdenciários constituídos nos quais a obrigação acessória representada pela GFIP não foi cumprida espontaneamente pelo legalmente obrigado, e não há previsão legal de sanção efetiva que garanta o seu cumprimento.

Ora, a alteração legislativa que inseriu a inversão do ônus da prova foi acolhida como uma bem-vinda revolução social para uma efetiva prestação do direito previdenciário. O INSS, deixando de exigir a comprovação daquilo que o Estado, ente eleito como o tutor dos direitos sociais constitucionais, deveria ter como informação, passou a buscar o real exercício de seu papel enfocando o favorecimento social e a concretização do direito previdenciário, um dos pilares do direito social moderno, prenunciando uma gestão que, por força da Constituição Federal, deve buscar o equilíbrio financeiro e atuarial do sistema. Mais além, a presunção relativa da existência e exatidão dos dados do segurado junto à autarquia previdenciária pode ser elidida pelo interessado, mediante a comprovação documental do alegado, consoante o disposto no $\S 2^{\circ}$ do citado artigo 29-A da Lei de Benefícios. ${ }^{13}$

Todavia, parece-nos que o intuito das alterações promovidas não se vislumbra efetivo. O retrocesso legislativo, ou mesmo normativo, causado por alterações com foco nos efeitos arrecadatórios das contribuições previdenciárias indica uma degradação dos objetivos acima apontados. A tutela dos direitos sociais deve ser - até por determinação constitucional - eficazmente constituída.

${ }^{13}$ Consoante alteração legislativa introduzida pela Lei Complementar $n^{\circ}$ 128/08. 
Desse modo, pretendemos, nesta pesquisa, levar a questão à discussão, e, por entendermos ser função do trabalho acadêmico contribuir com algumas conclusões para o aprimoramento do comando constitucional, estipular condições que favoreçam a real tutela dos direitos sociais dos trabalhadores, e por extensão, de todos os brasileiros.

Tal tarefa exige um método científico que norteie o trabalho a ser construído. A partir de um conjunto de princípios de avaliação da evidência ${ }^{14}$ serão estabelecidos enunciados e constatações. Partindo-se de uma hipótese tida como verdadeira, assumido corte metodológico, e cujo exame, portanto, não faz parte do raciocínio, extraem-se conclusões. A esse método de trabalho denomina-se dedutivo. Percorrendo-se o caminho em sentido inverso, emprega-se um processo lógico cuja conclusão proposta contém mais elementos que a amostragem inicial e certos de terem-se examinados o maior número possível de exemplares, pode-se afirmar o construído. Esse método é chamado de indutivo. Por fim, abdutivo é o método que permite a construção de uma hipótese explicativa a partir de um fato surpreendente, e para tanto se utiliza ou um ato criativo ou o instinto racional.

Pierce defende que os três métodos explicitados integram um todo coeso como etapas de investigação científica, o que nos impele à utilização de todos. ${ }^{15}$ Daremos preferência ao método dedutivo, dada a tônica do presente trabalho de partir de análises axiológicas das normas jurídicas, hipóteses que não se questionam - pois verdades extraindo-se conclusões ideais. Enfim, entendemos que o método dedutivo é um processo investigativo mais apropriado para provar o "dever ser".

Como técnicas de pesquisa, prepondera o uso da bibliográfica, com base em autores nacionais e estrangeiros, e considerando o tema proposto, julgamos necessária a pesquisa interdisciplinar, posto que nos parece inescapável a utilização do método histórico, sociológico e comparativo nas conclusões obtidas.

Estruturamos nossa análise em nove capítulos. No capítulo subsequente, apresentaremos os direitos sociais mais relacionados com nossos objetivos, o direito do trabalho e o da seguridade social. Analisando as disposições constitucionais afetas a esses dois ramos do direito, construiremos nossas bases de conhecimento necessárias para o deslinde das questões que deveremos enfrentar ao longo de nosso percurso.

\footnotetext{
${ }^{14}$ Tércio Sampaio Ferraz assim conceitua o método científico. Cf. FERRAZ, Tércio Sampaio. A ciência do direito. São Paulo: Atlas, 1980. p.11.

${ }^{15}$ PIERCE, Charles Sanders apud SANTAELlA, Lucia. Comunicação e pesquisa. São Paulo: Hacker Editores, 2001. p.123.
} 
No capítulo 3, após uma contextualização baseada na evolução histórica, estudamos o atual sistema previdenciário da Itália, da Espanha e de Portugal, países de forte influência cultural, étnica e jurídica no Brasil. Tal estudo visa ampliar nosso objeto de análise, no sentido do conhecimento de outras práticas adotadas por ordenamentos jurídicos similares, permitindo uma maior capacidade propositiva e conclusiva.

A partir do capítulo 4, iniciamos um aprofundamento nos institutos, na legislação e na organização do sistema previdenciário brasileiros. Nele, perscrutamos a GFIP, verdadeiro veículo da implementação dos direitos sociais do trabalhador, a qual deve ser preenchida mensalmente pela empresa e transmitida para a base de dados das informações sociais do trabalhador.

A natureza jurídica da GFIP, suas finalidades e a previsão legislativa de proteção ao seu conteúdo são analisadas no capítulo 5 , que tem por objetivo firmar as premissas sobre a utilidade e objetivos do documento e a efetividade da tutela legislativa.

A GFIP, como mencionado, serve de meio de transporte das informações sociais dos trabalhadores, inserindo - de maneira sistêmica - esses dados no CNIS, que concentra as informações necessárias à concessão dos benefícios sociais do trabalhador. No capítulo 6 conheceremos os aspectos relevantes do CNIS.

Amparados pelo conhecimento do modo pelo qual o segurado da Previdência Social acessa os benefícios sociais que o direito positivo lhe assegura, estudaremos no capítulo 7 se há proteção efetiva às informações que garantem ao trabalhador o gozo desses seus direitos, o que significa questionar se existe proteção aos próprios direitos sociais do trabalhador.

No capítulo 8, apresentaremos nossas propostas para uma proteção efetiva das informações sociais, ou seja, uma tutela eficaz do acesso do trabalhador aos benefícios sociais.

Em seguida, apresentaremos nossas conclusões, esperando contribuir para a solução de um problema social criado pela desatenção ou desconhecimento do legislador sobre o funcionamento do sistema de concessão dos benefícios previdenciários, hoje fortemente embasado nas informações prestadas pelo empregador, assim entendido a empresa ou o a ela equiparado, que contrata serviços prestados por pessoa física, sob qualquer forma de contrato.

Tal sistema, que se louva pelo funcionamento exemplar quando todos os envolvidos cumprem suas obrigações, não está concebido para atingir seus objetivos no 
caso do inadimplemento da empresa do dever de prestar as informações sociais relativas aos seus trabalhadores. Neste caso, há inegável injustiça, pois mesmo após a atuação do Estado, por meio de seus agentes fiscais, o trabalhador não terá seus direitos previdenciários corretamente concedidos.

Entendemos ser possível, com a adoção e necessário aperfeiçoamento das propostas modestamente formuladas, a reversão deste quadro contrário ao Estado do Bem-Estar Social esculpido na Carta Magna. 


\section{CAPÍTULO 2 - DIREITOS SOCIAIS DO TRABALHADOR}

Inúmeros são os conceitos de direitos humanos, tantos foram os autores de renomada que já escreveram sobre o tema. Dentre todos, escolhemos, para iniciar nosso capítulo, Goffredo Telles Junior, de saudosa memória, que ensina:

No momento em que a fruição dos bens soberanos é assegurada por lei,
emergem Direitos Subjetivos especiais, que são proclamados DIREITOS
HUMANOS ou DIREITOS DO HOMEM. É evidente que todos os
Direitos Subjetivos são direitos humanos. São direitos do ser humano.
Mas as expressões consagradas de "Direitos Humanos" e "Direitos do
Homem" foram reservadas para designar, especificamente, aqueles
Direitos Subjetivos que se definem nos seguintes termos: "permissões
jurídicas para a fruição de bens soberanos'. ${ }^{16}$

Longe do brilhantismo do Professor Goffredo, nós, ao conceituarmos direitos humanos, tendo por base o senso comum, diríamos serem eles o conjunto de direitos essenciais da pessoa humana e os relativos à sua dignidade. Vladmir Silveria entende que definição desta estirpe, além de tautológica, depende do conceito de dignidade da pessoa humana, que também padece de amplitude conceitual, impedindo seu uso científico, pois o emprego do termo 'direitos humanos' pode gerar interpretações contrárias à validade contida no sentido pretendido da expressão. ${ }^{17}$

Em que pese a correção do raciocínio, parte da doutrina caminha em sentido diverso, emprestando à amplitude conceitual o mérito do abrigo e, portanto, da proteção, de uma gama maior de dispositivos direcionados à tutela dos direitos de defesa do indivíduo. Apoiando-se na Carta da República de 1988, que utiliza, em seu Título II, a expressão direitos fundamentais, David Araújo e Serrano Nunes apontam "a sinonímia entre as expressões liberdades públicas, direitos humanos, direitos subjetivos públicos e direitos fundamentais." 18

Dentre todas as acepções, José Afonso da Silva entende ser a denominação direitos fundamentais a mais adequada, pois, além de referir-se a princípios que resumem a concepção de mundo e informam a ideologia política de cada ordenamento jurídico, é

\footnotetext{
${ }^{16}$ TELLES Jr., Goffredo. Introdução na Ciência do Direito. São Paulo: Saraiva, 2001. p.343.

${ }^{17}$ SILVEIRA, Vladmir Oliveira da; ROCASOLANO, Maria Mendez. DIREITOS HUMANOS: Conceitos, Significados e Funções. São Paulo: Saraiva, 2010. p. 203.

${ }_{18}$ ARAÚJO, Luiz Alberto David; NUNES Jr., Vidal Serrano. Curso de Direito Constitucional. São Paulo: Saraiva, 1999. p. 65.
} 
reservada para designar, dentro do direito positivo, aquelas prerrogativas e instituições que são concretizadas pelo ordenamento como garantias de uma convivência digna, livre e igualitária. ${ }^{19}$ Explicitando sua assertiva, Afonso da Silva nos recorda que no adjetivo 'fundamentais' há a indicação de que se trata de situações jurídicas sem as quais a pessoa humana não se realiza, não convive e, por vezes, não sobrevive.

Sendo base e pedra angular do Estado Democrático de Direito, os direitos fundamentais são a "personificação e positivação constitucional de determinados valores básicos" ${ }^{20}$ e integram o núcleo substancial da ordem normativa. ${ }^{21}$ A Carta Cidadã, em seu Título II, Dos Direitos e Garantias Fundamentais, explicita ser esse o gênero que engloba os Direitos Individuais e Coletivos e os Direitos Sociais, que são o foco de nosso estudo, além da nacionalidade e dos direitos políticos.

Os direitos sociais integram, na já consagrada classificação das 'dimensões ${ }^{, 22}$ dos direitos fundamentais, os direitos de segunda dimensão, ${ }^{23}$ no sentido da atuação estatal como garantidora das condições de desenvolvimento do cidadão e da vida em sociedade, induzindo os investimentos de forma a propiciar um crescimento do indivíduo que permita sua inserção no modelo social como agente produtivo, agregador e partícipe do próprio Estado. Tais objetivos só poderão ser alcançados por todos a partir de um sistema educacional de acesso universal, de qualidade e preparado para a formação integral do cidadão e da cidadã.

Inegável, nesse sentido, a necessidade de amparo à saúde, também de acesso universal, tanto em seus aspectos preventivos, mormente no atual nível de desenvolvimento das ciências médicas, quanto nos aspectos de recuperação e cura.

${ }^{19}$ SILVA, José Afonso da. Curso de direito constitucional positivo. $16^{\text {a }}$ ed., São Paulo: Malheiros, 1999. p.182.

${ }^{20}$ FRANÇA, Giselle de Amaro e. O Poder Judiciário e as Políticas Públicas Previdenciárias. São Paulo: LTr, 2011. p. 45.

${ }^{21}$ SARLET, Ingo. A eficácia dos direitos fundamentais. $9^{a}$ ed. Porto Alegre: Livraria do Advogado, 2007. p. 70. apud FRANÇA, Giselle de Amaro e. ob. cit. p. 45.

${ }^{22}$ Por dimensões dos direitos fundamentais, podemos entender a medida da acumulação desses direitos, isto é, o quantum que se acrescenta aos direitos já consagrados. Usa-se, também no mesmo sentido, a expressão 'geração de direitos'.

${ }^{23} \mathrm{Em}$ apertada síntese, podemos entender a primeira dimensão, ou geração, dos direitos fundamentais, como sendo aquela que resguarda a esfera de proteção dos direitos do indivíduo contra o Estado, ou seja, o gozo das liberdades fundamentais, o não agir do Estado. A segunda dimensão contempla os direitos sociais, os econômicos e os culturais, ou seja, os relacionados ao bem-estar da coletividade, englobando o direito à educação, saúde, moradia, previdência social, trabalho etc. Na terceira dimensão, encontraríamos bens e interesses difusos, como o meio ambiente saudável, a paz mundial, o desenvolvimento economicamente sustentável, a fraternidade, entre outros. Bobbio já antevia o prenúncio de uma quarta geração, relacionada à defesa do patrimônio genético, como segurança, ou limites às pesquisas biológicas. (Cf. BELTRAN, Ari Possidonio. Direito do trabalho e direitos fundamentais. São Paulo: LTr, 2002.). 
Impossível se pensar em saúde, no sentido do conceito da Organização Mundial de Saúde, ${ }^{24}$ sem a garantia de moradia, de lazer, de segurança, de proteção à maternidade, de assistência aos desamparados. Todo o exposto faz parte do desejo do Constituinte de 1988, e o Estado Brasileiro, segundo o artigo $6^{\circ}$ da Constituição da República, deve assegurar, nos termos aqui expostos e delineados pela lei, o acesso aos bens mencionados.

Porém, nem só os direitos à educação, à saúde e aos demais mencionados constam do artigo $6^{\circ}$ da Carta. Dois, entre os principais em nossa concepção, deixamos para uma análise apartada, trabalho e previdência social. Em primeiro, o direito ao trabalho, de inegável interesse coletivo, pois, além de permitir ao cidadão o seu sustento e o de sua família, agrega dignidade pela capacidade de geração de renda e orgulho pela capacidade de domínio e controle das ações pelo indivíduo.

O trabalho, ao mesmo tempo que gera riqueza para o país, desonera o Estado do custo decorrente do assistencialismo que seria necessário na ausência de renda própria. Por todo o exposto, e cumprindo os ditames da Constituição, cabe ao Estado fomentar o trabalho, induzindo a economia no sentido da geração de postos de trabalho para toda a população economicamente ativa.

Justamente no sentido de proteção da capacidade de trabalho do indivíduo, como seguro às vicissitudes da vida laboral, surge a previdência social. Essa supre, por meio das prestações previstas em lei, os eventos futuros e incertos que podem vir a impedir, provisória ou definitivamente, a geração de renda pelo trabalho.

Neste capítulo, analisaremos as disposições constitucionais sobre o trabalho, a seguridade social e a previdência social, e quanto a esta, em especial, como se consolida o acesso aos benefícios.

\subsection{Direito Constitucional do Trabalho}

A evolução do direito ao longo da história da humanidade fascina a todos que se debrucem sobre a questão. No entanto, poucos institutos sociais e jurídicos alternam tanto sua valoração como o trabalho. O termo, que tem sua origem etimológica no latim,

\footnotetext{
${ }^{24}$ A OMS define saúde como sendo "o estado dinâmico de completo bem-estar físico, mental, espiritual e social $e$ não apenas a ausência de doença ou enfermidade" (disponível em: www.almamix.pt/index.php?option...oms-saude consultado em 11/12/2012 às 11:22hs.)
} 
significa "martirizar com o tripalium", um instrumento de tortura composto de três paus. ${ }^{25}$ Tal acepção demonstra que o trabalho, nos primórdios da civilização ocidental, era considerado um castigo e renegado como atividade, tanto que cabia aos escravos o desenvolvimento das atividades braçais, o esforço necessário para a elaboração de qualquer tarefa, exceto as intelectuais, essas sim reservadas aos cidadãos. Com o advento do cristianismo, o trabalho, que até então desfrutava de conceitos negativos, mais ou menos desprezíveis conforme o contexto, passa a ter uma consideração mais digna, pois a fadiga resultante do desenvolvimento do trabalho purgava os pecados daquele que empreendia alguma atividade. Finalmente, com o Renascimento, o trabalho passa a ser louvado como atuação livre e racional do homem e, nessa dimensão, verdadeira essência humana. ${ }^{26}$

Durante os séculos seguintes alternam-se os meios de obtenção das tarefas. Em alguns períodos, isso se dava por meio do trabalho escravo, e em outros por meio de atividades artesanais e rurais, passando pelo período das corporações de ofício até chegarmos ao advento da Revolução Industrial e do Estado Liberal.

Nesse momento histórico, surge o Direito do Trabalho como tentativa de pacificação da questão social. Para isso, o ramo do direito estrutura-se sobre uma base normativa protetiva como forma de o indivíduo enfrentar as organizações de Capital. Sobre essa estruturação, esclarece Nelson Mannrich:

Em torno dele se consolidou um conjunto de normas destinadas a introduzir uma desigualdade jurídica a fim de superar as desigualdades econômicas, viabilizando a exploração do trabalho humano, livre e por conta alheia, pelo sistema capitalista, mediante contrato de trabalho. ${ }^{27}$

Mannrich sustenta a afirmação da pacificação social por meio da positivação das normas trabalhista, ao recordar que "numa primeira fase, marcada pela compaixão social (...), a proteção privilegiou a mulher e o menor", o que impediu a exploração das "meiasforças dóceis" que grassava nessa época, gerando revolta social em função da jornada desumana, da insalubridade e dos salários ínfimos. O Direito do Trabalho surge, assim, como um conjunto de normas imperativas, ou seja, impostas pelo Estado, as quais

\footnotetext{
${ }^{25}$ Cf. BARROS, Alice Monteiro de. Curso de Direito do Trabalho. $2^{\text {a }}$ ed. São Paulo: LTr, 2006. p. 49.

${ }^{26}$ Cf. BARROS, Alice Monteiro de. Curso de Direito do Trabalho. $2^{\mathrm{a}}$ ed. São Paulo: LTr, 2006. p. 50.

${ }^{27}$ MANNRICH, Nelson. Tendências Atuais Relativas ao Âmbito Pessoal do Direito do Trabalho em Portugal, Espanha e Brasil. in Revista da Academia Nacional do Direito do Trabalho. Ano XVI, nº 16. São Paulo: LTr, 2008. p. 50.
} 
estabelecem limites objetivos aos excessos do liberalismo econômico e, por isso, revela-se como um pacificador social.

No Brasil, os reflexos das questões trabalhistas apontadas ecoam com atrasos. Para compreender o direito social brasileiro, Cesarino Jr. propôs uma divisão distinta, a qual pretendemos seguir a partir da análise das Constituições. A história desse ramo do direito poderia ser dividida em: período pré-histórico (1500 a 1888); período capitalista (1888 a 1930); período socialista (1930 a 1934); período social-democrático (1934 a 1937); corporativo (1937 a 1946); progressista (1946 a 1964) e, finalmente, período revisionista (de 1964 aos dias atuais). ${ }^{28}$

Segundo o autor, a legislação social brasileira começou após 1930. Isso, entretanto, não significa que antes não existiam leis sobre o trabalho. Havia-as, porém esparsamente, o que não permite identificar uma legislação social. Em verdade, se encontram apenas disposições legislativas fragmentárias. A Constituição do Império, por exemplo, se limitava a assegurar a liberdade de trabalho em seu artigo 179. Proclamada a República, em 1889, não houve grande preocupação com o problema das leis sobre o trabalho, cingindo-se a Constituição de 1891 a manter a liberdade de trabalho, já assegurada na Carta anterior. De relevante, encontramos em 1919 uma lei sobre acidentes do trabalho; e em 1923, a famosa Lei Elói Chaves, que disciplina a estabilidade no emprego dos ferroviários que contassem com 10 ou mais anos de serviço na mesma ferrovia.

O período socialista (1930 a 1934) é caracterizado pela criação de numerosas leis trabalhistas, que alteram completamente a maneira de se encarar a questão social, mormente ao se recordar que no período dito capitalista esta questão era considerada 'caso de polícia'. Em 1930, cria-se o Ministério do Trabalho, o que é apontado por alguns como sendo o marco do aparecimento do Direito do Trabalho no Brasil. ${ }^{29} \mathrm{O}$ fato histórico marcante para o período socialista é a Revolução de 1930, com a instituição do Governo Provisório de Getúlio Vargas, que toma como uma de suas primeiras medidas a publicação do Decreto $\mathrm{n}^{\circ}$ 19.842, no qual constam várias medidas de proteção do trabalhador. Em 1931, com o Decreto n 19.770, o Governo Provisório regula a sindicalização, adotando um nítido viés corporativista, o que nesse segmento denota o intervencionismo estatal no movimento sindical.

\footnotetext{
${ }^{28}$ Cf. CESARINO JR, A. F. Direito Social Brasileiro. 6a ed. São Paulo: Editora Saraiva, 1970. p. 79.

${ }^{29}$ Cf. BARROS, Alice Monteiro de. Curso de Direito do Trabalho. $2^{\text {a }}$ ed. São Paulo: LTr, 2006. p. 49. BELTRAN, Ari Possidonio. Direito do Trabalho e Direitos Fundamentais. São Paulo: LTr, 2002. p. 45
} 
O período social-democrático, assim denominado graças à inspiração da social democracia sobre o Poder Constituinte, representa um breve intervalo do intervencionismo estatal no direito do trabalho, mesmo que nos aspectos formais. A Carta de 1934, a primeira a tratar da ordem econômica e social, cria a Justiça do Trabalho; institui o saláriomínimo; ${ }^{30}$ dispõe sobre jornada de trabalho; férias; repouso hebdomadário; indenização por dispensa sem justa causa; assistência médica e sanitária ao trabalhador e à gestante; proíbe a discriminação salarial por motivo de sexo, raça, religião, idade e estado civil; e foi a única Constituição Brasileira a prever a pluralidade sindical, emprestando ainda autonomia aos sindicatos. ${ }^{31} \mathrm{O}$ período denominado socialista, além dos dispositivos da Constituição de 34, também foi palco de surgimento de alguns trabalhos doutrinários sobre a legislação. A jurisprudência, por sua vez, é copiosa, mas ainda não se pode verificar uma atuação de relevo na elaboração do novo direito. ${ }^{32}$

Marco diferenciador do período social-democrata para o corporativista, na classificação de Cesarino Jr., a Constituição de 1937 diz, em seu artigo 136, que o trabalho é um dever social, garantindo a todos o direito de subsistir mediante seu trabalho honesto, bem que o Estado deve proteger. Além de continuar assegurando diversos direitos trabalhistas já concedidos pelo Texto de 1934, essa Constituição os amplia, ${ }^{33}$ como se pode identificar na determinação de uma remuneração superior pelo trabalho noturno, na ampliação do repouso para os feriados e dias santos e na explicitação das garantias da continuidade do contrato de trabalho no caso de sucessão trabalhista.

Apesar desses aspectos, a Carta de 1937, sob a tremenda influência do regime político italiano e de sua Carta del Lavoro, adota o intervencionismo estatal, típico do corporativismo peninsular, que sobrevive até hoje em nosso direito coletivo, mesmo com o advento das Constituições de 1946 e de 1988, ambas reconhecidamente democráticas. Nesse sentido, resta a lição de Siqueira Neto:

as marcas desta influência, consumada e consolidada entre 30 e 37, foram de tal ordem, que as características fundamentais de controle e ou

\footnotetext{
${ }^{30}$ A Carta de 1934 dispõe em seu artigo 121 que a legislação do trabalho observará os preceitos ali elencados, dos quais destacamos os principais.

31 Ari Beltran aponta que a autonomia emprestada aos sindicatos era relativa, uma vez que exigia-se a presença de um delegado do Ministério do Trabalho nas assembleias sindicais. (BELTRAN, Ari Possidonio. Direito do Trabalho e Direitos Fundamentais. São Paulo: LTr, 2002. p. 46).

${ }^{32}$ Cf. CESARINO JR, A. F. Direito Social Brasileiro. 6a ed. São Paulo: Editora Saraiva, 1970. p. 81.

${ }^{33}$ Cesarino Jr, ao comparar as Constituições de 34 e 37 quanto ao seu conteúdo de direito do trabalho, afirma "confrontando os dois estatutos, vê-se que a Constituição de 37 foi muito mais adiantada que a de 1934 e, sobretudo, tornou precisos certos textos cujo interpretação já havia dado lugar a dúvida”. CESARINO JR, A. F. ob. cit. p. 83.
} 
intervenção sobre o Direito do Trabalho brasileiro, mesmo com a ocorrência de processos constituintes em marcos políticos democratizantes ou democráticos (1946 e 1988), foram mantidas e permanecem produzindo efeitos até os dias atuais. ${ }^{34}$

Pela relevância, mesmo que não pertencente ao âmbito constitucional, não podemos deixar de apontar o advento do Decreto-lei $\mathrm{n}^{\circ} 5.452$, de $1^{\circ}$ de maio de 1943 , que traz ao ordenamento jurídico a Consolidação das Leis do Trabalho, representante de inegável avanço, ao menos quanto ao trabalho, aglutinando em um único texto as leis trabalhistas esparsas e de marcante influência corporativista.

A Constituição de 46, como mencionado, retoma as diretrizes democráticas de 1934 e apresenta inovações importantes ${ }^{35}$ não só no tocante ao direito do trabalho, como também aos direitos individuais. Nela, se reconheceu o direito à livre associação para fins lícitos e se determinou, em se tratando da organização da ordem econômica, que essa deve assentar-se sobre os princípios da justiça social, conciliando a liberdade de iniciativa com a valorização do trabalho humano.

Os direitos trabalhistas constantes no artigo 157, em seus diversos incisos, versam sobre participação dos empregados nos lucros das empresas; salário-mínimo familiar; higiene e segurança do trabalho; obrigatoriedade de seguro acidente do trabalho instituído pelo empregador; estabilidade na empresa ou trabalho rural e indenização ao trabalhador dispensado nos termo da lei; e licença remunerada para a gestante. Finalmente, no artigo 158, reconheceu o direito de greve. Alice Monteiro de Barros ${ }^{36}$ aponta a relevância da determinação, pela Carta de 1946, da integração da Justiça do Trabalho ao Poder Judiciário, uma vez que, sob a égide do ordenamento de 1937, a Justiça Laboral era um órgão administrativo.

O movimento militar de 1964 outorga poderes constituintes ao Congresso Nacional e esse, em 24 de janeiro de 1967, aprova nova Constituição. Não obstante a restrição ao direito de greve dos servidores públicos e o início do processo de eliminação da estabilidade decenal, que se implementa com a criação do regime do Fundo de Garantia por Tempo de Serviço como opção do trabalhador, houve manutenção da ampla maioria

\footnotetext{
${ }^{34}$ SIQUEIRA NETO, José Francisco. Direito do Trabalho e Democracia - Apontamentos e Pareceres. São Paulo: LTr, 1996. p. 195. apud BELTRAN, Ari Possidonio. Direito do Trabalho e Direitos Fundamentais. São Paulo: LTr, 2002. p.47.

35 Ari Beltran assevera que " do ponto de vista das relações sociais, a Constituição Federal de 18 de setembro de 1946 nada ficava a dever às mais avançadas do mundo” ( BELTRAN, Ari Possidonio. ob.cit. p. 48).

${ }^{36}$ BARROS, Alice Monteiro de. Curso de direito do trabalho. $2^{\text {a }}$ ed., São Paulo: LTr, 2006. p. 71.
} 
dos direitos trabalhistas assegurados pela Carta de 1946, até com alguma ampliação que exemplificamos pela criação do salário-família para os dependentes do trabalhador. Em que pese o autoritarismo que encerrava a Emenda Constitucional $n^{\circ} 1$ de 1969, esse não impactou nos direitos trabalhistas, exceto pela transferência de competência para Justiça Federal para conhecer e decidir sobre os litígios envolvendo os servidores públicos e a União.

Saindo do período de exceção, após intensa mobilização popular consubstanciada pelo Movimento Diretas Já, foi eleita a Assembleia Nacional Constituinte, em 1986, e dois anos depois, em 05 de outubro de 1988, foi promulgada a Constituição da República Federativa do Brasil, denominada Constituição Cidadã pelo Presidente da Assembleia Nacional Constituinte, Deputado Ulysses Guimarães.

Lastreada na dignidade da pessoa humana e nos valores sociais do trabalho, a nova carta constitucional é fértil em disposições sociais, inclusive quanto aos direitos trabalhistas contidos nos trinta e quatro incisos do artigo $7^{\circ}$. Passemos a examiná-los inspirados no modelo didático de José Afonso da Silva, ${ }^{37}$ que separa a análise em direitos: relativos ao trabalho e garantia de emprego; sobre as condições de trabalho; relativos ao salário; afetos ao repouso e inatividade; proteção ao trabalhador e aos seus dependentes; referentes à participação na empresa; e, por fim, os direitos coletivos do trabalho.

O direito ao trabalho e garantia de emprego decorre de uma leitura sistêmica da Carta Magna, que se inicia com a disposição do artigo $6^{\circ}$, o qual atribui ao trabalho natureza de direito social e, a esse último, o caráter de um dos fundamentos da República. As disposições do artigo 170 e do artigo 193 determinam, respectivamente, que a ordem econômica e a que a ordem social também estão fundamentadas na valorização social do trabalho. Sob este feixe interpretativo se aplica a disposição do inciso I, segundo o qual o direito ao trabalho se consubstancia por uma relação de emprego protegida contra despedida arbitrária ou sem justa causa, nos termos de lei complementar, que preverá indenização compensatória, dentre outros direitos.

O valor social do trabalho é reforçado pela proteção contra o desemprego involuntário, representada pelo seguro-desemprego (inciso II do artigo $7^{\circ}$ ), especialmente se pensarmos que o trabalhador, quando desempregado, deverá empreender esforços na busca por outro posto de trabalho.

\footnotetext{
${ }^{37}$ SILVA, José Afonso da. Curso de Direito Constitucional Positivo. 16a ed. São Paulo: Malheiros, 1999. p. 292.
} 
A dedicação ao empregador por todo o tempo do contrato de trabalho é objeto de constituição de um fundo de garantia por tempo de serviço, ${ }^{38}$ constituído às expensas do empregador. Com isso, constitui-se a garantia do emprego, uma vez que sobre o valor depositado é calculada a indenização no caso de dispensa imotivada. ${ }^{39}$ Sendo necessária a ruptura contratual, o inciso XXI, recentemente regulamentado, ${ }^{40}$ ainda como medida protetiva, prevê que o empregador comunique previamente o trabalhador sobre a cessação do contrato de trabalho, por meio de um aviso prévio que pode perdurar por 90 dias, sendo no mínimo de 30 dias.

Os direitos sobre as condições de trabalho, verdadeira expressão do princípio da dignidade humana no âmbito das relações laborais, implementam-se, por vezes, de forma individual, subjetiva. Porém, na maioria dos casos, é por meio das posturas coletivas, afetas ao meio ambiente do trabalho, que se garantem as dignas condições de trabalho, sem olvidar a necessária edição de normas de saúde, higiene e segurança do trabalho para redução dos riscos inerentes às atividades (inciso XXII).

O Texto Fundamental reconhece a importância da contratação coletiva e prevê a autonomia sindical, o direito de greve e cria as bases para o desenvolvimento das negociações coletivas por meio das convenções e acordos coletivos. Aos últimos é emprestada tamanha relevância que é possível que acordos e convenções disponham até sobre redução de jornada e de salário, turnos de revezamento e compensação de horário. ${ }^{41}$

No tocante ao salário, sinalagma do contrato de trabalho, inúmeras são as disposições constitucionais. De plano, devemos ressaltar a proteção ao salário e total repulsa à retenção desse por parte do empregador, tendo o Constituinte criminalizado tal conduta (inciso X). O valor do salário deve ter tal monta que seja suficiente para manutenção do trabalhador e de sua família e nunca inferior a esse montante (inciso IV), isso mesmo quando o trabalhador perceba remuneração variável (inciso VII); e mais: as categorias profissionais poderão acordar sobre um piso salarial compatível com a extensão e complexidade do trabalho (inc. V), ressalvado que não poderá haver diferença de salários, de exercício de funções e de critério de admissão por motivo de sexo, idade, cor ou estado civil (inciso XXX), ao que devemos acrescer a proibição de qualquer

\footnotetext{
${ }^{38}$ Constituição Federal, artigo $7^{\circ}$, inciso III.

39 Alice de Barros entende que no atual estágio de nossa legislação não há tutela quanto à ocupação (BARROS, Alice Monteiro de. Curso de Direito do Trabalho. $2^{\mathrm{a}}$ ed. São Paulo: LTr, 2006. p.936). No sentido da garantia de emprego pela onerosidade da dispensa imotivada, SUSSEKIND, Arnaldo. Curso de Direito do Trabalho. $3^{\text {a }}$ ed. Rio de Janeiro: Renovar, 2010. p. 390.

${ }^{40}$ Lei $\mathrm{n}^{\mathrm{o}} 12.506$, de 11 de outubro de 2011 , regulamentou o aviso prévio proporcional ao tempo de trabalho.

${ }^{41}$ Constituição Federal, artigo $7^{\circ}$, incisos VI, XIII e XIV.
} 
discriminação no tocante a salário e critérios de admissão do trabalhador portador de deficiência (inciso XXXI). Como há notória dificuldade adicional na prestação do trabalho noturno, a remuneração deste deve ser superior ao do trabalho diurno (inciso IX). O mesmo raciocínio, que aumenta a remuneração quando da constatação de maior esforço do trabalhador, embasa a previsão de adicional salarial quando o trabalho é penoso, insalubre ou perigoso (inciso XXIII), e quando há trabalho em horas extras, sendo que, neste último caso, o acréscimo deve ser no mínimo de 50\% (inciso XVI).

Sendo uma atividade humana e com enorme repercussão individual e social, o exercício do trabalho depende do pleno gozo de saúde por parte de quem o realiza. Nesse sentido, surge a necessidade do repouso e dos períodos de inatividade, as quais visam permitir que o trabalhador recupere suas energias e preserve sua integridade física e, principalmente, nos dias de hoje, mental. Garantindo o direito ao repouso e a inatividade, a Carta determina o repouso semanal remunerado, preferencialmente aos domingos (inciso $\mathrm{XV}$ ), e o gozo de férias anuais remuneradas com pelo menos um terço a mais que o salário normal.

Por vezes, diante de determinados acontecimentos, o repouso do trabalhador se torna vital, em alguns casos pelos aspectos físicos, em outros pelos aspectos sociais envolvidos. É o que ocorre quando há maternidade, e por isso a Constituição prevê a licença-maternidade de 120 dias e a paternidade, de cinco dias, permitindo à mãe a recuperação de sua saúde e a atenção ao recém-nascido e ao pai o auxílio nos primeiros dias de vida de seu filho, além do necessário convívio familiar.

A Carta Fundamental ampliou as hipóteses de proteção ao trabalhador. Em ordem topológica, iniciou asseverando a proteção ao mercado de trabalho da mulher, mediante incentivos específicos, nos termos da lei (inciso XX). Atenta às mudanças dos métodos de produção, buscou proteger o trabalhador contra as inovações tecnológicas supressivas de postos de trabalho, determinando que a lei indique alguma forma de proteção em face da automação. Em relação à proteção à saúde do trabalhador, além da previsão de normas de saúde e segurança acima mencionadas, determinou que o empregador arque com o seguro contra acidentes de trabalho, operacionalizado pelo INSS, sem excluir a responsabilidade dos empregadores pela indenização cabível, no caso de dolo ou culpa. Deve-se proteger, segundo o Texto Maior, não só o trabalhador como também seus dependentes, e para tanto temos o salário-família, já contemplado na Carta de 1967, mas agora cabível somente para os trabalhadores de baixa renda (inciso XII); e também a previsão de assistência gratuita 
aos filhos e dependentes dos empregados e avulsos, desde o nascimento até cinco anos de idade em creches e pré-escolas (inciso XXV).

Há também, nos casos de medidas isonômicas ou não discriminatórias, uma dimensão protetiva, como ocorre por exemplo quando da igualdade de direitos entre os trabalhadores urbanos e rurais (caput do artigo $7^{\circ}$ ), e os empregados e os avulsos (inciso XXXIV). Finalizando as disposições protetivas, há as garantias relativas à ação quanto aos créditos dos trabalhadores urbanos e rurais, que, segundo o inciso XXIX, prescrevem em cinco anos, com limite de até dois anos após o término do contrato de trabalho.

Inovando nos direitos dos trabalhadores, mas coerente com as disposições sobre a ordem econômica e social que valorizam o trabalho, a Constituição, além de prever a participação nos lucros e resultados da empresa, previu ainda a cooperação na própria atividade do empregador, por meio da participação na gestão da empresa, segundo regulamentação por meio de lei (inciso XI).

Os direitos coletivos dos trabalhadores constantes do artigo $8^{\circ}$ se exprimem na autonomia sindical, na medida da proibição da intervenção na organização dos sindicatos, na liberdade de associação e na obrigatoriedade do sindicato em participar das negociações coletivas. Porém, nos cabe registrar, constrangidos, a manutenção da famigerada unicidade sindical e da contribuição sindical, verdadeiro imposto, resquícios do sistema corporativista implantado pelo regime fascista italiano e hoje limitadores da verdadeira atividade sindical no Brasil.

\subsection{Direito Constitucional da Seguridade Social}

O Título VIII da Constituição da República Federativa do Brasil trata da Ordem Social e, logo no artigo 193, estipula que "a ordem social tem como base o primado do trabalho, e como objetivo o bem-estar e a justiça sociais."

Parece-nos relevante a afirmação, mormente no tocante ao conceito que temos de seguridade social. Lord Beveridge, economista inglês criador do plano de seguridade social que inspira modelos de proteção social por todo o mundo, afirmava que o cidadão deveria ter proteção social do nascimento ao túmulo. Partilhamos dessa posição com o acréscimo das considerações que passaremos a tecer.

Consideramos o trabalho um dos fatores mais importantes da dignidade humana. Em sua mais ampla acepção, o trabalho é fonte de realização, de sustento, de orgulho do 
ser humano. É o caminho para a expressão de toda potencialidade do homem e é esta visão que funda a qualificação do trabalho como direito fundamental do homem e da mulher.

Toda relevância do trabalho, vista em uma perspectiva individualista, se avoluma em importância ao se transportar a análise para o plano coletivo, para o plano social, no mínimo ao se recordar a contribuição da atividade laboral para o consumo, induzido pela renda do trabalhador, e para a arrecadação tributária. Decorre dessa magnitude a escolha do Constituinte em apoiar a ordem social no primado do trabalho.

Prestado pelo homem, o trabalho sofre os efeitos da fragilidade da vida humana. Todas as vicissitudes que acometem o homem influenciam sua capacidade de prestar serviços, que, por toda relevância que possui, não pode restar desprotegida. Mister realçar que a própria ordem social, estabilizada pela atividade produtiva dos cidadãos, é solapada nos momentos crônicos que afetam as relações de trabalho, mormente em seus aspectos coletivos.

Visando à proteção do trabalhador quando ele é tolhido de sua capacidade laboral, temporária ou permanentemente, surge a proteção estatal, em seus primórdios como consequência do chamado risco profissional e, nesse sentido, com um caráter eminentemente previdenciário. $^{42}$ Tal proteção é consubstanciada, por vezes, na recomposição da renda perdida em razão da incapacidade laboral ou na prestação de serviços que visem à recuperação do trabalhador.

Neste ponto voltamos à concepção da proteção social de Lord Beveridge, 'do nascimento à velhice'. Ao adotarmos tal nível de tutela, inegável o extrapolamento da visão do risco profissional acima apresentada, o que nos obriga a abandonar uma visão previdenciária em busca de um conceito ampliado de segurança social, que contemple não só os riscos decorrentes do exercício de uma atividade profissional, mas também os eventos futuros e incertos que permeiam a vida do ser humano, do princípio ao fim de sua existência.

A esse sistema de segurança extensivo a todos e com cobertura que transcenda os limites da capacidade de trabalho denominou-se seguridade social. Por todo o exposto, entendemos ser seguridade social a ação estatal que visa proteger o cidadão, e os residentes naquele Estado, contra os riscos definidos pela sociedade, por meio de lei, assegurando prestações, em dinheiro ou em espécie, que permitam ao beneficiado suprir sua necessidade de renda ou complementar seu gasto, objetivando superar dignamente os

${ }^{42}$ Cf. HORVATH Jr., Miguel. Direito previdenciário. $7^{\mathrm{a}}$ ed., São Paulo: Quartier Latin, 2008. p. 21. 
efeitos do risco socialmente protegido e recuperar sua saúde, realçando a participação no custeio do próprio segurado, nos casos legalmente previstos.

Verdadeira expressão do Welfare State, do Estado do Bem-Estar Social, o sistema de seguridade social foi adotado pela Carta Cidadã nos termos que passaremos a apreciar, adotando como método a análise do próprio texto constitucional.

Em que pese nosso esforço de conceituação de seguridade social, acima empreendido, vamos nos ater, por motivos didáticos, à definição constante do artigo 194 da Constituição, que assevera ser a seguridade social "um conjunto integrado de ações de iniciativa dos Poderes Públicos e da sociedade, destinadas a assegurar os direitos relativos à saúde, à previdência e à assistência social." Observamos que a conceituação se inicia explicitando que a segurança social será alcançada por meio de um conjunto de ações do Poder Público e da sociedade, o que denota, em primeiro lugar, a amplitude de atitudes pelas quais se promoverá a tutela dos direitos previstos pela Carta. Em segundo lugar, consta a explicitação da solidariedade do sistema de proteção social, na determinação da atuação conjunta entre os poderes públicos e a sociedade, ou seja, todos - inclusive os próprios beneficiados - devem agir para a consolidação dos direitos protetivos, àqueles relativos à saúde, à previdência e à assistência social.

O sistema delineado está enfeixado pelos princípios $^{43}$ descritos no parágrafo único do mencionado artigo 194, a saber:

\footnotetext{
I - universalidade da cobertura e do atendimento;

II - uniformidade e equivalência dos benefícios e serviços às populações urbanas e rurais;

III - seletividade e distributividade na prestação dos benefícios e serviços;

IV - irredutibilidade do valor dos benefícios;

$\mathrm{V}$ - equidade na forma de participação no custeio;

VI - diversidade da base de financiamento;

VII - caráter democrático e descentralizado da administração, mediante gestão quadripartite, com participação dos trabalhadores, dos empregadores, dos aposentados e do Governo nos órgãos colegiados.
}

A análise da Seguridade Social em nosso país requer uma reflexão sobre os pilares principiológicos relatados, pois esses são norteadores da legislação regulamentadora do tema. De plano, observamos que o sistema de segurança social deve garantir a

\footnotetext{
${ }^{43}$ Adotamos, nesse ponto, a posição de Dworkin no sentido de serem os princípios uma dimensão de peso, pois 'enunciam razões que conduzem a uma direção, sem especificar qual a decisão particular a ser tomada'. Cf. BOllmann, Vilian. PREVIDÊnCIA E JUSTIÇA: O Direito Previdenciário no Brasil sob o Enfoque da Teoria da Justiça de Aristóteles. Curitiba: Juruá, 2009. p. 30.
} 
universalidade da cobertura e do atendimento. Quanto à primeira, é forçoso reconhecer o comando deixado pelo Constituinte ao legislador ordinário, explicitando um desdobramento objetivo que se traduz pela amplitude da cobertura dos riscos, ou seja, todas as contingências sociais ligadas aos objetivos da saúde, da previdência e da assistência social devem ser cobertos. No tocante à segunda, a universalidade do atendimento, encontramos um desdobramento subjetivo, pois aqui deve o legislador garantir que todos os cidadãos tenha acesso ao atendimento pelo sistema de Seguridade. Tal comando, porém, não pode ser entendido em sua acepção mais ampla, uma vez que é ínsito, por expressa disposição do artigo 201 da própria Constituição, o caráter contributivo da Previdência Social, o que, por óbvio, restringe o acesso aos benefícios previdenciários àqueles que contribuem com o sistema.

Superando uma dicotomia de inegável injustiça, o Poder Constituinte Originário esculpiu na Carta Magna a uniformidade e equivalência dos serviços e benefícios da Seguridade às populações urbanas e rurais. As atividades rurais, empreendidas no mais das vezes em regime de economia popular, além de exercidas em sofridas condições de trabalho, têm um potencial gerador de renda menor que as atividades urbanas. Tal constatação, com a consequente redução na capacidade de contribuição, faz do setor rural um segmento deficitário para a Seguridade Social, ou seja, mais onera do que contribui ao Sistema.

Porém, tal condição não impediu que a Carta expressasse, com base nos princípios da solidariedade, da isonomia e da universalidade de cobertura, a uniformidade e equivalência das prestações. Ao reverso, imputou às atividades urbanas parte do custeio do sistema rural de seguridade social, ${ }^{44}$ uma vez que ao trabalhador rural não pode responsabilizar-se pela diferença na capacidade econômica de cada setor.

O terceiro princípio constitucional da Seguridade Social, segundo o artigo 194, é o da seletividade e distributividade na prestação dos benefícios e serviços. Linhas atrás, afirmamos que os direitos sociais são direitos tidos como positivos na medida em que são prestados pelo Estado, e nesse sentido se opõem aos direitos negativos, que - típicos da primeira geração dos direito fundamentais - são deveres de abstenção do Estado, atuação no sentido da não intervenção na esfera de liberdade do indivíduo. Assim, os diretos sociais demandam do Estado um custo para sua efetivação, o que enseja uma limitação

\footnotetext{
${ }^{44}$ Corrobora a afirmação a disposição do artigo $195, \S 8^{\circ}$, que estipula uma contribuição previdenciária mais favorável para o segurado especial, assim considerado o pequeno produtor rural que exerce sua atividade em regime de economia familiar.
} 
óbvia, a limitação orçamentária, que, de tão proclamada, levou à criação do princípio da reserva do possível, isto é, o Poder Público tem uma capacidade restrita de agir, limitada pelos seus recursos.

Do cotejo do exposto sobre o princípio da universalidade de cobertura e de atendimento, encontremos o princípio da seletividade e distributividade. Tal princípio permite ao legislador ordinário respeitar as restrições orçamentárias e cumprir as diretrizes do princípio da universalidade de cobertura simultaneamente, uma vez que por seletividade se entende a escolha do legislador no sentido da prestação do benefício ou serviço de maior relevância, aquele essencial à população. Zambitte, apoiado em Wagner Balera, diz que a "seletividade atua de delimitação do rol de prestações, ou seja, na escolha dos benefícios e serviços a serem mantidos pela seguridade social." 45

Por seu turno, a distributividade é entendida como a capacidade do sistema de redistribuir renda, atuando, portanto na desigualdade social, atendendo as pessoas mais necessitadas e definindo o grau de proteção. Tais disposições validam que algumas prestações não sejam extensíveis a todos os segurados, sendo exemplo perfeito e acabado de seletividade. ${ }^{46}$ Uma característica dos benefícios sociais é que a maioria de seus usuários se localiza nas regiões mais carentes do país, e, ao serem oferecidos a esses segurados, os benefícios consubstanciam o princípio da distributividade, pois minimizam a desigualdade social. ${ }^{47}$

A irredutibilidade do valor do benefício é um princípio constitucional que deve ser analisado sob a ótica da interpretação histórica. Prescindimos de maior explicação jurídica quando recordamos que, à época da elaboração da Constituição Federal, o país ainda vivia sob o fardo da inflação crônica que nos abateu por mais de trinta anos, por vezes de

\footnotetext{
${ }^{45}$ Cf. IBRAHIM, Fábio Zambitte. Curso de Direito Previdenciário. 16 ed., Niterói: Impetus, 2011. p. 67.

${ }^{46}$ Concordamos com Zambitte que o salário-família, que é devido somente ao trabalhador de baixa renda, é exemplo da utilização acertada do princípio da seletividade, uma vez que complementar o rendimento do trabalhador que possua filhos de até 14 anos só faz sentido para as famílias de menor renda. No outro sentido, do erro na aplicação do princípio, temos o auxílio-reclusão, que deveria ser extensivo a todos os segurados, pois, ao ser preso o trabalhador perde a capacidade de sustentar sua família, qualquer que seja o seu nível de renda. (Cf. IBRAHIM, Fábio Zambitte. Curso de Direito Previdenciário. 16ª ed., Niterói: Impetus, 2011. p. 68.)

${ }^{47}$ Quando de nossa atuação como Auditor Fiscal da Receita Previdenciária na Gerência Executiva do INSS em Juazeiro do Norte, CE, pudemos observar a influência que os benefícios sociais, especialmente os previdenciários, têm sobre a economia das cidades do interior das regiões menos desenvolvidas do país. $\mathrm{O}$ volume de recursos transferidos pela Previdência Social aos seus segurados é maior que a participação destes municípios no Fundo de Participação previsto no artigo 159 da CF. (Cf. IBRAHIM, Fábio Zambitte. ob.cit.p. 68)
} 
maneira mais intensa, por vezes de forma mais controlada. ${ }^{48}$ Nesse aspecto, o princípio da irredutibilidade do valor do benefício versa sobre o valor real da prestação pecuniária, ou seja, o segurado deve perceber um valor que não seja reduzido por efeitos econômicos, mantendo seu poder de compra por meio de reajustes periódicos toda vez que se faça necessário, consoante o disposto no artigo 201, §4º , do Texto Fundamental.

No inciso V do acima transcrito artigo 194, encontramos a previsão do princípio da equidade na forma de participação no custeio, que parte da doutrina ${ }^{49}$ entende como sendo a previsão para que cada contribuinte participe do custeio do sistema na medida de sua possibilidade, o que representa o desdobramento do princípio da capacidade contributiva tributária, estatuído no artigo $145, \S 1^{\circ}$, da Constituição. Vemos a questão sob outro aspecto. A contribuição à seguridade social apresenta inegável traço da solidariedade que é ínsita ao sistema de segurança social brasileiro. ${ }^{50}$ Disso exsurge a participação de todos, trabalhadores, empregadores, sociedade e do Estado. É cabível a dispensa de alguns, no caso de comprovada miserabilidade, restando aos demais o custeio do sistema, seja diretamente ou indiretamente.

Explicitada a necessidade da contribuição de todos para a segurança social, o princípio da equidade norteia a forma dessa contribuição, em razão da determinação da participação equânime dos empregadores e dos trabalhadores, por vezes até de forma diversa da usual. É o que ocorre, por exemplo, quando há substituição da base de cálculo das empresas ou quando os benefícios não têm relação direta com o custeio, como na cobertura da impossibilidade de trabalho por doença. Percebe-se, de maneira mais direta, o cumprimento do princípio da equidade quando o legislador procede de maneira diversa da comentada, ou seja, majora uma alíquota em função de maior demanda pelo benefício, como se verifica nos benefícios decorrentes de acidente de trabalho, nos quais há maior alíquota para as atividades mais perigosas, e quando empresas de segmento econômico que pouco se utilizam de mão-de-obra têm alíquotas mais elevadas para compensar a arrecadação entre os setores.

\footnotetext{
${ }^{48}$ A corroborar a afirmação, recordamos que a Carta de 1988 é fruto da convocação da Assembleia Nacional Constituinte, eleita em 1986 sob os efeitos do plano econômico que pretendia estabilizar e economia, por meio de reforma monetária e foi denominado 'Plano Cruzado', previa congelamento de preços e salários e pretendia controlar a inflação que atingiu 225,16 \% no ano anterior a sua criação.

${ }^{49}$ Nesse sentido HORVARTH Jr., Miguel. Direito Previdenciário. 7a ed., São Paulo: Quartier Latin, 2008. p.95. VIANNA, João Ernesto Aragonés. Curso de Direito Previdenciário. $4^{a}$ ed., São Paulo: Atlas, 2011. p. 18.

${ }^{50}$ Cf. BOLlMANN, Vilian. PREVIDÊnCIA E JUSTIÇA: O Direito Previdenciário no Brasil sob o

Enfoque da Teoria da Justiça de Aristóteles. Curitiba: Juruá, 2009. p. 25.
} 
Entendemos que o princípio do inciso VI do parágrafo único do artigo 194, o princípio da diversidade da base de financiamento, apresenta o apreço e a cautela do Constituinte pelo equilíbrio das fontes de custeio da Seguridade Social. O Legislador Originário soube ser prudente, soube agir como o bonus pater familias, resguardando os recursos da Seguridade ao diversificar as suas fontes de custeio, como se pode observar ao analisarmos o artigo 195 da Constituição. ${ }^{51}$ Além de instituir contribuição a cargo do

empregador, do trabalhador, incidente sobre a folha de salários, buscou recursos nos orçamentos dos Estados, Municípios, Distrito Federal e da própria União. Mais além, o legislador elegeu como fato gerador de contribuição à seguridade social o faturamento, posteriormente ampliado para a receita das empresas, além do lucro.

No mesmo artigo, é explicitado que deve incidir contribuição sobre a importação de bens e produtos do exterior, e que parte da arrecadação dos concursos de prognósticos deve ser destinada para compor a base de financiamento da seguridade social. Não obstante o exposto, na eventualidade de falta de recursos, caberá à União complementar o montante necessário, não havendo previsão para o corte nos benefícios ou redução do valor destes. ${ }^{52}$

Por fim, tratemos do princípio do caráter democrático e descentralizado da Administração da Seguridade Social. Decorrendo do "sobre princípio" da solidariedade, que une os trabalhadores, os empregadores e a sociedade ao Estado, a administração do sistema de segurança social é feita de forma quadripartite, pois conta com representantes dos quatro setores mencionados no Conselho Nacional de Previdência Social, constituído por seis representantes do governo federal e nove representantes da sociedade, distribuídos em três vagas para os representantes dos aposentados e pensionistas, três vagas para os representantes dos trabalhadores $\mathrm{e}$ as últimas três para os representantes dos

\footnotetext{
${ }^{51}$ Art. 195. A seguridade social será financiada por toda a sociedade, de forma direta e indireta, nos termos da lei, mediante recursos provenientes dos orçamentos da União, dos Estados, do Distrito Federal e dos Municípios, e das seguintes contribuições sociais:

I - do empregador, da empresa e da entidade a ela equiparada na forma da lei, incidentes sobre: a) a folha de salários e demais rendimentos do trabalho pagos ou creditados, a qualquer título, à pessoa física que lhe preste serviço, mesmo sem vínculo empregatício; b) a receita ou o faturamento; c) o lucro; II - do trabalhador e dos demais segurados da previdência social, não incidindo contribuição sobre aposentadoria e pensão concedidas pelo regime geral de previdência social de que trata o art. 201; III - sobre a receita de concursos de prognósticos.

(...)

IV - do importador de bens ou serviços do exterior, ou de quem a lei a ele equiparar.

${ }^{52}$ Cf. IBRAHIM, Fábio Zambitte. Curso de Direito Previdenciário. $16^{\mathrm{a}}$ ed., Niterói: Impetus, 2011. p. 73.
} 
empregadores. ${ }^{53}$ Todos os membros, titulares e suplentes, do CNPS são nomeados pelo Presidente da República para um mandato de dois anos, podendo ser reconduzidos uma única vez.

Vistos os princípios que norteiam a Seguridade Social no Brasil, passemos agora a analisar seus órgãos, verdadeiros agentes de implementação da proteção social esculpida na Carta da República.

\subsubsection{Da Saúde}

Hoje, ouvimos e vemos como verdadeira máxima da República, inclusive em propagandas oficiais, o ditame do artigo 196 da Constituição, ${ }^{54}$ que explicita ser a saúde um direito de todos e dever do Estado. ${ }^{55}$ O Poder Público, diretamente ou por meio de terceiros, deverá realizar as ações e os serviços de saúde, podendo franquear à iniciativa privada os serviços de saúde, desde que respeitados os princípios constitucionais.

Merece destaque a determinação constitucional do acesso universal e gratuito, independentemente de contribuição, ao sistema público de saúde. Rompeu-se com o sistema anteriormente vigente, que vinculava a saúde à previdência social por meio do o Instituto Nacional de Assistência Médica da Previdência Social (INAMPS), que exigia, para que o segurado tivesse acesso à saúde, a contrapartida, ou seja, a contribuição previdenciária, restando àqueles que não fossem filiados ao regime previdenciário a benemerência das Santas Casas de Misericórdia. Hoje, nem o fato de o cidadão ter condições financeiras de suportar o atendimento privado não o exclui do sistema público. Por acesso universal entende-se o franqueamento do sistema público de saúde ao nacional e aos estrangeiros residentes no país.

Como dito alhures, a saúde compreende não só a ausência de enfermidade, mas também a integridade física, psíquica, mental e social do indivíduo. O sistema de saúde deve atender não só os casos de recuperação do doente, mas também a prevenção e a

\footnotetext{
${ }^{53}$ A composição do CNPS está definida pelo artigo $3^{\circ}$ da Lei ${ }^{\circ}$ 8.213, de 1991.

${ }^{54}$ Constituição, art. 196. "A saúde é direito de todos e dever do Estado, garantido mediante políticas sociais e econômicas que visem à redução do risco de doença e de outros agravos e ao acesso universal e igualitário às ações e serviços para sua promoção, proteção e recuperação."

${ }^{55}$ Verdadeira fonte de contradições, convivemos de um lado, com um sistema de saúde de excelência para os quadros especialmente graves, mormente nas regiões Sul e Sudeste. Por outro, mesmo nessas regiões mais desenvolvidas do país, encontramos uma situação de verdadeiro desrespeito à vida humana para os problemas mais comezinhos da população, com pacientes sendo atendidos em corredores de hospitais totalmente lotados.
} 
proteção. O sistema público de saúde, integrado em sistema único que atua através de uma rede regionalizada e hierarquizada, obedece, além do princípio do acesso universal e gratuito, as seguinte diretrizes: descentralização, com direção única em cada esfera de governo; atendimento integral, com prioridade para as atividades preventivas, sem prejuízo dos serviços assistenciais; e participação da comunidade na gestão, fiscalização e acompanhamento das ações e serviços de saúde.

A Lei n ${ }^{\circ}$ 8080, de 1990, criou o Sistema Único de Saúde (SUS), e dispôs sobre as condições para a promoção, proteção e recuperação da saúde, além da organização e funcionamento dos serviços correspondentes. Lei estruturante atribuiu ao SUS, por meio de seu artigo $6^{\circ}$, as ações e serviços que devem ser prestados por órgãos e instituições federais, estaduais e municipais, com vistas ao atendimento dos seguintes objetivos: a identificação e divulgação dos fatores condicionantes e determinantes da saúde; a formulação de política de saúde destinada a promover, nos campos econômico e social, a redução de riscos de doenças e de outros agravos e no estabelecimento de condições que assegurem acesso universal e igualitário às ações e serviços ofertados; e a assistência às pessoas por intermédio de ações de promoção, proteção e recuperação da saúde, com a realização integrada das ações assistenciais e das atividades preventivas. As atribuições comuns a cada esfera de governo estão elencadas no artigo 15 da Lei n ${ }^{\circ} 8.080$, de 1990, e as específicas constam dos artigos 16 ao18 do mesmo diploma. Importante a previsão do artigo 10, que contempla a possibilidade de os municípios formarem consórcios para desenvolver em conjunto as ações e os serviços de saúde que lhes correspondam. No mesmo diapasão, o artigo 12 avaliza a criação de comissões intersetoriais de âmbito nacional, subordinadas ao Conselho Nacional de Saúde, integradas pelos Ministérios e órgãos competentes e por entidades representativas da sociedade civil, para articular políticas e programas de interesse para a saúde, cuja execução envolva áreas não compreendidas no âmbito do Sistema Único de Saúde (SUS), como por exemplo, alimentação e nutrição, saneamento e meio ambiente, vigilância sanitária e farmacoepidemiologia, ciência e tecnologia e saúde do trabalhador.

A participação da comunidade na gestão do Sistema é prevista pela Lei $n^{\circ} 8.142$, de 1990, cumprindo um preceito constitucional, por meio da criação em cada esfera de governo da Conferência de Saúde e do Conselho de Saúde. Esse órgão é um colegiado composto por representantes do governo, prestadores de serviço, profissionais de saúde e usuários e possui caráter permanente e deliberativo, além de atuar na formulação de 
estratégias e controlar a execução da política de saúde, inclusive nos aspectos econômicos e financeiros. Seria o equivalente ao Conselho Nacional de Previdência Social. Além do Conselho, a cada quatro anos, segundo a Lei $\mathrm{n}^{\mathrm{o}}$ 8.142, deve ser instaurada uma Conferência de Saúde, com participação de representantes de vários segmentos sociais para avaliar a situação e propor as diretrizes para a formulação de políticas de saúde no nível de atuação da Conferência.

A mesma Lei $n^{\circ} 8.142$ condiciona o recebimento dos valores do Fundo Nacional da Saúde à criação de seu próprio Fundo e também à efetiva criação do Conselho de Saúde pelo Ente Federativo. Devemos ressaltar a previsão constante do artigo 198, §2 ${ }^{\circ}$, da Constituição, que determina que a União, os Estados, o Distrito Federal e os Municípios deverão aplicar, anualmente, em ações e serviços públicos de saúde, recursos mínimos de suas receitas, resultantes de um percentual, definido em Lei Complementar, ${ }^{56}$ além das parcelas repassadas pelo Fundo Nacional de Saúde (FNS), pela União e pelos Fundos de Participação dos Estados e Municípios.

\subsubsection{Da Assistência Social}

Voltada a assegurar o mínimo existencial àqueles incapazes, por si e por seus familiares, de prover seu próprio sustento, a Assistência Social será prestada a quem dela necessitar, independentemente de contribuição. O beneficiário da Assistência Social se encontra, momentânea ou permanentemente, incapacitado para garantir seu próprio sustento, as condições mínimas para sua sobrevivência. Mais que isto, ele ou não possui família, ou esta também não tem condições de promover condições dignas de vida ao indivíduo. Essas condições ensejam a tutela estatal.

Os objetivos previstos pelo Texto Maior para a Assistência Social constam do artigo 203 e são: a proteção à família, à maternidade, à infância, à adolescência e à velhice; o amparo às crianças e adolescentes carentes; a promoção da integração ao mercado de trabalho; a habilitação e reabilitação das pessoas portadoras de deficiência e a promoção de

\footnotetext{
${ }^{56}$ Em 13 de janeiro de 2012, foi publicada a Lei Complementar $n^{\text {o }} 141$ que regulamentou o artigo 198 , $\S 3^{\circ}$, da Carta da República. Segundo o artigo $5^{\circ}$ desta lei, a União deverá aplicar em saúde o montante aplicado em exercício anterior acrescido por percentual equivalente à variação nominal do Produto Interno Bruto (PIB), ocorrido no ano anterior, sendo vedada a redução do valor anteriormente aplicado mesmo no caso de variação negativa do PIB. Os Estados e Distrito Federal, segundo o artigo $6^{\circ}$, aplicarão no mínimo $12 \%$ de suas receitas ali discriminadas, descontadas as parcelas transferidas aos Municípios. Estes, por sua vez, juntamente com o Distrito Federal, deverão aplicar em saúde $15 \%$ de suas receitas mencionadas no artigo $7^{\circ}$ da $\operatorname{LC~}^{\circ} 141$, de 2012.
} 
sua integração à vida comunitária; e, por fim, a garantia de um salário-mínimo de benefício mensal à pessoa portadora de deficiência e ao idoso que comprovem não possuir meios de prover a própria manutenção ou de tê-la provida por sua família, conforme dispuser a lei.

Os recursos necessários para o alcance do desiderato buscado devem ser obtidos no orçamento da Seguridade Social, que, como visto, foi eleito, pela Carta, como fonte de meios do sistema previdenciário, de saúde e de assistência. Além da possibilidade de alocação de outros recursos, segundo o artigo 204, com a redação da Emenda Constitucional 42, de 2003, os Estados e o Distrito Federal podem ainda vincular até cinco décimos por cento de sua receita tributária líquida ao programa de apoio à inclusão e promoção social, vedada a aplicação desses recursos no pagamento de despesas com pessoal e encargos sociais; com serviço da dívida e ainda com qualquer outra despesa corrente não vinculada diretamente aos investimentos ou ações apoiados.

A Lei nº 8.742, de 1993, denominada Lei Orgânica da Assistência Social (LOAS), regulamenta e organiza a Assistência Social, que é hodiernamente a grande fonte de redistribuição de renda e reinclusão social promovida pelo Poder Público. ${ }^{57} \mathrm{Em}$ complemento a nossa definição, transcrevemos a conceituação da lei para a Assistência Social:

Art. $1^{\circ}$ A assistência social, direito do cidadão e dever do Estado, é Política de Seguridade Social não contributiva, que provê os mínimos sociais, realizada através de um conjunto integrado de ações de iniciativa pública e da sociedade, para garantir o atendimento às necessidades básicas.

A Lei $\mathrm{n}^{\mathrm{o}}$ 12.435, de 2011, altera a LOAS e amplia os objetivos da Assistência Social, ao alterar a redação do artigo $2^{\circ}$ como abaixo transcrito:

Art. $2^{\circ} \mathrm{A}$ assistência social tem por objetivos: (Redação dada pela Lei $\mathrm{n}^{\circ}$ 12.435, de 2011)

...

\footnotetext{
${ }^{57}$ O programa Bolsa família, criado pela Lei ${ }^{\circ}$ 10.836, de 2004, é hoje distribuído a mais de 16 milhões de brasileiros com renda per capita inferior a $\mathrm{R} \$ 70,00$, segundo dados do Ministério do Desenvolvimento Social e Combate à Fome. Aliado ao Bolsa Família, hoje existem os seguintes programas assistenciais que apresentam características de distribuição de renda e reinclusão social: Programa de Atenção Integral à Família (PAIF); Centro de Referência e Assistência Social (CRAS); Centro de Referência Especializado de Assistência Social (CREAS); Projeto Agente Jovem do Desenvolvimento Social e Humano; Projeto de Erradicação do Trabalho Infantil (PETI); Banco de Alimentos; Cozinhas Comunitárias; Distribuição de Alimentos etc. Cf VIANNA, João Ernesto Aragonés. Curso de Direito Previdenciário. $4^{\text {a }}$ ed., São Paulo: Atlas, 2011. p. 42.
} 
II - a vigilância socioassistencial, que visa a analisar territorialmente a capacidade protetiva das famílias e nela a ocorrência de vulnerabilidades, de ameaças, de vitimizações e danos;

III - a defesa de direitos, que visa a garantir o pleno acesso aos direitos no conjunto das provisões socioassistenciais.

Parágrafo único. Para o enfrentamento da pobreza, a assistência social realiza-se de forma integrada às políticas setoriais, garantindo mínimos sociais e provimento de condições para atender contingências sociais e promovendo a universalização dos direitos sociais.

A inclusão de ações de vigilância socioassistencial com foco em análise territorial denota uma atuação mais proativa da assistência estatal, ações que, acrescidas de medidas que visem garantir o pleno acesso ao conjunto de medidas protetivas, tendem a aumentar significativamente a inclusão social dos menos favorecidos.

Relevante a reorganização sistêmica projetada pela mencionada Lei ${ }^{\circ} 12.435$, de 2011, com a criação do Sistema Único de Assistência Social (SUAS), cujos objetivos estão elencados nos diversos incisos do artigo $6^{\circ}$ da Lei $n^{\circ} 8.742,1993,{ }^{58}$ com a redação da citada Lei $\mathrm{n}^{\circ}$ 12.435. O SUAS é integrado pelos entes federativos, pelos respectivos conselhos de assistência social e pelas entidades e organizações de assistência social abrangidas pela Lei $\mathrm{n}^{\circ} 8.742$.

Dentre as competências da União no SUAS, está a de cofinanciar, por meio de transferência automática, o aprimoramento da gestão, os serviços, os programas e os projetos de assistência social em âmbito nacional, além de atender às ações assistenciais de caráter de emergência em conjunto com os Estados, o Distrito Federal e os Municípios. ${ }^{59}$ A lei reservou aos Estados ${ }^{60}$ competência similar à da União, uma vez que aqueles devem apoiar os Municípios nas ações assistenciais, financeiramente e por meio da prestação de serviços.

\footnotetext{
${ }^{58}$ Lei $\mathrm{n}^{\mathrm{o}} 8.742$, art. $6^{\mathrm{o}}$ : A gestão das ações na área de assistência social fica organizada sob a forma de sistema descentralizado e participativo, denominado Sistema Único de Assistência Social (Suas), com os seguintes objetivos: I - consolidar a gestão compartilhada, o cofinanciamento e a cooperação técnica entre os entes federativos que, de modo articulado, operam a proteção social não contributiva; II - integrar a rede pública e privada de serviços, programas, projetos e benefícios de assistência social, na forma do art. $6^{\circ}$-C; III - estabelecer as responsabilidades dos entes federativos na organização, regulação, manutenção e expansão das ações de assistência social; IV - definir os níveis de gestão, respeitadas as diversidades regionais e municipais; V - implementar a gestão do trabalho e a educação permanente na assistência social; VI estabelecer a gestão integrada de serviços e benefícios; e VII - afiançar a vigilância socioassistencial e a garantia de direitos.

$\S 11^{\circ}$ As ações ofertadas no âmbito do Suas têm por objetivo a proteção à família, à maternidade, à infância, à adolescência e à velhice e, como base de organização, o território.

${ }^{59}$ Lei no 8.742 , de 1993, lista nos artigos 12 e 12-A as competências da União.

${ }^{60}$ Artigo 13 da Lei no 8.742 , de 1993, estabelece as competências dos Estados, e o artigo 14 as do Distrito Federal.
} 
Aos Municípios, os verdadeiros agentes da assistência social, ${ }^{61}$ além do pagamento dos auxílios natalidade e funeral, compete, em parceria com a sociedade civil, a execução dos projetos de enfrentamento da pobreza, o atendimento das ações assistenciais de caráter emergencial, bem como a prestação dos serviços assistenciais previstos no artigo 23 da LOAS. $^{62}$

Não obstante a amplitude da atuação da Assistência Social, mormente com a criação do SUAS, é inegável a importância do benefício assistencial da prestação continuada, que, por ser concedido e administrado pelo INSS, é confundido com a aposentadoria por idade por grande parte da população, pois corresponde à garantia de um salário-mínimo à pessoa portadora de deficiência ou ao idoso com mais de 65, que comprovem não possuir meios de prover a própria subsistência, e nem possua familiares aptos a provê-la. É devido ao brasileiro ou estrangeiro domiciliado no Brasil que não tenha vínculo com sistema de previdência no país de origem.

A LOAS estipulou um critério objetivo para a verificação da impossibilidade de a entidade familiar prover o sustento do idoso ou do deficiente. A adoção de um limite é compatível com o ditame constitucional da disponibilização dos serviços e prestações da Assistência Social aos desvalidos. Segundo o artigo 20, $\S 3^{\circ}$, da lei, considera-se incapaz de prover a manutenção da pessoa com deficiência ou idosa a família cuja renda mensal per capita seja inferior a 1/4 (um quarto) do salário-mínimo. Segundo a dicção legal, a entidade familiar é composta pelo requerente, o cônjuge ou companheiro, os pais e, na ausência de um deles, a madrasta ou o padrasto, os irmãos solteiros, os filhos e enteados solteiros e os menores tutelados, desde que vivam sob o mesmo teto. $O$ benefício pode ser pago a mais de um membro da família, desde que comprovados os requisitos legais, porém ao inválido o benefício será computado na renda familiar, dificultando a concessão aos outros membros, em face do necessário rateio. ${ }^{63}$

\footnotetext{
${ }^{61}$ As competências dos Municípios estão elencadas no artigo 15 da LOAS.

62 Art. 23. Entendem-se por serviços socioassistenciais as atividades continuadas que visem à melhoria de vida da população e cujas ações, voltadas para as necessidades básicas, observem os objetivos, princípios e diretrizes estabelecidos nesta Lei.

$\S 1^{\circ} \mathrm{O}$ regulamento instituirá os serviços socioassistenciais.

$\S 2^{\underline{o}} \mathrm{Na}$ organização dos serviços da assistência social serão criados programas de amparo, entre outros:

I - às crianças e adolescentes em situação de risco pessoal e social, em cumprimento ao disposto no art. 227 da Constituição Federal e na Lei nº 8.069, de 13 de julho de 1990 (Estatuto da Criança e do Adolescente); II às pessoas que vivem em situação de rua.

${ }^{63}$ Por força da disposição constante do Estatuto de Idoso, art. 34, § único, da Lei $n^{\circ}$ 10.741, de 2003, a percepção do benefício de prestação continuada pelo idoso não deve ser computado na renda familiar para efeitos do cálculo da LOAS. Não há tal determinação para o deficiente.
} 
O limite objetivo esculpido na lei é entendido pela jurisprudência como uma presunção relativa de miserabilidade, podendo ser afastada por meio das provas admitidas em direito. No julgamento do REsp 1.112.557-MG, ${ }^{64}$ representativo de controvérsia, o Superior Tribunal de Justiça firmou o entendimento de que a limitação do valor da renda per capita familiar não deve ser considerada a única forma de comprovar que a pessoa não possui outros meios para prover a própria manutenção ou de tê-la provida por sua família, visto que esse critério é apenas um elemento objetivo para aferir a necessidade. Ademais, no âmbito judicial vige o princípio do livre convencimento motivado do juiz, não o sistema de tarifação legal de provas. Assim, essa delimitação do valor da renda familiar per capita não deve ser tida como único meio de prova da condição de miserabilidade do beneficiado, não podendo vincular o magistrado a um elemento probatório sob pena de cercear o seu direito de julgar. Inegável que o entendimento do Tribunal Superior se coaduna com as disposições constitucionais e com os objetivos da Assistência Social de ampliar o acesso aos necessitados.

\subsubsection{Da Previdência Social}

Observamos, linhas atrás, que a seguridade social atua apoiada em um sistema tripartido composto pela Saúde, Assistência Social e Previdência, este último intimamente ligado à proteção da capacidade de geração de renda pelo trabalho, o que decorre dos primórdios dos sistemas assecuratórios originados com a proteção ao risco profissional.

A Constituição Federal preceitua, no artigo 201, que a Previdência Social será organizada na forma de regime geral, de filiação obrigatória e caráter contributivo, observados os critérios que preservem o equilíbrio financeiro e atuarial, e protegerá contra os eventos causados por doença, velhice, invalidez e morte; proporcionará proteção à maternidade, especialmente à gestante; auxiliará o trabalhador quando do desemprego involuntário; concederá aos dependentes do trabalhador de baixa renda salário-família e auxílio-reclusão; e fornecerá pensão por morte do segurado, homem ou mulher, ao cônjuge ou companheiro e dependente. Importante mencionar que nenhum benefício substitutivo de renda do trabalhador, assim entendido aquele que se coloca no lugar do salário-decontribuição, poderá ter valor inferior ao do salário-mínimo. ${ }^{65}$ Tal determinação

\footnotetext{
${ }^{64}$ STJ. REsp 1.112.557-MG. Rel. Min. Napoleão Nunes Maia, julgado em 28/10/2009.

${ }^{65} \mathrm{CF}$, artigo $201, \S 2^{\circ}$.
} 
constitucional não se aplica aos benefícios que não substituem a renda decorrente do trabalho, por exemplo, o salário-família e o auxílio-acidente. ${ }^{66}$

Algumas disposições constitucionais merecem nossa atenção, pois definem o sistema previdenciário pátrio. Em primeiro lugar, a organização é feita por meio de um regime geral, único para todos os trabalhadores da iniciativa privada, uma vez que os servidores públicos estatutários podem se afiliar ao regime próprio, se houver. ${ }^{67}$ Havendo um regime geral, único no âmbito da previdência oficial, entendeu por bem o Constituinte torná-lo compulsório, assim entendido o caráter obrigatório da filiação do trabalhador. Desponta ainda do caput do artigo 201 o caráter contributivo do sistema, ou seja, há a participação do segurado no custeio da Previdência Social. Dito de outro modo, só é segurado da Previdência Social aquele que para ela contribui. Por todo o exposto, podemos inferir que toda pessoa física que trabalha mediante remuneração é segurado obrigatório da Previdência Social e, portanto, dela contribuinte.

Entendemos necessária e eficaz a compulsoriedade de filiação. Dois motivos fundamentam nossa posição. Primeiramente, devemos realçar que a visão preventiva não faz parte da cultura do trabalhador brasileiro médio, ainda mais dos mais jovens. Tal preocupação é mais percebível nas culturas de países com maiores dificuldades climáticas ou mais sujeitos às vicissitudes da natureza. Ao nos recordarmos que a previdência social protege o indivíduo nos casos de incapacidade laboral, observamos que transcende ao aspecto individual a necessidade da proteção, e nesse sentido, a necessidade da filiação, uma vez que toda sociedade é atingida pelos efeitos da perda de capacidade de trabalho do cidadão.

Em segundo lugar, devemos apontar que os sistemas previdenciários podem ser contributivos ou não. Os países que adotam este último sistema, o não contributivo, têm que financiar o sistema de seguridade com recursos do orçamento do Estado, com recursos dos impostos arrecadados, o que onera a sociedade como um todo, além de depender de uma economia forte, o que não é o caso dos países em desenvolvimento. Em arremate, devemos recordar que se houvesse uma faculdade na adesão, as parcelas mais abastadas da população poderiam migrar para a previdência privada, deixando o sistema ainda mais carente de recursos e solapando o caráter solidário que é ínsito ao modelo previdenciário.

\footnotetext{
${ }^{66}$ Cf. VIANNA, João Ernesto Aragonés. Curso de Direito Previdenciário. $4^{a}$ ed., São Paulo: Atlas, 2011. p. 24.

${ }^{67}$ Conforme disposição do artigo 40 da Carta de 1988.
} 
Decorre do caráter contributivo a mitigação do princípio da universalidade de cobertura e do atendimento apontado como enfaixador da seguridade social, no caso da Previdência Social, que se explica pelo modelo adotado. Porém, ao recordarmos que as contribuições previdenciárias fazem parte do orçamento da Seguridade Social e que os sistemas de saúde e assistência social prescindem de contribuição, voltamos a observar uma lógica sistêmica.

Maximizando a solidariedade do sistema previdenciário, encontramos as disposições do artigo 201, $\S \S 12$ e 13, ${ }^{68}$, na redação dada pela Emenda Constitucional $n^{\circ}$ 47, de 2005, que revelam nítida intenção de inclusão previdenciária daqueles trabalhadores que exercem atividades menos valorizadas. Essa política de inclusão, denominada microsseguro, já foi adotada, com sucesso, em outros países e recomendada pela OIT como alternativa à cobertura formal do seguro social em países em desenvolvimento de baixa renda. $^{69}$

Por fim, antes de adentrarmos no exame dos benefícios previdenciários relativos aos riscos previstos na Constituição, devemos assentar que a Previdência Social, mais que uma realidade jurídica, é uma realidade social. Ao fim do primeiro semestre de 2012, as

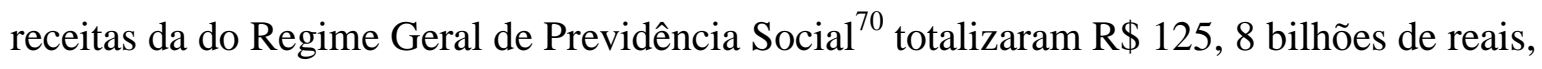
superando em $\mathrm{R} \$ 15,7$ bilhões o resultado de igual período de 2011, sendo que as contribuições previdenciárias, principal fonte de recursos do regime geral, foram o único tributo com crescimento de arrecadação expressivo no período. Foi pago, no mesmo primeiro semestre de 2012, um total de $\mathrm{R} \$ 146,4$ bilhões em benefícios previdenciários, em um total muito superior aos $\mathrm{R} \$ 94,2$ bilhões de transferência da União para os Estado e Municípios por meio dos Fundos de Participação. Tais informações, publicadas pelo Sistema Integrado de Administração Financeira do Governo Federal (SIAFI), demonstram a importância da Previdência Social como agente de redistribuição de renda e diminuição

\footnotetext{
${ }^{68} \mathrm{CF}$, Artigo 201: ..

$\S 12$. Lei disporá sobre sistema especial de inclusão previdenciária para atender a trabalhadores de baixa renda e àqueles sem renda própria que se dediquem exclusivamente ao trabalho doméstico no âmbito de sua residência, desde que pertencentes a famílias de baixa renda, garantindo-lhes acesso a benefícios de valor igual a um salário-mínimo.

$\S 13$. O sistema especial de inclusão previdenciária de que trata o $§ 12$ deste artigo terá alíquotas e carências inferiores às vigentes para os demais segurados do regime geral de previdência social.

...

${ }^{69}$ Cf. VIANNA, João Ernesto Aragonés. Curso de Direito Previdenciário. $4^{\mathrm{a}}$ ed., São Paulo: Atlas, 2011. p. 25.

${ }^{70}$ Os dados a seguir foram extraídos da revista Seguridade Social e Tributação. Ano XXII, $\mathrm{n}^{\circ} 112$, julho/setembro de 2012. Publicação da Associação Nacional dos Auditores Fiscais da Receita Federal do Brasil. p. 26-44.
} 
das desigualdades sociais, principalmente quando recordamos a importância da renda oriunda dos benefícios previdenciários para as famílias e para a economia dos municípios das regiões mais carentes do país.

\subsubsection{Os benefícios previdenciários}

Os cinco incisos do artigo 201 da Carta da República listam os eventos protegidos pela Previdência Social, a saber: cobertura dos eventos de doença, invalidez, morte e idade avançada; proteção à maternidade, especialmente à gestante; proteção ao trabalhador em situação de desemprego involuntário; salário-família e auxílio-reclusão para os dependentes dos segurados de baixa renda; e pensão por morte do segurado, homem ou mulher, ao cônjuge ou companheiro e dependentes.

A Lei de Benefícios, Lei nº 8.213, de 1991, cumpriu a determinação constitucional ao dispor sobre as prestações da Previdência Social que atenderão as contingências constantes da Carta Magna. Observemos, em linhas gerais, suas disposições.

$\mathrm{O}$ atendimento às situações provocadas por doenças, resultantes de acidentes de trabalho ou patologias comuns, serão suportadas pelo auxílio-doença. ${ }^{71}$ Este será devido ao segurado que, havendo cumprido, quando for o caso, o período de carência, ficar impossibilitado para o trabalho ou para sua atividade habitual por mais de 15 dias consecutivos. De plano, podemos concluir que não haverá cobertura previdenciária para as doenças que impedirem os trabalhadores do exercício de sua atividade por menos de 15 dias consecutivos, ou seja, se algum segurado for acometido de uma doença que o impeça da trabalhar por doze dias, ele deverá contar com seus próprios recursos, ou com os de seu empregador, para suprir sua renda durante esse período.

Tal determinação da lei não encontra supedâneo constitucional e é entendida como plausível pela doutrina e jurisprudência por motivos afetos à operacionalização do benefício e capacidade de atendimento pela autarquia previdenciária. Cabe realçar que, havendo recidiva na doença, ou seja, se dentro de um período de 60 dias o segurado voltar a se afastar pelo mesmo motivo, o benefício será devido desde o primeiro dia do afastamento. Se o primeiro afastamento tiver sido de doze dias e houver a recidiva, o benefício será devido após o período faltante para completar os quinze dias, isto é, o benefício será devido após três dias do retorno da doença.

\footnotetext{
${ }^{71}$ Artigos 59 ao 63 da Lei no 8.213, de 1991.
} 
O período de carência previsto na lei é de 12 contribuições, porém, para as doenças ocupacionais e para os afastamentos decorrentes de acidente do trabalho, não há carência a ser cumprida. O valor do benefício consistirá numa renda mensal equivalente a $91 \%$ do salário-de-benefício, que é calculado com base na média corrigida dos $80 \%$ maiores salários-de-contribuição do segurado. Os primeiros quinze dias de afastamento do empregado deverão ser suportados pelo empregador, sendo devidos pelo INSS a partir do $16^{\circ}$ dia de afastamento, depois da necessária perícia médica. No caso dos demais segurados, ele será devido desde o primeiro dia de afastamento, mas, realçamos, somente para as incapacidades que perdurarem por mais de 15 dias.

O segurado em gozo de auxílio-doença, insusceptível de recuperação para sua atividade habitual, deverá submeter-se a processo de reabilitação profissional para o exercício de outra atividade. Não cessará o benefício até que seja dado como habilitado para o desempenho de nova atividade que lhe garanta a subsistência ou, quando considerado não recuperável, for aposentado por invalidez.

A aposentadoria por invalidez, ${ }^{72}$ portanto, é concedida, quando cumprida a carência, se for o caso, ao segurado que seja considerado incapaz para o exercício de atividade que lhe garanta a subsistência, e mais, que não seja passível de reabilitação para outra atividade, e será paga enquanto perdurar essa condição, o que denota o caráter precário dessa modalidade de aposentadoria. Ademais, a aposentadoria por invalidez independe de estar o segurado em gozo do auxílio-doença. Oferta renda mensal de benefício no valor de $100 \%$ do salário-de-benefício, sendo que este valor será majorado em $25 \%$ se o aposentado por invalidez necessitar da assistência permanente de outra pessoa.

Os eventos protegidos pela Previdência decorrentes de idade avançada ensejam o gozo de aposentadoria por idade ${ }^{73}$ e por tempo de contribuição, ${ }^{74}$ segundo as disposições do artigo 201, $\$ 7^{\circ}$ e $\S 8^{\circ}$, da Constituição de 1988. Miguel Horvath Jr. diz que o risco protegido, a velhice, decorre de uma presunção do texto constitucional pelo qual os homens, após 35 anos de contribuição, e as mulheres, após 30 anos de contribuição, estejam desgastados para continuar exercendo suas atividades. ${ }^{75}$ Porém, não só o tempo de

\footnotetext{
${ }^{72}$ Os artigos 42 ao 47 da Lei de Benefícios tratam da aposentadoria por invalidez.

${ }^{73} \mathrm{LB}$, artigos 48 ao 51 .

${ }^{74}$ Para a aposentadoria por tempo de contribuição, ver Regulamento da Previdência Social, RPS, aprovado pelo Decreto no 3.048, de 1999, artigos 56 ao 63 e 188 e 188-A.

${ }^{75}$ Cf. HORVATH Jr., Direito Previdenciário. $7^{\mathrm{a}}$ ed., São Paulo: Quartier Latin. 2008. p. 215.
} 
trabalho enseja a proteção em decorrência da velhice, condição que, em regra, ${ }^{76}$ determina o tempo de contribuição. O próprio advento da idade prevista no Texto Maior, 65 anos para os homens e 60 para as mulheres, determina a cobertura previdenciária. Não se pode olvidar que a aposentadoria por idade exige o cumprimento de carência de 180 contribuições.

A renda mensal da aposentadoria difere quanto ao tipo de benefício obtido. $\mathrm{Na}$ aposentadoria por idade, a renda mensal é calculada aplicando-se um percentual de $70 \%$ do valor do salário-de-benefício acrescido de $1 \%$ para cada grupo de 12 contribuições, segundo as disposições do artigo 50 da Lei de Benefícios. Já no caso da aposentadoria por tempo de contribuição, aos 35 anos de contribuição se homem ou 30 se mulher, a renda mensal consistirá em $100 \%$ do salário-de-benefício multiplicado pelo fator previdenciário. Esse deverá ser calculado com base na idade do segurado quando requerer o benefício, com base na expectativa média de vida do brasileiro segundo o IBGE e com base no tempo de contribuição do segurado ao se aposentar. Em apertada síntese, podemos explicar a complexa fórmula matemática como sendo uma divisão entre a idade do requerente e a expectativa de vida média do brasileiro, o que resulta em um multiplicador menor que um, reduzindo o valor do benefício quanto mais novo for o segurado.

O fator previdenciário foi criado com o objetivo de desestimular a aposentadoria precoce, e, sendo essa inevitável, reduzir seu valor, visando manter o equilíbrio financeiro e atuarial do sistema. ${ }^{77}$ Hoje, e mais ainda no futuro, há um envelhecimento da população, muito em função da melhoria das condições de vida do brasileiro, por consequência dos maiores investimentos em saúde, saneamento, e distribuição de renda. Diante de tal cenário, os efeitos do fator previdenciário são perniciosos aos segurados que se iniciam cedo no mercado de trabalho e cumprem os trinta e cinco anos de contribuição com idade próxima dos cinquenta anos de idade. Tramitam no Congresso Nacional diversos projetos que visam extinguir o fator previdenciário ou mudar radicalmente seu cálculo.

O exercício de determinadas atividades sob condições especiais de trabalho, com maior exposição do trabalhador a agentes nocivos a sua saúde, enseja um tipo de aposentadoria por tempo de contribuição, que se pode dizer acelerado. Em outros termos, com um menor tempo de contribuição surge o direito à inatividade remunerada,

\footnotetext{
${ }^{76}$ Havendo trabalho remunerado, em face da compulsoriedade da filiação, haverá contribuição. Porém, esta também poderá ocorrer de modo volitivo, como no caso do segurado facultativo.

77 Para maior aprofundamento, sugere-se: VIANNA, João Ernesto Aragonés. Curso de Direito Previdenciário. $4^{\mathrm{a}}$ ed., São Paulo: Atlas, 2011. p. 466. IBRAHIM, Fábio Zambitte. Curso de Direito Previdenciário. 16 ed., Niterói: Impetus, 2011. p. 553.
} 
denominada pela Lei $\mathrm{n}^{\circ} 8.213$, de 1991, como aposentadoria especial. ${ }^{78,79}$ Merece destaque que, além do rol de atividades que ensejam as condições particulares ser taxativo, a exposição aos agentes nocivos deve ser permanente e em nível superior à tolerância prevista nas normas regulamentadores expedidas pelo Ministério do Trabalho e Emprego. Cabe ao empregador a comprovação das medidas protetivas que visem reduzir a exposição aos agentes nocivos, além do mapeamento e controle do meio ambiente do trabalho, por intermédio da elaboração de laudos técnicos assinados por médico ou engenheiro do trabalho. Cabe, ainda, a realização dos exames médicos comprovadores da saúde dos trabalhadores, os quais devem ser realizados na admissão, na demissão e periodicamente durante a vigência do contrato de trabalho. Com base nesses dados, serão elaborados e atualizados periodicamente os Perfis Profissiográficos Previdenciários (PPP) de todos os trabalhadores, não olvidando que é por meio do PPP que o trabalhador comprova, junto ao INSS, o trabalho com exposição permanente ao agente nocivo.

Os trabalhadores comprovadamente expostos aos agentes nocivos terão direito à aposentadoria especial aos 25, 20 ou 15 anos de trabalho, dependendo da exposição permanente aos agentes físicos, químicos ou biológicos nos níveis determinados no Regulamento da Previdência Social, aprovado pelo Decreto $n^{\circ} 3.048$. A renda mensal do benefício consistirá numa renda de $100 \%$ do valor do salário-de-benefício. É cabível a contagem proporcional do tempo de trabalho em condições especiais para o gozo de aposentadoria por tempo de serviço.

O auxílio-acidente ${ }^{80}$ é devido nos casos de redução parcial da capacidade de exercício da atividade habitual em decorrência de qualquer acidente. Trata-se de um benefício de caráter indenizatório, que busca reparar o dano causado ao segurado que apresenta lesões consolidadas, as quais resultam em redução da capacidade e, portanto, de geração de renda pelo trabalho habitual do segurado.

Tem direito ao auxílio-acidente o empregado, exceto o doméstico, o trabalhador avulso e o segurado especial. A renda mensal decorrente deste benefício é de $50 \%$ do salário-de-benefício do segurado e é devido desde a constatação da incapacidade até a morte do segurado, ou aposentadoria por qualquer modalidade, e mais, é devido mesmo quando o trabalhador recebe qualquer renda ou benefício previdenciário, exceto novo

\footnotetext{
${ }^{78}$ Para maior aprofundamento, sugere-se: VIANNA, João Ernesto Aragonés. ob. cit.. p. 513. IBRAHIM, Fábio Zambitte. ob. cit. p. 608.

${ }^{79}$ Os artigos 57 e 58 da Lei de Benefícios dispõem sobre a aposentadoria especial.

${ }^{80}$ Lei n $^{\circ} 8.213 / 91$, artigos 18, $\$ 1^{\circ}$, e 86; Regulamento da Previdência Social, artigo 104.
} 
afastamento pela mesma doença ou lesão que tenha gerado o auxílio-acidente, quando o segurado passaria a receber somente o auxílio-doença. A renda mensal do auxílio-acidente pode ser inferior ao salário-mínimo em face de sua natureza indenizatória.

Outro evento de relevância social e por isso protegido pela Previdência Social é a maternidade. ${ }^{81}$ Essa é tutelada tanto no apoio à gestante quanto à criança, para esta por meio indireto, ao garantir o convívio com a mãe nos primeiros quatro meses de vida ${ }^{82}$. A licença-maternidade, na verdade conhecida pelos seus efeitos financeiros, é o único benefício previdenciário que não se submete ao limite máximo do salário-de-contribuição ${ }^{83}$ garantindo à segurada o recebimento de seu salário integral, ${ }^{84}$ ressalvando que este é considerado salário-de-contribuição, e, portanto, sobre ele incidem as contribuições patronais e da própria segurada.

A percepção do salário-maternidade é condicionada à carência de 10 contribuições, somente para as seguradas contribuintes individuais, especiais e facultativas, o que nos permite afirmar que as seguradas empregadas, domésticas e avulsas não têm carência para a obtenção do benefício. Por fim, apontamos que a Lei $n^{\circ} 10.421$, de 2002, estendeu a licença-maternidade às mães adotivas e às guardiãs, porém de maneira proporcional, dependendo da idade da criança adotada. ${ }^{85}$

O benefício denominado salário-família tem, em nossa opinião, a mesma natureza do salário-maternidade, ${ }^{86}$ de proteção à família, e, nesse sentido, protege à mãe e à criança, tanto que é destinado somente ao segurado (empregado ou avulso) de baixa renda, que possua filhos de até quatorze anos ou inválidos, que, por presunção legal, encontra-se mais exposto às vicissitudes da vida para manter sua família. Sua concessão independe de carência e exige, como contrapartida, a comprovação da vacinação dos filhos menores de sete anos e a comprovação da frequência escolar dos filhos entre sete e quatorze anos. $\mathrm{O}$ valor do benefício depende da renda do empregado ou avulso, sendo de $\mathrm{R} \$ 31,22$ por filho

\footnotetext{
${ }^{81}$ Os artigos 71 a 73 da Lei de Benefícios versam sobre o salário-maternidade.

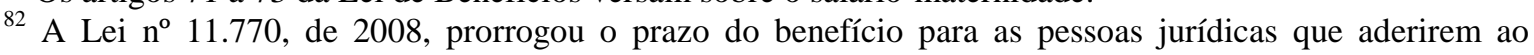
programa Empresa Cidadã, mediante a concessão de incentivo fiscal realizado por meio de abatimento no Imposto de Renda devido pela empresa dos valores pagos à gestante durante o prazo acrescido da licença.

${ }^{83}$ Portaria anual do Ministro da Previdência Social determina os limites máximos do salário-de-contribuição, e a tabela de contribuição do segurado. Para ano de 2012, por força da Portaria 02 de 06/01/2012, o LMSC é de R\$ 3.916,20.

${ }^{84}$ A Emenda Constitucional no 20, de 1998, limitou, por meio do artigo 248 da Carta, o valor do salário maternidade ao valor do vencimento do Ministro do Supremo Tribunal Federal.

${ }^{85} \mathrm{O}$ artigo 93-A do RPS estipula que se a criança tiver até um ano de idade, a licença terá o prazo integral, ou seja, 120 dias. De um ano de idade até 4 anos completos, o prazo será de 60 dias, e se a criança tiver entre quatro anos e até 8 anos, trinta dias.

${ }^{86}$ Lei no 8.213 , de 1991, artigos 65 ao 70 .
} 
de até quatorze anos ou inválido para os segurados que percebam até $\mathrm{R} \$ 608,80$ mensais e de $\mathrm{R} \$ 22,00$ para os segurados que tenham salário entre $\mathrm{R} \$ 608,81$ e $\mathrm{R} \$$ 915,05, recordando que é pago pelo empregador e compensado simultaneamente ao pagamento das contribuições previdenciárias.

Analisemos agora um benefício que tem reprovação social gritante, muito graças à desinformação, o auxílio-reclusão. ${ }^{87}$ Benefício destinado aos dependentes do segurado de baixa renda, ${ }^{88}$ é devido quando o segurado é preso, não havendo percepção de salário nem de aposentadoria ou auxílio-doença. Tem-se como ratio legis a proteção aos dependentes do segurado de baixa renda que se encontrariam totalmente desprovidos de meios de subsistência em face do ilícito cometido por aquele que deveria ser encarregado de provêlos.

Cabe o benefício no caso de prisões que devem ser cumpridas em regime semiaberto e pode ser acumulado com atividade remunerada realizada no estabelecimento prisional. Tem o valor de renda mensal de $100 \%$ do salário-de-benefício e o recebimento é vinculado à comprovação trimestral do recolhimento do segurado, atestada por certidão emitida pelo estabelecimento. É suspenso no caso de fuga, podendo ser restabelecido na recaptura se ainda for mantida a qualidade de segurado. Não é exigida carência para a percepção do benefício, somente a qualidade de segurado. ${ }^{89}$

A proteção contra o desemprego involuntário está prevista no artigo 201, inciso III, da Constituição, sendo um dos eventos cobertos pela Previdência Social. Porém, o segurodesemprego é pago pela Caixa Econômica Federal, a partir de dados registrados pelo Cadastro Geral dos Empregados e Desempregados (CAGED), que é gerido pelo Ministério do Trabalho e Emprego (MTE). Os recursos que suportam este benefício são oriundos do Fundo de Amparo do Trabalhador (FAT), também ligado ao MTE.

Embora tais assertivas, todas corretas, encaminhem nosso raciocínio no sentido de desqualificar o seguro-desemprego do rol dos benefícios previdenciários, devemos recordar que a principal fonte de financiamento do FAT é a contribuição denominada PIS/PASEP, destinada à Seguridade Social, segundo o artigo 195 da Carta de 1988. Sendo o desemprego um dos maiores problemas que afligem o mundo moderno, fica escancarada a necessidade da proteção social quando ele ocorre involuntariamente.

\footnotetext{
${ }^{87}$ Artigo 80 da LB.

${ }^{88}$ Pela Portaria Ministerial no 2 de 06/01/12 é devido o auxílio-reclusão ao segurado que tenha salário-decontribuição de até $\mathrm{R} \$ 915,05$.

${ }^{89} \mathrm{O}$ artigo 15 da Lei $\mathrm{n}^{\circ} 8.213,1991$, dispõe sobre os prazos de manutenção da qualidade de segurado da Previdência Social independentemente do pagamento de contribuições
} 
Por óbvio que é um benefício destinado ao trabalhador empregado e avulso, mas também ao doméstico quando houver o recolhimento do FGTS por conta do empregador doméstico. Consistirá no pagamento de 3 a 5 parcelas, dependendo do período trabalhado por força do último contrato de trabalho, e o rendimento consistirá na percepção do salário médios dos últimos três meses multiplicado por percentuais que dependem da faixa salarial do empregado. A percepção do benefício depende do cumprimento de carência de 16 meses contados a partir da dispensa que deu origem à primeira habilitação, ou seja, a carência para o seguro desemprego depende da existência de relação de emprego, ou de avulso, ou ainda de doméstico com recolhimento de FGTS, por mais de 16 meses.

Por fim, tratemos da pensão por morte. Benefício delineado no artigo 74 e seguintes da Lei $\mathrm{n}^{\mathbf{0}}$ 8.213, de 1991, é destinado aos dependentes do segurado da previdência social em função da sua morte. Ressalte-se que a concessão da pensão por morte independe de o segurado estar contribuindo com a Previdência Social, sendo necessária apenas a existência da relação previdenciária, ou seja, o segurado deve estar mantendo essa condição ou ter cumprido os requisitos para obtenção da aposentadoria por idade, isto é, ter atingido a idade necessária e ter contribuído por 180 meses, mesmo que seu período de graça já tenha expirado.

A caracterização da dependência, em face dos dependentes serem os destinatários do benefício, é de importância capital. Esta caracteriza-se pelo convívio na célula familiar e pela necessidade econômica, ao que a doutrina ${ }^{90}$ chama de dependência jurídica e econômica. A legislação previdenciária chama de dependentes presumidos e comprovados. Esses, podemos entender, são aqueles que necessitam comprovar que vivem às expensas do segurado, e são os pais, o irmão menor de 21 anos e não emancipado, o enteado e o menor tutelado. Aqueles, os presumidos, são os dispensados da comprovação da dependência econômica, são os filhos menores de 21 anos e não emancipados, o cônjuge, o companheiro, o filho incapaz, desde que a incapacidade seja preexistente ao obtido. Nesse sentido, podemos dizer que a pensão por morte é concedida ao dependente, que, comprovando sua dependência, requer o benefício e sua percepção, o que não exclui o direito de outros, que após requererem a pensão e comprovarem a dependência poderão partilhar o valor do benefício.

\footnotetext{
${ }^{90}$ Para maior detalhamento, sugere-se HORVATH Jr., Miguel. Direito previdenciário. $7^{\mathrm{a}}$ ed., São Paulo: Quartier Latin, 2008. p. 163.
} 
Hoje é assente o direito ao benefício para o dependente que vivia em união homoafetiva. O valor da renda mensal do benefício é de $100 \%$ do salário-de-contribuição e sua concessão independe de carência.

Além dos benefícios mencionados, a Previdência Social presta, aos segurados e aos seus dependentes, os serviços de reabilitação profissional e o serviço social. Os serviços de reabilitação profissional, como o próprio nome denota, têm como público-alvo os beneficiários incapacitados, total ou parcialmente, para o trabalho, e visa proporcionar os meios para o reingresso no mercado de trabalho. Já os serviços sociais objetivam esclarecer os segurados e seus dependentes sobre seus direitos e, principalmente, os meios de obtêlos. 


\section{CAPÍTULO 3 - CONCESSÃO DE BENEFÍCIOS PREVIDENCIÁRIOS EM OUTROS ORDENAMENTOS JURÍDICOS}

O conhecimento científico deve ser - em nosso entendimento - compartilhado entre os povos como forma de desenvolvimento humano, para que busquem a necessária igualdade social e econômica, com o respeito devido às diferenças culturais, principal razão da diversidade da raça humana e nesse sentido, fonte permanente de procura pelo conhecimento.

Ao pretendermos analisar questões afetas ao ordenamento jurídico, cabe-nos perquirir outros sistemas, observando as semelhanças e diferenças entre as realidades encontradas e as soluções apresentadas para os problemas, com o esmero de efetuarmos a análise dentro da realidade factual e cultural em que os sujeitos estão inseridos. Tal afirmação decorre da posição de Nelson Mannrich, para quem o estudo do direito comparado se realiza através da imersão do estudioso no sistema social e jurídico afeto ao objeto da análise que se pretende empreender. ${ }^{91}$

Assentados nessas premissas, estudaremos a proteção dos direitos previdenciários do trabalhador no sistema de seguridade social da Itália, da Espanha e de Portugal e procuraremos conhecer, com visão crítica, a realidade dos trabalhadores desses países, tão importantes para a cultura social e jurídica brasileira no tocante ao tema que enfrentamos. ${ }^{92}$

\subsection{Modelo Italiano para a concessão de benefícios previdenciários}

\subsubsection{Breves considerações iniciais: evolução histórica e modelo adotado}

A proteção social na Itália, segundo Cinelli, pode ser considerada expressão, na sua essência, "della naturale vocazione sociale dell'uomo" e dos valores transcendentes que animam suas ações. ${ }^{93}$

\footnotetext{
91 O Professor Nelson Mannrich coordenou os cursos sobre as reformas trabalhistas na Itália, Espanha, Portugal e França, ministrados na Faculdade de Direito da Universidade de São Paulo nos anos de 2008 a 2011 e oferecidos aos alunos da pós-graduação.

92 Participamos dos cursos sobre o ordenamento trabalhista e social da Itália, ministrado pelo professor Alberto Levi, da Università di Modena e Reggio Emilia; da Espanha, ministrado pelo professor Javier Thibault, da Universidad Complutense de Madrid; e de Portugal, ministrado pelo professor Pedro Romano Martinez, da Universidade de Lisboa, nos anos de 2008 e 2009.

93 CINELLI, Maurizio. Il rapporto previdenziale. 4. ed. Torino: G. Giappichelli Editore, 2007. p. 1.
} 
Os fatores que alimentaram o nascimento do Estado Social na Itália são múltiplos e ligados às questões sociais, econômicas e éticas que vieram na esteira da Revolução Industrial na Inglaterra, na metade do século XVIII, causadora de profundas transformações, as quais se refletiram na Itália com atraso de um século.

Uma grande massa de trabalhadores em avançado estado de pobreza, pois expulsa das atividades tradicionais, como a agricultura e a manufatura artesanal, migrou para as cidades em busca de trabalho na indústria emergente. Essa, por sua vez, não se furtou de explorá-la, e nem a utilizar da chamada mezze forze, constituída por mulheres e crianças recém-saídas da primeira infância, não respeitando nenhum limite de jornada, nem condição mínima de saúde ou segurança no trabalho.

Como consequência, o número de acidentes do trabalho e morte decorrentes da penosidade laboral tornou-se um problema social relevante. Tal situação se alastrou e passou a influenciar a opinião pública e fomentar o nascimento do sindicalismo como forma de associação do proletariado, chegando a influenciar a moral cristã, por meio da doutrina social da Igreja.

Tais condições contribuíram para que, na Itália e nos demais países europeus, surgisse e se desenvolvesse o que foi denominado posteriormente legislação social, assim entendido o heterogêneo e complexo ordenamento pelo qual o Estado, forçado a abandonar sua inclinação liberal, passa, ainda que vagarosamente, a tutelar o trabalhador e a sociedade em geral.

Essa proteção surge, inicialmente, com medidas repressivas contra a utilização de maneira fraudulenta das regras do direito civil aplicadas à relação de trabalho, ${ }^{94} \mathrm{e}$ posteriormente, com edição de normas específicas voltadas especialmente para regular o descanso do trabalhador (estipulação do descanso semanal, limitação de jornada diária), e melhorar as condições de trabalho (salubridade e periculosidade). É a chamada fase originária do direito do trabalho, primeira expressão do direito social, como forma de o Estado corrigir as distorções da doutrina liberal, a qual não se responsabilizava pelo risco do trabalho e somente desfrutava do resultado dele.

A evolução vem justamente no sentido da proteção ao risco decorrente do trabalho. A proteção era necessária nos casos em que o trabalhador, como consequência da atividade

\footnotetext{
${ }^{94}$ Importe recordar que nos primórdios da industrialização eram as regras do direito civil que se aplicavam às relações de trabalho. Cf. SÜSSEKIND, Arnaldo. Direito constitucional do trabalho. 3. ed. Rio de Janeiro: Renovar, 2004. p. 14
} 
desenvolvida, como consequência de seu trabalho, via-se privado da possibilidade de produzir renda por incapacidade momentânea ou permanente de prestar serviços.

$\mathrm{Na}$ Itália, essa proteção ficou, inicialmente, a cargo do Estado, uma escolha decorrente de fatores de ordem técnica e econômica, amparada no modelo atuarial adotado na Inglaterra, segundo o qual os prêmios necessários para financiar o modelo protetivo estatal eram calculados com base nos riscos. Além dos motivos técnicos, devem-se considerar os políticos, pois a segurança social associada à gestão pública apresenta característica de controle social.

Em 17 de março de 1898, por meio da Lei n 80, surge a obrigação do empregador industrial de manter um seguro contra acidentes. Essa primeira lei italiana, origem do sistema previdenciário por meio da proteção do trabalhador contra acidentes, é a expressão do princípio do risco profissional, no qual a utilização do critério objetivo da responsabilização pelo dano imputa a quem cabe a maior vantagem pelo trabalho realizado - o empregador - o custo pelo seguro contra os acidentes do trabalho.

Respaldando o acerto do sistema, tempos depois, outras categorias passaram a ter a proteção contra acidentes assegurada. Há visível maleabilidade no sistema assegurativo implementado, por causa da distribuição do ônus do risco decorrente do exercício profissional, inclusive financeiro, entre os agentes e o Estado, este de maneira subsidiária. Tal característica do sistema de seguridade até aqui implantado, a de ser maleável, permite que se utilizem políticas seletivas para distribuição dos ônus decorrentes dos eventos que se pretendem cobrir, daquilo que se pretende proteger.

Essa distribuição leva à característica de solidariedade do sistema, assim entendida a distribuição dos direitos e deveres entre os sujeitos participantes e o Estado, e mais, daqueles a quem se pretende incluir no sistema, uma vez que, na Itália, somente os trabalhadores empregados contavam, a princípio, com proteção previdenciária.

Cinelli ${ }^{95}$ ainda aponta que o modelo adotado, baseado na contribuição calculada em bases atuariais, intercategorial, de associação compulsória, e gerenciamento estatal, ajuda no desenvolvimento também como instrumento de política econômica, quanto mais de política voltada à produção de postos de trabalho. Ainda, segundo o mesmo autor, não se pode esquecer a característica de redistribuição de renda que o modelo apresenta.

Desde o momento que o trabalhador italiano mergulha no desenvolvimento de sua atividade laboral e, para tanto, lança mão de toda sua capacidade, fica exposto a uma série

${ }^{95}$ CINELLI, Maurizio. Il rapporto previdenziale. 4. ed. Torino: G. Giappichelli Editore, 2007. p. 7. 
de riscos os quais não pode cobrir diretamente com seu salário, uma vez que esse se destina ao seu sustento e à manutenção de sua família. Por outro lado, tal risco não pode ser coberto diretamente, até por segurança do próprio trabalhador, pelo empregado. Nesse cenário, segundo Mariani ${ }^{96}$, surge a necessidade de uma previdência social.

A Constituição Italiana estabelece em seus artigos 4, 24, 31, 32, 34 e 38 o delineamento do sistema previdenciário peninsular. Observemos, em linhas gerais, suas disposições.

\subsubsection{Sujeitos da Previdência Social Italiana}

Até recentemente, a previdência social italiana não protegia todos os trabalhadores, todas as formas de atividade produtiva decorrente do trabalho da pessoa física, talvez pela proteção surgir como cláusula acessória do contrato de emprego. ${ }^{97}$ Outras formas de prestação de serviço pelo homem, como o trabalho autônomo, quando encontravam proteção na previdência social, era em decorrência de leis esparsas.

A escolha de incluir no mesmo âmbito de proteção todos os trabalhadores vem representada por leis promulgadas de 1993 até $2003 .{ }^{98}$

O sistema, como visto, contributivo, conta, além da participação do próprio segurado, com a contribuição do datore di lavoro, expressão que contempla, além do empregador, o contratante que mantém trabalhadores sob outros vínculos de trabalho. Ao último cabe o maior ônus previdenciário, o que se justifica pela teoria do risco profissional, origem do próprio sistema previdenciário italiano.

Importante ressaltar que cabe ao empregador o dever de reter e recolher a contribuição do segurado, o que desonera o trabalhador da prova do recolhimento de sua contribuição, uma vez que há substituição de responsabilidade tributária. Tal situação não se aplica ao trabalhador autônomo quando esse não presta serviços para uma empresa,

\footnotetext{
96 GIUDICE, F. del; MARIANI, Federico; SOLOMBRINO, Mariarosaria. Legislazione e Previdenza Social: Manuale Teorico Pratico. 21. ed. Napoli: Simone, 2008. p.301.

97 Cf. CINELLI, Maurizio. Il rapporto previdenziale. 4. ed. Torino: G. Giappichelli Editore, 2007. p. 22

${ }^{98}$ Lei $\mathrm{n}^{\circ}$ 537, de 1993, afeta ao pequeno empresário, ao profissional liberal, ao trabalhador associado. A reforma previdenciária de 1995 delegou ao governo unificar os direitos previdenciários de várias categorias de trabalho autônomo e profissões tradicionais, como advogados, notários, comercialistas, engenheiros, médicos etc. A Lei ${ }^{\circ} 662$, de 1996 , pelos artigos $1^{\circ}, 196^{\circ}, 202^{\circ}$ e $203^{\circ}$, estendeu os direitos previdenciários ao profissional habitual autônomo de vendas em domicílio, aos promotores de serviços financeiros, aos de serviços turísticos e demais atividades de intermediação. O trabalhador que presta serviços autônomos com continuidade e sob coordenação do tomador e o trabalhador a projeto tiveram seus direitos assegurados pelo artigo 61 do Decreto Legislativo $\mathrm{n}^{\circ} 276$, de 2003.
} 
porque, ao assumir o risco de sua atividade, o autônomo se obriga também ao recolhimento de sua contribuição para a previdência social.

Em relação às características específicas do trabalhador parassubordinado, ${ }^{99}$ explicitamos que cabe ao tomador de serviços o dever de reter e recolher a contribuição do trabalhador, além da obrigação do recolhimento de sua quota.

\subsubsection{Eventos cobertos pela Previdência Social e forma de financiamento}

A função da previdência social não é eliminar um dano decorrente da prestação laboral por meio de indenização, e sim atenuar os efeitos de uma situação de necessidade socialmente relevante, ${ }^{100}$ assim entendida a carência de um bem essencial à vida.

Ao se entender que os bens essenciais à vida do trabalhador e de sua família são oriundos do seu trabalho, a função da previdência social se exprime na conservação do nível de renda do trabalhador nos casos em que ele não pode prover seu próprio sustento por meio da prestação pessoal de serviços.

Porém, nem todas as circunstâncias que impedem o trabalhador de gerar renda pelo trabalho são cobertas pela previdência social. Somente o são aquelas em que o risco decorre do exercício do próprio trabalho, previstas pelo legislador, e que diminuem ou eliminam a capacidade pessoal de prestar serviços tendo por consequência prejuízo da remuneração do trabalhador.

Podemos dividir esses riscos, como prega parte doutrina italiana, em três tipos. Em primeiro lugar, existem os riscos relacionados à capacidade de trabalho, os quais ofendem a integridade física do trabalhador, dificultando ou impedindo o desenvolvimento de sua atividade habitual, como os acidentes, doenças profissionais ou não e velhice. Em segundo lugar, há os que influenciam a capacidade de ganho do trabalhador, por exemplo, o

\footnotetext{
99 O parassubordinado é aquele trabalhador que, posicionado entre o trabalho autônomo clássico e o subordinado, presta pessoalmente serviços de maior know-how, por meio de contratos de maior duração, a um único tomador de serviços, o que lhe causa relativa dependência do ponto de vista financeiro. Cf. BULGUERONI, Renata Orsi. Parassubordinação: Origens, Elementos, Espécies e Tutela. In: MANNRICH, Nelson (Coord.). Reforma do Mercado de Trabalho: a experiência Italiana. São Paulo: LTr, 2010. p. 122.

100 Cinelli, nesse ponto, descreve a função da previdência social italiana como "nella reazione ad una situazione di bisogno socialmente rilevante." Em tradução livre: "na reação a uma situação de necessidade socialmente relevante'. (CINELLI, Maurizio. Il rapporto previdenziale. 4. ed. Torino: G. Giappichelli Editore, 2007. p. 30)
} 
desemprego involuntário e diminuição da jornada. Finalmente, há os riscos que decorrem de um aumento da necessidade de renda do trabalhador, como a carência familiar. ${ }^{101}$

Possível, ainda, subdividir os riscos acima em riscos profissionais ou não profissionais. Os primeiros produzem seus efeitos pelo próprio exercício do trabalho, como acidentes do trabalho, desocupação involuntária e doenças profissionais. Os segundos relacionam-se às condições que podem ofender o trabalhador, mas não decorrem diretamente de sua atividade profissional, por exemplo, necessidade familiar, gravidez, velhice e morte. Observamos na Constituição Italiana, no artigo $38,2^{\circ}$ parágrafo, os riscos expressamente assegurados:

Art. 38. Ogni cittadino inabile al lavoro e sprovvisto dei mezzi necessari per vivere ha diritto al mantenimento e all'assistenza sociale. I lavoratori hanno diritto che siano preveduti ed assicurati mezzi adeguati alle loro esigenze di vita in caso di infortunio, malattia, invalidità e vecchiaia, disoccupazione involontaria.(grifo nosso)

Definidos, portanto, os eventos futuros e incertos que o Constituinte Italiano decidiu tutelar: os acidentes, as doenças, a invalidez, a velhice e o desemprego involuntário foram os riscos sociais protegidos. Vejamos agora como ocorre o financiamento da previdência social.

O regime de custeio previdenciário na Itália é fundado na contribuição dos trabalhadores e dos empregadores, não obstante a recente e crescente participação do Estado, por meio de recursos injetados para cobrir o déficit, ou de maior investimento na 'fiscalização do ônus social'. ${ }^{102}$ Obrigação legalmente imposta, a contribuição previdenciária é instaurada desde o momento inicial do desenvolvimento de qualquer atividade laboral remunerada, sendo devida pelo empregador e pelo trabalhador em uma alíquota total, em geral, de $33 \%$ (Lei n ${ }^{\circ} 247$, de 2007). ${ }^{103}$

${ }^{101}$ Cf. GIUDICE, F del; MARIANI, Federico; SOLOMBRINO, Mariarosaria. Legislazione e Previdenza Social: Manuale Teorico Pratico. $21^{\mathrm{a}}$ ed., Napoli: Simone. 2008. p. 310.

${ }^{102}$ Cf. GIUDICE, F del; MARIANI, Federico; SOLOMBRINO, Mariarosaria. ob. cit. p. 312.

${ }^{103}$ Cf. GIUDICE, F. del; MARIANI, Federico; SOLOMBRINO, Mariarosaria. Legislazione e Previdenza Social: Manuale Teorico Pratico. 21. ed. Napoli: Simone, 2008. p.315. 


\subsubsection{Tutelas}

A legislação social na Itália é embasada em normas imperativas e, portanto, desprovida da possibilidade de ser modificada por acordo das partes, mormente no caso de causar desvantagem para o empregado considerado hipossuficiente.

A concretude do aspecto coercitivo das normas sociais apresenta-se na atuação direta do Estado, segundo preceito Constitucional expresso no artigo 117, como "determinazione dei livelli essenziali delle prestazioni concernenti i diritti civili e sociali che devono essere garantiti su tutto il territorio nazionale." 104

Em complemento à competência legislativa exclusiva, adicione-se a atividade de fiscalização por parte de órgãos da Administração Pública, cujo objetivo é prevenir infrações e comprovar, se for o caso, a violação dos ditames legais, tendo como decorrência a aplicação de sanções previstas na mesma lei de âmbito nacional. Por óbvio, tal conduta complementa o sistema de tutela a proteção jurisdicional como salvaguarda dos direitos e interesses individuais.

A violação da legislação social passou na Itália por um processo de despenalização. Várias condutas tipificadas como crime foram transformadas, a partir do advento da Lei ${ }^{\circ}$ 689, de 24/11/81, em ilícito administrativo como, por exemplo, as violações em matéria previdenciária e de assistência social, salvo poucas exceções.

Os Decretos Legislativos números 566 e 758, ambos de 1994, caminharam no mesmo sentido e modificaram o âmbito de sanção de outros ilícitos atrelados à norma trabalhista, prevendo, inclusive, a oferta de comutação de pena de prisão por pena de multa àqueles que permaneceram no âmbito penal. Ressalve-se que condutas ilícitas afetas à saúde e segurança do trabalho não foram contempladas com a alteração, permanecendo sob a égide do direito penal.

São consideradas ilícitos administrativos as condutas cujo descumprimento é sancionado com multas administrativas pecuniárias. ${ }^{105} \mathrm{~A}$ autoridade competente para apreciar tais ocorrências é a Direzione Provinciale del Lavoro, ou o, quando for o caso, o ente previdenciário a quem era devida a contribuição e que teve o pagamento omitido total

\footnotetext{
${ }^{104}$ Em tradução livre: “ $m$ ) determinação dos níveis essenciais das prestações referentes aos direitos civis e sociais que devem ser garantidos em todo o território nacional."

${ }^{105}$ Por exemplo, pode-se tomar a sanção administrativa prevista no caso de lavoro nero (assim entendida a contratação de trabalhador sem a devida formalização), denominada maxisanzione, conforme o artigo 36 bis DL 223, de 2006, convertido na Lei n 248 de 2006.
} 
ou parcialmente. Importante realçar que a Lei $\mathrm{n}^{\circ} 296$, de 2006, quintuplicou a pena prevista para a violação de norma trabalhista, social ou previdenciária.

Os ilícitos civis são aqueles cujas penas preveem ressarcimento ao dano causado, como no caso de violação de caráter formal em matéria de collocamento, ${ }^{106}$ ou no caso de evasão contributiva, ou seja, omissão de pagamento de contribuições previdenciárias. Havendo omissão no pagamento das contribuições, o empregador é sancionado com multa punitiva, com caráter de ressarcimento do dano, pois seu valor é acrescido ao débito tributário. $^{107}$

Além disso, o Código Civil italiano, em seu artigo 2115, prevê que o empregador é civil e penalmente responsável pelo pagamento da contribuição previdenciária, inclusive quanto à parte do trabalhador. Tal disposição embasa a distinção constante da Lei $n^{\circ} 388$, de 2000, que, em seu artigo 116, parágrafo $8^{\circ}$, define omissão da contribuição previdenciária como sendo o inadimplemento, assim entendido a falta de pagamento ou mora, desde que o valor devido esteja declarado ou venha a sê-lo de maneira espontânea, antes de eventual ação fiscal. Porém, não havendo registro dos valores devidos, não sendo esses correspondentes ao valor de fato ou não havendo declaração do montante da contribuição previdenciária, verifica-se a intenção do empregador em não recolher a contribuição previdenciária, isto é, evasão fiscal.

Importa realçar que cabe ao empregador o envio de declaração mensal, denominada DM10, na qual consta o valor devido de contribuição previdenciária. O atraso no envio, ou a omissão desse, são entendidos como sonegação.

A pena pecuniária, portanto sanção civil, é reduzida no caso de omissão, e maximizada no caso de evasão. Na omissão, é de 7,75\% ao ano e limitada, ao máximo, em $40 \%$ do tributo devido, enquanto na evasão é de 30\%, limitada a $60 \%$ do valor da sonegação.

Todavia, havendo mais de uma omissão de registro ou de dever de informação, ou sendo esta prestada com inexatidão, o artigo 37 da Lei $n^{\circ}$ 689, de 1981, imputa pena de dois anos de reclusão se o valor omitido não for inferior ao maior entre os valores de

\footnotetext{
${ }^{106}$ Por collocamento pode-se entender a atividade de intermediação na contratação de empregados. Na Itália, as agências privadas de emprego têm atividade regulada pelo d. legs. 276, de 2003, que prevê uma série de procedimentos específicos para o exercício dessa atividade. Cf. GALANTINO, Luisa. Diritto del lavoro. 15. ed. Torino: G. Giappichelli Editore, 2008. p. 111

${ }^{107}$ Cf. GIUDICE, F. del; MARIANI, Federico; SOlOMBRINO, Mariarosaria. Legislazione e Previdenza Social: Manuale Teorico Pratico. 21. ed. Napoli: Simone, 2008. p. 44.
} 
$€ 2.582$ e $50 \%$ dos valores devidos por mês, incluindo o valor omitido. No caso de omissão dos valores retidos do trabalhador a pena é de três anos de reclusão e multa de $€ 1.032$.

Devemos aqui destacar o reconhecimento da doutrina da dupla característica do dever instrumental de prestar informações ao ente previdenciário e ao órgão estatal de controle, das circunstâncias de fato e de direito que ocorreram no desenvolvimento do contrato de trabalho e que vão desencadear direitos e obrigações ao trabalhador, sob a ótica previdenciária. $^{108}$ Os valores devidos pelo empregador, baseados na remuneração do trabalhador, no tipo de atividade desenvolvida, no número de trabalhadores, no horário de trabalho etc., são informações relevantes para o 'Istituto Nazionale della Previdenza Sociale' (INPS). Porém, tais informações são relevantes também para o empregado, pois seus direitos previdenciários decorrem dos fatos relatados. Em acréscimo, devemos considerar que o trabalhador tem direito ao conhecimento da regularidade do pagamento de suas contribuições previdenciárias, tanto das que lhe foram descontadas, quanto das devidas pela empresa.

Visando facilitar tanto a obrigação da empresa de informar, via DM10, os valores das contribuições previdenciárias devidas, quanto consolidar os direitos dos trabalhadores ao gozo dos benefícios de maneira célere e corretamente calculada, foi publicada pelo INPS, em 25 de maio de 2009, a mensagem 011903, que criou o documento UNIEMENS, documento único que contém as informações do empregador, de todos os trabalhadores que lhe prestaram serviços e o valor das contribuições devidas. Os dados informatizados transmitidos via UNIEMENS são individualizados por trabalhador e se referem não só aos valores da remuneração percebida, como também ao tipo de contrato de trabalho, ao seu início e término, bem como das contribuições retidas e das devidas pelo datore di lavoro.

São os dados constantes do UNIEMENS que, recepcionados pelo sistema do INPS, permitem a concessão dos benefícios previdenciários ao trabalhador italiano.

Cabe destacar que a comprovação da regularidade da empresa no recolhimento das contribuições previdenciárias é efetuada por meio do Documento Unico di Regolarità Contributiva (DURC), previsto no DL n ${ }^{\circ} 210$, de 25/09/2002 e reformado pela Lei $\mathrm{n}^{\circ} 296$, de 2006, que o estendeu a todos os empregadores. Graças ao sistema UNIEMENS, esses dados ficam disponíveis para consulta e, segundo o site do INPS, 109 "tale possibilità

\footnotetext{
${ }^{108}$ CINELLI, Maurizio. Il rapporto previdenziale. 4. ed. Torino: G. Giappichelli Editore, 2007. p. 108.

${ }^{109}$ Disponível em:

<http://www.inps.it/portale/default.aspx?sID=0\%3B5773\%3B6118\%3B6119\%3B6133\%3B\&lastMenu=613

3\&iMenu=1>. Acesso em: 9 dez. 2012.
} 
riveste particolare importanza anche ai fini della verifica della correntezza degli adempimenti contributivi.",110

\subsection{Modelo Espanhol para a concessão de benefícios previdenciários}

\subsubsection{Breves considerações iniciais: evolução histórica e modelo adotado}

A seguridade é um processo social evolutivo, portanto inacabado e inacabável, que se caracteriza pela decisão da sociedade - que influencia o Estado - sobre as formas de proteger o cidadão cuja capacidade de gerar renda pelo trabalho é temporária ou definitivamente diminuída ou cessada.

Na Espanha, o sistema social de amortização de riscos sociais surge a partir das iniciativas populares, relacionadas à ajuda aos necessitados, comumente conhecida por caridade, prestada por entidades religiosas na maioria dos casos.

Inegável a importância da família, inclusive no sistema espanhol, no processo social de assistência. Primeiro e verdadeiro 'colchão' social, a entidade familiar - claro que com variações de intensidade dependendo da cultura dos povos - foi a forma encontrada pelo ser humano para se proteger e garantir o mínimo existencial nas situações de necessidade. Expressa a importância dessa forma de organização o fato de ter influenciado o moderno instituto jurídico civilista do dever de prestar de alimentos. ${ }^{111}$ Tanto as instituições de caridade, quanto a própria instituição familiar, são os mais relevantes exemplos de atenção e assistência às necessidades sociais inespecificamente realizadas.

Em outro giro, as formas organizadas de assistência social na Espanha surgem no início da moderna civilização europeia, na linha das reformas e contrarreformas religiosas, quando a caridade organizada passa a ser exercida pelo Estado, é dizer pelo Rei, principalmente por meio da assistência aos indigentes.

Reflexos desse movimento também surgem em outros países europeus, como por exemplo, na Inglaterra, com a edição da Lei dos Pobres (Poor Law), em 1661; e na França, com a previsão constitucional constante da Carta de 1793, que dizia que o socorro público é dívida sagrada e explicitava que a sociedade devia garantir a subsistência aos cidadãos

\footnotetext{
${ }^{110}$ Em tradução livre: 'tal possibilidade reveste-se de particular importância também com finalidade de se verificar a regularidade da contribuição'

111 Cf. VIDA SORIA, José. Manual de seguridad social. 3. ed. Madrid: Tecnos, 2007. p. 25.
} 
necessitados, assegurando-lhes trabalho ou meios de vida para os que não conseguissem trabalhar.

A beneficência pública caminha nesse sentido, com pequenas variações de Estado para Estado, mirando os casos extremos de pobreza, hoje denominados excluídos socialmente, proibindo a mendicância e se equilibrando sobre a linha tênue que divide a assistência social aos realmente necessitados dos abusos e excessos que a sociedade não tolera, pois não admite sustentar aquele que não quer trabalhar. A Revolução Industrial não muda o posicionamento social, e o Estado Liberal mantém a mesma conduta.

Em 1812, a Constituição Espanhola de Cádiz, por meio de seu artigo 321, determina que os ayuntamientos, as prefeituras, devem cuidar dos hospitais, hospícios e estabelecimentos de beneficência segundo a disposição legal. Em 1822, surge a primeira Ley General de Beneficencia, a qual organiza o sistema e cria uma junta municipal de beneficência, reorganizando a assistência social e introduzindo um sistema solidário territorial, que vigora até 1994. Embora eficiente na maioria dos casos, não apresenta homogeneidade.

O sistema espanhol de beneficência de organização local era extensivo a todos os cidadãos, não só aos trabalhadores assalariados, e financiado pelo poder público, que os protegia de várias contingências, como saúde, acolhimento, meio de vida. Na maioria das vezes, essa proteção materializava-se por prestações e não em dinheiro e não apresentavam continuidade, ou seja, podia ser suprimida a qualquer momento, e principalmente, era destinada aos realmente necessitados, àqueles que possuíssem prova de pobreza, a denominada cartilla de pobre.

O cuidado na concessão dos benefícios era tamanho que, em determinados períodos, aqueles que obtinham os benefícios perdiam seus direitos de cidadania, não podendo, por exemplo, votar enquanto estivessem recebendo as prestações. Por óbvio, o sistema não tinha efetividade social, não obstando desordens sociais e instabilidades políticas, o que não impediu a manutenção da essência do sistema até o segundo terço do século XX, com o início do Estado do Bem-Estar Social.

Entendemos que a evolução da luta contra as mazelas que podem afligir o ser humano se dá pela atribuição ao Estado do dever de proteção do indivíduo submetido a um dos males que se pretende evitar. Não somente a pobreza extrema deve ser afastada, mas também toda a desordem que pode influenciar na vida econômica e social estruturada. 
O próprio nome da ação estatal evoluiu de beneficência social para assistência social, e depois para seguridade social. Essa denominação exprime verdadeira caracterização ao se verificar que a seguridade se fundamenta na técnica típica do seguro, calcada no binômio previsão/provisão, não no campo das relações individuais e sim nas coletivas. Também não pretende a seguridade cobrir os riscos típicos do seguro privado, e sim os riscos sociais, e para tanto, técnicas fundadas no cálculo atuarial para dispersão dos riscos, típicas do seguro privado, são utilizadas em conjunto com outras mais adequadas aos riscos sociais, como a ausência de intenção de obtenção de lucro.

Justamente esta característica da abdicação do lucro fomentou um modelo de organização que se tornou base do sistema de Seguridade Social na Espanha, o mutualismo. As companhias mútuas são organizações voltadas à consecução de objetivos destinados aos seus próprios associados e tendo em vista as especificidades do conceito nos termos em que hoje é entendido, Arco Torres esclarece:

\begin{abstract}
Asociaciones legalmente constituidas, con personalidad jurídica de naturaleza privada asociativa mutual, que debidamente autorizadas por el MTAS, colaboran sin ánimo de lucro y bajo la dirección, vigilancia y tutela de dicho Ministerio, en la gestión de las contingencias de AT y EP, así como en la cobertura de la prestación económica por IT, derivada de contingencias comunes del personal al servicio de los empresarios asociados. $^{112}$
\end{abstract}

As mútuas são, hoje, formadas por empresários de setores econômicos ou profissionais de características similares que buscam distribuir os riscos da cobertura dos eventos ligados às atividades laborais desenvolvidas em suas empresas, entre todos os participantes, sem sofrer o ônus do lucro e de outros eventos indesejados que incidem em outra forma de contratação desses serviços. As mútuas exercem suas atividades com responsabilidad mancomunada de seus associados, tanto em relação aos custos das prestações quanto às eventuais dívidas que venham a ser por elas contraídas.

Características econômicas próprias da Espanha do começo do século XX, marcada por uma industrialização ainda incipiente, atrasaram a efetiva implantação do Sistema de Seguridade Social no ritmo dos países mais desenvolvidos da Europa. Somente durante o franquismo ocorrem os mais significativos avanços em matéria de Seguridade Social.

\footnotetext{
112 ARCO TORRES, Miguel Ángel del; ARCO BLANCO, Ana Isabel del. Diccionário Básico Jurídico. 7. ed. Granada: Comares Editorial, 2009. p. 375
} 
O Fuero del Trabajo, de 1938, marco emblemático do movimento social espanhol, foi seguido pela Lei de Princípios Fundamentais do movimento dos trabalhadores (1958), que continha a declaração dos direitos dos espanhóis à seguridade social. Em 1959, organiza-se o Regimen de los Seguros Sociales Unificados, que convivem, desde logo, com o Mutualismo Laboral e outras instituições não unificadas.

A Lei de Bases, Lei n 193, de 1963, afirmava em sua exposição de motivos que havia chegado o momento para a mudança de um sistema conjunto, porém disperso, de Seguridade Social para um unificado, sem prejuízo da existência de sistemas especiais junto ao sistema geral. Essa lei foi responsável por considerável reforma estrutural no sistema de amortização social da Espanha, a qual atacou a organização do sistema, por meio da redistribuição das prestações sociais, evitando as duplicidades e distorções, e o iminente colapso financeiro, transformando o sistema de capitalização coletiva em sistema repartido (saúde, previdência e assistência) e com cobertura de capitais. Tudo isso com o maior respeito possível às instituições existentes.

Esse respeito permitiu a continuidade das atividades das mútuas patronais privadas, acima mencionadas, o que levou o sistema espanhol à característica que ostenta até hoje da partição da cobertura previdenciária entre as contingências profissionais e as comuns, com o necessário reflexo sobre as contribuições, as quais também são realizadas para entidades distintas.

A doutrina espanhola ${ }^{113}$ entenda ser a Seguridade Social "un derecho constitucional legalmente configurado”, em face do conteúdo da Carta Maior ser composto somente por linhas mestras, dispostas em apenas dois artigos, e com regulação e direitos especificados por meio de lei. O primeiro deles, o artigo 41, descreve as opções jurídicas e sociais que informam e conformam o sistema de seguridade social. ${ }^{114}$ Já o segundo, artigo 149.1.17 , define competência, se do Estado ou das Comunidades Autónomas, para implementar e gerir os serviços que devem ser prestados e a fazer jus à respectiva contribuição, quando for o caso. ${ }^{115}$

Não obstante, deve-se relacionar e acrescer às disposições do artigo 41 da Constituição Espanhola os ditames sobre proteção à família (artigo 39); proteção à saúde

${ }^{113}$ Cf. VIDA SORIA, José. Manual de seguridad social. 3. ed. Madrid: Tecnos, 2007. p. 49.

${ }^{114} \mathrm{Em}$ essência, dispõe o artigo 41 que "los poderes públicos mantendrán un régimen público de Seguridad Social para todos los ciudadanos que garantice la asistencia y prestaciones sociales suficientes ante situaciones de necesidad especialmente en caso de desempleo. La asistencia y prestaciones serán libres".

${ }^{115} \mathrm{O}$ artigo $149.1 .17^{\mathrm{a}}$ preceitua ser competência exclusiva do Estado "la legislación básica y régimen económico de la Seguridad Social, sin perjuicio de la ejecución de sus servicios por las Comunidades Autónomas." 
(artigo 43); deficientes (artigo 49); e pensões às pessoas da terceira idade (artigo 50). Isso porque a doutrina e jurisprudência entendem que as disposições constitucionais constantes dos artigos mencionados têm dimensão mais ampla do que a da Seguridade Social.

O sistema de Seguridade Social Espanhol hoje é regido pelas disposições do Texto Refundido de la Ley General de la Seguridad Social 1/1994 (TRLGSS), ${ }^{116}$ com muitas modificações posteriores. Dentre elas, destacamos a Ley 52/2003, que alterou as disposições relativas ao entendimento sobre os princípios da Seguridade Social, especificando que o sistema - contributivo e não contributivo - baseia-se nos princípios da universalidade, unidade, solidariedade e igualdade. Explicita, ainda, que quaisquer outras prestações de caráter público que venham modificar, complementar ou ampliar as existentes devem se sujeitar aos princípios elencados, respeitando as ajudas de outra natureza que as Comunidades Autônomas, dentro de suas competências, estabeleçam.

O sistema, desde sua origem, é operacionalizado por meio de órgãos especializados que sempre funcionaram de forma descentralizada. Desde o originário Instituto Nacional de Previsión, de 1908, fundado antes mesmo do Ministério do Trabalho, que, com ajuda das mútuas laborais, compôs o embrião do sistema de seguridade espanhol. Hoje, são gestores do Sistema de Seguridade no país o Instituto Nacional de la Seguridad Social (INSS), o Serviço Pùblico Estatal de Empleo (INEM), o Instituto de Mayores y Servicios Sociales (IMSERSO) e o Instituto Nacional de Gestión Sanitaria (INGESA). Esses são aliados a inúmeras entidades gestoras de regimes especiais e aos Serviços Comunes de la Seguridad Social, e compõem o sistema.

Em síntese compatível com o escopo do presente estudo, devemos apontar que cabe ao INSS gerir as prestações econômicas do Sistema de Seguridade, exceto os benefícios relacionados às aposentadorias e aposentadorias por invalidez devidas pela Assistência Social e ao seguro desemprego. Ressalte-se que, quanto aos benefícios relacionados às incapacidades laborais, cabe ao INSS a administração completa, incluindo a gestão, valoração, qualificação e revisão da incapacidade, assim como a determinação das responsabilidades das mútuas e das empresas. Tal ressalva se deve à característica do sistema que permite ao empresário a escolha de quem vai assumir seus riscos profissionais, se uma Mútua ou o INSS, o que define o sujeito credor de sua obrigatoriedade de cotização. $^{117}$

\footnotetext{
${ }^{116}$ Deve-se mencionar que o TRLGSS sofreu alterações pela Lei 2/2004, Ley 39/2006 e 40/2007.

117 Art. 70 da LGSS. Cf. GABINETE JURÍDICO DEL CENTRO DE ESTUDOS FINANCEIROS. Lecciones del Seguridad Social. Madrid: Ediciones CEF, 2011.p. 43.
} 
Atuam em colaboração aos órgãos gestores da Seguridade Social aqueles denominados pela Lei de Bases como órgãos colaboradores, assim entendidas as Mútuas empresariais e as empresas e entidades que firmam convênio, no âmbito do Sistema Nacional de Saúde, com os respectivos órgãos gestores. A regulação das atividades das mútuas, inclusive quanto à conceituação, requisitos de formação e funcionamento, constam dos artigos 68 a 76 da LGSS.

Contextualizados os aspectos mais relevante do sistema de bem-estar espanhol, observemos seus sujeitos e, a seguir, a implantação dos seus objetivos e a forma de financiamento.

\subsubsection{Sujeitos da Previdência Social Espanhola}

A Constituição Espanhola, em seu artigo 41, acima citado, determina a proteção de todos os cidadãos pela Seguridade Social, revelando o caráter universal do sistema. Por se saber que nem sempre é possível o cumprimento, em sua inteireza, do preceito constitucional, cabe a delimitação do campo subjetivo de aplicação do sistema. Essa delimitação é realizada pela existência ou não de contribuição pelo destinatário da proteção.

A contribuição é obrigatória e decorrente do preenchimento da condição prescrita em lei, no caso, a existência do exercício de um trabalho pela pessoa física, ou, como define a doutrina espanhola, o critério profissional. Segundo o artigo 7.1 da Lei Geral de Seguridade Social, TRLGSS, são incluídos no sistema contributivo tanto os espanhóis quanto os estrangeiros que se encontrem legalmente na Espanha e realizem ali suas atividades econômicas que, por força de lei, ensejem a proteção, seja no regime geral, seja em especial.

Além do critério pessoal, ser espanhol ou estrangeiro em situação regular, o exercício da atividade remunerada é requisito essencial para a proteção e, por via de consequência, para a contribuição. Enquadram-se nesta condição não só os trabalhadores empregados, mas também os sócios trabalhadores de sociedades mercantis, os autônomos, cooperados, funcionários públicos e estudantes, ${ }^{118}$ enfim praticamente a totalidade dos trabalhadores remunerados, excluindo-se os trabalhadores do âmbito doméstico - que devem ser enquadrados em regime especial, o dos trabalhadores autônomos - e os

\footnotetext{
${ }^{118}$ Muito embora os estudantes não sejam considerados trabalhadores em sentido estrito, a proteção a eles se estende por serem potenciais segurados, segundo o ordenamento.
} 
trabalhadores esporádicos - aqueles que não têm habitualidade nem caráter profissional. Em adendo deve-se apontar o caráter territorial como requisito, ou seja, trabalhar na Espanha.

Importa ressaltar, embora não seja o objeto do presente trabalho, que o regime não contributivo exige, como condição de acesso aos benefícios, além dos requisitos pessoais e territoriais, a comprovação do estado de necessidade, como é típico dos regimes assistencialistas.

Finalizando este tópico, devemos apontar o dúplice enquadramento do empresário no sistema de seguridade espanhol. Sujeito de direitos, por vezes na categoria de trabalhador por conta própria, também a ele é imputado o caráter de obrigado, ${ }^{119}$ uma vez que o empresário é pessoalmente responsável pelas cotizações, pelas dívidas das mútuas, quando a elas associado, e pelas obrigações acessórias do dever de informação da afiliação, altas e baixas ${ }^{120}$ dos trabalhadores por ele contratados, junto aos respectivos regimes que compõem a seguridade espanhola.

\subsubsection{Eventos cobertos pela Previdência Social e forma de financiamento}

As contingências, assim entendidas as situações de necessidade social, cobertas pela Seguridade na Espanha, são aquelas reconhecidas como riscos ao ordenamento social e, por vontade do legislador, cobertos pelo manto da proteção de um benefício social. Como visto, para que o cidadão tenha direito a esse benefício, pode ser ou não exigida uma contribuição prévia obrigatória, o que denotaria, na ausência de contrapartida contributiva, o caráter assistencial daquela benesse estatal.

Por benefício social, na Espanha, pode-se entender a prestação que visa suprir, ao menos parcialmente, uma despesa incorrida ou a complementação de uma renda não

\footnotetext{
${ }^{119}$ Art. 99.3 da LGSS e artigo 10 do Real Decreto 84/96.

${ }^{120}$ O sistema no cadastro da Seguridade Social Espanhola é realizado para a empresa pela sua inscrição. É um dever legal que a empresa deve cumprir no momento em que inicia suas atividades. Segundo o artigo 99.2 da LGSS, a inscrição deve ser realizada no nome do titular da empresa, pessoa física ou jurídica. Quanto aos trabalhadores, três são os movimentos com impacto cadastral que devem ser informados pelo empregador. O primeiro, a afiliação, é o ato administrativo de admissão ao sistema único, válido para toda vida laboral da pessoa física, que deve ser realizado na primeira vez que essa pessoa pratica uma atividade determinante de sua inclusão. O trabalhador dito por conta alheia, o empregado, é afiliado por meio da informação da empresa. Aquele que trabalha por conta própria deve tomar providências para que se realize o ato. $\mathrm{O}$ segundo, a alta que, no sistema espanhol, significa o exercício da atividade ensejadora da proteção estatal pela pessoa física e deve ser informada no primeiro dia de trabalho na empresa. Por fim, a baixa que é a exclusão da pessoa física pela extinção da relação de trabalho que ensejou a alta que se desenvolvia, sendo também obrigação da empresa informá-la.
} 
recebida. Tal decréscimo de renda, ou aumento de despesa, tem que decorrer de um evento, anteriormente tido como possível ou provável, tecnicamente denominado contingência, e que foi o causador da necessidade socialmente relevante que se pretende reparar pelo seguro estatal.

Por vezes, devemos esclarecer, a situação protegida não é objeto somente de um benefício em dinheiro, demandando para sua superação outras prestações específicas, como, por exemplo, no caso da necessidade de uma reabilitação ou atendimento médico. Tais prestações, ditas em espécie, também são objeto da Seguridade Social. As ações protetoras da Seguridade Espanhola constam dos artigos 114 e seguintes da Lei Geral de Seguridade Social.

Reiteradamente, ao longo do estudo do sistema ibérico de seguridade, apontamos a distinção quanto à origem da contingência ensejadora da proteção, se profissional ou não, uma vez que as prestações decorrentes dos riscos profissionais, além de apresentar melhor conteúdo, ensejam responsabilidade objetiva do empresário quanto aos custos por meio das mútuas. Essas estão previstas no artigo 115 e 116 da Lei Geral.

O artigo 117 da LGSS trata dos acidentes e doenças comuns, com remissão ao artigo posterior, o 118, para as regulações específicas sobre os infortúnios que não decorrem do risco laboral. Em ambos, prevê-se a cobertura por morte, incapacidade temporária e permanente, maternidade, gravidez de risco, aposentadoria por tempo de serviço, desemprego, morte e encargos familiares. Por óbvio, e em face da distinção acima apontada, há cobertura para a incapacidade temporária e permanente, invalidez e morte decorrente dos riscos profissionais. O principal risco profissional é o acidente do trabalho, que, por sua relevância dentro do sistema espanhol, é legalmente conceituado e apresenta três características essenciais. A primeira, ocorrer lesão corporal, entendida assim qualquer alteração da integridade física ou psíquica do trabalhador resultante de uma ação de caráter súbito ocorrido no ambiente de trabalho; a segunda, ser o acidentado trabalhador empregado; já a terceira, haver nexo causal entre o trabalho e a lesão.

A cobertura dos benefícios previdenciários acima descritos, como é típico em um regime com financiamento público de seguridade que se pretende sólido e viável, não deve extrapolar os aportes fiscais realizados pelo Estado e pelas contribuições obrigatórias realizadas pelos sujeitos envolvidos na relação de trabalho, base do sistema de amortização social. O artigo 68 da LGSS enumera os diferentes recursos para esse financiamento. 
Dentre as fontes de custeio do sistema, as contribuições das empresas e dos trabalhadores respondem por dois terços da arrecadação, sendo, portanto, as principais. Prevista na LGSS e regulamentada pelo Real Decreto 2064/1995, com as alterações posteriores, as contribuições são devidas pelos trabalhadores e empregadores, exceto no caso da cotização sobre os acidentes do trabalho e doenças profissionais, que correm somente por conta dos empregadores. O empresário assume uma posição especial como substituto do empregado, uma vez que é o responsável pela obrigação de reter e recolher a contribuição do trabalhador, além do recolhimento da sua quota. Em função dessa posição especial, o empresário é responsável solidário pelo recolhimento da totalidade das contribuições, respondendo penalmente pelas retidas e pelas não recolhidas, além de estar a seu encargo o cumprimento das demais obrigações.

A obrigação de pagamento das contribuições surge com a prestação dos serviços, perdurando durante todo o período de seu desenvolvimento e se mantendo inclusive nos casos de incapacidade laboral temporal, gravidez, licença maternidade e paternidade, períodos reservados à amamentação e períodos de suspensão do contrato de trabalho. Suspende-se o dever de cotização nas greves e ausência de atividade empresarial legalmente prevista. Encerra-se o dever de contribuição com a cessação do contrato de trabalho e respectiva baixa do empregado junto ao INSS.

As bases sobre as quais incidirão as alíquotas de contribuição são as parcelas remuneratórias, assim entendida a remuneração total percebida pelo trabalhador, qualquer que seja sua denominação, em razão do trabalho prestado. Sendo a remuneração entendida como a contrapartida do trabalho prestado, as parcelas de natureza indenizatória ou compensatória não integram a base de cálculo da contribuição previdenciária. A Lei $\mathrm{n}^{\circ} 35$, de 2006, em seu artigo 43, relativa ao Imposto sobre a Renda das Pessoas Físicas (IRPF), especifica como verbas salariais (integrando, portanto a base de cálculo da contribuição), dentre outras, as seguintes: utilização de casa; utilização de veículos; os empréstimos tomados com juros inferiores ao do mercado; os pagamentos feitos a título de manutenção, hospedagem, viagens e similares, exceto as realizadas a trabalho; o pagamento de prêmios de contrato de seguros; o pagamentos de bolsas de estudo do trabalhador ou familiares até o quarto grau; e o pagamento de previdência privada. As horas extraordinárias, embora com nítido e cediço caráter salarial, não têm sua contraprestação remuneratória inserida na base de cálculo das contribuições, exceto nos casos de contribuição para financiamento dos 
riscos profissionais, ou para setores em que a prorrogação de jornada seja característica da atividade.

A base de cálculo fica limitada a valores mínimos e máximos, denominados topes variáveis de acordo com a atividade profissional que o trabalhador exerce, segundo tabela publicada anualmente. ${ }^{121}$ As alíquotas aplicáveis sobre a base encontrada dependem do tipo de cotización para a qual se está contribuindo, a saber:

Contingências comuns: $28,3 \%$, sendo $23,6 \%$ de responsabilidade da empresa e 4,7\% a ser descontado do trabalhador;

$\checkmark$ Contingências decorrentes de acidentes de trabalho e enfermidade profissional: aplicar-se-ão as alíquotas constantes da Tarifa de Primas, estabelecida na disposição final oitava da Lei $\mathrm{n}^{\circ} 26$, de 2009, do Pressupostos Gerais do Estado para o ano de 2010;

$\checkmark$ Para os adicionais de hora de extras: 14\%, sendo $12 \%$ suportados pela empresa e $2 \%$ pelo trabalhador;

$\checkmark$ Para o seguro desemprego: as alíquotas dependem do tipo de contrato de trabalho existente, variando de $7,05 \%$ a $9,30 \%$.

Inúmeras outras alíquotas são aplicáveis às contingencias de arrecadação conjunta, que incluem Fondo de Garantía Salarial y Formación Profissional (FOGASA), cuja análise foge da pretensão de contextualização que se pretende neste momento de nosso estudo. ${ }^{122}$

Porém, o valor da contribuição ao sistema de seguridade espanhol não é obtido com a simples multiplicação da alíquota sobre a base de cálculo. Isto porque o sistema de previdência social, por ter custo elevado, é usualmente utilizado como parte de uma

${ }^{121}$ Em 2011, a tabela utilizada foi a seguinte:

\begin{tabular}{|l|l|l|l|}
\hline $\begin{array}{l}\text { Grupo de } \\
\text { cotização }\end{array}$ & Categorias profissionales & $\begin{array}{l}\text { Bases mínimas } \\
(€ / \text { ês })\end{array}$ & $\begin{array}{l}\text { Máximas } \\
(€ / \text { mês })\end{array}$ \\
\hline 1 & Ingenieros y Licenciados. Personal de alta dirección & $1.045,20$ & $3.230,10$ \\
\hline 2 & Ingenieros técnicos, Peritos y Ayudantes titulados & 867,00 & $3.230,10$ \\
\hline 3 & Jefes Administrativos y de Taller & 754,20 & $3.230,10$ \\
\hline 4 & Ayudantes no titulados & 748,20 & $3.230,10$ \\
\hline 5 & Oficiales Administrativos & 748,20 & $3.230,10$ \\
\hline 6 & Subalternos & 748,20 & $3.230,10$ \\
\hline 7 & Auxiliares Administrativos & 748,20 & $3.230,10$ \\
\hline & Categorias profissionales & Mínimas (€/dia) $)$ & Máx (€/dia) \\
\hline 8 & Oficiales de primera y segunda & 24,94 & 107,40 \\
\hline 9 & Oficiales de tercera y especialistas & 24,94 & 107,40 \\
\hline 10 & Peones & 24,94 & 107,40 \\
\hline 11 & Trabajadores menores de 18 años, cualquier & 24,94 & 107,40 \\
\hline
\end{tabular}

122 Para maiores esclarecimentos, cf: GABINETE JURÍDICO DEL CENTRO DE ESTUDOS FINANCEIROS. Lecciones del Seguridad Social. Madrid: Ediciones CEF, 2011. p.157 - 165. 
política de geração de emprego. Tal política é normalmente realizada por meio de uma redução do custo de contratação de mão-de-obra ou da contratação de tipos específicos de trabalhadores, com vistas à inserção no mercado de trabalho ou mesmo seu fomento. Estas reduções, verdadeiros incentivos fiscais, o que denota sobremaneira o caráter tributário das contribuições, ${ }^{123}$ são denominadas bonificações.

As bonificações podem ser realizadas através de um coeficiente reductor. Por exemplo, o previsto no artigo 114.2 da LGSS, com as especificações constantes da Disposición Adicional 27 $7^{\mathrm{a}}$ LSS, aplicável nos casos de conselheiros e administradores de sociedades mercantis, que não são cobertos por seguro desemprego, ou ainda nos casos de empresas colaboradoras voluntariamente com a Seguridade Social. ${ }^{124}$

As bonificações em si, assim entendidas aquelas para fomentar políticas sociais, estão elencadas nas normas regulamentadoras das próprias leis que estabelecem tais políticas, consoante a previsão geral constante do artigo 17 do RD 2.064, de 1995. Ressalte-se a previsão de bonificações ou recargo, conforme o caso, das quotas por riscos profissionais para incentivar a melhora da segurança no trabalho, dada sua relevância social. $^{125}$

\subsubsection{Tutelas}

As proteções aos interesses da seguridade social, ramo do direito que apresenta dupla natureza, tributária e social, têm, igualmente, dupla finalidade: assegurar o ingresso de recursos destinados ao financiamento dos direitos oriundos da atividade laboral e tutelar o direito em si, ou seja, proteger o trabalhador, o que se consubstancia na percepção dos benefícios que a lei lhe outorgou.

Analisando em primeiro lugar a tutela dos aspectos tributários, encontraremos um esforço do legislador espanhol no sentido do adimplemento da obrigação de cotização pelo empresário e para a valorização do cumprimento das obrigações acessórias.

O recolhimento dos valores devidos à Seguridade Social deve ser realizado em ato único e no mês seguinte ao da ocorrência do fato gerador. Inúmeros são os requisitos

\footnotetext{
${ }^{123}$ Cf. VIDA SORIA, José. Manual de seguridad social. 3. ed. Madrid: Tecnos, 2007. p. 189.

${ }^{124}$ Entidades colaboradoras do Sistema de Seguridade Social Espanhol, como visto linhas atrás, ao final do item 3.2.1.

${ }^{125}$ Tais determinações se aproximam das disposições brasileiras constantes da Lei $\mathrm{n}^{\circ} 10.666$, de 2003 , que alterou o artigo 202-A do Regulamento da Previdência Social, aprovado pelo Decreto ${ }^{\circ} 3.048$, de 1999, e criou o Fator Acidentário de Prevenção (FAP).
} 
formais para que a empresa possa efetuar o pagamento, ${ }^{126}$ hoje substituídos pelo uso do meio informatizado denominado Sistema RED, meio obrigatório segundo a Disposición Adicional $5^{\mathrm{a}}$ del RD 1.415/2004.

Com natureza jurídica de confissão de dívida tributária, mesmo valor jurídico emprestado aos documentos físicos que até poucos meses atrás eram exigidos, o sistema informatizado permite não só que a Tesouraria Geral da Seguridade Social (TGSS) inicie os procedimentos arrecadatórios das contribuições, como também permite a constatação de que o trabalhador se encontra em período de alta, ou seja, que ele mantém um contrato de trabalho em vigor e, portanto, se insere no sistema de seguridade social contributiva.

Enviado o RED e recolhida a contribuição, extingue-se a obrigação previdenciária daquele empregador. Porém, em caso de ausência de recolhimento no prazo, mesmo que ainda dentro de período para o recolhimento voluntário, a TGSS abre um 'procedimento recaudatório', concedendo novo prazo para recolhimento pela empresa. O recolhimento em novo prazo será acrescido de multa de $3 \%$ se ocorrer em 30 dias do prazo do vencimento, variando ao longo do tempo em até $35 \%$, se vencido o novo prazo concedido pela fiscalização. Não ocorrendo o recolhimento voluntário, situação que se denomina situación de descubierto, será iniciado o procedimento executivo de cobrança, procedimento coercitivo, que decorre da expedição da certificación de descubierto.

Porém, independentemente do processo executivo, a Seguridade Social dispõe de outras medidas para assegurar seus créditos, com dito acima, inclusive incentivando o adimplemento pontual. O inadimplemento das cotas da seguridade social impede à empresa o gozo de qualquer ajuda ou subvenção. Em âmbito estritamente punitivo, a inadimplência das contribuições, a obtenção indevida das devoluções ou o aproveitamento de bonificações ou deduções indevidas, com ânimo fraudulento, é tipificado como crime de fraude contra a Seguridade Social, segundo o artigo 307 do Código Penal. Destacamos também a imputação da responsabilidade pessoal e objetiva do empregador, no caso de mora com as contribuições devidas em função dos riscos profissionais, além da responsabilidade pessoal pelo inadimplemento das obrigações.

Quanto às medidas destinadas à proteção do crédito da Seguridade Social como forma de incentivar o cumprimento correto e tempestivo das contribuições, devemos

\footnotetext{
${ }^{126}$ Segundo o artigo 57 da TGSS, o recolhimento deve ser realizado diretamente na Tesouraria Geral da Seguridade Social, ou em bancos ou outros estabelecimentos conveniados, mediante a apresentação de um boletín de cotización, mod. oficial TC, que identifica o empresário responsável, os dados do regime de seguridade, a entidade colaboradora dos riscos profissionais, e demais dados necessários para determinar a dívida. Acresce-se ao exposto uma relação nominal dos trabalhadores em modelo oficial, TC-2.
} 
ressaltar a simplificação dos procedimentos necessários para o recolhimento das quotas, pelas empresas e equiparados, com a adoção do sistema RED.

Inequívoca a intenção do legislador em obter os dados que embasam o recolhimento das contribuições de maneira informatizada. Ao lado de diversas formas facultativas de recolhimento, existentes no passado recente, hoje, com a implantação do RED, o sistema informatizado se torna obrigatório, salientando ainda que a falta de informações caracteriza a sonegação tributária.

O descumprimento do dever de prestar informações pelo sistema também impede que a empresa se beneficie das reduções dos valores das contribuições representados pelas bonificações ou quaisquer outros benefícios nas bases de cálculo, tipos ou quotas a serem recolhidas, além de suspender os eventuais benefícios ou parcelamentos concedidos. Em acréscimo, não será analisado nenhum pedido de concessão de qualquer incentivo ou vantagem na valoração das quotas contributivas se o requerente não tiver aderido ao sistema RED.

Havendo tempestiva e correta informação dos dados por meio do sistema RED, ainda que sem recolhimento dos valores devidos à Seguridade Social, a empresa poderá utilizar as bonificações a que possa ter direito, desde que solicite parcelamento desses valores dentro do prazo de pagamento. ${ }^{127}$ No caso do inadimplemento do dever de informar, ou sendo esse prestado de forma intempestiva, a empresa perderá o direito à redução.

Por fim, cabe realçar que os deveres de afiliação, alta e baixa do trabalhador, hoje necessariamente realizados pelo sistema RED, quando descumpridos, importam em responsabilidade do empresário pelas eventuais prestações a que tenha direito o segurado. Quanto à baixa, sua não comunicação ou comunicação indevida mantém a responsabilidade de empresa pelo consequente recolhimento da contribuição.

As medidas acima, nítidas sanções positivas, favorecem os empresários, na medida da simplificação de suas obrigações, e os trabalhadores, que têm sua condição previdenciária reconhecida de plano pelo Estado Espanhol.

\subsection{Modelo Português para a concessão de benefícios previdenciários}

${ }^{127}$ Cf. GABINETE JURÍDICO DEL CENTRO DE ESTUDOS FINANCEIROS. Lecciones del Seguridad Social. Madrid: Ediciones CEF, 2011. p.222. 


\subsubsection{Breves considerações iniciais: evolução histórica e modelo adotado}

Em Portugal, durante o período que compreende do século XII ao XV, a assistência social era prestada por instituições de beneficência ligadas à Igreja, tal qual ocorria na Espanha, e com destinações específicas, como hospitais, hospícios, gafarias (instituições destinadas ao tratamento dos leprosos), albergarias e mercearias (albergues de mulheres idosas). No final do século XV, as Irmandades de Misericórdia absorvem os hospitais, as gafarias e as mercearias.

A evolução do modelo produtivo, como vimos no tocante à Espanha, e os efeitos da Revolução Industrial e do modelo de Estado Liberal, que geraram uma conjuntura perniciosa para o trabalhador no tocante à saúde e segurança no ambiente de trabalho, motivaram, também em Portugal, o início da fase institucional da assistência social, uma vez que essa passa a ser prestada pelo empregador, em regime de associação normalmente formada por vínculo profissional, passando posteriormente pela intervenção do Estado.

Em 1807, registra-se a criação do primeiro Montepio, versão lusitana das mútuas espanholas. Em 1850, com a fundação do jornal Ecco dos Operários, inicia-se o movimento associativo das classes trabalhadoras. Anos depois, em 1891, surgem as primeiras normas sobre associações de socorros mútuos, por meio de Decreto de 28 de fevereiro daquele ano. Oito anos depois, com a Lei de $1^{\circ}$ de agosto de 1899 , passa a ser permitido às associações de classe que criem associações de socorros mútuos e caixas econômicas ou sociedades cooperativas, que objetivam a criação de fundos financeiros para financiar os riscos profissionais.

No início do século XX, sob a influência das ideias de Bismark, ${ }^{128}$ é promulgada a Constituição Alemã de Weimar, que determinava a obrigatoriedade do Estado de prover a subsistência do cidadão que não pudesse realizar uma atividade produtiva, além da instituição de um regime de seguro social contributivo que atendesse as necessidades oriundas de situação de contingências de saúde, maternidade, capacidade laboral e velhice.

Esse cenário internacional, que vai culminar no Estado do Bem-Estar Social do pós-guerra, em Portugal, tem o seguinte paralelo: em 1913 é instituída, pela Lei nº 83, de 24 de julho, a responsabilidade patronal por acidentes de trabalho, o que denota a adoção

\footnotetext{
${ }^{128}$ Otto von Bismark (1815-1898), chanceler alemão, criou o programa social pelo qual o Estado devia promover positivamente o bem-estar de todos os seus cidadãos, por meio de uma série de seguros sociais. Além do cunho social da medida, era inegável seu interesse político, uma vez que visava impedir o crescimento dos movimentos socialistas, favorecidos pela crise industrial.
} 
do princípio do risco profissional. Em 1919, são criados por meio de quatro decretos editados no dia 10 de maio (Decreto $\mathrm{n}^{\mathrm{o}} 5.636$ e seguintes) - sem, entretanto, chegar a funcionar - seguros obrigatórios contra doença; desastres do trabalho; invalidez, velhice e sobrevivência; bolsas sociais de trabalho; e mais, foi também criado, pelo Decreto $\mathrm{n}^{\circ}$ 5.640, o Instituto de Seguros Sociais Obrigatórios e Previdência Social. Somente em 1935, por meio da Lei $n^{\circ} 1.884$, é consagrada a base geral de organização da previdência; tal diploma passa a ser conhecido como Estatuto Geral de Previdência, que visa proteger os trabalhadores da indústria e dos serviços e estruturado em função do Estatuto Geral do Trabalhadores, criado pelo DL no 23.048, de 1935. A Caixa de Reforma ou Previdência é regulamentada pelo Decreto $\mathrm{n}^{\mathrm{o}} 28.321$, de 27 de dezembro de 1937. Em 1940, mais um passo, agora com a instituição da obrigatoriedade de seguro para o meio rural, por meio das casas do povo (DL 30.710, de 1940). Por fim, a generalização do seguro social para os trabalhadores da indústria e dos serviços em 1943.

Auge das ideias protetivas sobre a obrigação do Estado em prover o bem-estar de todos, o período pós-guerra, especialmente até a crise do petróleo de 1973, é rico em medidas que incrementassem os direitos sociais. Em Portugal, junho de 1962, temos a integração dos objetivos e realizações da previdência no plano de política social, denominado por muitos segunda geração da previdência social, instituído pela Lei $\mathrm{n}^{\mathbf{o}}$ 2.115. ${ }^{129}$ Em 1965, vem a consagração do regime de acidentes do trabalho e doenças profissionais, pela Lei $\mathrm{n}^{\circ}$ 2.217, e a aprovação do Regulamento Geral das Caixas de Reforma ou Previdência Social, pelo Decreto $n^{\circ}$ 46.548. Os trabalhadores rurais têm, por meio da Lei ${ }^{\circ} 2.144$, de 1969, a reorganização de sua previdência.

Já em 1974, se inicia a atribuição de prestações não contributivas, com o advento do Decreto Lei $n^{\circ} 217$. Ponto alto do direito da segurança social ocorre em 1976, com a constitucionalização desse, por meio do artigo 63 da Carta da República Portuguesa. Em 1984, se protegem a maternidade e a paternidade, por meio da Lei $\mathrm{n}^{\circ} 4$, e se consagra o sistema de segurança social, por meio da Lei da Segurança Social, de 14 de agosto, Lei ${ }^{\circ}$ 28. A vez das pessoas portadoras de necessidades especiais chega somente em 1989, pois a Lei $\mathrm{n}^{\circ} 9$ determina as medidas de prevenção, reabilitação e integração dos deficientes. Os anos 2000 são caracterizados por legislação de base $^{130}$ do Sistema de Seguridade Social Português.

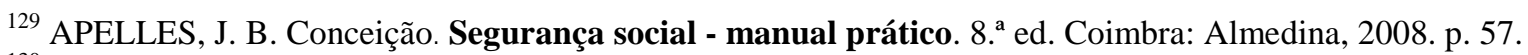

${ }^{130}$ Lei no $^{\circ}$ 17/2000; Lei no 32 de 20 de dezembro de 2002 e Lei no 4 de 2007, denominada Lei de Bases.
} 
Inegável, por todo o exposto, o cipoal da legislação e a profusão normativa que versa sobre o tema. Analisando a questão, Nazaré da Costa Cabral lembra a característica da legislação da segurança social, que é a mutabilidade, "a constante adaptação às novas realidades e vicissitudes." 131 Os percalços são causados pela conjuntura econômica, que influencia as receitas sociais. De um lado, as diminui pela redução da atividade econômica e da massa salarial, e de outro, infla as despesas sociais por causa da diminuição dos empregos e das despesas das famílias com alimentação, saúde e moradia.

Em acréscimo, devemos recordar as vicissitudes demográficas que impactam a velha Europa. Velha não só em história e cultura, mas também em idade de sua população, que há anos tem um baixíssimo crescimento populacional, com fortíssimo impacto, tanto na fonte de custeio do sistema, uma vez que o contingente de trabalhadores jovens diminui, quanto nas despesas, que se avolumam em uma população com idade média mais elevada.

Nesse cenário, as perspectivas para o século XXI, segundo Apelles, passam pela desconfiança da capacidade do Estado de gerir o sistema de Segurança Social, uma vez que há dificuldade de adaptação dos modelos de proteção social aos novos tempos de redução de recursos financeiros, de fontes de financiamento do modelo de Estado Europeu, além das dificuldades demográficas. ${ }^{132}$ Tais desconfianças podem levar a um retorno à corporativização ou grupalização das medidas de proteção, ou seja, as próprias empresas passarem a se encarregar das medidas sociais, pois elas podem, com mais eficiência, utilizar essas atitudes protetivas como instrumento de gestão de seus recursos humanos. ${ }^{133}$ Enfim, surgem novas propostas de modelo de proteção mais eficientes, como por exemplo, os "híbridos sociais", assim entendido o modelo misto, parte pública, parte privada, aproveitando-se a eficiência do particular dentro da regulação do poder público.

O Estado Português, preocupado com sua condição financeira desfavorável e buscando agir como indutor da economia em movimento anticíclico e controlar seu déficit, optou por uma maior segurança jurídica em termos de legislação social. Para isso, adotou, por meio da Lei $\mathrm{n}^{\circ} 110$, de 16 de setembro de 2009, o Código dos Regimes Contributivos do Sistema Previdencial de Segurança Social, que, por força da Lei $n^{\circ} 119$, de 30 de dezembro de 2009, entrou em vigor em $1^{\circ}$ de janeiro de 2011. Fruto de concertação social, vez que celebrado em sede da Comissão Permanente de Concertação Social, o Código

\footnotetext{
${ }^{131}$ Cf. CABRAL, Nazaré da Costa. Contribuições para a Segurança Social: Natureza, Aspectos de Regime e de Técnica e Perspectivas de Evolução num Contexto de Incerteza. Coimbra: Almedina, 2010. p. 6.

${ }^{132}$ Cf. APELLES, J. B. Conceição. Segurança social - manual prático. 8. ${ }^{a}$ ed. Coimbra: Almedina, 2008. p. 58.

${ }^{133}$ Cf. APELLES, J. B. Conceição. ob.cit. p. 59.
} 
Contributivo teve como origem o Acordo Tripartido sobre Reforma da Segurança Social e vem alicerçar a legislação social contributiva, garantindo, mesmo nos difíceis tempos atuais, um corpo normativo integrado, sistematizado e coerente. ${ }^{134}$ Por causa dessa sistematização e coerência, passaremos a utilizar os ditames do código para analisar o modelo de Previdência Social Português.

\subsubsection{Sujeitos da Previdência Social Portuguesa}

Com as mesmas características de literalidade e de objetividade que ostenta a legislação portuguesa, o Código dos Regimes Contributivos do Sistema Previdencial de Segurança Social (CCSS), já em seu artigo $1^{\circ}$, explicita seu âmbito de aplicação:

O presente Código regula os regimes abrangidos pelo sistema previdencial aplicáveis aos trabalhadores por conta de outrem ou em situação legalmente equiparada para efeitos de segurança social, aos trabalhadores independentes, bem como o regime de inscrição facultativa.

Destinado aos trabalhadores que entregam o esforço da prestação de seus serviços a outrem, o sistema previdencial, como se denomina o sistema previdenciário em Portugal, deve ser fundamentalmente autofinanciado, segundo o disposto no artigo $54^{\circ}$ da Lei de Bases, a mencionada Lei $\mathrm{n}^{\circ}$ 4, de 2007 , tendo por base uma relação sinalagmática direta entre a contribuição e o benefício previdenciário. ${ }^{135}$

Devemos realçar que a citada Lei de Bases, no artigo $23^{\circ}$, insere o sistema previdencial ao lado do sistema de proteção social de cidadania e do sistema complementar, no Sistema de Segurança Social de Portugal. O sistema previdencial tem por objetivos, segundo o artigo $63^{\circ}$ da Constituição Portuguesa, garantir, com base no princípio da solidariedade de base profissional, prestações pecuniárias substitutivas do rendimento do trabalho perdido em razão da ocorrência de eventualidades legalmente previstas.

Analisemos, com maior vagar, os sujeitos mencionados no artigo $1^{\circ}$ do CCSS. Iniciemos pelo trabalhador por conta de outrem.

\footnotetext{
${ }^{134}$ CABRAL, Nazaré da Costa. Contribuições para a Segurança Social: Natureza, Aspectos de Regime e de Técnica e Perspectivas de Evolução num Contexto de Incerteza. Coimbra: Almedina, 2010. p.10.

${ }^{135}$ CABRAL, Nazaré da Costa. Contribuições para a Segurança Social: Natureza, Aspectos de Regime e de Técnica e Perspectivas de Evolução num Contexto de Incerteza. Coimbra: Almedina, 2010. p. 31.
} 
Segundo o artigo $24^{\circ}$, inserido no Título I, que versa sobre o regime geral dos trabalhadores por conta de outrem, são abrangidos pelo regime geral, com caráter de obrigatoriedade, os trabalhadores que exercem atividade profissional remunerada ao abrigo de um contrato de trabalho, nos termos do disposto no Código de Trabalho. É dizer: trabalhador empregado. Ainda no artigo $24^{\circ}$, no $\mathrm{n}^{\mathrm{o}} 2$, consta a determinação de que algumas pessoas, em função das características específicas da atividade exercida, devem ser consideradas em situação equiparada à dos trabalhadores por conta de outrem nos termos constantes do CCSS. Seria esse o caso dos trabalhadores destacados, ${ }^{136}$ sem prejuízo do disposto em legislação própria e em instrumentos internacionais a que Portugal se encontre vinculado; dos trabalhadores que exercem a respectiva atividade em estabelecimentos de turismo rural, turismo de habitação e agroturismo; e ainda o dos trabalhadores que prestam serviço de limpeza em prédios em regime de propriedade horizontal.

Trabalhadores independentes, segundo o artigo $132^{\circ}$ do CSSS, são as pessoas singulares que exercem atividade profissional sem sujeição a contrato de trabalho ou a contrato legalmente equiparado, ou se obriguem a prestar a outrem o resultado da sua atividade. Exemplificando, o artigo $133^{\circ}$ em seu n ${ }^{\circ} 1$, menciona:

a) As pessoas que exerçam atividade profissional por conta própria geradora de rendimentos a que se reportam os artigos $3 .^{\circ}$ e $4 .^{\circ}$ do Código do Imposto sobre o Rendimento das Pessoas Singulares;

b) Os sócios ou membros das sociedades de profissionais definidas na alínea a) do.$^{\circ} 4$ do artigo $6 .^{\circ}$ do Código do Imposto sobre o Rendimento das Pessoas Coletivas;

c) Os cônjuges dos trabalhadores referidos na alínea a) que com eles exerçam efetiva atividade profissional com caráter de regularidade e de permanência;

d) Os sócios de sociedades de agricultura de grupo ainda que nelas exerçam atividade integrada nos respectivos órgãos estatutários;

e) Os titulares de direitos sobre explorações agrícolas ou equiparadas, ainda que a atividade nelas exercida se traduza apenas em atos de gestão, desde que tais atos sejam exercidos diretamente, de forma reiterada e com caráter de permanência.

Ainda exemplificando o conceito de trabalhador independente, o artigo $134^{\circ}$ do CCSS alude aos produtores agrícolas e aos seus cônjuges que tenham na agricultura sua atividade profissional. Menciona ainda os pescadores que efetivamente exerçam a

\footnotetext{
${ }^{136}$ Trabalhador destacado é aquele contratado por empregador estabelecido em outro Estado da UE, que presta sua atividade em Portugal (Art. $6^{\circ}$ do Código de Trabalho Português, CTP , aprovado pela Lei ${ }^{\circ}$ 7/2009), ou aquele que, contratado por empresa portuguesa, presta serviço em outro Estado (art. $9^{\circ}$, CTP).
} 
atividade profissional na pesca, mesmo que proprietários das embarcações, e os apanhadores de espécies marinhas e pescadores apeados.

As cooperativas de serviço e de produção podem optar, segundo o artigo $135^{\circ}$ e desde que constando em seus estatutos, sobre o enquadramento de seus membros trabalhadores pelo regime dos trabalhadores independentes; porém, manifestada essa opção, ela é inalterável por no mínimo cinco anos.

Os trabalhadores intelectuais, assim considerados os autores de obras protegidas pelo Código dos Direitos do Autor e dos Direitos Conexos, ${ }^{137}$ são considerados, segundo o artigo $136^{\circ}$, trabalhadores independentes.

Finalizando nossa análise do artigo $1^{\circ}$, devemos apontar a possibilidade da adesão facultativa ao Regime Geral Previdencial Português por todo aquele que não está obrigado a participar de outro regime previdenciário. ${ }^{138}$

O Capítulo II do diploma codificador português trata dos regimes aplicáveis a trabalhadores integrados em categorias ou situações específicas. São situações distintas dos meios usuais de prestação de serviços da pessoa física, como por exemplo, a relação subordinada por tempo indeterminado e o trabalho autônomo. Essas condições diferenciadas de contrato de trabalho, ou de tipo de trabalhador, podem ensejar situações previdenciárias distintas, segundo os preceitos do novo CCSS. A Seção I do Capítulo II versa sobre os trabalhadores com âmbito material de proteção reduzido. Nas subseções, em seus diversos artigos estão dispostos os âmbitos pessoais e materiais, base de cálculo e alíquotas de cada uma das categorias elencadas pelo legislador.

Iniciemos pelos membros dos órgãos estatutários das pessoas jurídicas e entidades equiparadas, mesmo que sejam sócios ou membros dessas pessoas. $\mathrm{O}$ artigo $62^{\circ}$, em rol taxativo, elucida:

a) Os administradores, diretores e gerentes das sociedades e das cooperativas;

b) Os administradores de pessoas coletivas gestoras ou administradoras de outras pessoas coletivas, quando contratados a título de mandato para aí exercerem funções de administração, desde que a responsabilidade pelo pagamento das respetivas remunerações seja assumida pela entidade administrada;

c) Os gestores de empresas públicas ou de outras pessoas coletivas, qualquer que seja o fim prosseguido, que não se encontrem obrigatoriamente abrangidos pelo regime de proteção social convergente

\footnotetext{
${ }^{137}$ Aprovado pelo Decreto Lei $\mathrm{n}^{\mathrm{o}}$ 63/85, com alterações posteriores.

${ }^{138}$ Cf. APELLES, J. B. Conceição. Segurança social - manual prático. 8. a ed. Coimbra: Almedina, 2008. p. 87.
} 
dos trabalhadores em funções públicas e que não tenham optado, nos termos legais, por diferente regime de proteção social de inscrição obrigatória;

d) Os membros dos órgãos internos de fiscalização das pessoas coletivas, qualquer que seja o fim prosseguido, que não se encontrem obrigatoriamente abrangidos pelo regime de proteção social convergente dos trabalhadores em funções públicas e que não tenham optado, nos termos legais, por diferente regime de proteção social de inscrição obrigatória;

e) Os membros dos demais órgãos estatutários das pessoas coletivas, qualquer que seja o fim prosseguido, que não se encontrem obrigatoriamente abrangidos pelo regime de proteção social convergente dos trabalhadores em funções públicas e que não tenham optado, nos termos legais, por diferente regime de proteção social de inscrição obrigatória.

Esclarecendo ainda mais, o artigo $63^{\circ}$ elenca quais membros não estão submetidos ao regime especial aplicável aos membros dos órgãos estatutários. São eles os membros de órgãos estatutários de pessoa jurídica sem fins lucrativos que não recebem remuneração; os sócios que não exercem a qualidade de gerentes, nem auferem remuneração; os sócios ou membros obrigatoriamente filiados a outros regimes de proteção social; os membros de órgãos estatutários das sociedades de agricultura de grupo; e os liquidatários judiciais.

O regime especial de proteção dos membros de órgãos estatutários, previstos no artigo $62^{\circ}$, possui característica especial, pois não protege contra o evento desemprego, segundo o disposto no artigo $65^{\circ}$, ambos do CCSS. Também têm o mesmo âmbito de cobertura do regime especial, segundo os preceitos dos artigos $71^{\circ}$ combinado com o $72^{\circ}$ do sistema normativo codificado, os trabalhadores que exercem suas atividades profissionais em sua própria residência. ${ }^{139}$

Os desportistas profissionais, assim entendidos aqueles que praticam modalidade desportiva como profissão principal sob contrato de trabalho desportivo, possuem, segundo os artigos $74^{\circ}$ e $75^{\circ}$ do CCSS, regime especial de proteção. Esse regime não cobre os eventos decorrentes de doenças comuns, mas protege contra desemprego, doenças profissionais, invalidez, velhice, morte e conta com apoio à parentalidade.

Os trabalhadores por contrato de muito curta duração ${ }^{140}$ também estarão sob a proteção de um regime especial e assegurados contra invalidez, morte e velhice, segundo o artigo $81^{\circ}{ }^{141}$

\footnotetext{
${ }^{139}$ Também não há cobertura contra o risco desemprego (artigo $72^{\circ} \mathrm{CCSS}$ ).

${ }^{140} \mathrm{O}$ contrato de trabalho de muito curta duração, previsto no artigo $142^{\circ}$ do Código de Trabalho Português, é cabível em atividades sazonais agrícolas e em evento turístico não superior a uma semana, e sua duração não pode exceder a 60 dias no ano civil.
} 
Os trabalhadores por conta de outrem com 55 anos ou mais que tenham firmado com seus empregadores acordos de pré-reforma, consoante a legislação laboral, ${ }^{142}$ mantêm o direito às proteções previstas no regime geral, porém, se o acordo previr a suspensão da prestação do trabalho, o trabalhador perde o direito à proteção contra doença, comum e profissional, apoio à parentalidade e seguro desemprego. ${ }^{143}$ Claro que se o trabalhador exercer outra atividade remunerada estará coberto pela situação. ${ }^{144}$

Os pensionistas de qualquer regime que, cumulativamente, exercerem atividade profissional têm direitos específicos, segundo o artigo $90^{\circ}$ do Código:

1 - Os pensionistas de invalidez têm direito à proteção nas eventualidades de parentalidade, doenças profissionais, invalidez, velhice e morte.

2 - Os pensionistas de velhice têm direito à proteção nas eventualidades de parentalidade, doenças profissionais, velhice e morte.

Martins adverte que os eventos que não foram estendidos pelo legislador aos pensionistas já se encontram cobertos pela situação de pensionista do segurado. ${ }^{145}$

O Código Contributivo continua ao longo do Capítulo II listando os trabalhadores que, por força de contrato de trabalho específico ou por condição distintiva na prestação de serviço por parte do trabalhador, fazem jus a distinções quanto à base de contribuição, alíquota ou benefícios. Isso ocorre com os trabalhadores em regime de trabalho intermitente (artigos $92^{\circ}$ a $94^{\circ}$ ), trabalhadores em atividades economicamente débeis (artigos $95^{\circ}$ e $96^{\circ}$ ), pescadores de pesca local e costeira (artigos $97^{\circ}$ a $99^{\circ}$ ), e trabalhadores domésticos (artigos $116^{\circ}$ ao $121^{\circ}$ ). As pessoas que exercem atividade profissional junto às Igrejas, associações e confissões religiosas têm seu trabalho equiparado ao trabalho do empregado, segundo Código Contributivo, e têm regime previdenciário contributivo segundo as disposições constantes dos artigos $122^{\circ}$ até $128^{\circ}$.

Examinados, ainda que perfunctoriamente, os sujeitos beneficiados pela segurança social oficial, observemos como o CCSS dispõe sobre os principais sujeitos responsáveis pelas contribuições previdenciárias, as empresas.

\footnotetext{
${ }^{141}$ Segundo Martins, pela ausência de proteção aos eventos doença (comum e profissional), parentalidade e desemprego, os trabalhadores sob contrato de muito curta duração só têm direito aos benefícios diferidos. Cf. MARTINS, Alcides. Legislação da Segurança Social. Lisboa: DisLivro, 2011. p. 65.

${ }^{142}$ O Código de Trabalho de Portugal, de 2011, regula em seus artigos $318^{\circ}$ a $322^{\circ}$ a pré-reforma, acordo pelo qual o trabalhador com 55 anos ou mais suspende ou reduz a prestação de trabalho. Durante esse período tem direito a receber do empregador uma prestação pecuniária mensal, também denominada pré-reforma.

${ }^{143}$ CCSS artigos $84^{\circ}$ até $88^{\circ}$.

${ }^{144}$ MARTINS, Alcides. Legislação da Segurança Social. Lisboa: DisLivro, 2011. p. 67.

${ }^{145}$ MARTINS, Alcides. ob. cit. p. 68.
} 
A primeira menção surge no artigo $6^{\circ}$, que trata sobre a vinculação, a denominação codicista para a relação jurídica representada pela ligação estabelecida entre as pessoas singulares ou coletivas e o sistema previdencial de segurança social. A vinculação ao sistema previdencial de segurança social efetiva-se através da inscrição na instituição de segurança social competente e tem por objeto a determinação dos titulares do direito à proteção social do sistema previdencial da segurança social, bem como dos sujeitos das obrigações.

A inscrição é o ato administrativo pelo qual se efetiva a vinculação ao sistema previdencial da segurança social e tem o condão de conferir a qualidade de beneficiário às pessoas singulares que preenchem as condições de enquadramento no âmbito pessoal de um dos regimes abrangidos pelo sistema previdencial. Confere, também, a qualidade de contribuinte às pessoas singulares ou coletivas que sejam entidades empregadoras, lembrando que a inscrição das entidades empregadoras é obrigatória, única e definitiva. ${ }^{146}$

Por fim, no tocante ao nosso interesse momentâneo, o artigo $10^{\circ}$ explicita a relação jurídica que se instaura entre a empresa e a segurança social:

1 - A relação jurídica contributiva consubstancia-se no vínculo de natureza obrigacional que liga ao sistema previdencial:

a) Os trabalhadores e as respetivas entidades empregadoras;

b) Os trabalhadores independentes e quando aplicável às pessoas coletivas e as pessoas singulares com atividade empresarial que com eles contratam;

c) Os beneficiários do regime de seguro social voluntário.

2 - A relação jurídica contributiva mantém-se mesmo nos casos em que normas especiais determinem a dispensa temporária, total ou parcial, ou a redução do pagamento de contribuições. (grifo nosso)

É necessário realçar a disposição da alínea ' $\mathrm{b}$ ' do $\mathrm{n}^{\mathrm{o}} 1$ do artigo $10^{\circ}$, que contém uma das mais significativas mudanças do novo código: a responsabilidade da empresa que contrata prestadores de serviço pelas contribuições referentes a essa contratação, e não somente pela contratação de empregados, como ocorria no passado. ${ }^{147}$

Vejamos, a partir de agora, os benefícios do regime geral previdencial português e sua forma de financiamento.

\subsubsection{Eventos cobertos pela Previdência Social e forma de financiamento}

\footnotetext{
${ }^{146}$ Artigo $8^{\circ}, \mathrm{n}^{\circ} 4$, do CCSS.

${ }^{147}$ Cf. MARTINS, Alcides. Legislação da Segurança Social. Lisboa: DisLivro, 2011. p. 26.
} 
Observamos, linhas atrás, que o Código Contributivo da Segurança Social, ao lado do regime geral, instituiu regimes especiais para algumas categorias específicas de trabalhadores, sobre os quais pudemos, mesmo que em rápidas pinceladas, refletir. Agora, vamos nos dedicar aos riscos assegurados pelo regime geral e quais as parcelas de participação no custeio cabíveis ao trabalhador e à empresa.

Preliminarmente, devemos apontar a ressalva - óbvia, porém norteadora do sistema previdenciário português - constante do artigo $18^{\circ}$, que expressamente preceitua serem condições gerais de acesso "à proteção social garantida pelos regimes do sistema previdencial a inscrição e o cumprimento da obrigação contributiva" pelos trabalhadores e, quando for o caso, pela empresa.

A relação jurídica prestacional previdenciária é designada, ao longo do código, por âmbito material, e apresenta para quais eventos futuros e incertos haverá cobertura por meio de prestação pecuniária, de serviços, ou de ambos, desde que existam os requisitos formais legalmente exigidos para a concessão e não prescindam da prévia contribuição.

A concertação social envolvida na elaboração do Código Contributivo resultou na eleição dos seguintes riscos protegidos: doença, maternidade, paternidade e adoção, ${ }^{148}$ desemprego, doenças profissionais, invalidez, velhice e morte. Tais contingências constavam do artigo 57 da Lei de Bases, Lei no 4/2007, não significando nesse aspecto nenhum avanço social, o que se pode compreender até pelo momento econômico vivido pelo país ibérico.

Transferindo nossa análise para o financiamento das prestações previdenciárias, que, como sabemos, é realizado pelas contribuições dos segurados e da empresa, observamos, de plano, que o CCSS denomina a contribuição do trabalhador como quotização e a parte patronal como contribuição. ${ }^{149}$ Importa realçar que cabe à empresa o desconto da quota devida pelos empregados e o recolhimento do valor retido juntamente com a contribuição patronal. ${ }^{150}$

Por coerência ao método adotado pelo legislador, que dividiu as disposições do Código da Segurança Social segundo o tipo de relação de trabalho mantida pelo segurado, as obrigações tributárias previdenciárias estão previstas em artigos distintos, estando as

\footnotetext{
${ }^{148}$ Os eventos maternidade, paternidade e adoção, ao longo do código, são denominados parentalidade (art. $\left.19, \mathrm{n}^{\circ} 4, \mathrm{CCSS}\right)$.

${ }^{149}$ Artigo 42, $\mathrm{n}^{\circ} 1$, CCSS.

${ }^{150}$ Artigo $42, \mathrm{n}^{\circ} 2$, CCSS.
} 
aplicáveis aos trabalhadores empregados dispostas nos artigos $37^{\circ}$ e seguintes, enquanto as previstas para os trabalhadores independentes se localizam a partir do artigo $150^{\circ}$ do CCSS. Ressalte-se ainda que as questões contributivas relacionadas às situações específicas se encontram dispostas em conjunto com as demais determinações destas situações.

Versando sobre o momento da ocorrência do fato gerador, o artigo $37^{\circ}$ preceitua que "a obrigação contributiva constitui-se com o início do exercício de atividade profissional pelos trabalhadores ao serviço das entidades empregadoras", e de imediato, em flagrante demonstração da importância do dever de informar, vem o artigo $38^{\circ}$, que explicita:

1 - A obrigação contributiva compreende a declaração dos tempos de trabalho, das remunerações devidas aos trabalhadores e o pagamento das contribuições e das quotizações.

2 - A obrigação contributiva vence-se no último dia de cada mês do calendário. (grifo nosso)

Tal disposição esclarece, de maneira pouco comum, que a obrigação contributiva é composta pela obrigação tributária principal - obrigação de pagar - e pela obrigação tributária acessória, obrigação de fazer, no sentido de prestar informações, entregar documentos, suportar a fiscalização etc. Inegável que a forma eleita pelo CCSS de explicitar a dupla face da obrigação tributária engrandece a obrigação acessória, que, como veremos, favorece o caráter social do tributo previdenciário, em face da vinculação com o benefício que ele financia.

A base de cálculo da contribuição da empresa e da quota do trabalhador é, segundo o artigo 44:

\footnotetext{
1 - Para a determinação do montante das contribuições das entidades empregadoras e das quotizações dos trabalhadores, considera-se base de incidência contributiva a remuneração ilíquida devida em função do exercício da atividade profissional ou decorrente da cessação do contrato de trabalho nos termos do presente Código. (grifo nosso)
}

Por remuneração ilíquida deve-se entender a remuneração total percebida pelo trabalhador ${ }^{151}$ em função do contrato de trabalho, ou seja, a contrapartida pelo serviço prestado. Corrobora o entendimento apresentado o artigo 46, quando, em seu n ${ }^{\circ} 1$, explicita

${ }^{151}$ Cf. MARTINS, Alcides. Legislação da Segurança Social. Lisboa: DisLivro, 2011. p. 44. 
que, para efeitos da delimitação da base de cálculo, consideram-se remunerações as prestações pecuniárias ou em espécie que, nos termos do contrato de trabalho, são devidas pelas entidades empregadoras aos trabalhadores como contrapartida do seu trabalho. $\mathrm{O} \mathrm{n}^{\circ}$ 2 , do mesmo artigo 46, determina, em lista exemplificativa, ${ }^{152}$ as verbas que integram a remuneração ${ }^{153}$ para efeitos tributários previdenciários. Vejamos, embora extensa:

2 - Integram a base de incidência contributiva, designadamente, as seguintes prestações:

a) A remuneração base, em dinheiro ou em espécie;

b) As diuturnidades e outros valores estabelecidos em função da antiguidade dos trabalhadores ao serviço da respetiva entidade empregadora;

c) As comissões, os bónus e outras prestações de natureza análoga;

d) Os prémios de rendimento, de produtividade, de assiduidade, de cobrança, de condução, de economia e outros de natureza análoga que tenham caráter de regularidade;

e) A remuneração pela prestação de trabalho suplementar;

f) A remuneração por trabalho noturno;

g) A remuneração correspondente ao período de férias a que o trabalhador tenha direito;

h) Os subsídios de Natal, de férias, de Páscoa e outros de natureza análoga;

i) Os subsídios por penosidade, perigo ou outras condições especiais de prestação de trabalho;

j) Os subsídios de compensação por isenção de horário de trabalho ou situações equiparadas;

1) Os valores dos subsídios de refeição, quer sejam atribuídos em dinheiro, quer em títulos de refeição;

m) Os subsídios de residência, de renda de casa e outros de natureza análoga, que tenham caráter de regularidade;

n) Os valores efetivamente devidos a título de despesas de representação desde que se encontrem pré-determinados e dos quais não tenham sido prestadas contas até ao termo do exercício;

o) As gratificações, pelo valor total atribuído, devidas por força do contrato ou das normas que o regem, ainda que a sua atribuição esteja condicionada aos bons serviços dos trabalhadores, bem como as que pela sua importância e caráter regular e permanente, devam, segundo os usos, considerar-se como elemento integrante da remuneração;

p) As importâncias atribuídas a título de ajudas de custo, abonos de viagem, despesas de transporte e outras equivalentes;

q) Os abonos para falhas;

r) Os montantes atribuídos aos trabalhadores a título de participação nos lucros da empresa, desde que ao trabalhador não esteja assegurada pelo contrato uma remuneração certa, variável ou mista adequada ao seu trabalho; (Nos termos dos artigos $4^{\circ}$ e $6^{\circ}$ da Lei n. $.^{\circ} 110 / 2009$, na redação dada pela Lei n. ${ }^{\circ}$ 55-A/2010, esta alínea carece de regulamentação, que

${ }^{152}$ Artigo 46, $\mathrm{n}^{\mathrm{o}} 5$, do CCSS.

153 As verbas constantes das alíneas negritadas têm nítido caráter indenizatório e, assim consideradas, contrariam a disposição do caput do artigo 46, que explicita serem base de cálculo as verbas salariais, assim entendidas aquelas recebidas como contrapartida do trabalho. Cf. MARTINS, Alcides. ob. cit. p. 47. 
será precedida de avaliação efetuada em Concertação Social e não ocorre antes de 1 de janeiro de 2014).

s) As despesas resultantes da utilização pessoal pelo trabalhador de viatura automóvel que gere encargos para a entidade empregadora nos termos do artigo seguinte;

t) As despesas de transporte, pecuniárias ou não, suportadas pela entidade empregadora para custear as deslocações em benefício dos trabalhadores, na medida em que estas não se traduzam na utilização de meio de transporte disponibilizado pela entidade empregadora ou em que excedam o valor de passe social ou, na inexistência deste, o que resultaria da utilização de transportes coletivos, desde que quer a disponibilização daquele quer a atribuição destas tenha caráter geral;

u) Os valores correspondentes às retribuições a cujo recebimento os trabalhadores não tenham direito em consequência de sanção disciplinar;

v) Compensação por cessação do contrato de trabalho por acordo apenas nas situações com direito a prestações de desemprego;

$\mathrm{x})$ Os valores despendidos obrigatória ou facultativamente pela entidade empregadora com aplicações financeiras, a favor dos trabalhadores, designadamente seguros do ramo «Vida», fundos de pensões e planos de poupança, reforma ou quaisquer regimes complementares de segurança social, quando sejam objeto de resgate, adiantamento, remição ou qualquer outra forma de antecipação de correspondente disponibilidade ou em qualquer caso de recebimento de capital antes da data da passagem à situação de pensionista, ou fora dos condicionalismos legalmente definidos; (Nos termos dos artigos $4^{\circ}$ e $6^{\circ}$ da Lei n. ${ }^{\circ} 110 / 2009$, na redação dada pela Lei n. ${ }^{\circ}$ 55-A/2010, esta alínea carece de regulamentação, que será precedida de avaliação efetuada em Concertação Social e não ocorre antes de 1 de janeiro de 2014)

z) As importâncias auferidas pela utilização de automóvel próprio em serviço da entidade empregadora;

aa) As prestações relacionadas com o desempenho obtido pela empresa quando, quer no respetivo título atributivo quer pela sua atribuição regular e permanente, revistam caráter estável independentemente da variabilidade do seu montante. (Nos termos dos artigos $4^{\circ}$ e $6^{\circ}$ da Lei n..$^{\circ}$ 110/2009, na redação dada pela Lei n. ${ }^{\circ}$ 55-A/2010, esta alínea carece de regulamentação, que será precedida de avaliação efetuada em Concertação Social e não ocorre antes de 1 de janeiro de 2014).

(grifos nossos)

A longa transcrição se justifica pela minúcia que permeou o trabalho do legislador, preocupado em especificar, sem deixar margens interpretativas, as verbas integrantes da base contributiva.

As alíquotas aplicáveis estão dispostas nos artigos 49 e seguintes e são denominadas taxa contributiva. A taxa contributiva do regime geral é determinada, de forma global, em harmonia com o seu âmbito material. A taxa contributiva global integra o custo correspondente a cada uma das eventualidades protegidas pelo Sistema Previdencial, elencadas no mencionado artigo $28^{\circ}$ do CCSS. O custo é calculado em função do valor de cada uma das seguintes parcelas: a) Custo técnico das prestações; b) Encargos de 
administração; c) Encargos de solidariedade laboral; d) Encargos com políticas ativas de emprego e valorização profissional. Tal discriminação permite revisões a cada cinco anos, em função de variações ocorridas e adequação ao cálculo atuarial. ${ }^{154}$

A taxa contributiva global do regime geral correspondente ao elenco das eventualidades protegidas é de $34,75 \%$, cabendo $23,75 \%$ à entidade empregadora e $11 \%$ ao trabalhador, em regra.

Passando nossa análise para o trabalhador independente, vemos que ele tem sua obrigação tributária definida no artigo $150^{\circ}$ do Código, que, no $\mathrm{n}^{\circ} 2$, já faz a necessária distinção entre o independente que trabalha para empresa, ou equiparado, e o independente puro, que trabalha por sua conta e risco, igualando-o às entidades empregadoras.

A base contributiva do trabalhador independente considera seu rendimento relevante, determinado, segundo o artigo $162^{\circ}$, nos seguintes termos: i) $70 \%$ do valor total de prestação de serviços no ano civil imediatamente anterior ao momento de fixação da base de incidência contributiva; ii) 20\% dos rendimentos associados à produção e venda de bens no ano civil imediatamente anterior ao momento de fixação da base de incidência contributiva. Os trabalhadores independentes que desenvolvam serviços prestados no âmbito de atividades hoteleiras e similares, restauração e bebidas, e que o declarem fiscalmente como tal, têm a determinação do rendimento relevante feita por aplicação do coeficiente de $20 \%$. Se o trabalhador independente for abrangido pelo regime de contabilidade organizada, previsto no Código do Imposto sobre o Rendimento das Pessoas Singulares, seu rendimento relevante será o corresponde ao valor do lucro tributável sempre que esse seja de valor inferior ao que resulta dos critérios anteriormente mencionados.

Constitui base de incidência contributiva do trabalhador autônomo o "escalão de remuneração", determinado por referência ao duodécimo do rendimento relevante. Ao duodécimo do rendimento relevante, convertido em percentagem do Indexante de Apoios Sociais (IAS), corresponde o escalão de remuneração convencional, cujo valor seja imediatamente inferior. A base de incidência da empresa é o valor do serviço prestado.

A taxa contributiva, a alíquota, a cargo dos trabalhadores independentes, em regra, é de 29,6\%. Já a alíquota dos produtores agrícolas e respectivos cônjuges é de 28,3\%. Por seu turno, a alíquota das entidades contratantes dos serviços prestados por autônomos é de $5 \%$.

${ }^{154}$ Artigo 51, no 2, do CCSS. 


\subsubsection{Tutelas}

Pudemos observar, linhas atrás, que o Código dos Regimes Contributivos da Segurança Social, ao definir obrigação contributiva, inseriu no próprio conceito a declaração dos tempos de trabalho e das remunerações devidas aos trabalhadores, explicitando o caráter obrigacional do dever de prestar informações. Explicitou este dever no artigo $40^{\circ}$, que, em seu $n^{\circ} 1$, determina:

1 - As entidades contribuintes são obrigadas a declarar à segurança social, em relação a cada um dos trabalhadores ao seu serviço, o valor da remuneração que constitui a base de incidência contributiva, os tempos de trabalho que lhe corresponde e a taxa contributiva aplicável. (grifo nosso)

O artigo $41^{\circ}$ do CCSS determina que a declaração prevista no artigo $40^{\circ}$ deve ser entregue por meio de transmissão eletrônica de dados, diretamente no sítio da Segurança Social Portuguesa. Ainda segundo o mencionado artigo $41^{\circ}$, as entidades contribuintes que sejam pessoas singulares e que tenham a seu serviço apenas um trabalhador, poderão entregar a declaração em meio papel. Porém, se o fizerem pelo meio eletrônico, a opção se torna irrevogável.

Somente pelo exposto, já se pode - com nitidez - observar a intenção do legislador na tutela eficaz das informações que embasam a quotização pelo trabalhador e contribuição da empresa. Claro que o interesse fiscal também fundamenta a proteção mencionada, todavia, não nos esqueçamos de que em Portugal, como nos outros ordenamentos previdenciários que estudamos, a concessão dos benefícios se baseia nos valores da contribuição. ${ }^{155}$

Importante, nesse ponto, realçar que, segundo o disposto no artigo 29, é obrigação do empregador a comunicação da admissão de trabalhador, sendo contraordenação sua omissão. No mesmo sentido da ciência dos fatos geradores de suas obrigações e direitos da Segurança Social, o empregador é obrigado a comunicar, por meio da internet, a cessação, suspensão e alteração do contrato de trabalho, consoante as regras do artigo 32, que também considera contraordenação o eventual descumprimento.

${ }^{155}$ Ver item 3.3.2 do presente capítulo. 
No sentido do incentivo à regularidade fiscal, o artigo $59^{\circ}$ do CCSS determina que a concessão de isenção ou redução da contribuição ou, ainda, a manutenção desses benefícios depende da verificação da regularidade do contribuinte perante a Segurança Social. Outras medidas estabelecem sanções, como punições ou premiações, para coagir ao cumprimento da obrigação de informar.

Como exemplo das medidas sancionadoras punitivas, sanção clássica, temos a imputação de contraordenações, ${ }^{156,157}$ graduadas em leves, médias, graves e muito graves, as quais, segundo o artigo $232^{\circ}$ e seguintes do CCSS, são punidas com multas, variáveis entre $€ 50$ e 250 e passíveis de agravamento. A reincidência de práticas em contraordenação grave ou muito grave, segundo o artigo $238^{\circ}$ do código, é punível, com sanção acessória de privação do acesso a medidas de estímulo à criação de postos de trabalho e à reinserção profissional. Importante registrar que o CCSS tipifica a negligência. De acordo com o artigo $228^{\circ}{ }^{158}$ nas condutas de inconformidade, consideradas contraordenações, a negligência é sempre punível. Coexistem com as contraordenações as sanções pecuniárias, multas moratórias, aplicáveis no descumprimento da obrigação principal.

Relevante é a utilização de sanções premiais pelo código de segurança social. Além da determinação, vista acima, que condiciona o contribuinte a manter regularidade fiscal para que possa obter benefícios, inclusive com divulgação de lista de inadimplentes, ${ }^{159}$ a legislação codificada institui outras vantagens para os contribuintes que cumprem espontaneamente, mesmo que com algum atraso, suas obrigações.

Exemplificamos por meio do artigo $241^{\circ}$, que versa sobre as situações atenuantes das multas. Vejamos a dicção de seu ${ }^{\circ} 1$ :

1 - Sempre que as obrigações previstas nos $n .^{\circ} 1$ e 2 do artigo $29 .^{\circ}, n^{\circ} 1$ do artigo $32 .^{\circ}$, n. ${ }^{\circ} 1$ e 2 do artigo $36^{\circ}$, n. $^{\circ} 1$ do artigo $40 .^{\circ}$, n. $^{\circ} 1$ do artigo $149 .^{\circ}$ e.$^{\circ} 1$ do artigo $153 .^{\circ}$ sejam cumpridas dentro dos primeiros 30 dias seguintes ao último dia do prazo, os limites máximos das coimas

\footnotetext{
156 Artigo $221^{\circ}$ do CCSS: "Constitui contraordenação para efeitos do presente Código todo o facto ilícito e censurável, nele previsto e na legislação que o regulamenta, que preencha um tipo legal para o qual se comine uma coima."

${ }^{157}$ O CCSS prevê contraordenações como sanção pelo descumprimento de dever nos artigos: 29, $n^{\circ} 7$, que trata da comunicação de admissão; $32, n^{\circ} 4$, que versa sobre a comunicação das cessações, alterações e suspensões do contrato de trabalho; 36, n. $^{\circ} 4$ e 5 , que dispõe sobre o dever da entidade empregadora de comunicar sobre alterações de sua identificação; 40, $\mathrm{n}^{\circ} 6$, que trata do dever de informação sobre os dados dos trabalhadores; e 42, $\mathrm{n}^{\circ} 3$, que trata do dever de reter e recolher as contribuições e quotizações.

${ }^{158}$ Art. 228: "Nas contraordenações previstas no presente Código a negligência é sempre punível."

${ }^{159} \mathrm{O}$ artigo 214 do CCSS regulamenta a divulgação das listas de contribuintes com situação irregular, assim entendidos aqueles que não regularizaram seus débitos e não prestaram garantias no prazo estipulado.
} 
aplicáveis não podem exceder em mais de $75 \%$ o limite mínimo previsto para o tipo de contraordenação praticada. (grifo nosso)

Infere-se do exposto a intenção do legislador em obter a informação desejada, mesmo que extemporaneamente. Trata-se da típica proteção que leva em consideração a natureza do ditame legal, ou seja, a finalidade, o objetivo que o legislador teve ao introduzir aquela conduta, aquela obrigação, no texto normativo. Observemos que todos os artigos mencionados se referem ao dever de prestar informações, de municiar o órgão previdenciário de dados dos trabalhadores.

Nesse mesmo sentido, as disposições do artigo $244^{\text {o160 }}$ determinam a dispensa da multa nos casos de arrependimento eficaz do contribuinte, ou seja, quando o contribuinte negligente, que, por inércia, deixou de cumprir sua obrigação, regulariza a falta cometida e, assim, não causa prejuízo ao sistema de segurança social e nem ao trabalhador.

Não obstante o exposto, o exemplo máximo de tutela eficaz encontra-se na determinação do artigo 40, n⿳3 3, que imputa à Administração Pública que supra de ofício a falha nas informações prestadas, mesmo considerando essa falha uma contraordenação, punível por sanção, com a aplicação de uma coima. Além disso, ainda há, por parte do legislador, o estímulo ao adimplemento da obrigação, mesmo que intempestivo, com a sanção premial da diminuição da multa se houver o cumprimento do dever. Tudo no intento de se proteger as informações que interessam ao trabalhador e, simultaneamente, ao Fisco.

Observemos a transcrição integral do artigo $40^{\circ}$, que fazemos pelo brilhantismo do conteúdo e clareza de redação:

1 - As entidades contribuintes são obrigadas a declarar à segurança social, em relação a cada um dos trabalhadores ao seu serviço, o valor da remuneração que constitui a base de incidência contributiva, os tempos de trabalho que lhe corresponde e a taxa contributiva aplicável.

2 - A declaração prevista no número anterior deve ser efetuada até ao dia 10 do mês seguinte àquele a que diga respeito.

3 - Sem prejuízo do disposto no número seguinte, a falta ou a insuficiência das declarações previstas nos números anteriores podem ser supridas oficiosamente pela instituição de segurança social competente designadamente por recurso aos dados de que disponha

160 Art. 241, CCSS: "Nos casos de contraordenação leve pode a instituição de segurança social competente dispensar a aplicação de coima, desde que se verifiquem cumulativamente as seguintes circunstâncias:

a) A prática da infração não ocasione prejuízo efetivo ao sistema de segurança social nem ao trabalhador;

b) Esteja regularizada a falta cometida;

c) A infração tenha sido praticada por negligência." 
no seu sistema de informação, no sistema de informação fiscal ou decorrente de ação de fiscalização.

4 - O suprimento oficioso das declarações previstas nos números anteriores é notificado à entidade contribuinte nos termos do disposto no Código do Procedimento Administrativo.

5 - A não inclusão de trabalhador na declaração de remunerações constitui contraordenação muito grave.

6 - Sem prejuízo do disposto no número anterior, a violação do disposto nos $n .^{\circ} 1$ e 2 constitui contraordenação leve quando seja cumprida nos 30 dias subsequentes ao termo do prazo e constitui contraordenação grave nas demais situações. (grifo nosso) 


\section{CAPÍTULO 4 - ASPECTOS RELEVANTES DA GFIP - GUIA DE RECOLHIMENTO DO FGTS E INFORMAÇÕES À PREVIDÊNCIA SOCIAL}

\subsection{Surgimento da GFIP}

Em 10 de dezembro de 1997, foi publicada a Lei $\mathrm{n}^{\circ} 9.528$ que, por meio do disposto em seu artigo $1^{\circ}$, introduziu o inciso IV e seus 11 parágrafos, ao artigo 32 da Lei n 8.212, de 1999, denominada Lei de Custeio da Previdência Social. Vejamos:

Art. 32. A empresa também é obrigada a:

$\cdots$

IV - informar mensalmente ao Instituto Nacional do Seguro Social - INSS, por intermédio de documento a ser definido em regulamento, dados relacionados aos fatos geradores de contribuição previdenciária e outras informações de interesse do INSS.

$\S 1^{\circ} \mathrm{O}$ Poder Executivo poderá estabelecer critérios diferenciados de periodicidade, de formalização ou de dispensa de apresentação do documento a que se refere o inciso IV, para segmentos de empresas ou situações específicas.

$\S 2^{\circ}$ As informações constantes do documento de que trata o inciso IV, servirão como base de cálculo das contribuições devidas ao Instituto Nacional do Seguro Social - INSS, bem como comporão a base de dados para fins de cálculo e concessão dos benefícios previdenciários.

$\S 3^{\circ} \mathrm{O}$ regulamento disporá sobre local, data e forma de entrega do documento previsto no inciso IV.

$\S 4^{\circ}$ A não apresentação do documento previsto no inciso IV, independentemente do recolhimento da contribuição, sujeitará o infrator à pena administrativa correspondente a multa variável equivalente a um multiplicador sobre o valor mínimo previsto no art. 92, em função do número de segurados, conforme quadro abaixo:

\begin{tabular}{|l|r|}
\hline 0 a 5 segurados & $1 / 2$ valor mínimo \\
\hline 6 a 15 segurados & $1 \times$ o valor mínimo \\
\hline 16 a 50 segurados & $2 \times$ o valor mínimo \\
\hline 51 a 100 segurados & $5 \times$ o valor mínimo \\
\hline 101 a 500 segurados & 10 x o valor mínimo \\
\hline 501 a 1000 segurados & 20 x o valor mínimo \\
\hline 1001 a 5000 segurados & 35 x o valor mínimo \\
\hline acima de 5000 segurados & 50 x o valor mínimo \\
\hline
\end{tabular}

$\S 5^{\circ} \mathrm{A}$ apresentação do documento com dados não correspondentes aos fatos geradores sujeitará o infrator à pena administrativa correspondente à multa de cem por cento do valor devido relativo à contribuição não declarada, limitada aos valores previstos no parágrafo anterior. 
$\S 6^{\circ}$ A apresentação do documento com erro de preenchimento nos dados não relacionados aos fatos geradores sujeitará o infrator à pena administrativa de cinco por cento do valor mínimo previsto no art. 92, por campo com informações inexatas, incompletas ou omissas, limitadas aos valores previstos no $\S 4^{\circ}$.

$\S 7^{\circ}$ A multa de que trata o $\S 4^{\circ}$ sofrerá acréscimo de cinco por cento por mês calendário ou fração, a partir do mês seguinte àquele em que o documento deveria ter sido entregue.

$\S 8^{\circ} \mathrm{O}$ valor mínimo a que se refere o $\S 4^{\circ}$ será o vigente na data da lavratura do auto de infração.

$\S 9^{\circ} \mathrm{A}$ empresa deverá apresentar o documento a que se refere o inciso IV, mesmo quando não ocorrerem fatos geradores de contribuição previdenciária, sob pena da multa prevista no $\S 4^{\circ}$.

$\S 10$. O descumprimento do disposto no inciso IV é condição impeditiva para expedição da prova de inexistência de débito para com o Instituto Nacional do Seguro Social - INSS.

$\S 11$. Os documentos comprobatórios do cumprimento das obrigações de que trata este artigo devem ficar arquivados na empresa durante dez anos, à disposição da físcalização. (grifos nossos)

Assim, com o advento da Lei $n^{\circ}$ 9.528, de 1997, a Lei de Custeio da Previdência Social passou, ${ }^{161}$ dentre as obrigações que impõe às empresas, ${ }^{162}$ a imputar o dever de informação.

A mencionada Lei $\mathrm{n}^{\circ}$ 9.528, de 1997 não denominou o documento que criava, delegando ao regulamento essa missão. Tal regulamentação se deu por meio do Decreto $\mathrm{n}^{\circ}$ 2.803, de 20 de outubro de 1998, revogado em maio de 1999 pelo Decreto ${ }^{\circ} 3.048$, que aprovou o vigente Regulamento da Previdência Social. O artigo $1^{\circ}$ do efêmero Decreto ${ }^{\circ}$ 2.803 denominou o documento de Guia de Informações à Previdência Social e de Recolhimento de FGTS (GFIP), como até hoje é conhecido.

O legislador, ao estabelecer o conjunto de dados que deveriam ser apresentadas na guia, determinou que constariam informações de todos os fatos geradores de contribuição previdenciária e outras de interesse do Instituto Nacional do Seguro Social (INSS). Para não deixar nenhuma dúvida de sua intenção, esclareceu, no parágrafo $2^{\circ}$ do inciso $\mathrm{V}$ do artigo acima transcrito, a que se destinavam essas informações de interesse da Autarquia Previdenciária: a servir como base de cálculo das contribuições devidas ao INSS, bem como a comporem a base de dados para fins de cálculo e concessão dos benefícios previdenciários.

Ao mesmo tempo, buscando uma sinergia de difícil concretização, a GFIP se prestava a ser a guia de recolhimento do FGTS, ou seja, de um lado documento tributário,

${ }^{161}$ Sobre deveres de informação antes da GFIP, ver item 5.1 do Capítulo 5.

${ }^{162}$ A esse tipo de obrigação imposta por lei tributária, típica obrigação de fazer, com objetivo de permitir à Administração Tributária a fiscalização ou arrecadação de tributos, denomina-se obrigação acessória, consoante o artigo 113, $\S 2^{\circ}$ do Código Tributário Nacional, CTN. 
obrigação acessória típica, do qual constavam informações sobre todos os fatores geradores de contribuições previdenciárias, além de informações para a concessão de benefícios previdenciários; e de outro, guia de recolhimento do FGTS, o que permite pressupor que a guia deveria conter os dados necessários para que calcule o valor desse recolhimento.

Para que a complexa missão fosse levada a cabo, criou-se de um grupo de trabalho composto pela DATAPREV, a empresa de processamento de dados da Previdência Social; pela Caixa Econômica Federal, agente operador do FGTS; e pelo INSS, Instituto Nacional do Seguro Social.

Em 19 de outubro de 1988, a Caixa emitiu a Circular $n^{\circ} 151$, que introduziu modificações e formulários pertinentes aos recolhimentos dos depósitos do FGTS, da multa rescisória, do depósito do FGTS do mês da rescisão e de mês imediatamente anterior; alterou procedimentos relativos à operacionalização do FGTS e definiu procedimentos atinentes à prestação de informações à Previdência Social. Estava, então, normatizada a GFIP.

Em seus 23 itens, a Circular $n^{\circ} 151$ especificava o documento e fornecia as primeiras orientações sobre seu preenchimento, apesar de remeter ao Manual ${ }^{163}$ da GFIP, ${ }^{164}$ criação do MPAS, da Caixa e do INSS. Também determinava a vigência, logo em seu item 1.1, que explicitava:

\footnotetext{
A partir de 01 FEV 1999 os recolhimentos do FGTS, para todas as modalidades de depósitos, à exceção dos valores inscritos em dívida ativa, deverão ser efetuados através da Guia de Recolhimento do Fundo de Garantia do Tempo de Serviço e Informações à Previdência Social - GFIP, da Guia de Recolhimento Rescisório do FGTS e informações à Previdência Social - GRFP ou do Documento Específico de Recolhimento do FGTS - DERF, em substituição aos atuais formulários Guia de Recolhimento do FGTS - GRE e Guia de Recolhimento Rescisório do FGTS - GRR. (grifo nosso)
}

Implantada de forma gradativa, ${ }^{165}$ a entrega da GFIP tem alto grau de adesão por parte das empresas, e isso se deve mais ao fato de ser o meio de recolhimento do FGTS do que à compulsoriedade legalmente imposta.

Como explicitado, a partir de fevereiro de 1999, a Previdência Social e a Caixa, o agente operador do FGTS, passaram a receber as informações dos trabalhadores, fornecidas pelo próprio empregador, e relacionadas aos benefícios legais administrados por

\footnotetext{
${ }^{164}$ O Manual da GFIP atualmente em vigor, aprovado pela Instrução Normativa RFB n 880 , de 2008, pode ser consultado em: http://www.receita.fazenda.gov.br/previdencia/gfip/gfip3manform.htm

${ }^{165}$ Circular CAIXA n ${ }^{\circ} 151$, item 1.2.
} 
cada um dos órgãos. Com isso, o ganho de gestão e a facilidade de operacionalização dos benefícios devidos, os quais decorrem do conhecimento dos recolhimentos e da remuneração de cada trabalhador, conteúdo mínimo contido em cada GFIP, são evidentes. Para melhor dimensioná-los, veremos, a seguir, quais dados identificadores dos trabalhadores e do contratante compõem a guia de informações. Em seguida, observaremos, com maior detalhamento, os elementos financeiros representativos das prestações de serviço declaradas em GFIP.

\subsection{O empregador na GFIP}

Devemos, antes de tudo, ressaltar que todo trabalhador que labora para empresa ou a ela equiparada deve constar na GFIP do tomador de serviços. ${ }^{166}$ Ou seja, a GFIP não se destina somente ao empregado, mas também às demais pessoas físicas que trabalham mediante remuneração, pois todas são seguradas obrigatórias da Previdência Social.

Se os dados apresentados não se relacionarem ao vínculo de emprego ou mesmo emprego doméstico não serão úteis ao FGTS, o que não desobriga a empresa, ou o a ela equiparado, a prestar as informações. ${ }^{167}$ Assim, devem recolher e informar a GFIP as pessoas físicas ou jurídicas e os contribuintes equiparados à empresa sujeitos ao recolhimento do FGTS, conforme estabelece a Lei $\mathrm{n}^{\circ}$ 8.036, de 11/05/1990, com as alterações posteriores, bem como aquelas pessoas sujeitas à prestação de informações à Previdência Social, conforme disposto na Lei nº 8.212, de 24/07/1991. Ressalvamos que é facultado ao empregador doméstico recolher FGTS para o seu empregado. No entanto, ao decidir fazê-lo, não poderá interromper o recolhimento, salvo se houver rescisão contratual.

Claro está que a Guia de Informações se presta a povoar o banco de dados da Previdência Social com os dados do trabalhador, a fornecer a base de cálculo das contribuições previdenciárias incidentes sobre a folha de pagamento das empresas, e a informar a base de cálculo do FGTS, no caso de segurados empregados. Desse modo, os dados relativos ao obrigado ao preenchimento e envio da GFIP, ou seja, os dados da

\footnotetext{
166 Utilizaremos a expressão tomador de serviços no sentido daquele que se utiliza da mão-de-obra remunerada da pessoa física, independentemente da relação de trabalho que se mantenha entre o tomador e o prestador de serviço. Nesse ponto, a expressão em italiano “dattore di lavoro” é muito mais útil que a nossa expressão empregador, muito mais afeita à relação de emprego do que ao gênero, relação de trabalho.

${ }^{167}$ Manual da GFIP, aprovado pela Instrução Normativa RFB n ${ }^{\circ} 80$, de 2008, item 2.
} 
empresa, são os dados que permitem a correta identificação dessa, já que a GFIP ostenta caráter de confissão de dívida tributária. ${ }^{168}$

Portanto, a empresa, ou o a ela equiparado, deve informar seus dados cadastrais, assim entendidos, a inscrição (CNPJ ou CEI), a razão ou denominação social se pessoa jurídica, ou nome, se pessoa física; além do telefone, e-mail, o logradouro completo do detentor do certificado, responsável pela transmissão da GFIP pelo Conectividade Social, ${ }^{169}$ bem como o nome da pessoa para contato.

É necessário ainda informar os dados relativos ao movimento financeiro, quais sejam: remuneração dos trabalhadores, inclusive as remunerações decorrentes de acordo coletivo, convenção coletiva, dissídio coletivo, reclamatória trabalhista e Comissões de Conciliação Prévia; comercialização da produção; receita de eventos desportivos/patrocínio; compensação; retenção sobre nota fiscal/fatura (Lei n 9.711/98); recolhimento de competências anteriores; deduções; pagamento a cooperativas de trabalho etc.

Também deve ser inserida na Guia de Informação a classificação CNAE $^{170}$ da empresa, segundo a tabela de códigos CNAE 2.0, uma vez que tal informação é fundamental para a obtenção da alíquota SAT pela qual a empresa deverá contribuir para o financiamento do seguro acidente do trabalho.

Com o fito de se determinar o valor a ser recolhido pelo tomador de serviços aos terceiros, assim denominada a contribuição social destinada ao financiamento do chamado Sistema S (SESI, SENAI, SENAC, SEBRAE etc.), a empresa deve informar seu código FPAS (Fundo da Previdência e Assistência Social), também ligado à sua atividade econômica, que, além de definir as entidades beneficiadas com sua contribuição, determinará a alíquota aplicável, incidente sobre a remuneração paga aos seus segurados empregados.

\subsection{O Trabalhador na GFIP}

\footnotetext{
${ }^{168}$ Esmiuçaremos essa característica da GFIP no Capítulo 5, itens 5.1 e 5.4.

${ }^{169}$ A GFIP é enviada eletronicamente por um sistema denominado Conectividade Social, de responsabilidade de um eleito pela empresa, que se identifica por meio de um certificado digital.

${ }^{170}$ Classificação Nacional da Atividade Econômica segundo o sitio da Receita Federal do Brasil é o instrumento de padronização nacional dos códigos de atividade econômica e dos critérios de enquadramento utilizados pelos diversos órgãos da Administração Tributária do país, e é aplicada a todos os agentes econômicos que estão engajados na produção de bens e serviços, podendo compreender estabelecimentos de empresas privadas ou públicas, estabelecimentos agrícolas, organismos públicos e privados, instituições sem fins lucrativos e agentes autônomos (pessoa física). (Disponível em: http://www.receita.fazenda.gov.br/pessoajuridica/cnaefiscal/txtcnae.htm. Acesso em: 22 out. 2012.)
} 
Por óbvio, os dados cadastrais dos trabalhadores também devem ser informados. Além do nome, data de nascimento e endereço completos, são necessários o número de inscrição no PIS/PASEP, no caso de segurados empregados, trabalhadores avulsos, domésticos e contribuintes individuais. Substitui o número do PIS/PASEP, no caso do contribuinte individual, a inscrição desse na Previdência Social, que pode ser realizada por meio do sítio do INSS ou pela Central de Atendimento, o chamado telefone 135. Necessário também informar o código do trabalhador, ${ }^{171}$ que é relacionado à sua categoria, assim entendido o vínculo, o tipo de relação de trabalho que existe entre a empresa e a pessoa física, além da data de início desse vínculo.

Finalmente, compõe as informações cadastrais o número CBO (Classificação Brasileira de Ocupações), que codifica a atividade desenvolvida, permitindo um maior conhecimento do mercado de trabalho e o aprimoramento de políticas públicas direcionadas a esse mercado e ao trabalhador. Os segurados empregados terão o número de sua Carteira de Trabalho e Previdência Social (CTPS) informados na GFIP.

Somente da análise dos dados cadastrais já podemos começar a observar a importância da Guia de Informações para o trabalhador. Nela consta o vínculo, o tipo de relação de trabalho que o une ao tomador de serviços, e mais o faz contemporaneamente ao desenvolvimento da relação, sendo, por vezes, importantíssimo documento de prova, ${ }^{172}$ dado seu caráter declaratório. Assim, independentemente da relação trabalhista existente, o trabalhador terá seus direitos previdenciários implementados mensalmente, graças à notícia que a Autarquia Previdenciária tem do desenvolvimento dessa relação. Passemos, agora, ao exame dos campos específicos.

Como é assente, cabe à Previdência Social suprir a renda do trabalhador nos casos de impossibilidade deste, temporária ou permanentemente, de prestar serviços. Na maioria das vezes, essa decorre da perda da saúde, e esta enfermidade pode ser causada pelas próprias condições em que ocorre o trabalho, isto porque a prestação pessoal dos serviços se dá, algumas vezes, na presença de agentes nocivos presentes no meio ambiente do trabalho, sejam eles físicos, químicos ou biológicos. ${ }^{173}$

Salta aos olhos a necessidade da Autarquia Previdenciária de conhecer os trabalhadores expostos às condições de trabalho insalubres, causadoras de inúmeras

\footnotetext{
${ }^{171}$ Ver Anexo I.

${ }^{172}$ Inúmeros julgados da Justiça do Trabalho se fundam nas informações prestadas em GFIP.

${ }^{173}$ As consequências tributárias previdenciárias de tal exposição estão expostas na Lei n 8.213/91, art. 57, § $6^{\circ}$.
} 
doenças profissionais e ensejadoras de aposentadoria especial, consoante o disposto no artigo 57 da Lei de Benefícios. Assim, se motiva a previsão da informação em GFIP, no campo Ocorrências, da exposição ou não do trabalhador, de modo permanente, a agentes nocivos à sua saúde ou à sua integridade física, e que demandem a concessão de aposentadoria especial. Informa-se também, no mesmo campo, se o trabalhador tem um ou mais vínculos empregatícios ou fontes pagadoras, ou, ainda, se o trabalhador está em mais de uma GFIP/SEFIP do mesmo empregador ou contribuinte. ${ }^{174}$

Importante explicar que, para classificação da ocorrência, deve ser consultada a tabela de Classificação dos Agentes Nocivos (Anexo IV do Regulamento da Previdência Social, aprovado pelo Decreto $n^{\circ} 3.048 / 99$ e alterações posteriores). Para a comprovação de que o trabalhador está exposto aos agentes nocivos é necessário que a empresa mantenha Perfil Profissiográfico Previdenciário (PPP), ${ }^{175}$ conforme disposto no art. 58, $\S 1^{\circ}$, da Lei $n^{\circ} 8.213 / 91$.

Por fim, no tocante ao campo ocorrências, e demonstrando que a GFIP se presta a resguardar os interesses de todos os trabalhadores e não somente dos empregados, apontemos que os códigos de ocorrência indicativos de exposição a agentes nocivos devem ser informados para o cooperado filiado à cooperativa de produção que exerce atividade que permita a concessão de aposentadoria especial, ficando o cálculo da contribuição adicional correspondente pelo SEFIP, o sistema gerador da GFIP, a cargo da cooperativa de produção.

Em relação ao cooperado filiado à cooperativa de trabalho, os códigos de ocorrência indicativos de exposição a agentes nocivos devem ser informados quando a atividade exercida no tomador, ou no local por ele indicado, permita a concessão de aposentadoria especial. Esta informação não gera cálculo de contribuição adicional a cargo

\footnotetext{
${ }^{174}$ Tal situação ocorre quando o trabalhador consta em GFIPs geradas em movimentos diferentes, com a remuneração desmembrada em cada uma delas, quando, por exemplo, o empregador é obrigado a emitir guias para distintos tomadores de seus serviços.

${ }^{175}$ O Perfil Profissiográfico Previdenciário (PPP) é um formulário com campos a serem preenchidos com todas as informações relativas ao empregado, como a atividade que exerce, o agente nocivo ao qual é exposto, a intensidade e a concentração do agente e exames médicos clínicos, além de dados referentes à empresa. Ele deve ser preenchido pelas empresas que exercem atividades que exponham seus empregados a agentes nocivos químicos, físicos, biológicos ou associação de agentes prejudiciais à saúde ou à integridade física, os quais dão origem à concessão de aposentadoria especial após 15, 20 ou 25 anos de contribuição. Além disso, todos os empregadores e instituições que admitam trabalhadores como empregados, além da execução do Programa de Prevenção de Riscos Ambientais e do Programa de Controle Médico de Saúde Ocupacional, de acordo com Norma Regulamentadora $n^{\circ} 9$ da Portaria $n^{\circ}$ 3.214/78 do MTE, também devem preencher o PPP. A Instrução Normativa/INSS/DC no 99 de 05/12/2003 determina que, após a implantação do PPP em meio magnético pela Previdência Social, esse documento será exigido para todos os segurados, independentemente do ramo de atividade da empresa e da exposição a agentes nocivos. Em outros termos, o preenchimento do PPP passará a ser obrigatório para todas as empresas e para todos os seus empregados.
} 
da cooperativa de trabalho, pois este encargo é do tomador dos serviços da cooperativa, conforme a previsão do artigo 22, inciso IV, da Lei de Custeio da Previdência Social, combinado com o artigo $1^{\circ}$ da Lei $\mathrm{n}^{\circ} 10.666$, de 2003.

Outros eventos da vida laboral e previdenciária do trabalhador são igualmente relevantes para o INSS, seja porque ensejam benefícios, seja porque tem como consequência a aquisição ou perda de direitos. Nesse sentido, o empregador deve noticiar na GFIP todos os eventos que impactam a vida do trabalhador, tais como a rescisão do contrato de trabalho e o tipo de rescisão ocorrida; a transferência de estabelecimento; o afastamento temporário por motivo de acidente do trabalho (seja por mais ou por menos de 15 dias); a recidiva do afastamento pelo mesmo motivo; o afastamento por doença, independentemente do prazo; a recidiva na doença; a licença-maternidade mesmo que seja a decorrente de adoção; o afastamento para prestar o serviço militar; a aposentadoria; o falecimento do trabalhador etc. Todos esses eventos, e outros mais, são codificados permitindo sua informação na guia da previdência. ${ }^{176}$

Anotados os identificadores dos empregadores e dos trabalhadores que devem constar da GFIP, analisemos agora os dados financeiros, chamados de movimento financeiro pelo Manual da GFIP, que são os formadores da base de cálculo da contribuição previdenciária incidente sobre a folha de pagamento, da base de cálculo para $\mathrm{o}$ recolhimento do FGTS, e ainda, os dados que permitirão ao INSS calcular o salário-debenefício dos segurados que eventualmente precisem de prestações da Previdência Social.

\subsection{Os dados previdenciários e a sua destinação}

A empresa deverá apresentar mensalmente a GFIP. Para tanto, deverá apontar a que competência, assim entendidos o mês e o ano, as informações se referem. Existem códigos específicos, constantes do Manual de GFIP, que se vinculam ao tipo de Guia que a empresa está apresentando. O mais comum, que contempla informações à Previdência Social e ao FGTS, é o código 115. Há a possibilidade de informação de GFIP sem movimento para a Previdência Social, para o FGTS, ou para ambos. Mesmo nesses casos, persiste a obrigatoriedade da entrega da Guia.

Se a empresa for optante pelo sistema simplificado de tributação das microempresas e empresas de pequeno porte, denominado Simples Nacional e, portanto,

\footnotetext{
${ }^{176}$ Conferir tabela reproduzida do Manual da GFIP, com os códigos de movimentação do trabalhador no
} Anexo II. 
em regra, contar com a substituição tributária das contribuições previdenciárias patronais incidentes sobre a folha de pagamento, ${ }^{177}$ deverá informar tal opção, e o sistema SEFIP não calculará a quota patronal, calculando somente a parte retida dos trabalhadores.

\subsubsection{Financiamento do seguro acidente do trabalho}

O financiamento do seguro acidente do trabalho (SAT), segundo alguns normativos RAT, é realizado com a contribuição da empresa sobre a remuneração paga aos seus empregados e trabalhadores avulsos, segundo as alíquotas de 1, 2 ou 3\%, conforme o grau de risco de sua atividade econômica. ${ }^{178}$

Segundo o parágrafo $5^{\circ}$ do artigo 202 do Regulamento da Previdência Social (RPS), aprovado pelo Decreto $\mathrm{n}^{\circ} 3.048$, de 1999, é de responsabilidade da empresa realizar seu enquadramento quanto ao grau de risco de seu objetivo empresarial, e ela o faz encontrando a CNAE Preponderante, que é determinada pelo enquadramento da atividade econômica preponderante da empresa na tabela constante do Anexo V do Regulamento da Previdência Social. ${ }^{179} \mathrm{O}$ enquadramento na atividade preponderante deve ser feito segundo as orientações da Instrução Normativa RFB n⿳ 971, de 2009, que dispõe sobre normas gerais de tributação previdenciária e de arrecadação das contribuições sociais administradas pela Receita Federal do Brasil, RFB.

Para garantir que o chamado autoenquadramento seja preservado quando do preenchimento da GFIP, a empresa deve informar a alíquota SAT a ela aplicável, não sendo de preenchimento automático pelo sistema, muito embora esse tenha dados suficientes para o preenchimento, uma vez que, como visto no item 4.2 acima, a classificação CNAE da empresa deve ser informada ao programa informatizado. Já o acréscimo das alíquotas em virtude de exposição do segurado aos agentes nocivos é automaticamente calculado pelo SEFIP, programa gerador da GFIP, com base no código de ocorrência informado em relação a cada trabalhador.

\footnotetext{
${ }^{177}$ As empresas optantes pelo Simples Nacional e tributadas com base no Anexo IV da Lei Complementar $\mathrm{n}^{\circ}$ 123, de 2006, não possuem a substituição tributária da contribuição patronal sobre a folha de pagamento.

${ }^{178}$ Lei $n^{\circ} 8.212$, de 1991, artigo 22, inciso II

${ }^{179} \mathrm{O}$ artigo 72, $\S 1^{\circ}$, inciso II da Instrução Normativa RFB $\mathrm{n}^{\mathbf{0}}$ 971, de 2009, explicita que atividade preponderante é aquela atividade econômica que ocupa maior número de segurados empregados e avulsos na empresa.
} 


\subsubsection{Fator Acidentário de Prevenção}

A Lei $\mathrm{n}^{\circ} 10.666$, de 2003, em seu artigo 10, determina que a alíquota que financia o seguro acidente do trabalho de 1, 2 ou $3 \%$ poderá ser reduzida à metade ou acrescida em $100 \%$, conforme dispuser o regulamento, em razão do desempenho da empresa em relação às demais empresas do mesmo segmento econômico, quanto à frequência, gravidade e custo dos acidentes do trabalho que vier a causar. Nesse contexto, surge o Fator Acidentário de Prevenção (FAP), criado pelo Decreto $n^{\circ}$ 6.042, de 2007, que inseriu o artigo 202-A no RPS.

Anualmente, e com base nos dados extraídos dos dois últimos anos, o Ministério da Previdência Social publica a lista do FAP por empresa. Esse fator, numa visão resumida, é calculado com base nos benefícios concedidos (frequência), duração dos mesmos (gravidade), e valor da renda mensal do benefício (custo) de cada acidente do trabalho sofrido pelos segurados de cada empresa. Comparam-se esses dados com os dados das demais empresas da região que atuam no mesmo segmento econômico e com os dados da própria empresa do ano anterior. A empresa que reduzir a ocorrência de sinistros terá, em face de sua evolução na proteção da saúde de seus segurados, um FAP menor que a unidade (FAP < 1), pagando, portanto, sua contribuição ao SAT com uma menor alíquota.

Assim, uma empresa que investe no meio ambiente do trabalho, tornando-o salubre, terá parte de seu investimento amortizado por meio de uma redução de gastos com contribuição social previdenciária, uma vez que, por registrar menor quantidade de acidentes do trabalho, utiliza uma alíquota de contribuição ao SAT menor que aquela aplicável à sua atividade econômica. Em contrapartida, se não investir em políticas protetivas e ocasionar maior número de acidentes do trabalho que suas congêneres, terá um FAP maior que um, portanto, pagará sua contribuição com uma alíquota SAT agravada. Quando isso ocorrer, deverá informar o multiplicador FAP conforme o desempenho da empresa, dentro da respectiva atividade, apurado segundo as orientações estabelecidas no Decreto $n^{0}$ 6042, de 12/02/2007. Se indisponível ou inexistente, o Fator Acidentário de Prevenção a ser registrado pela empresa deverá assumir valor igual a 1,00. O SEFIP multiplicará o FAP pela alíquota RAT, para encontrar o "RAT ajustado", que será utilizado para o cálculo das contribuições devidas. 


\subsubsection{Código de outras entidades (terceiros)}

Embora não se tratem de contribuições destinadas ao financiamento da seguridade social, quanto menos ao custeio da Previdência Social, as empresas são obrigadas a recolher as contribuições aos terceiros, ${ }^{180}$ assim entendidas as entidades constantes do sistema "S", SESC, SESI, ${ }^{181}$ SENAI, ${ }^{182}$ SENAC ${ }^{183}$ SEBRAE,${ }^{184}$ SENAR ${ }^{185}$ etc., que se destinam ao aprimoramento profissional de seus associados, assim entendidos aqueles trabalhadores vinculados a estas entidades por força da atividade econômica de seu empregador, como ocorre no caso da sujeição sindical. Para tanto, devem informar o código de outras entidades e fundos para os quais a empresa está obrigada a contribuir, de acordo com a tabela de alíquotas por FPAS constante dos anexos da mencionada Instrução Normativa RFB no 971.

O código de outras entidades e fundos deve estar vinculado ao FPAS informado, ressalvando-se que aquele código é encontrado somando-se os códigos correspondentes a cada entidade para a qual há contribuição.

Tal procedimento permite que, no caso de convênio entre a empresa e terceiro, ou seja, havendo recolhimento direto à entidade e/ou ao fundo beneficiado, não englobado na guia de recolhimento das contribuições previdenciárias (GPS), o código da entidade para a qual há convênio não seja somado, permitindo ao INSS o repasse do quantum devido a cada um, sem alteração das informações gerais prestadas pelo contribuinte.

\subsubsection{Valores pagos a cooperativas de trabalho}

Segundo o artigo 22, inciso IV, da Lei $\mathrm{n}^{\circ}$ 8.212/91, a empresa tomadora dos serviços prestados por cooperados por intermédio de cooperativas de trabalho deve

\footnotetext{
${ }^{180}$ Ver permissivo constitucional da exação no art 240 da Carta de 1988.

181 Conforme artigo 30 da Lei $\mathrm{n}^{\circ}$ 8.036, de 1990, a contribuição ao SESC e SESI é de 1,5\% sobre a remuneração paga aos seus empregados.

${ }^{182}$ Lei $n^{\circ} 5.107$, de 1966, art. 23, estipula em $1 \%$ a contribuição das indústrias ao SENAI.

${ }^{183}$ É de $1 \%$ a contribuição ao SENAC incidente sobre a folha de pagamento dos empregados do comércio, segundo o art. $4^{\circ}$ do Decreto-Lei $n^{\circ} 8.621 / 46$.

${ }^{184} \mathrm{O}$ art. $3^{\circ}, \S 3^{\circ}$, da Lei ${ }^{\circ} 8.029,1990$, estipula que a contribuição ao SEBRAE é de $0,3 \%$ sobre a folha de pagamento.

${ }^{185} \mathrm{O}$ art. $3^{\circ}$ da Lei $\mathrm{n}^{\circ}$ 8.315, de 1990 , determinava a contribuição de $2,5 \%$ sobre a remuneração dos empregados pelas empresas agroindustriais, agropecuárias, extrativistas vegetais e animais, cooperativistas rurais e sindicatos patronais rurais. Hoje, em face do disposto na Lei 8.870 , art. $25, \S 1^{\circ}$, há substituição tributária sobre esse valor, incidindo uma alíquota de $0,25 \%$ sobre a receita bruta de venda de sua produção própria.
} 
recolher $15 \%$ sobre o valor total da nota fiscal ou fatura de prestação de serviços emitida pela cooperativa. Na GFIP, com o fito de prestar as informações e recolher a contribuição, deve ser informado o montante dos valores brutos das notas fiscais ou faturas de prestação de serviços emitidas pelas cooperativas no decorrer do mês.

Como dito anteriormente, ao investigarmos as informações do trabalhador constante da Guia, se o cooperado prestar serviços por intermédio de cooperativa de trabalho e estiver exposto aos agentes nocivos em níveis que ensejem aposentadoria especial, estes deverão constar da GFIP. Segundo o disposto no artigo $1^{\circ}$ da Lei $n^{\circ} 10.666$, de 2003, quando o trabalhador exposto for um cooperado prestando serviços por intermédio de uma cooperativa de trabalho, caberá ao tomador desses serviços arcar com o adicional do SAT, também denominado GILRAT, incidente sobre o valor da nota fiscal ou fatura desses serviços emitida pela cooperativa. A alíquota suplementar deve ser, nesses casos, de nove, sete ou cinco pontos percentuais, dependendo do agente nocivo a que o trabalhador estiver exposto, ensejar aposentadoria aos quinze, vinte ou vinte e cinco anos de trabalho.

Para implementar o comando legal explicitado, o tomador de serviços deverá informar o montante dos valores brutos das notas fiscais ou faturas de prestação de serviços sobre o qual incide a contribuição de $15 \%$, mais a contribuição de 9,7 , ou $5 \%$ referida no artigo $1^{\circ}, \S 1^{\circ}$, da Lei $\mathrm{n}^{\circ} 10.666$, de 2003, perfazendo alíquotas totais de 24, 22 , ou $20 \%$.

A base de cálculo prevista pela Lei $n^{\circ} 10.666$ é o valor total da prestação de serviços em condições especiais pela cooperativa e constante na nota fiscal, fatura desses serviços. Tal disposição foi regulamentada no sentido de que, havendo o fornecimento de material ou a utilização de equipamentos, próprios ou de terceiros, exceto equipamentos manuais, o valor destes pode ser excluído da base de cálculo, conforme estabelece a Instrução Normativa RFB n 971, de 2009, que dispõe sobre normas gerais de tributação e arrecadação das contribuições previdenciárias.

Para permitir o cruzamento das informações, a cooperativa de trabalho deverá informar o montante dos valores brutos da nota fiscal ou faturas emitidas a cada contratante no decorrer do mês.

\subsubsection{Receitas de eventos desportivos e patrocínio}


A Lei de Custeio da Previdência determina em seu artigo $22, \S \S 7^{\circ}$ a $9^{\circ}$, que a entidade promotora de eventos desportivos, a empresa patrocinadora, a transmissora de espetáculos, a licenciadora de marcas e a empresa de publicidade devem reter e recolher $5 \%$ do valor total da receita bruta decorrente de espetáculos desportivos, em qualquer modalidade, de que participe associação desportiva que mantenha equipe de futebol profissional, em todo o território nacional, inclusive jogos internacionais. Essa contribuição sobre a receita da associação desportiva que mantém equipe de futebol profissional substitui a contribuição devida por estas associações incidente sobre a remuneração paga a seus empregados e também a destinada a financiar o seguro acidente do trabalho.

As empresas mencionadas, inclusive aquelas optantes pelo SIMPLES, devem informar em campo próprio da GFIP os valores pagos a título de patrocínio, licenciamento de marcas e símbolos, publicidade, propaganda e transmissão de espetáculos para a associação desportiva que mantenha equipe de futebol profissional, nos termos do Manual da GFIP.

\subsubsection{Comercialização da produção rural}

Também para as pessoas dedicadas à produção rural ocorre substituição tributária da contribuição previdenciária incidente sobre a remuneração. O produtor rural pessoa física, ${ }^{186}$ o produtor pessoa jurídica ${ }^{187}$ e a agroindústria ${ }^{188}$ contribuem sobre a receita bruta proveniente da comercialização da sua produção, em substituição à quota patronal da contribuição previdenciária incidente sobre a remuneração paga aos segurados empregados e avulsos, além do percentual destinado ao financiamento do Seguro Acidente do Trabalho.

O segurado especial, ${ }^{189}$ por seu turno, que também contribui com a mesma alíquota e sobre a mesma base do produtor rural pessoa física, não o faz em substituição da contribuição previdenciária sobre a folha de empregados e avulsos, até porque não os tem de maneira regular. Essa contribuição é, na verdade, a base de seu salário de contribuição como segurado obrigatório da Previdência Social, e não como equiparado à empresa, como

\footnotetext{
${ }^{186}$ Art. 25 da Lei $\mathrm{n}^{\circ}$ 8.212, de 1991. Alíquota de $2 \%+0,1 \%$ sobre a receita bruta da comercialização da produção.

${ }^{187}$ Art. 25 da Lei ${ }^{\circ} 8.870$, de 1994. Alíquota de 2,5\% + 0,1\% sobre a receita bruta da comercialização da produção.

${ }^{188}$ Art. 22-A da Lei n ${ }^{\circ} 8.212$, de 1991. Alíquota de 2,5\% + 0,1\% sobre a receita bruta da comercialização da produção.

${ }^{189}$ Conceituraremos e teceremos maiores considerações sobre o segurado especial no capítulo 6, item 6.2.
} 
empregador, ${ }^{190}$ não substituindo, portanto, a quota patronal prevista no artigo 22 da Lei de Custeio.

O recolhimento das contribuições acima apontadas é realizado de formas distintas. O produtor rural pessoa jurídica e a agroindústria recolhem, eles próprios, os valores incidentes sobre a receita oriunda da comercialização da sua produção. Cabe a eles informar na GFIP, em campo próprio, esse valor, que é a base de cálculo de sua contribuição à Previdência Social.

Já no caso do produtor rural pessoa física há, além da substituição tributária da base de cálculo da sua contribuição, também substituição quanto à responsabilidade pelo recolhimento da contribuição, uma vez que cabe ao adquirente do produto rural da pessoa física a retenção e o recolhimento do valor devido à titulo de contribuição previdenciária. Assim, ao adquirente resta o dever de informar na GFIP a retenção efetuada do produtor rural pessoa física. Exceção a esta substituição da responsabilidade pelo recolhimento ocorre quando o produtor rural pessoa física vende sua produção no varejo ou a outra pessoa física, cabendo ao próprio produtor pessoa física a obrigação de recolher o valor devido sobre a comercialização da produção e de informar a ocorrência na sua própria GFIP.

\subsubsection{Prestação de serviços mediante cessão de mão-de-obra: retenção dos $11 \%$}

A Lei n ${ }^{\circ}$ 9.711, de 1998, alterou a redação do artigo 31 da Lei n ${ }^{\circ} 8.212$, de 1991, e introduziu a antecipação das contribuições previdenciárias devidas pelas empresas prestadoras de serviços mediante cessão de mão-de-obra, representada pela retenção de $11 \%$ sobre o valor da nota fiscal, fatura ou recibo deste tipo de prestação de serviços.

Segundo o parágrafo $3^{\circ}$ do mencionado artigo 31 da Lei de Custeio, ocorre cessão de mão-de-obra quando a prestadora de serviços, realizando serviços contínuos, disponibiliza seus trabalhadores para a tomadora dos serviços, nos locais por ela indicados, desde que estes não sejam as dependências da própria prestadora dos serviços contratados.

Esclarece o parágrafo $4^{\circ}$ do artigo 31 da Lei n ${ }^{\circ}$ 8.212, de 1991 que não são todos os serviços prestados mediante cessão de mão-de-obra que estão sujeitos à retenção. Somente o são aqueles elencados no referido parágrafo: limpeza, conservação e zeladoria; vigilância e segurança; empreitada de mão-de-obra; e contratação de trabalho temporário na forma da

${ }^{190}$ Cf. IBRAHIM, Fábio Zambitte. Curso de Direito Previdenciário. 16a ed. Niterói: Ed. Impetus, 2011. p. 278. 
Lei $\mathrm{n}^{\circ}$ 6.019, de 1974, e os demais a serem contemplados no Regulamento da Previdência Social (RPS). ${ }^{191}$

Esmiuçando os ditames legais acima mencionados, encontraremos necessidade de maior reflexão sobre três conceitos: continuidade dos serviços prestados; disponibilização de trabalhadores e local da prestação de serviços.

Por disponibilização de trabalhadores entende-se a efetiva cessão dos empregados da empresa contratada para a contratante, nas dependências desta ou onde ela indicar, deixando de ter a prestadora de serviços a força do labor dos seus trabalhadores cedidos. Tal conceituação, que à primeira vista parece tautológica, permite - quando bem entendida - que se afira a efetiva cessão de mão-de-obra, uma vez que a empresa contratada, quando cede seus trabalhadores, com eles não pode contar para a realização de qualquer outra tarefa, exceto aquela estabelecida com seu contratante.

Enfrentemos agora a questão da continuidade dos serviços prestados por meio de cessão de mão-de-obra. Por expressa disposição da Instrução Normativa RFB nº 971, de 2009, no parágrafo $2^{\circ}$ do artigo 115 , a continuidade da prestação dos serviços não deve ser entendida como um tempo ou ainda uma frequência da efetiva contratação da prestadora de serviços. Deve, sim, ser aferida quanto à necessidade da contratante, ou seja, se a utilidade daquele serviço prestado pela contratada se repetirá para a tomadora do serviço de modo contínuo, de modo perene, mesmo que com amplo intervalo de tempo entre os eventos que demandem a prestação de serviço.

Com exemplo se entende melhor: a prestação de um serviço de manutenção de uma máquina ou um equipamento é uma necessidade contínua de uma empresa que possua tal máquina ou equipamento, sob pena de não poder utilizar o seu bem por falha na manutenção dele. A periodicidade dessa manutenção depende do tipo de equipamento, de seu uso e das condições nas quais ele ocorre, de sua idade, entre outros fatores. Portanto, se a prestação de serviços de manutenção for realizada com disponibilização de pessoal e nas dependências da contratante ou onde ela indicar, acontecerá mediante cessão de mão-deobra, e, portanto, deverá sofrer a antecipação tributária previdenciária instituída pela Lei $\mathrm{n}^{\circ}$ 9.711, de 1998, que alterou o artigo 31 da Lei de Custeio.

Assentemos. Ocorre prestação de serviços mediante cessão de mão-de-obra quando a prestadora disponibiliza seus trabalhadores (deixando de com eles contar para outras

\footnotetext{
${ }^{191} \mathrm{O}$ artigo 219 , em lista exaustiva constante do parágrafo $2^{\circ}$, contempla em seus 25 incisos as atividades que, se prestadas mediante cessão de mão-de-obra, devem sofrer a retenção dos $11 \%$.
} 
tarefas que não as contratadas no caso em análise), para prestar serviços que sejam de necessidade contínua da tomadora, nas dependências dela, ou em local por ela indicado.

Por todo o exposto, podemos concluir que, havendo contratação de algum serviço constante do rol exaustivo do artigo $219, \S 2^{\circ}$ do RPS, e sendo este serviço prestado mediante cessão de mão-de-obra, o contratante deverá reter e recolher $11 \%$ sobre o valor da nota fiscal, fatura, ou recibo emitido pelo prestador, por meio da Guia de Previdência Social (GPS). ${ }^{192}$

Por seu turno, a empresa que presta serviços por meio de cessão de mão-de-obra deverá preencher GFIP específica ${ }^{193}$ para cada tomador de seus serviços, destacando as retenções sofridas, as quais serão objeto de compensação, ${ }^{194}$ e informar ainda os segurados que prestaram serviços para aquele tomador naquele mês de competência da GFIP. Quando seus trabalhadores prestarem serviços ao contratante em condições que permitam a concessão de aposentadoria especial, segundo o disposto no artigo $6^{\circ}$ da Lei $n^{\circ} 10.666$, de 2003, deverá, como visto no subitem 4.4.1, acrescer alíquotas de 4, 3, ou $2 \%$.

\subsubsection{Os dados financeiros dos trabalhadores}

Sendo a Guia de Informações à Previdência Social e ao FGTS destinada ao povoamento do banco de dados do INSS com as informações de interesse da categoria, o documento de nossa análise não poderia deixar de conter, ao lado das informações financeiras da empresa, as mesmas notícias relativas aos trabalhadores.

A empresa, ou o a ela equiparado, obrigados ao preenchimento da GFIP, devem inserir, além dos dados cadastrais vistos no subitem 4.3, a remuneração ${ }^{195}$ paga, devida ou creditada ao trabalhador, excluindo a parcela relativa ao $13^{\circ}$ salário, ou seja, seu salário-decontribuição, base de cálculo das contribuições à Previdência Social. Convém salientar que

\footnotetext{
192 O documento de arrecadação das contribuições previdenciárias é denominado Guia da Previdência Social (GPS). Nas contribuições recolhidas a título de retenção de $11 \%$ sobre o valor da prestação de serviços mediante cessão de mão-de-obra, deve-se usar o código 2631 e o CNPJ do prestador do serviços na GPS.

${ }^{193}$ A GFIP específica por tomador de serviços tem o código 150, segundo o Manual da GFIP.

${ }^{194}$ As Instruções Normativas RFB no 971, de 2009, e RFB nº 900, de 2008, disciplinam o procedimento de compensação e restituição de contribuições previdenciárias. Em síntese, a compensação dos valores retidos pelo tomador dos serviços pode ser realizada na própria competência em que se sofreu a retenção ou nas subsequentes, neste caso, acrescidas de juros Selic, desde que informada em GFIP.

195 As parcelas integrantes do salário de contribuição dos segurados estão elencadas no artigo 28 da Lei ${ }^{\circ}$ 8.212 , de 1991, com especial destaque para o disposto no $\S 9^{\circ}$ do mencionado artigo, que elenca as parcelas não integrantes do salário de contribuição.
} 
sobre o salário-de-contribuição incidem tanto a quota patronal ${ }^{196}$ quanto o quinhão devido pelo trabalhador, ${ }^{197}$,o qual deve, nos termos da Lei de Custeio, ${ }^{198}$ ser retido e recolhido pela empresa.

Nos termos da CLT, se o trabalhador for um empregado, sua base de cálculo das contribuições previdenciária será o total da sua remuneração mensal, incluindo suas férias, quando gozadas, e o terço constitucional sobre elas incidente. Sendo o trabalhador um avulso, para se encontrar seu salário de contribuição, deve-se acrescer ao valor de sua remuneração o valor de suas férias e do terço constitucional sobre elas incidentes, uma vez que tal categoria de trabalhador recebe suas férias de maneira fracionada, ou seja, mensalmente. No caso dos contribuintes individuais, ${ }^{199}$ a base de cálculo é o valor da remuneração paga ou a ele creditada.

Quando o segurado possui múltiplos vínculos, isto é, exerce mais de uma atividade remunerada, cada tomador de seus serviços pessoais deve incluí-lo na GFIP, informando o total da remuneração por ele auferida, segundo os critérios referentes ao tipo de vínculo que se estabelece em cada relação de trabalho. Também nesses casos a empresa deve utilizar o campo "valor descontado do segurado" para informar o valor retido, uma vez que o trabalhador pode ter optado pela realização do desconto por outro empregador ou já ter recolhido a contribuição no seu limite máximo em outro vínculo.

Sabe-se que, por vezes, o contrato de trabalho deixa de ser temporariamente cumprido em face da impossibilidade de sua execução, como ocorre, por exemplo, nos casos de afastamentos por doença, por licença-maternidade ou prestação de serviço militar. Nessas circunstâncias, a empresa deve informar, além do código referente à ocorrência que causou a interrupção ou a suspensão do contrato de trabalho, a remuneração paga ao segurado relativa aos dias efetivamente trabalhados durante o mês acrescida da remuneração pertinente ao período do afastamento. Para explicitar a situação atípica, é usada a data do código da ocorrência, que informa ao INSS o início do benefício cabível.

\footnotetext{
${ }^{196}$ As alíquotas referentes à quota patronal incidente sobre as diversas formas de contratação de prestação de serviços se encontram elencadas nos diversos incisos do artigo 22 da Lei de Custeio da Previdência Social.

197 As contribuições dos trabalhadores, sempre respeitados os limites mínimos e máximos do salário de contribuição, se encontram dispostas nos artigos 20 e 21 da Lei n 8.212 , de 1991.

198 Art. 30, inciso I, da Lei $n^{\circ} 8.212$, de 1991, com a redação da Lei $n^{\circ} 11.933$, combinado com o art. $4^{\circ}$ da Lei ${ }^{\circ} 10.666$, de 2003.

199 A Lei de Benefícios, Lei $n^{\circ}$ 8.213, de 1991, elenca no artigo 11, inciso V, os segurados que são considerados contribuintes individuais. Podemos, em livre interpretação, entender por autônomos empresários, cooperados e todas as demais pessoas físicas que trabalham sem vínculo de emprego e não se enquadram na categoria de avulsos como domésticos e segurados especiais.
} 
O $13^{\circ}$ salário do segurado empregado deve ser informado em campo próprio, sempre que houver o pagamento de parcela. Ressalte-se que o $13^{\circ}$ salário só é base de cálculo da contribuição previdenciária quando do pagamento da parcela final, em 20 de dezembro, ou no caso de rescisão, exceto por justa causa, aposentadoria sem continuidade da relação de emprego ou falecimento do segurado empregado.

Assim, havendo o correto preenchimento das informações da empresa e do trabalhador, o sistema SEFIP automaticamente poderá mensurar a base de cálculo das contribuições previdenciárias, explicitando sua face de obrigação acessória tributária da GFIP. Quando isso ocorre, os campos da GFIP 'base de cálculo da Previdência Social' e 'remuneração sem $13^{\circ}$ salário' tendem a conter o mesmo valor.

Porém, em três situações, essa igualdade não acontecerá, em decorrência das consequências distintas para as contribuições previdenciárias e para o recolhimento do FGTS. São elas os afastamentos por acidente do trabalho, o afastamento por serviço militar obrigatório e a existência de recolhimento complementar para o FGTS. ${ }^{200}$ Nesses casos, caberá ao empregador preencher o corretamente o campo 'base de cálculo da Previdência Social' com o valor devido, por óbvio menor que o constante do campo 'remuneração sem $13^{\circ}$ salário', que é base do recolhimento do FGTS. Devemos também recordar que alguns benefícios previdenciários são pagos pela empresa e por ela compensados quando do pagamento das contribuições devidas à Previdência Social. São estes o salário-família e o salário-maternidade.

O salário-família é um benefício previdenciário devido ao segurado empregado e ao trabalhador avulso de baixa renda ${ }^{201}$ que possuírem filhos de até quatorze anos ou inválidos, desde que cumpridos dois requisitos: para os filhos menores de seis anos o segurado deverá apresentar o atestado de vacinação obrigatória, e para os filhos que tenham entre sete e quatorze anos, deverá ser apresentado, semestralmente, o atestado de frequência escolar. Assim procedendo, o empregado ou o avulso receberão da empresa ou do sindicato, ou ainda do Órgão Gestor de Mão-de-Obra, OGMO, consoante o caso,

\footnotetext{
${ }^{200}$ O Manual da GFIP, aprovado pela IN 880, de 2008, apresenta no item 8, subitem 8.1, do Capítulo IV, as situações que ensejam o recolhimento complementar, dentre as quais, por serem as mais usuais, podem-se citar a transformação pelo INSS do benefício auxílio-doença em auxílio-doença acidentário; reclamatória trabalhista com reconhecimento de depósitos devidos de FGTS; verbas pagas em decorrência de acordos coletivos etc.

${ }^{201}$ Segundo os valores atualizados pela Portaria Interministerial $\mathrm{n}^{\circ} 2$, de 6 de janeiro de 2012, o trabalhador que possua renda de até $\mathrm{R} \$ 608,80$ mensais receberá $\mathrm{R} \$ 31,22$ por filho. Já o empregado ou avulso que receber entre $\mathrm{R} \$ 608,81$ e $\mathrm{R} \$ 915,05$ terá o valor da quota do salário-família reduzida para $\mathrm{R} \$ 22,00$.
} 
juntamente com sua remuneração, o salário-família a que fizer jus. Tal situação deverá constar dos campos próprios da GFIP, ensejando a compensação.

Quanto ao salário-maternidade, o mesmo procedimento, pagamento e posterior compensação, deve acontecer, quer seja a gestante ou adotante empregada, quer seja ela avulsa. $^{202} \mathrm{O}$ manual da GFIP contém todas as informações para que a empresa, o OGMO ou ainda o sindicato informem a ocorrência do pagamento do benefício previdenciário e sejam compensados, na mesma ou em outras competências, pelo valor despendido.

O trabalhador eleito para exercer mandato sindical mantém, no RGPS, a mesma categoria de antes da investidura no cargo, e as informações a ele relativas devem ser prestadas de acordo com a responsabilidade pelo pagamento do dirigente sindical, respeitados os vínculos de trabalho que eles ostentam.

Em relação ao dirigente sindical que mantém a qualidade de empregado e que continue sendo remunerado exclusivamente pela empresa de origem, essa deverá prestar, normalmente, todas as informações do dirigente sindical como seu empregado. Se o dirigente eleito for remunerado exclusivamente pelo sindicato, caberá ao segundo elaborar guias distintas para cada empresa que ceda trabalhadores para o exercício de mandato sindical, seguindo, para tanto, as orientações contidas no Manual da GFIP. ${ }^{203}$ No caso de dirigente sindical avulso, valem, em regra, as mesmas orientações, ${ }^{204}$ mudando-se o que deve ser mudado. O contribuinte individual, inclusive o empresário, por óbvio não mantém vínculo com a empresa, devendo as informações serem prestadas pelo próprio sindicato. ${ }^{205}$

\subsection{Os dados relativos ao FGTS e sua destinação}

A lei que instituiu a GFIP, Lei $n^{\circ} 9.528$, de 1997, a concebeu como documento de informações à Previdência Social e ao FGTS, mas também como guia de recolhimento desse. Hoje, em face da alteração promovida pela Caixa Econômica Federal, agente operador do fundo, o documento de arrecadação é a Guia de Recolhimento do FGTS (GRF), gerada pelo mesmo programa utilizado para o preenchimento da GFIP, o SEFIP.

\footnotetext{
${ }^{202}$ As seguradas contribuinte individual, domésticas e especiais recebem o salário-maternidade diretamente do INSS.

${ }^{203}$ Item 2.1 do Capítulo IV do Manual da GFIP, aprovado pela IN RFB n ${ }^{\circ} 880$.

${ }^{204} \mathrm{O}$ item 2.2 do Capítulo IV do Manual da GFIP contém as devidas orientações.

${ }^{205}$ Os esclarecimentos sobre o preenchimento da GFIP, neste caso, constam do item 2.3 do Capítulo IV do Manual da GFIP.
} 
A dupla finalidade da GFIP, prestar informações à Previdência Social e ao FGTS, se funda na similitude da base de cálculo dos dois tributos ${ }^{206}$ e na finalidade social dessas contribuições. Os recolhimentos mensais para o FGTS, com alíquota de $8 \%$ sobre a remuneração paga, devida ou creditada a cada trabalhador no mês, constituem responsabilidade do empregador. Importantíssimo ressaltar, como explicita o artigo 15 da Lei $\mathrm{n}^{\circ} 8.036$, que a empresa deve depositar o FGTS devido na conta vinculada de cada trabalhador, ou seja, o depósito deve ser individualizado. Tal determinação é reiterada na mencionada Instrução Normativa $n^{\circ}$ 99, de 2012, que, no artigo 35, preceitua ser "a individualização do valor devido ou recolhido de FGTS na conta vinculada do empregado" obrigação do empregador.

A contratação de menor aprendiz tem alíquota reduzida (2\%), a mesma que era aplicável ao trabalhador contratado por prazo determinado, nos termos da Lei ${ }^{\circ}$ 9.601/98 e vigente no período compreendido entre 01/1998 a 01/2003.

A Lei $\mathrm{n}^{\circ}$ 8.036, de 1990, que dispõe sobre o FGTS, estipula em seu artigo 15 que integram a remuneração para fins de cálculo de depósito fundiário as parcelas de que tratam os artigos 457 e 458 da CLT, ${ }^{207}$ além da gratificação de Natal. Expressamente, no parágrafo $6^{\circ}$ do mesmo artigo 15 , a Lei $n^{\circ} 8.036$ determina que não se incluem na remuneração as parcelas mencionadas no artigo 28, §9º da Lei nº 8.212, de 1991.

A Instrução Normativa ${ }^{\circ} 99$ do Ministério do Trabalho e Emprego, de setembro de 2012, dispõe sobre a fiscalização do FGTS e explicita em seu artigo $8^{\circ}$, em rol exemplificativo, as verbas que ostentam natureza salarial e, portanto, integram a base de cálculo do FGTS. O artigo $9^{\circ}$ do mesmo diploma legal elenca as verbas sobre as quais não incide o FGTS. Cabe à empresa, ou ao equiparado, informar na GFIP o total da remuneração sobre a qual incidirá o recolhimento ao FGTS.

Ao longo deste capítulo, destacamos que a GFIP corretamente preenchida viabiliza o cumprimento do comando legal, pois ela garante que os dados relativos ao depósito do trabalhador sejam corretamente destinados à sua conta individualizada. Pudemos constatar, também, a magnitude do documento que é o maior veículo de informações sociais previsto

\footnotetext{
${ }^{206}$ Filiamo-nos aos que entendem que o FGTS tem dupla natureza jurídica: tributo para a empresa e salário diferido para o empregado, consoante maiores considerações entabuladas no item 5.2 do Capítulo V do presente trabalho.

${ }^{207} \mathrm{O}$ artigo 457 da CLT assevera que a remuneração é composta pelo salários mais as gorjetas recebidas pelo empregado, além das importância fixas, as comissões, percentagens, gratificações ajustadas, diárias para viagem e abonos pagos pelo empregador, excluindo-se as ajudas de custo e parcelas de diárias para viagem que não excedam 50\% do salário percebido pelo empregado. Já o artigo 458 da Consolidação versa sobre o salário-utilidade.
} 
em nosso ordenamento jurídico. Totalmente prescindível, agora que conhecemos a quantidade de dados afetos ao tomador de serviços, ao trabalhador e ao vínculo que os une, que consta da Guia de Informações ao FGTS e à Previdência Social, tecer maiores comentários sobre sua importância na garantia do gozo dos direitos trabalhistas e previdenciários pelo trabalhador brasileiro. Passaremos, no próximo capítulo, à observação sobre a tutela que a GFIP possui e os destinos das informações que veicula. 


\section{CAPÍTULO 5 - NATUREZA JURÍDICA, FINALIDADE E TUTELA DA GFIP}

\subsection{Natureza jurídica da GFIP}

Ensina De Plácido e Silva que natureza é "a essência, a substância ou a compleição da coisa."208 Partindo dessa definição, podemos dizer que a natureza da coisa põe em evidência sua própria essência ou substância, mostra seus atributos, demonstra aquilo que lhe é intrínseco, inerente. Natureza jurídica seria, portanto, a definição de quais institutos jurídicos se aplicam ao objeto do estudo, em função de suas características, de sua substância. Assim, antes de definirmos qual a proteção que a Guia de Informações ao FGTS e à Previdência Social deve ter, precisamos perquirir qual é sua natureza jurídica, sua essência.

Para tanto, recordemos seu nascimento. Obrigação introduzida pela Lei n ${ }^{\circ} 9528,{ }^{209}$ de 10/12/1997, que alterou a Lei de Custeio da Previdência Social, Lei no 8.212/91, por meio do acréscimo do inciso IV, e seus parágrafos, no artigo 32, a GFIP surge com objetivos bem determinados pelo legislador: informar ao INSS dados relacionados aos fatos geradores de contribuição previdenciária e outras informações de interesse da autarquia.

Além disso, preceitua, de maneira expressa, que esses dados servirão não só como base de cálculo das contribuições devidas ao INSS, como também comporão a base de dados para fins de cálculo e concessão dos benefícios previdenciários. Assim, a GFIP é criada para que os obrigados informem ao INSS os fatos geradores que incorreram no mês e outras informações previstas de interesse do Instituto. E mais, dita que esses dados deverão ser usados na concessão e nos cálculos dos benefícios previdenciários.

\footnotetext{
${ }^{208}$ SILVA, De Plácido e. Vocabulário Jurídico. 16. ed. Rio de Janeiro: Ed. Forense, 1999. p.550.

${ }^{209}$ Lei 9528/97, que resultou da conversão da MP 1.596-14, de 10/11/97.
} 
É importante, para efeitos de análise da evolução dos procedimentos, lembrarmos que, anteriormente à vigência da Lei $n^{\circ} 9.528 / 97$, praticamente ${ }^{210}$ não havia previsão da prestação de informações mensais aos órgãos de arrecadação e fiscalização ${ }^{211}$ das contribuições previdenciárias. Obviamente, a ausência de informações prévias tornava os órgãos tributários menos eficientes, pois, para a fiscalização das contribuições previdenciárias, tornava-se imperiosa a ida de um fiscal ao estabelecimento do contribuinte.

Em outro giro, para a obtenção de um benefício previdenciário, o segurado deveria, quando do pedido, comprovar sua condição e mais, demonstrar o seu salário-decontribuição. $^{212} \mathrm{O}$ procedimento dificultava a agilidade do processo, tanto devido às incumbências do trabalhador, quanto às do Instituto Previdenciário, pois o servidor deveria analisar a documentação necessária para a concessão de aposentadoria por tempo de serviço ou mesmo de outro benefício, tornando o processo moroso.

Embora represente obrigação única, o documento criado pela alteração da Lei de Custeio da Previdência Social, imposta pela Lei $n^{\circ}$ 9.528/97, apresenta o duplo intuito de agilizar a arrecadação e fiscalização das contribuições previdenciárias e do FGTS e de permitir ao segurado da Previdência Social que se beneficie de um atendimento mais ágil e justo, pois todos os dados necessários para a obtenção de seu benefício previdenciário, direito fundamental constitucionalmente garantido, estariam de posse do INSS.

Do exposto, resta claro que a essência do documento de informação ao FGTS e à Previdência Social é a de embasar, a partir dos dados informados compulsoriamente pelo contribuinte, os procedimentos de arrecadação e fiscalização das contribuições fundiárias e previdenciárias. Ainda, é a de alimentar o banco de dados do INSS com os salários de contribuição e vínculos dos trabalhadores, permitindo a concessão e cálculo dos benefícios previdenciários.

Vista a essência do documento, busquemos encontrar sua natureza jurídica. Preliminarmente, recordemos que o surgimento da GFIP decorre de disposição legal, de lei

\footnotetext{
${ }^{210}$ A Lei no 8870/94, nos artigos 3, 4 e 12, imputava obrigações à empresa, mas não direcionadas diretamente à fiscalização, com sentido de obrigação tributária acessória.

${ }^{211}$ São esses órgãos o INSS (Instituto Nacional do Seguro Social) e DRF (Departamento da Receita Federal), segundo o mesmo artigo 32 da Lei $n^{\circ} 8.212 / 91$.

${ }_{212}$ Cf. Regulamento da Previdência Social, aprovado pelo Decreto no 3.048/99, artigo 19.
} 
tributária, a Lei de Custeio da Previdência Social. Trata-se, claramente, de uma obrigação. ${ }^{213}$ Hugo de Brito Machado, tratando da obrigação tributária, assevera ser esta:

relação jurídica em virtude da qual o particular (sujeito passivo) tem o dever de prestar dinheiro ao Estado (sujeito ativo), ou de fazer, não fazer, ou tolerar algo no interesse da arrecadação ou da fiscalização dos tributos $[\ldots] .^{214}$

Esmiuçando sua definição, o doutrinador aponta a existência de duas espécies de obrigações tributárias, uma relativa à prestação pecuniária - obrigação de pagar - que é a principal, da qual decorre a dita acessória - a de fazer, não fazer ou tolerar - pois é instituída no interesse da arrecadação e fiscalização dos tributos. Define o Código Tributário Nacional (CTN), Lei n $\mathrm{n}^{\circ}$ 5.172/66, em seu artigo 113, que a obrigação tributária pode ser principal ou acessória, e nos parágrafos $2^{\circ}$ e $3^{\circ}$ do mencionado artigo, preceitua:

\begin{abstract}
Art. 113: ...
$\S 2^{\circ}$ A obrigação acessória decorrente da legislação tributária e tem por objeto as prestações, positivas ou negativas, nela previstas no interesse da arrecadação ou da fiscalização dos tributos.

$\S 3^{\circ}$ A obrigação acessória, pelo simples fato da sua inobservância, converte-se em obrigação principal relativamente à penalidade pecuniária.
\end{abstract}

Em essência, obrigação tributária acessória é o dever de fazer ou de suportar algo, previsto em lei tributária, que o contribuinte tem perante o Fisco para que esse, representando o Estado, possa melhor arrecadar ou fiscalizar os tributos. Em caso de inadimplemento, será o contribuinte compelido a uma penalidade pecuniária.

Ora, a GFIP se enquadra, à perfeição, na definição do códex tributário de obrigação acessória. É uma obrigação de fazer, portanto, prestação positiva, que atende ao interesse da fiscalização e arrecadação de tributos, pois, como se sabe, essa é a sorte das contribuições previdenciárias, cuja natureza tributária é indiscutível. Ademais, aos contribuintes resta preencher e enviar ao órgão arrecadador, na forma por ele estabelecida, uma guia ou declaração que contenha dados relacionados aos fatos geradores de contribuição previdenciária e outras informações de interesse do INSS. ${ }^{215}$

\footnotetext{
${ }^{213}$ Ver que a redação do inciso IV do artigo 32 da Lei n 8.212 , de 1991, preceitua que a empresa é obrigada a prestar informações ao INSS.

${ }^{214}$ MACHADO, Hugo de Brito. Curso de Direito Tributário. 20. ed. São Paulo: Malheiros Editores, 2002. p. 108.

${ }^{215}$ Excerto do inciso IV do artigo 32 da Lei 8.212/91.
} 
Do exposto, torna-se até despiciendo mencionar que o desiderato do documento acontece no interesse da arrecadação e fiscalização tributárias, pois, se não, a que serviriam dados relativos aos fatos geradores de um tributo? Por fim, é mister não olvidar que a obrigação é imposta por lei tributária, a Lei ${ }^{\circ}$ 8.212/91, denominada Lei de Custeio da Previdência Social.

Não obstante, não podemos esquecer que a GFIP também tem como função permitir o controle sobre a arrecadação e fiscalização do Fundo de Garantia por Tempo de Serviço. Assim, apoiados nos ensinamentos de Paulo de Barros Carvalho, podemos asseverar que a elaboração e entrega da GFIP é um dever instrumental ${ }^{216}$ imposto aos contribuintes que incorrerem em fatos geradores de contribuições previdenciárias e de fundo de garantia por tempo de serviço.

Porém, ao se perquirir a natureza jurídica de complexo documento previdenciário e fundiário somente esse viés pode ser observado? Decerto que não.

Vimos, alhures, que a GFIP contém importante viés social. Esse é representado pela obrigação imposta pela lei ao INSS para que ele utilize dos dados constantes da Guia de Recolhimento do Fundo de Garantia e Informações à Previdência Social para a concessão e cálculo dos benefícios previdenciários. Por esse motivo, não podemos nos restringir à natureza tributária, de obrigação acessória, da GFIP. Algo mais há. Algo que, por certo, não se enquadra meramente nos conceitos tributários do documento. Podemos até, com certo grau de certeza, afirmar que essa característica do documento suplanta - ou, no mínimo, complementa - a sua natureza tributária.

No capítulo 4, estudamos o documento em sua inteireza. Documento complexo, pois dispõe de dados de todos os trabalhadores que prestaram, naquela competência, serviços ao contribuinte obrigado a emitir a GFIP, além de outras informações de interesse da RFB, do INSS e do Conselho Curador do FGTS. Diante do tratamento dispensando ao assunto no capítulo anterior, antevê-se que a complexidade, a relevância e a utilização imediata do documento não têm o caráter tributário como o precípuo, pois os dados com importância tributária poderiam perfeitamente estar agrupados, totalizados por fato gerador específico e não especificado por trabalhador. ${ }^{217}$

\footnotetext{
${ }^{216}$ CARVALHO, Paulo de Barros. Direito tributário: linguagem e método. 1. ed. São Paulo: Noeses, 2008. p. 424.

${ }^{217}$ Crítica que se faz internamente na RFB é que a complexidade da GFIP e seu compartilhamento com outros órgãos estatais (Caixa e MTE) impedem uma análise tributária mais eficaz no tocante ao caráter de confissão de dívida do documento e, nesse sentido, de constituição de crédito tributário.
} 
Tal raciocínio, que não se mostra incorreto, leva-nos a antever que a chamada função social do documento de informações da Previdência Social não padece de irrelevância. Ao contrário, essa exsurge não só da disposição legal que o introduziu como verdadeira norma individual e concreta na teoria de Paulo de Barros Carvalho, ${ }^{218}$ mas também da própria finalidade das informações.

Assentemos, portanto, a característica social da GFIP. Porém, ainda nos resta verificar qual a natureza jurídica, nessa acepção, do documento em análise. Não se pode olvidar que, ainda, trata-se de uma obrigação legal e, como tal, sujeita a sanções, uma vez que não existe obrigação legal sem correspondente sanção que a garanta. ${ }^{219}$

A GFIP apresenta dupla natureza jurídica, em face de sua característica híbrida. De um lado, obrigação acessória tributária, pois contempla dados relativos aos fatos geradores, os quais permitem ao Fisco arrecadar e fiscalizar as contribuições previdenciárias devidas pelo contribuinte, obrigado ao preenchimento do documento. De outro lado, obrigação legal, em virtude dos dados sociais, laborais e previdenciários dos trabalhadores nela elencados, que permitem ao INSS a concessão e o cálculo dos benefícios desses trabalhadores. Analisemos, nos próximos tópicos, a finalidade tributária e social da GFIP.

\subsection{Finalidade tributária da GFIP}

Preceitua o artigo 32, inciso IV, da Lei ${ }^{\circ}$ 8.212/91, que a empresa deverá declarar na GFIP dados relacionados a fatos geradores, bases de cálculo e valores devidos de contribuição previdenciária. A Lei n ${ }^{\circ} 11.941$, de 2009 alterou a redação do parágrafo $2^{\circ}$ do mencionado inciso, deixando patente que a declaração dos fatos geradores em GFIP tem natureza de confissão de dívida, encerrando antiga polêmica administrativa e judicial sobre essa característica tão marcante de uma declaração tributária, pois, como sabido, tais declarações ensejam cobrança, no caso do inadimplemento do tributo ali confessado, em decorrência do caráter de autolançamento desses documentos. ${ }^{220}$

\footnotetext{
${ }^{218}$ Cf. CARVALHO, Paulo de Barros. Direito tributário: linguagem e método. 1. ed. São Paulo: Noeses, 2008. p. 141 e ss.

219 De Plácido e Silva, tratando de obrigações naturais, aquelas desprovidas de sanção legal, afirma que obrigação sem força exterior que a torne exequível é mero dever moral. Cf. SILVA, De Plácido e. Vocabulário Jurídico. 16. ed. Rio de Janeiro: Ed. Forense, 1999. p. 568.

${ }^{220}$ Cf. MACHADO, Hugo de Brito. Curso de Direito Tributário. 20. ed. São Paulo: Malheiros Editores. 2002. p. 150-153.
} 
Tal alteração da Lei de Custeio, no esteio da unificação do Fisco Federal, ${ }^{221}$ realça, mesmo que com cores tênues, a argumentação que se levanta no presente trabalho de que há primazia, perante o ordenamento positivo vigente, dos aspectos tributários da GFIP sobre os sociais. Porém, examinemos, por enquanto, as finalidades tributárias do documento de informações fundiárias e previdenciárias.

A empresa que incidir nos fatos geradores de contribuições previdenciárias, abaixo elencados, deve declará-los na GFIP da competência em que:

a) no mês em que for paga, devida ou creditada a remuneração, o que ocorrer primeiro, a segurado empregado ou a trabalhador avulso em decorrência da prestação de serviço;

b) no mês em que for paga ou creditada a remuneração, o que ocorrer primeiro, ao segurado contribuinte individual que lhe presta serviços;

c) no mês da emissão da nota fiscal ou da fatura de prestação de serviços por cooperativa de trabalho;

d) no mês da entrada da mercadoria no seu estabelecimento, quando transportada por cooperados intermediados por cooperativa de trabalho de transportadores autônomos;

e) no mês em que ocorrer a comercialização da produção rural, quando a empresa for subrogada na obrigação de recolhimento da contribuição;

f) no dia da realização de espetáculo desportivo gerador de receita, quando se tratar de associação desportiva que mantenha equipe de futebol profissional;

g) no mês em que auferir receita a título de patrocínio, de licenciamento de uso de marcas e símbolos, de publicidade, de propaganda e de transmissão de espetáculos desportivos, quando se tratar de associação desportiva que mantenha equipe de futebol profissional;

h) no mês do pagamento ou crédito da última parcela do décimo terceiro salário, observado o prazo máximo de 20 de dezembro, ou no caso de rescisão do contrato de trabalho a regra de recolhimento das verbas incidentes ali existentes;

i) no mês a que se referirem as férias, mesmo quando pagas antecipadamente na forma da legislação trabalhista.

Em relação ao segurado especial e ao produtor rural pessoa física, há obrigação de declarar no mês em que ocorrer a comercialização da sua produção rural. Quanto à obra de construção civil de responsabilidade de pessoa física, a declaração deverá ocorrer no mês em que ocorrer a prestação de serviços remunerados pelos segurados que edificam a obra.

\footnotetext{
${ }^{221}$ A Lei n ${ }^{\text {o }}$ 11.457/07 criou a Receita Federal do Brasil como resultado da fusão das Secretarias da Receita Federal e da Receita Previdenciária, unindo o Fisco Federal na chamada Super Receita.
} 
Não se deve esquecer que se considera creditada a remuneração na competência em que a empresa contratante for obrigada a reconhecer contabilmente a despesa ou o dispêndio ou, no caso de equiparado ou empresa legalmente dispensada da escrituração contábil regular, na data da emissão do documento comprobatório da prestação de serviço. Para os órgãos do Poder Público, considera-se creditada a remuneração na competência da liquidação do empenho, entendendo-se como tal o momento do reconhecimento da despesa.

Devem ainda constar da GFIP, como vimos, as informações de interesse do INSS e da RFB, e, por óbvio, os casos de compensação e de substituição tributária são duas dessas informações. Assim, se a empresa for prestadora de serviço em cessão de mão-de-obra, deverá sofrer retenção de $11 \%$ do valor da nota fiscal ou fatura da prestação de serviço realizada e compensará o valor descontado das contribuições incidentes sobre a sua folha de pagamento. Essa compensação deverá ser apresentada na GFIP.

$\mathrm{Na}$ apertada síntese apresentada, podemos verificar a multiplicidade de fatos geradores de contribuições previdenciárias e suas especificidades. Para ficarmos somente com um exemplo, quantos profissionais atuantes no Direito Tributário recordariam que a compra de pontaletes de madeira reflorestada por uma obra de construção civil pode ser fato gerador de contribuição previdenciária e deve, portanto, constar na GFIP do responsável por essa obra?

Ao lado do exemplo apresentado, singelo e específico, podemos mencionar o mais complexo e comum, que seria o de uma empresa com quatro ou cinco mil trabalhadores, com os mais variados vínculos, e eventuais contratações de pessoas jurídicas prestadoras de serviço e de cooperativas de trabalho. Não é necessário nenhum esforço para se imaginar a quantidade de informações de fatos geradores de contribuição previdenciária, segurado por segurado, que existirão nesse documento.

Como poderia o Fisco, em um país de dimensões continentais como o Brasil, com a complexidade de sua economia e a pluralidade de empresas de todos os portes e localizadas em tantas regiões, realizar um trabalho eficaz no interesse da arrecadação e fiscalização das contribuições sem um documento de informações como a GFIP? Resta claro, portanto, sua finalidade tributária, no sentido da própria definição de obrigação acessória, obrigação do contribuinte de fazer algo no interesse da arrecadação ou fiscalização do tributo. 
Atualmente, é assente o caráter tributário do $\mathrm{FGTS}^{222}$ quanto à contribuição mensal da empresa. ${ }^{223}$ No tocante ao trabalhador, a doutrina se divide em ser o FGTS salário diferido ou substitutivo de indenização. ${ }^{224}$

Vimos a importância das informações tributárias constantes da GFIP para a arrecadação e fiscalização das contribuições previdenciárias. O mesmo pode-se dizer para o FGTS, até porque o caráter de obrigação acessória quanto ao tributo FGTS revela-se pela existência do valor do tributo devido no documento de informações das bases de cálculo do FGTS, e dos casos de não incidência, vinculados ao contrato de trabalho. Esse entendimento é corroborado pela legislação de regência do FGTS. A Instrução Normativa $n^{\circ}$ 99, de 23 de agosto de 2012, da Secretaria da Inspeção do Trabalho do Ministério do Trabalho, normatizando as Leis $\mathrm{n}^{\circ} \mathrm{s}$. 8.036/90, 8.844/94 e a Lei Complementar $\mathrm{n}^{\mathrm{o}} 110$, de 2001, trata da fiscalização do FGTS e remete à GFIP como documento que suporta a declaração dos dados.

\subsection{Finalidade social da GFIP}

A Constituição da República Federativa do Brasil, em seu artigo $6^{\circ}$, na redação dada pela Emenda Constitucional n ${ }^{\circ} 26$, de 14 de fevereiro de 2000, elenca os direitos sociais que o Estado Brasileiro deve assegurar, dentre os quais, a previdência social.

A Lei de Benefícios, Lei $\mathrm{n}^{\circ}$ 8.213, de 1991, estipula em seu artigo $1^{\text {o }}$ que a Previdência Social, mediante contribuição, tem como finalidade assegurar aos seus beneficiários meios indispensáveis de manutenção por motivo de incapacidade, desemprego involuntário, idade avançada, tempo de serviço, encargos familiares e prisão ou morte daqueles de quem dependiam economicamente. Analisemos alguns aspectos do comando legal.

O beneficiário, chamado pela lei de segurado ou dependente, ${ }^{225}$ deve contribuir para o sistema para ter direito aos benefícios assegurados na lei. Importante ressaltar que essa contribuição é compulsória toda vez que a pessoa física trabalha mediante remuneração, tornando-se, nos termos da lei, segurado obrigatório da Previdência Social.

\footnotetext{
${ }^{222}$ Cf. MARTINS, Sergio Pinto. Direito do Trabalho. 23. ed. São Paulo: Atlas, 2007. p.447.

${ }^{223}$ Não se pode olvidar o entendimento do STJ, exarado pela Súmula 353, ressalvando que as disposições do CTN não se aplicam ao FGTS. Ressalte-se que tal determinação decorre de decisões relacionadas à responsabilização solidária de sócios e administradores nas ações de cobrança do FGTS.

${ }^{224}$ Cf. BARROS, Alice Monteiro de. Curso de Direito do Trabalho. 2. ed. São Paulo: LTr, 2006. p. 969.

${ }^{225}$ Art. 10 da Lei ${ }^{\circ}$ 8.213/91.
} 
Somente na ausência do trabalho ou na realização de trabalho não remunerado a contribuição é facultativa, opção pessoal, que leva o cidadão a ser enquadrado como segurado facultativo. Disso decorre o caráter contributivo do sistema previdenciário pátrio.

O segurado facultativo e o contribuinte individual - antigamente denominado autônomo - que não trabalham para uma empresa ou a ela equiparada (obrigadas à entrega da GFIP), o empregado doméstico e o segurado especial, quando da necessidade de algum benefício, devem demonstrar seu vínculo através da comprovação dos recolhimentos tempestivos ao sistema previdenciário. ${ }^{226}$ Já os segurados obrigatórios que mantiverem vínculo de trabalho com empresa ou pessoa equiparada são dispensados dessa comprovação de recolhimento, pois os tomadores de trabalho têm obrigação de reter a contribuição previdenciária, conforme a Lei de Custeio da Previdência, Lei n ${ }^{\circ}$ 8.212/91. ${ }^{227}$

Tal distinção quanto à comprovação de recolhimento e, por força de lei, de vínculo previdenciário, é fulcral quando do direito à percepção de algum benefício. A Lei no 8.213, de 1991, preceitua:

Art. 29-A. O INSS utilizará as informações constantes no Cadastro Nacional de Informações Sociais - CNIS sobre os vínculos e as remunerações dos segurados, para fins de cálculo do salário de benefício, comprovação de filiação ao Regime Geral de Previdência Social, tempo de contribuiçãa e relação de emprego. (negritamos)

Essa redação do artigo 29-A da Lei de Benefícios foi aprimorada pela Lei Complementar $n^{\circ} 128$, de 2008, visto que, na redação dada pela Lei $n^{\circ} 10.403$, de 2002, constava que o INSS utilizaria os dados do CNIS para o cálculo dos benefícios concedidos. Mudança sutil, mas relevante. Atualmente, a autarquia previdenciária deve utilizar as informações constantes do cadastro não só para o cálculo do salário de benefício, como também para comprovação de filiação, tempo de contribuição e relação de emprego.

Fica patente, desse modo, a importância social do CNIS. De seus dados serão obtidas as informações imprescindíveis para a concessão de um benefício previdenciário, que, para muitos, é a expressão do Estado de Bem-Estar Social. Veremos, com o devido vagar, no capítulo 6 os meios pelos quais o CNIS é abastecido com as informações do trabalhador. Por ora, aceitemos a informação de que a GFIP é o principal mecanismo do qual o CNIS dispõe.

\footnotetext{
${ }^{226}$ Art.27, II combinado com art. 34, III, ambos da Lei no 8.213/91.

${ }^{227}$ Art. 30, inciso I, 'a' e 'b', da Lei n' 8.212, de 1991.
} 
A Guia de Informações ao FGTS e à Previdência Social tem o nítido caráter que ostenta no próprio nome, o social. Conforme exposto, as informações cadastrais do trabalhador, seu vínculo de trabalho, sua condição laboral, sua remuneração e eventuais benefícios previdenciários percebidos constam da Guia de Informações e são mensalmente renovados e enviados. A declaração emanada da fonte fruidora do trabalho humano aos órgãos públicos encarregados de implementar os direitos sociais, no caso Caixa Econômica Federal e Instituto Nacional do Seguro Social, permite que aqueles se desvencilhem de seu encargo com rapidez e com a certeza do valor da prestação devida. Vejamos o porquê dessa afirmação.

Segundo o artigo 201 da Constituição Federal, a Previdência Social tem caráter contributivo e filiação obrigatória, ou seja, a pessoa física que trabalha mediante remuneração é segurado obrigatório da Previdência Social. Como consequência do comando constitucional, temos que a filiação decorre do trabalho remunerado, uma vez que compulsória. Assim, ocorrendo o fato trabalho remunerado no mundo fenomênico, temos, por força de lei, ${ }^{228}$ a filiação da pessoa física, conceito que, para Pereira de Castro e Lazzari remete ao "vínculo jurídico que se estabelece entre pessoas que contribuem como segurados para a Previdência Social e esta, vínculo este do qual decorrem direitos e deveres." 229

Posto que a filiação decorre automaticamente do exercício da atividade remunerada, a autarquia previdenciária deve ser cientificada da situação, uma vez que, como visto, surgirão direitos e obrigações entre a autarquia e o trabalhador. Surge, pois, a necessidade da inscrição do segurado. Essa, segundo Zambitte, é "ato meramente formal, pelo qual o segurado fornece dados necessários para sua identificação à autarquia previdenciária." 230

Tratando do tema, a Instrução Normativa INSS/PRES n ${ }^{\circ}$ 45, de 06/08/10, prescreve, no artigo 39, que "filiado é aquele que se relaciona com a Previdência Social na qualidade de segurado obrigatório ou facultativo, mediante contribuição”, e, ainda, no $1^{\circ}$, que a inscrição do filiado será formalizada:

\footnotetext{
${ }^{228}$ Lei no 8.213/91, artigo 17, determina que a inscrição no RGPS será realizada nos termos do Regulamento da Previdência Social, RPS, que dispõe sobre o tema em seu artigo 18.

${ }^{229}$ CASTRO, Carlos Alberto Pereira de; LAZZARI, João Batista. Manual de Direito Previdenciário. 8. ed. Florianópolis: Conceito Editorial, 2007. p.177

${ }^{230}$ IBRAHIM, Fábio Zambitte. Curso de Direito Previdenciário. 16ª ed. Niterói: Ed. Impetus, 2011. p. 175.
} 
I - para o empregado e trabalhador avulso: pelo preenchimento, de responsabilidade do empregador, dos documentos que os habilitem ao exercício da atividade, formalizado pelo contrato de trabalho no caso de empregado, observado o disposto no art. 42, e pelo cadastramento e registro no sindicato ou órgão gestor de mão-de-obra, no caso de trabalhador avulso, com inclusão automática no CNIS proveniente da declaração prestada em GFIP. (grifo nosso)

Em síntese, o trabalho remunerado da pessoa física obriga a filiação dela à Previdência Social. A filiação, desencadeadora de obrigações - pagar a contribuição social - e direitos previdenciários - ser beneficiário do seguro social -, materializa-se pela inscrição junto ao INSS. ${ }^{231}$

Chegamos à primeira exteriorização da finalidade social da Guia de Informação ao FGTS e Previdência Social: implementar a inscrição do maior contingente de segurados, aqueles que laboram para a empresa ou equiparado, ${ }^{232}$ os obrigados à entrega da GFIP. ${ }^{233}$ É, portanto, pela GFIP que o trabalhador que pessoalmente prestou serviços à pessoa jurídica, ou a ela equiparada, sob qualquer vínculo, será inscrito no INSS e, a partir de então, estará inserido no sistema de seguro social brasileiro.

Não se esgota aqui a finalidade social da GFIP. Se o trabalhador necessitar de amparo do sistema previdenciário, ele deverá, para obter a proteção almejada, além de estar inscrito no sistema, ter cumprido, se for o caso, o período de carência, ou seja, comprovar um tempo mínimo de contribuição. Fazendo jus ao benefício, o trabalhador terá o valor da renda mensal de benefício calculado em função do valor das contribuições comprovadamente recolhidas.

Tal comprovação torna-se despicienda quando os dados do trabalhador, afetos ao tempo de contribuição e salário de contribuição, constam do CNIS, ou seja, quando o Cadastro Nacional de Informações Sociais foi corretamente alimentado pela GFIP, com dados mensais relativos à remuneração percebida pelo trabalhador decorrente de sua atividade laboral. Eis, então, nova finalidade social apontada, a manutenção do CNIS.

\footnotetext{
${ }^{231}$ Segundo Zambitte, "na prática a inscrição acaba por assumir maior relevância que a filiação, pois esta é, em geral, desconhecida da autarquia previdenciária, enquanto a inscrição fica registrada em seus cadastros." Cf. IBRAHIM, Fábio Zambitte. Curso de direito previdenciário. 16 ed. Niterói: Ed. Impetus, 2011. p. 176.

${ }^{232}$ Regulamento da Previdência Social (RPS) aprovado pelo Decreto n ${ }^{\circ} 3.048$, de 1999, artigo 12, § u, determina que se equipara à empresa o contribuinte individual que remunera pessoa física pelo trabalho, $\mathrm{o}$ operador portuário e órgão gestor de mão-de-obra, a cooperativa, a associação ou entidade de qualquer natureza, a missão diplomática e repartição consular, o proprietário, incorporador ou dono de obra.

${ }^{233}$ Lei $\mathrm{n}^{\circ}$ 8.212, de 1991, artigo 32, inciso IV.
} 
Vejamos como o INSS observa a questão. O artigo 47 da Instrução Normativa INSS/PRES n $45 / 10$, esclarece:

Art. 47. A partir de 31 de dezembro de 2008 , data da publicação do Decreto $\mathrm{n}^{\circ} 6.722$, de 30 de dezembro de 2008, os dados constantes do CNIS relativos a vínculos, remunerações e contribuições valem, a qualquer tempo, como prova de filiação à Previdência Social, tempo de contribuição e salários-de-contribuição. (grifo nosso)

Tal comando normativo visa, como visto alhures, implementar a inversão do ônus da prova, determinado pela Lei Complementar $n^{\circ} 128$, de 2008. Somente no caso da não concordância do segurado com os dados constantes do sistema é que a ele caberá a comprovação de suas alegações, por ser fato modificativo de seu direito. Essa previsão consta do artigo 48 da Instrução Normativa INSS/PRES nº 45/10:

Art. 48. O segurado poderá solicitar, a qualquer momento, a inclusão, exclusão, validação ou retificação das informações constantes do CNIS, com a apresentação de documentos comprobatórios dos dados pendentes de validação ou divergentes, independentemente de requerimento de benefício [...] (grifo nosso)

Por isso, recorda-nos Fábio Zambitte Ibrahim, ${ }^{234}$ foi criada a GFIP, “com o objetivo principal de abastecer o CNIS (Cadastro Nacional de Informações Sociais), com as informações relativas aos segurados da previdência social." Não podemos esquecer que a renda mensal dos benefícios previdenciários, com exceção do salário-família, do saláriomaternidade e da pensão por morte, ${ }^{235}$ é calculada em função do salário-de-benefício, que, em regra, é obtido pela média aritmética corrigida dos $80 \%$ maiores salários-decontribuição. É justamente o salário-de-contribuição um dos dados do trabalhador de maior relevância constante da GFIP, exatamente por ser de interesse duplo, ou seja, tributário, pois é base de cálculo da contribuição do segurado obrigatório, e social, pois dele decorre, como apontado, o cálculo do salário-de-benefício.

Esclarece-se, assim, a finalidade social da GFIP como documento revestido do objetivo de fornecer os dados necessários ao povoamento do CNIS, a qual garante ao

\footnotetext{
${ }^{234}$ IBRAHIM, Fábio Zambitte. Curso de direito previdenciário. 16 $6^{\mathrm{a}}$ ed. Niterói: Ed. Impetus, 2011. p. 372.

${ }^{235}$ O salário-família tem valor fixo definido por Regulamento, conforme o art.83 do RPS. O saláriomaternidade da empregada é igual ao seu salário mensal; da contribuinte individual ou facultativa igual à média do seu salário-de-contribuição dos últimos doze meses; da segurada especial um salário-mínimo; e para a empregada doméstica o último salário-de-contribuição, segundo os artigos 100 e 101 do RPS.
} 
trabalhador brasileiro e à sua família a rápida intervenção da previdência social nos casos permanentes ou temporários de incapacidade de provimento do sustento pelo trabalho. Vejamos a seguir se há função social da GFIP do ponto de vista do Fundo de Garantia por Tempo de Serviço.

A Constituição de 1988, no Capítulo II, o qual versa sobre os Direitos Sociais, preceitua:

Art. $7^{\circ}$ São direitos dos trabalhadores urbanos e rurais, além de outros que visem à melhoria de sua condição social:

I - relação de emprego protegida contra despedida arbitrária ou sem justa causa, nos termos de lei complementar, que preverá indenização compensatória, dentre outros direitos [...];

III - fundo de garantia do tempo de serviço [...]. (grifo nosso)

O Ato das Disposições Constitucionais Transitórias (ADCT), em seu artigo 10 inciso I, determinou que, até que sobrevenha a lei complementar exigida no artigo $7^{\circ}$, inciso I, a indenização compensatória se consubstanciaria em $40 \%$ sobre o total dos depósitos realizados na conta vinculada do FGTS. Despontam, portanto, dos comandos constitucionais mencionados duas tutelas sociais baseadas no fundo de garantia do tempo de serviço. O próprio fundo, representado por depósitos mensais calculados sobre a remuneração do trabalhador e realizado às expensas do empregador, é encarado como salário diferido. ${ }^{236}$ Outros veem no FGTS uma poupança feita pelo empregador em proveito do obreiro, para ser utilizada em casos específicos previstos em lei, dentre os quais a dispensa sem justa causa. Surge, assim, um nítido viés social.

Em segundo lugar, como tutela social, há a indenização pelo rompimento do contrato de trabalho sem justa causa, prefixada em $40 \%$ do valor total depositado na conta vinculada do Fundo de Garantia do Tempo de Serviço do trabalhador dispensado. Para alguns, ${ }^{237}$ exprime a observância, pelo ordenamento pátrio, da implementação da garantia leia-se indenização apropriada -, contra a dispensa imotivada, em consonância com a Convenção $n^{\circ} 157$ da Organização Internacional do Trabalho, ratificada e posteriormente

\footnotetext{
${ }^{236}$ Citamos, anteriormente, entendimento doutrinário, com o qual concordamos, sobre a duplicidade da natureza jurídica do FGTS.

${ }^{237}$ Cf. NASCIMENTO, Amauri Mascaro. Dispensas Individuais. Reconstrução do Direito do Trabalho. In: ACADEMIA NACIONAL DE DIREITO DO TRABALHO, 2010, São Paulo. Anais... São Paulo: LTr, 2010. Em sentido contrário, conferir: MAIOR, Jorge Luiz Souto. Convenção 158 da OIT. Dispositivo que veda a dispensa arbitrária é auto-aplicável. Disponível em: <http://jus.uol.com.br/revista/texto/5820/convencao-158da-oit>. Acesso em: 25 jun. 2011.
} 
denunciada pelo Brasil. ${ }^{238}$ As duas proteções constitucionais são implementadas pela GFIP.

Os depósitos mensais feitos na conta do trabalhador são individualizados pela GFIP. A empresa, ou a pessoa equiparada, como visto acima, informa, na GFIP, todos dos dados dos seus empregados que tiveram direito ao depósito mensal fundiário, inclusive a base de cálculo dos depósitos. O recolhimento do montante devido pela empresa se dá pela GRF (Guia de Recolhimento do FGTS) gerada pelo Sistema Empresa de Recolhimento do FGTS e Informações à Previdência Social (SEFIP).

A Instrução Normativa MTE $n^{\circ}$ 99, de 13 de agosto de 2012, determina, no sentido exposto no artigo 35, que "a individualização do valor devido ou recolhido de FGTS na conta vinculada do empregado consiste obrigação do empregador.” Já o recolhimento do FGTS por conta da rescisão do contrato de trabalho sem justa causa deverá ser realizado por meio da Guia de Recolhimento Rescisório do FGTS (GRRF). Novamente, temos a GFIP, por meio das informações dos trabalhadores que concentra, como um instrumento que implementa direitos sociais representados pelo Fundo de Garantia do Tempo de Serviço (FGTS), tanto no tocante aos depósitos mensais, quanto à indenização por dispensa sem justa causa, calculada sobre o valor total dos depósitos na conta vinculada do FGTS do trabalhador.

\subsection{Sanções previstas}

Normas jurídicas diferem basicamente de normas morais quanto ao descumprimento. As morais, se descumpridas, geram um desconforto interno, de foro íntimo, causando no agente arrependimento, censura pessoal, por vezes social, mas nunca reprimendas de ordem pública aplicadas por autoridades constituídas. Já as normas jurídicas têm em seu comando o caráter de licitude embutido; é dizer, o agir em consonância com o direito objetivo é tido como lícito.

O comportamento ilícito decorre de ação ou omissão não prevista no ordenamento jurídico. Esse tipo de conduta, diferentemente de uma contrária a moral, gera consequência externa para o agente, denominada sanção. Nos dizeres de Hugo de Brito Machado:

\footnotetext{
${ }^{238}$ Em 1972 o Brasil ratificou a Convenção 158, promulgando-a, pelo Decreto $\mathrm{n}^{\circ}$ 1.855, publicado no DO em 11.04.1996. Em 20 de dezembro, pelo Decreto ${ }^{\circ}$ 2100, denunciou-a. Há discussão no STF sobre a validade da denúncia, uma vez que foi realizada por ato do Chefe do Executivo, e não por ato do Congresso Nacional.
} 
Sanção é o meio de que se vale a ordem jurídica para desestimular o comportamento ilícito. Pode limitar-se a compelir o responsável pela inobservância da norma ao cumprimento do seu dever, e pode consistir num castigo, numa penalidade a este cominada. ${ }^{239}$

Nesse mesmo sentido, complementa Paulo de Barros Carvalho:

O ordenamento jurídico, como forma de torna possível a coexistência do homem em comunidade, garante, efetivamente, o cumprimento de suas ordens, ainda que, para tanto, seja necessária a adoção de medidas punitivas que afetem a propriedade ou a própria liberdade das pessoas. Daí por que, ao criar uma prestação jurídica, concomitantemente o legislador enlaça uma providência sancionatória ao não cumprimento do referido dever. ${ }^{240}$

A providência sancionatória vem instituída por lei, norma geral e abstrata, na lição de Paulo de Barros, que contém os mesmos elementos da regra matriz de incidência tributária, ${ }^{241}$ ou seja, em seu antecedente a descrição hipotética do fato ilícito ou infração e no consequente os elementos que compõe o nexo sancionatório. Continua Barros Carvalho:

[...] o antecedente da norma sancionatória, que tem seu caráter material uma conduta infringente de dever jurídico -, um critério espacial - uma conduta há de ocorrer em certo lugar - e um critério temporal - o instante em que se considera acontecido o ilícito. Na consequência, depararemos com um critério pessoal - o sujeito ativo será aquele investido do direito subjetivo de exigir a multa e o sujeito passivo o que deve pagá-la - e um critério quantitativo - a base de cálculo da sanção pecuniária e a percentagem sobre ela aplicada. ${ }^{242}$

\subsubsection{Sanções afetas às Contribuições Previdenciárias}

\footnotetext{
${ }^{239}$ MACHADO, Hugo de Brito. Curso de Direito Tributário. 20. ed. São Paulo: Malheiros Editores, 2002. p.417.

${ }^{240}$ CARVAlHO, Paulo de Barros. Curso de Direito Tributário. 14ª ed. São Paulo: Ed. Saraiva, 2002. p. 498

${ }^{241}$ Regra Matriz de Incidência Tributária, na lição Paulo de Barros Carvalho, é a decomposição semântica de uma norma de incidência tributária, sendo elementos do antecedente a hipótese tributária, ou seja, critério material (verbo e seu complemento); critério espacial (território), critério temporal (condicionante do tempo). No consequente da norma, encontraremos o critério pessoal (sujeito ativo e passivo), e o critério quantitativo (base de cálculo e alíquota). Cf. CARVALHO, Paulo de Barros. Curso de Direito Tributário. 14 ${ }^{a}$ ed. São Paulo: Ed. Saraiva, 2002. p. 343 e 501.

${ }^{242}$ CARVAlHO, Paulo de Barros. Curso de Direito Tributário. 14 a ed. São Paulo: Ed. Saraiva, 2002. p. 498.
} 
Vimos, ao longo do presente capítulo, a dupla natureza jurídica da GFIP. Natureza jurídica de obrigação acessória tributária e natureza jurídica de obrigação legal, em face de sua característica de documento social previsto em lei.

Esta duplicidade de essência jurídica, tributária e civil, necessariamente, exige uma preocupação, também de dupla natureza, quanto ao descumprimento da obrigação. A omissão ou incorreção do documento de informações acarreta distintas consequências, tributárias e sociais, igualmente importantes. Essas derivam da finalidade dos dados de permitirem ao Fisco a constatação do lançamento tributário das contribuições sociais e fundiárias, aliada à possibilidade de verificação dessa correção desse lançamento e do objetivo de povoar o CNIS e o FGTS com os dados laborais e previdenciários do segurado/contribuinte que trabalhou para a empresa, ou equiparado, a que se obriga a prestação de informações via GFIP. Dito por outro modo: a sanção pelo descumprimento da obrigação deve ser efetivada de modo a proteger tanto os interesses tributários quanto os interesses sociais albergados na GFIP.

É justamente nessa visão de dúplice finalidade ofendida ocasionada pelo descumprimento total ou parcial da obrigação que surge a incoerência do sistema legal hoje posto por força da Lei $\mathrm{n}^{\circ}$ 11.941, de 2009. Vejamos. No caso de eventual descumprimento, pelo obrigado, do dever de prestar as informações pela GFIP, teremos uma sanção. Tendo essa obrigação natureza tributária, sendo classificável como obrigação acessória, podemos inferir que a pena também terá natureza tributária.

Havendo descumprimento total ou parcial do dever de informação, ou seja, deixando o contribuinte de entregar a GFIP no prazo legal estipulado, ${ }^{243}$ ou sendo ela entregue com erro ou omissões, a sanção prevista na Lei de Custeio da Previdência Social, Lei $n^{\circ} 8.212$, de 1991, em seu artigo 32-A, incluído pela Lei no 11.941, de 2009, está assim estipulada:

Art. 32-A. O contribuinte que deixar de apresentar a declaração de que trata o inciso IV do caput do art. 32 desta Lei no prazo fixado ou que a apresentar com incorreções ou omissões será intimado a apresentá-la ou a prestar esclarecimentos e sujeitar-se-á às seguintes multas:

I - de $\mathrm{R} \$ 20,00$ (vinte reais) para cada grupo de 10 (dez) informações incorretas ou omitidas; e

II - de $2 \%$ (dois por cento) ao mês-calendário ou fração, incidentes sobre o montante das contribuições informadas, ainda que integralmente pagas, no caso de falta de entrega da declaração ou entrega após o prazo,

${ }^{243}$ Até dia 07 do mês seguinte ao qual se referirem as informações, segundo o Regulamento da Previdência Social (RPS) aprovado pelo Decreto $n^{\circ} 3.048$, de 1999, art. 225, $\S 2^{\circ}$. 
limitada a $20 \%$ (vinte por cento), observado o disposto no $\S 3^{\underline{0}}$ deste artigo.

$\S 1^{\circ}$ Para efeito de aplicação da multa prevista no inciso II do caput deste artigo, será considerado como termo inicial o dia seguinte ao término do prazo fixado para entrega da declaração e como termo final a data da efetiva entrega ou, no caso de não apresentação, a data da lavratura do auto de infração ou da notificação de lançamento.

$\S 2^{0}$ Observado o disposto no $\S 3^{0}$ deste artigo, as multas serão reduzidas:

I - à metade, quando a declaração for apresentada após o prazo, mas antes de qualquer procedimento de ofício; ou

II - a 75\% (setenta e cinco por cento), se houver apresentação da declaração no prazo fixado em intimação.

$\S 3^{0}$ A multa mínima a ser aplicada será de:

I - R \$ 200,00 (duzentos reais), tratando-se de omissão de declaração sem ocorrência de fatos geradores de contribuição previdenciária; e

II - R \$ 500,00 (quinhentos reais), nos demais casos. (grifo nosso)

Assinalamos, anteriormente, o caráter de obrigação tributária acessória da GFIP. Nesse sentido, a sanção imposta pela Lei de Custeio, ou seja, multa pecuniária, segundo o desiderato do Código Tributário Nacional, ${ }^{244}$ o qual determina que a obrigação acessória inadimplida se transforma em principal quanto à multa pecuniária.

Não obstante o diminuto valor da pena, por certo em nada desencorajador da conduta omissiva, andou bem o legislador ao prever a redução da multa no caso de correção da informação prestada, ou da entrega extemporânea, em face de necessidade de povoamento do CNIS. É o que verificamos no parágrafo segundo, acima transcrito em negrito, do artigo 32-A mencionado.

De resto, vinte reais, exatos vinte reais por grupo de 10 informações incorretas ou omitidas, atestam que cada campo da GFIP, ${ }^{245}$ usualmente de vital importância tributária e social, ${ }^{246}$ preenchido com erros ou ausência de dados, é punido com multa de R \$2,00. Ainda bem que é reduzível, o valor da multa, se houver a entrega retificadora ainda que tardia, pois ao menos se corrige o CNIS.

Não esqueçamos os valores mínimos de $\mathrm{R}$ \$ 200,00 ou $\mathrm{R}$ \$ 500,00, este quando há omissão de fatos geradores de contribuição social, patamares intransponíveis mesmo quando da retificação ou entrega fora do prazo legal.

É senso comum a severidade das penas impostas pela Receita Federal do Brasil ao contribuinte inadimplente, seja ele um mero devedor, seja um sonegador. Apenas por um

\footnotetext{
${ }^{244}$ Decreto $\mathrm{n}^{\mathrm{o}} 5.172$, de 1966 , artigo $113, \S 3^{\circ}$.

${ }^{245}$ Sobre a estrutura da GFIP, ver capitulo 4.

${ }^{246}$ A importância social perdoa a repetição: os campos da GFIP contêm informações que se referem à vida laboral do trabalhador, as quais repercutem em seus direitos previdenciários.
} 
exemplo se confirma a afirmação: a simples entrega em atraso da Declaração de Ajuste Anual do Imposto sobre a Renda da Pessoa Física enseja multa de 1\% ao mês-calendário ou fração de atraso, calculada sobre o total do imposto devido apurado na declaração, ainda que integralmente pago, sendo que o valor mínimo é de $\mathrm{R} \$ 165,74$ e o valor máximo é de $20 \%$ do imposto de renda devido. Nesse sentido, cabe uma indagação: como uma declaração que confessa um tributo de expressiva monta ${ }^{247}$ - toda a contribuição social devida e retida pela pessoa jurídica - pode ter uma sanção de tão diminuto valor?

A resposta consta do artigo 35-A da Lei $n^{\circ} 8.212$, de 1991, incluído pela Lei $n^{\circ}$ 11.941, de 2009, que determina que nos casos de lançamento de ofício das contribuições sociais aplica-se o disposto no artigo 44 da Lei $n^{\circ} 9.430$, de 1996 , com a redação da Lei ${ }^{\circ}$ 11.488, de 2007:

\begin{abstract}
Art. 44. Nos casos de lançamento de ofício, serão aplicadas as seguintes multas:

I - de $75 \%$ (setenta e cinco por cento) sobre a totalidade ou diferença de imposto ou contribuição nos casos de falta de pagamento ou recolhimento, de falta de declaração e nos de declaração inexata [...]; $\S 1^{0} \mathrm{O}$ percentual de multa de que trata $\mathrm{o}$ inciso I do caput deste artigo será duplicado nos casos previstos nos arts. 71, 72 e 73 da Lei no $\mathbf{4 . 5 0 2}^{\mathbf{2 4 8}}$, de 30 de novembro de 1964 , independentemente de outras penalidades administrativas ou criminais cabíveis.

$\S 2^{\underline{o}}$ Os percentuais de multa a que se referem o inciso I do caput e o $\S 1^{\underline{o}}$ deste artigo serão aumentados de metade, nos casos de não atendimento pelo sujeito passivo, no prazo marcado, de intimação [...]" (grifo nosso)
\end{abstract}

Evidencia-se de plano o intuito do Fisco: punir o descumprimento da obrigação tributária não está na sanção pelo inadimplemento da obrigação acessória tributária. Essa pena desencorajadora, pois extremamente onerosa, surge na constituição de ofício da obrigação principal, denotando o caráter de confissão de dívida que a Lei de Custeio da Previdência passou a valorizar na GFIP, após a alteração de redação que sofreu com o advento da Lei $\mathrm{n}^{\circ}$ 11.941, de 2009. É indiscutível que há uma prevalência de objetivo tutelado.

\footnotetext{
247 Arrecadação com as contribuições sociais previdenciárias superam a dos demais tributos no âmbito federal. Em 2011, no Brasil, foram arrecadados R\$ 271,59 bilhões em receitas das contribuições previdenciárias contra $\mathrm{R} \$ 249,82$ bilhões de imposto sobre a renda das pessoas físicas e jurídicas. Cf. Revista da Seguridade Social e Tributação, ano XXII, no 110, janeiro/março 2012, p. 29. Publicação da ANFIP (Associação Nacional dos Auditores Fiscais da Receita Federal do Brasil).

248 O artigo 71 da Lei n ${ }^{\circ}$ 4.502/64 define sonegação tributária (ação ou omissão dolosa tendente a impedir ou retardar, total ou parcialmente, o conhecimento da ocorrência do fato gerador); o artigo 72 fraude (ação ou omissão dolosa tendente a impedir ou retardar, total ou parcialmente, a ocorrência do fato gerador); e artigo 73 conluio (ajuste doloso entre duas ou mais pessoas, visando a sonegação ou fraude).
} 
Ao punir o crédito tributário não informado pelo documento legalmente criado com tal desiderato, com multa de $75 \%$ ou $150 \%$, fica patente a defesa do instrumento de confissão de dívida criado pelo Estado para proteger os seus créditos tributários. Entender o porquê dessa sanção não ocorrer pelo inadimplemento da obrigação acessória, que é penalizada por valores infinitamente menores, e sim quando da constituição do crédito tributário não confessado, é ponto fulcral do presente trabalho.

Uma obrigação acessória tem finalidade explícita de permitir à Administração Tributária o cumprimento de sua função institucional. Tal entendimento decorre da própria definição do Código Tributário Nacional, que, em seu artigo $113, \S 2^{\circ}$, ao dispor sobre essa obrigação tributária, afirma que ela será decorrente da legislação pertinente e terá por objeto as prestações, positivas ou negativas, no interesse da arrecadação ou da fiscalização dos tributos.

Ora, quando da constituição do crédito tributário, o Auditor Fiscal da Receita Federal $^{249}$ tem ou deve ter acesso ao documento de confissão do crédito e verifica que nele há incorreções ou omissões que acarretem o lançamento de ofício. Não há, portanto, nenhum óbice, senão a vontade do legislador, para que a sanção desestimuladora do preenchimento incorreto, ou no mínimo descuidado, da GFIP não se dê na autuação do documento informativo em si. Isto é, poderia perfeitamente ser aplicada uma pena, ocasionada pelas informações incorretas ou omitidas da guia, de tal monta que dissuadisse o contribuinte de negligenciar o preenchimento do documento de informações ao FGTS e Previdência Social. E era assim.

Até 2 de dezembro de 2008, ${ }^{250}$ o Auditor Fiscal da Receita Federal do Brasil, ao constatar omissões ou incorreções no preenchimento da GFIP, independentemente do efetivo recolhimento da contribuição devida, autuava a empresa, ou obrigado, à entrega da GFIP, dependendo do caso, em até $100 \%$ do valor do tributo devido. É evidente que tal autuação não obstava à constituição de eventual crédito das contribuições devidas, mas, ao contribuinte, restava demonstrada a importância capital da Guia de Informações ao FGTS e à Previdência Social.

Em inúmeras fiscalizações constatou-se que, mesmo com as contribuições sociais devidas recolhidas, o contribuinte era autuado no valor do tributo já pago por força da

\footnotetext{
${ }^{249}$ A constituição do crédito tributário federal é de competência privativa do Auditor Fiscal da Receita Federal do Brasil, consoante o disposto na Lei ${ }^{\circ} 10.593$, de 2002, artigo $6^{\circ}$, I, a.

${ }^{250}$ Em 3 de dezembro de 2008, foi editada a Medida Provisória no 449, convertida na Lei no 11.941 , em 27 de maio de 2009, que revogou os parágrafos de $4^{\circ}$ a $8^{\circ}$ do artigo 32 da Lei $n^{\circ} 8.212$, de 1991 .
} 
omissão ou incorreção no cumprimento da obrigação acessória. Porém, em inúmeras vezes ele nada recolhia. Para tanto, bastava que não tivesse cometido a mesma falta nos últimos cinco anos, explicitamente pedisse a relevação da multa e, em até trinta dias da autuação, entregasse nova GFIP retificando corretamente a GFIP anterior, ou seja, que alimentasse o banco de dados sociais.

Ao assim agir, a empresa, ou o a ela equiparado, retificava de maneira eficaz seu erro. O trabalhador nada perdia e todo o sistema previdenciário ajustava-se após a atuação do Fisco: havia a constituição do crédito tributário devido, com a pena legalmente prevista, e o trabalhador, destinatário dessa fonte de custeio e segurado obrigatório da Previdência, passava a ter seus dados sociais e seu salário-de-contribuição, sua fonte de custeio, devidamente identificados. Ao reverso, hoje, a sanção posta pela Lei $\mathrm{n}^{\circ} 11.941$, de 2009, demonstra clara opção pela tutela não das informações sociais constantes da GFIP, e sim pela confissão do tributo devido pelo contribuinte. Com isso, a pena cominada no lançamento de ofício do crédito tributário não confessado é forte o suficiente para inibir a conduta de sonegação, função típica de uma obrigação tributária acessória, que é a de apurar e informar o tributo devido, e permitir ao Fisco a necessária conferência.

Mas a GFIP encerra outro fim, o social. Não se pode afirmar que, com os procedimentos hoje adotados, as informações do trabalhador, fulcrais, como vimos, para a obtenção dos benefícios previdenciários, estejam devidamente protegidas. Não há uma pena devida que desestimule a omissão ou incorreção no preenchimento do documento, posto que implica uma multa de vinte reais por 10 campos de registros incorretos ou omitidos. Dois reais por campo.

Em verdade, não há, dentro da fiscalização da Receita Federal do Brasil, a cultura de autuação pelo descumprimento de obrigações acessórias em face da insignificância das penas e, por outro lado, a maximização da punição da conduta omissiva no aspecto da constituição, com multa, do crédito tributário não declarado.

Após 3 de dezembro de 2008, no caso de constituição de crédito de contribuição social de ofício, ou seja, após atuação do Auditor Fiscal da Receita Federal do Brasil, o contribuinte (empresa ou a ela equiparado) que sonegasse o tributo social seria compelido ao pagamento deste, com multa de ofício de $75 \%, 150 \%$, ou $225 \%$, conforme o caso, em face de sua conduta omissiva ou inexata quanto ao preenchimento e envio da GFIP. ${ }^{251}$

${ }^{251}$ Segundo o artigo 35-A da Lei n ${ }^{8} 8.212 / 91$, no caso de lançamento de ofício a multa será de $75 \%$ quando, por exemplo, o contribuinte de informar o tributo devido, ou o fazer com inexatidão. Esse percentual será 
Temos, então, a seguinte situação: o Fisco atua no cumprimento de seu propósito institucional, o contribuinte compulsoriamente paga a contribuição social devida, o Estado arrecada. Os recursos são recolhidos pelo INSS. Todos cumprem seus papéis após a atuação do agente do Estado. Todavia, o trabalhador não tem o resultado da ação estatal revertida em seu proveito, pois o banco de dados do Cadastro Nacional de Informações Sociais não é alimentado pela GFIP.

\subsubsection{Sanções afetas ao FGTS}

A Lei $n^{\circ}$ 8.036, de 1990, que trata do Fundo de Garantia do Tempo de Serviço, apresenta que competirá ao Ministério do Trabalho e da Previdência Social a verificação, em nome da Caixa Econômica Federal, do cumprimento das disposições legais referentes ao FGTS, especialmente quanto à apuração dos débitos e das infrações praticadas pelos empregadores ou tomadores de serviço, notificando-os para efetuarem e comprovarem os depósitos correspondentes e cumprirem as demais determinações legais, podendo, para tanto, contar com o concurso de outros órgãos do Governo Federal, na forma que vier a ser regulamentada.

A Lei $\mathrm{n}^{\circ}$ 8.844, de 1994 , por meio de seu artigo $1^{\circ}$, altera a competência para fiscalizar e apurar as contribuições devidas ao Fundo de Garantia do Tempo de Serviço (FGTS), bem como da aplicação das multas e demais encargos, outorgando-a ao Ministério do Trabalho, por meio dos seus Auditores Fiscais. ${ }^{252}$

O Decreto $\mathrm{n}^{\circ}$ 99.684, de 1990, consolida as normas regulamentares do FGTS e preceitua, em seu artigo 67, que cabe à CEF, na qualidade de Agente Operador do FGTS, expedir atos normativos referentes aos procedimentos administrativos e operacionais dos bancos depositários, dos agentes financeiros e promotores, dos tomadores dos recursos, dos empregadores e dos trabalhadores, integrantes do sistema do FTGS. A CEF, exercendo seu poder normativo, edita a Circular $\mathrm{n}^{\circ} 151$, de 19 de outubro de 1998, que introduz modificações e formulários pertinentes aos recolhimentos dos depósitos do FGTS, da multa rescisória, do depósito do FGTS do mês da rescisão e de mês imediatamente anterior, e define procedimentos atinentes à prestação de informações à Previdência Social, estabelecendo para tal fim a GFIP.

dobrado nos casos de fraude, dolo ou simulação. Além disso, os percentuais de $75 \%$ e $150 \%$ serão acrescidos da metade quando o contribuinte não atender os prazos determinados na intimação.

${ }^{252}$ Lei $^{\circ} 10.593$, de 2002, artigo $3^{\circ}$, inciso III. 
$\mathrm{O}$ artigo 23, parágrafo $1^{\circ}$, inciso III, da mencionada Lei $\mathrm{n}^{\circ}$ 8.036/90, define como infração, entre outras condutas, a de apresentar as informações dos trabalhadores beneficiários ao Cadastro Nacional do Trabalhador ${ }^{253}$ com erros ou omissões. Podemos agora, sustentados pela legislação apresentada, analisar as sanções previstas para o inadimplemento das obrigações acessórias referente ao FGTS.

A Secretaria da Inspeção do Trabalho, órgão do Ministério do Trabalho, editou a Instrução Normativa MTE/SIT $n^{\circ}$ 99, de 23 de agosto de 2012, que vem, no sentido contrário ao da legislação tributária previdenciária, determinar que o esforço dos agentes públicos no cumprimento do seu objetivo fiscal resulte também, diretamente, na eficiência da finalidade social da obrigação adimplida. O Auditor Fiscal do Trabalho, quando em ação fiscal, ${ }^{254}$ deverá verificar a regularidade do recolhimento do FGTS pelo obrigado, seja ele do setor urbano ou rural, público ou privado. O que importa ressaltar, é que, diversamente das ações fiscais empreendidas pela Receita Federal do Brasil, que privilegia a constituição do crédito tributário previdenciário em detrimento das informações sociais prestadas pela GFIP, o Ministério do Trabalho não distingue a sanção quanto à finalidade a ser alcançada, aliando os dois procedimentos, pagar o tributo devido e prestar as informações sociais necessárias. ${ }^{255}$ Tal entendimento decorre das seguintes disposições constantes da Instrução Normativa MTE nº 99, de 23 de agosto de 2012:

Art.17. Ao constatar irregularidade, o AFT deve proceder ao levantamento do débito, individualizado por empregado, e emitir a notificação respectiva para que o empregador recolha a importância devida.

Art. 30. Havendo documentação que, embora incompleta, propicie a identificação de empregados em situação irregular, proceder-se-á ao levantamento por recomposição de folha de pagamento, utilizando-se dados declarados em sistemas informatizados.

$\ldots$

Art. 35. A individualização do valor devido ou recolhido de FGTS na conta vinculada do empregado consiste obrigação do empregador. (grifo nosso)

\footnotetext{
${ }^{253}$ Originalmente, com intuito de criar uma base de dados integrada, o Governo Federal determinou a criação do CNT - Cadastro Nacional do Trabalhador, através do decreto nº 97.936 de 1989, na forma de consórcio entre Ministério da Previdência e Assistência Social (MPAS), Ministério do Trabalho (MTb) e Caixa Econômica Federal (CEF). Posteriormente assumiu, conforme Lei no 8.212 de 1991, a denominação de CNIS.

${ }^{254}$ Segundo o artigo $2^{\circ}$ da Instrução Normativa MTE $n^{\circ}$ 99, de 2012, cabe à SIT (Secretaria de Inspeção do Trabalho) determinar em quais projetos a fiscalização do FGTS será obrigatória.

${ }^{255}$ Alinhamo-nos à corrente doutrinária e jurisprudencial que empresta dupla natureza jurídica ao FGTS, tributo para a empresa e salário diferido ou indenização pelo tempo de serviço para o empregado. Cf. MARTINS, Sergio Pinto. Direito do Trabalho. 23. ed. São Paulo: Atlas, 2007. p. 446; e SILVA. Homero Batista Mateus da. Curso de Direito do Trabalho Aplicado. Rio de Janeiro: Elsevier, 2010. p.238.
} 
As disposições normativas mencionadas demonstram claramente que não é só o interesse de arrecadação que deve prevalecer como produto da ação do Auditor Fiscal do Trabalho (AFT). Além de verificar o recolhimento tempestivo do FGTS, consoante o disposto no artigo 17, ele deve observar se os recolhimentos efetuados foram individualizados, ou seja, se estão depositados em valores cabíveis a cada trabalhador em suas contas vinculadas, conforme preceitua o artigo 33, mesmo reconhecendo ser essa função obrigação do empregador.

Aqui, no que toca ao viés da destinação social, ou seja, em tributos de certa forma vinculados, assim entendidos aqueles que uma vez recolhidos devem ser reconhecidos individualmente $^{256}$ como, por exemplo, a contribuição previdenciária e o FGTS, não cabe ao Fisco verificar só o quantum recolhido, mas também se houve a identificação dos destinatários desse recolhimento, o que, no caso da IN MTE nº 99, observa-se pelos artigos supra transcritos.

Importante ressaltar que tais procedimentos não são decorrentes da recente Instrução Normativa MTE $n^{\circ}$ 99, de 13 de julho de 2012. A Instrução Normativa MTE $n^{\circ}$ 84, de 2010, tinha idêntica disposição. Porém, não muito longe, a Instrução Normativa SIT $\mathrm{n}^{\mathrm{o}} 25$, de 20 de dezembro de 2001, ao disciplinar o levantamento do débito, tinha a seguinte redação:

Art. 21 Examinados os documentos e constatada irregularidade, o AFT procederá ao levantamento do débito e emitirá a notificação respectiva para fins de recolhimento pelo empregador da importância devida. (grifo nosso)

Pequena diferença de redação, porém grande diferença para o trabalhador. A redação da vigente IN MTE $n^{\circ}$ 99/12 determina ao AFT que, se verificada a irregularidade de recolhimento, este deverá realizar o levantamento do devido individualizado por empregado, enquanto a IN SIT n ${ }^{\circ}$ 25/01 determinava o simples levantamento do débito.

O procedimento fiscalizatório hoje determinado aos AFT, quando em ações fiscais tendentes a verificar o adimplemento dos obrigados as questões afetas ao recolhimento e

\footnotetext{
${ }^{256}$ Não se utiliza, neste ponto, o conceito de tributos vinculados e não vinculados a uma atuação estatal, como forma de classificação difundida por Geraldo Ataliba e aplicável ao Direito Tributário. Com a devida permissão, pretende-se somente deixar claro ao leitor que o caráter tributário presente no FGTS e na contribuição previdenciária deve ser sopesado com a característica social do tributos mencionados. Na menção a Geraldo Ataliba, cf. BARRETO, Paulo Ayres. Contribuições: regime jurídico, destinação e controle. São Paulo: Noeses, 2006.
} 
informações do FGTS, valoriza a função social dos Auditores Fiscais do Trabalho, pois eles, cumprindo sua missão institucional, obrigam as empresas e aqueles a ela equiparados pela legislação do FGTS a cumprir as normas vigentes e recolher o devido. O FGTS é recolhido em função dessa atuação. O trabalhador, destinatário final desses recursos, é beneficiado, pois é em sua conta vinculada que repousará o valor recolhido por seu empregador. Assim, a função social será cumprida em virtude da atuação do Estado.

Porém, infelizmente, como visto, isso não acontece quando da atuação do Auditor Fiscal da Receita Federal do Brasil: o Estado arrecada e o trabalhador não aproveita os recursos e não se beneficia do trabalho da fiscalização.

\subsubsection{Sanções penais}

Os crimes contra a Seguridade Social estão hoje dispostos no Código Penal, por força de alteração ocorrida em 2000, com o advento da Lei ${ }^{\circ}$ 9.983, revogando grande parte do artigo 95 da Lei $n^{\circ}$ 8.212, de 1991, Lei de Custeio da Previdência Social que dispunha sobre a matéria.

Mantendo-nos coerentes com o propósito do presente estudo, analisaremos somente as condutas tipificadas penalmente afetas a Guia de Informações do FGTS e à Previdência Social. A primeira delas, o crime de sonegação de contribuição previdenciária consta do artigo 337-A do Código Penal, que tem a seguinte redação:

"Art. 337-A. Suprimir ou reduzir contribuição social previdenciária e qualquer acessório, mediante as seguintes condutas:

I - omitir de folha de pagamento da empresa ou de documento de informações previsto pela legislação previdenciária segurados empregado, empresário, trabalhador avulso ou trabalhador autônomo ou a este equiparado que lhe prestem serviços;

II - deixar de lançar mensalmente nos títulos próprios da contabilidade da empresa as quantias descontadas dos segurados ou as devidas pelo empregador ou pelo tomador de serviços;

III - omitir, total ou parcialmente, receitas ou lucros auferidos, remunerações pagas ou creditadas e demais fatos geradores de contribuições sociais previdenciárias:

Pena - reclusão, de 2 (dois) a 5 (cinco) anos, e multa.

$\S 1^{\circ}$ É extinta a punibilidade se o agente, espontaneamente, declara e confessa as contribuições, importâncias ou valores e presta as informações devidas à previdência social, na forma definida em lei ou regulamento, antes do início da ação fiscal.

$\S 2^{\mathrm{o}}$ É facultado ao juiz deixar de aplicar a pena ou aplicar somente a de multa se o agente for primário e de bons antecedentes, desde que:

I - (VETADO) 
II - o valor das contribuições devidas, inclusive acessórios, seja igual ou inferior àquele estabelecido pela previdência social, administrativamente, como sendo o mínimo para o ajuizamento de suas execuções fiscais.

$\S 3^{0}$ Se o empregador não é pessoa jurídica e sua folha de pagamento mensal não ultrapassa $\mathrm{R} \$ 1.510,00$ (um mil, quinhentos e dez reais), o juiz poderá reduzir a pena de um terço até a metade ou aplicar apenas a de multa.

$\S 4^{\mathrm{o}} \mathrm{O}$ valor a que se refere o parágrafo anterior será reajustado nas mesmas datas e nos mesmos índices do reajuste dos benefícios da previdência social" (grifos não constam do texto legal)

Conduta tipificada inserida no Código em seu Título referente aos crimes contra a Administração Pública praticado por particular, a sonegação de contribuições previdenciárias é crime material, posto que o resultado compõe o tipo, uma vez que é necessário que exista a supressão ou redução da contribuição social, sendo também conduta omissiva. Crime doloso, pois se houver simples erro, estaríamos diante de exclusão de antijuridicidade, persistindo porém o ilícito administrativo.

Analisando o tipo penal, observamos, no inciso I, a efetiva proteção do documento de informações da Previdência Social. Em que pese a conduta delituosa claramente tutelar o interesse de arrecadação, protegendo ingresso de recursos da Seguridade Social, há na dicção da lei a menção ao documento de suporte das informações previdenciárias com referência aos dados específicos do trabalhador, inclusive com menção a diversidade de vínculos, de forma de contrato de trabalho.

Importa realçarmos com tinta forte, que a extinção de punibilidade, antes do início da ação fiscal, passa pela correção das informações prestadas, e nesse sentido, há efetiva proteção das informações sociais dos trabalhadores prejudicados pela conduta antijurídica praticada. Tal afirmação decorre da previsão do $\S 1^{\circ}$, acima transcrito e sublinhado, que se consubstancia no uso da conjunção "e" ao prescrever que a extinção de punição prevista se dá com a declaração e confissão dos valores devidos e com a prestação das informações devidas à previdência social. Ora, para se prestar as informações devidas na forma prevista na lei ou no regulamento, deve-se preencher e transmitir a GFIP.

Por fim, nos posicionamos ao lado de Zambitte, ${ }^{257}$ ao entender que há extinção da punibilidade do crime de sonegação de contribuição previdenciária quando houver o pagamento antes do oferecimento da denúncia, por analogia à disposição do artigo 34 da Lei n 9.249, de 1995, uma vez que o Código Penal não regulamentou a possibilidade,

${ }^{257}$ IBRAHIM, Fábio Zambitte. Curso de direito previdenciário. 16ª ed. Niterói: Ed. Impetus, 2011. p. 472. 
tratando somente da ação antes do início da ação fiscal. Sendo uma analogia benéfica ao réu e este cumprindo as condições da lei penal para o caso, entendemos ter o acusado direito à extinção da punibilidade.

Além do crime de sonegação de contribuição previdenciária, há proteção dos dados constantes da GFIP na conduta definida como falsificação de documento público, prevista no artigo 297, abaixo reproduzido:

\footnotetext{
"Art. 297 - Falsificar, no todo ou em parte, documento público, ou alterar documento público verdadeiro:

Pena - reclusão, de dois a seis anos, e multa.

$\S 1^{\circ}$ - Se o agente é funcionário público, e comete o crime prevalecendose do cargo, aumenta-se a pena de sexta parte.

$\S 2^{\circ}$ - Para os efeitos penais, equiparam-se a documento público o emanado de entidade paraestatal, o título ao portador ou transmissível por endosso, as ações de sociedade comercial, os livros mercantis e o testamento particular.

$\S 3^{\circ}$ Nas mesmas penas incorre quem insere ou faz inserir:

I - na folha de pagamento ou em documento de informações que seja destinado a fazer prova perante a previdência social, pessoa que não possua a qualidade de segurado obrigatório;

II - na Carteira de Trabalho e Previdência Social do empregado ou em documento que deva produzir efeito perante a previdência social, declaração falsa ou diversa da que deveria ter sido escrita;

III - em documento contábil ou em qualquer outro documento relacionado com as obrigações da empresa perante a previdência social, declaração falsa ou diversa da que deveria ter constado. $\S 4^{\underline{0}}$ Nas mesmas penas incorre quem omite, nos documentos mencionados no $\S 3^{\mathbf{o}}$, nome do segurado e seus dados pessoais, a remuneração, a vigência do contrato de trabalho ou de prestação de serviços" (grifamos)
}

Protege-se a veracidade das informações prestadas nos documentos mencionados, sem dúvida, em face da importância que os documentos listados têm para a Previdência Social por conta da inversão do ônus da prova quando da concessão de qualquer benefício previdenciário.

Crimes dolosos e formais, pois se consumam com o simples 'facere', a conduta prevista no parágrafo $3^{\circ}$ é comissiva, uma vez que se pune quem insere ou faz inserir a informação falsa. Por outro lado, temos no parágrafo $4^{\circ}$, conduta omissiva, consubstanciada na omissão da informação elencada no tipo. Claro que nesse caso, havendo o intuito de deixar de pagar contribuição previdenciária teremos a absorção deste 
tipo pelo crime de sonegação previdenciária, visto acima, não se configurando concurso de crimes. $^{258}$

Inegável a tutela da GFIP no caso em apreço. Consubstancia toda a importância que defendemos para o documento de informações no sentido da garantia de acesso do trabalhador ao correto benefício previdenciário que tem direito.

${ }^{258}$ O STJ já assentou que "a sonegação fiscal absorve a falsidade, quando esta é o meio fraudulento empregado para a prática do delito tributário” . Cf STJ, RHC 1.506/SP, Rel. Min Carlos Thibau. DJ 10/12/91. 


\section{CAPÍTULO 6 - ASPECTOS RELEVANTES DO CNIS - CADASTRO NACIONAL DE INFORMAÇÕES SOCIAIS}

\subsection{O que é o CNIS}

No começo da década de 90, o Estado brasileiro passava por um momento peculiar. Fortalecido pela democracia que se desenvolvia, no bojo da primeira eleição direta para a Presidência da República depois de mais de 20 anos de ditadura militar, enfrentava turbulência econômica causada pela inflação crônica, falta de poupança interna, gastos públicos superiores à receita, e pauta pífia de exportações centrada em commodities.

Obcecado pela modernização do Estado, o presidente eleito Fernando Collor contaminou o debate público sobre o modelo estatal ao firmar duas premissas falsas: a ideia de Estado mínimo e o conceito de 'marajás', imputado ao funcionalismo público. Tais pressupostos levaram a medidas que causaram o desmantelamento de políticas públicas e redução de atividades estatais essenciais, além da transformação do funcionário público em responsável pelos problemas nacionais, com previsível consequência na prestação dos serviços prestados pelo Estado. ${ }^{259}$

O governo de Itamar Franco, se não produziu grandes reformas, prestou-se à realização de importantes estudos sobre o tema, permitindo a Fernando Henrique Cardoso, que o sucedeu na Presidência da República, criar o Ministério da Administração e Reforma do Estado, comandado por Luiz Carlos Bresser Pereira. É nesse cenário que se cria e se desenvolve o Cadastro Nacional de Informações Sociais (CNIS). Vejamos a evolução histórica.

Logo após a promulgação da Carta da República de 1988, chamada Carta Cidadã devido ao plexo de direitos por ela assegurados, é instituído o Cadastro Nacional do

\footnotetext{
259 ABRUCIO, Fernando Luiz. Trajetória recente da gestão pública brasileira: um balanço crítico e a renovação da agenda de reformas. Disponível em: <http://www.scielo.br/scielo.php?script=sci_arttext\&pid=S0034-76122007000700005>. Acesso em: 24 out. 2012.
} 
Trabalhador (CNT), por meio do Decreto $\mathrm{n}^{\circ}$ 97.936, de 10 de julho de 1989, para registrar as informações de interesse do trabalhador, do Ministério do Trabalho e da Previdência Social e da Caixa Econômica Federal.

Explicitava o citado Decreto ${ }^{\circ}$ 97.936, que o CNT, seria composto pelo sistema de identificação do trabalhador e pelo sistema de coleta de informações sociais, com os dados das pessoas já inscritas no Programa de Integração Social (PIS) e no Programa de Formação do Patrimônio do Servidor Público (PASEP), além dos trabalhadores cadastrados no sistema de contribuinte individual da Previdência Social. Com isso, ficava demonstrado que a organização inicial do CNT seria feita a partir de informações constantes dos cadastros do PIS, do PASEP, além dos dados dos contribuintes individuais constantes do sistema previdenciário.

Ao lado dos trabalhadores já identificados, cujos dados migrariam para o CNT, para os novos cadastrados seriam instituídos o Número de Identificação do Trabalhador (NIT) e o Documento de Cadastramento do Trabalhador (DCT), esse em substituição da Ficha de Declaração de que trata o $\S 2^{\circ}$ do art. 13 da Consolidação das Leis do Trabalho CLT. $^{260}$

O DCT deveria ser preenchido por vários entes do Estado, como os postos competentes, a cada emissão da Carteira do Trabalho e Previdência Social (CTPS) e no caso de contribuintes individuais, pela Previdência Social, que poderia utilizar-se dos serviços da rede bancária. Caberia ainda aos órgãos e entidades da Administração Pública identificar os trabalhadores do serviço público não regidos pela CLT ainda não inscritos no CNT. A cada trabalhador seria atribuído um NIT, que lhe facultaria o acesso às informações referentes aos seus direitos trabalhistas e previdenciários.

Explicitava ainda o Decreto $\mathrm{n}^{\circ} 97.936$ que a coleta de informações sociais seria feita por meio do Documento de Informações Sociais (DIS), a ser preenchido pelos empregadores, que deveriam identificar-se pelo número de inscrição no Cadastro Geral de Contribuintes do Ministério da Fazenda (CGC/MF) e identificar cada trabalhador pelo respectivo NIT.

\footnotetext{
${ }^{260}$ Conforme a CLT: "Art. 13 - A Carteira de Trabalho e Previdência Social é obrigatória para o exercício de qualquer emprego, inclusive de natureza rural, ainda que em caráter temporário, e para o exercício por conta própria de atividade profissional remunerada.

$\S 2^{\circ}$ - A Carteira de Trabalho e Previdência Social e respectiva Ficha de Declaração obedecerão aos modelos que o Ministério do Trabalho e Previdência Social adotar."
} 
Demonstrando que o sistema concebido, ainda em 1989, tinha a mesma arquitetura que o sistema atual, GFIP/CNIS, o mencionado decreto determinava que o DIS conteria, além de outras informações de menor interesse ao presente trabalho, informações relativas ao controle dos registros pertinentes ao Fundo de Garantia do Tempo de Serviço (FGTS); ao salário de contribuição do trabalhador, para concessão e manutenção de benefícios por parte da Previdência Social; ao pagamento do abono previsto pelo $§ 3^{\circ}$ do art. 239 da Constituição, chamado abono do PIS/PASEP; ao pagamento e controle do segurodesemprego; e, por fim, à admissão e dispensa de empregados.

Foi também criado o Grupo Gestor do CNT, encarregado de administrar e fiscalizar a implantação e a operação do CNT, sob a Presidência do Secretário da Administração Federal, e composto por um representante do Ministério do Trabalho e da Previdência Social (MTPS), da Caixa Econômica Federal (CEF), dos trabalhadores e dos empregadores.

De modo a dar concretude ao CNT, no caso de descumprimento das obrigações impostas pelo Decreto $\mathrm{n}^{\circ}$ 97.936, os infratores estariam sujeitos, conforme a infração, às

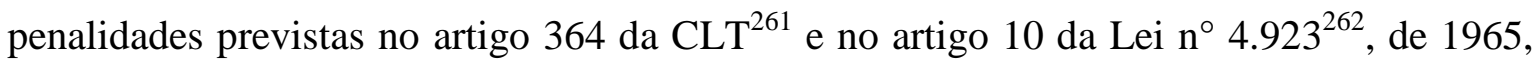
sendo que, no caso de mais de uma infração, as respectivas penalidades seriam aplicadas cumulativamente.

O Decreto $\mathrm{n}^{\circ} 97.936$ foi alterado em 1990, pelo Decreto $\mathrm{n}^{\circ} 99.378$, somente em função da unificação do Ministério do Trabalho com o Ministério da Previdência Social. Porém, a nova redação do artigo $7^{\circ}$, embora indique pequena mudança de texto, impõe importante alteração do ponto de vista prático, pois introduz a empresa de processamento de dados da Previdência Social (DATAPREV) na operacionalização do CNT.

Com o advento da Lei $\mathrm{n}^{\circ}$ 8.490, de 1992, que dispunha sobre a organização da Presidência da República e dos Ministérios, altera-se a denominação do Cadastro Nacional do Trabalhador para Cadastro Nacional de Informações Sociais (CNIS) nomenclatura até hoje vigente.

\footnotetext{
${ }^{261}$ CLT, "art. 364 - As infrações do presente Capítulo serão punidas com a multa de cem a dez mil cruzeiros."

${ }^{262}$ Lei $\mathrm{n}^{\circ}$ 4923, Lei do CAGED: “Art. 10: A falta da comunicação a que se refere o parágrafo único do art. $1^{\circ}$ desta Lei, no prazo ali estipulado, importará na aplicação automática de multa no valor de $1 / 3$ (um terço) do salário-mínimo regional, por empregado, de competência da Delegacia Regional do Trabalho.

Parágrafo único. A multa prevista no artigo ficará reduzida para 1/9 (um nono) e 1/6 (um sexto) do saláriomínimo regional, por empregado, quando, antes de qualquer procedimento fiscal por parte do Ministério do Trabalho e Previdência Social, a comunicação for feita, respectivamente, dentro de 30 (trinta) ou 60 (sessenta) dias, após o término do prazo fixado."
} 
Pode-se dizer que o Cadastro Nacional de Informações Sociais é um projeto de governo, pois envolve, além dos órgãos encarregados da gestão dos direitos sociais, como o Ministério da Previdência e o Ministério do Trabalho e a Caixa Econômica Federal, gestora do FGTS, a Secretaria da Receita Federal do Brasil e o Banco do Brasil. Pode-se ainda afirmar que foi criado com o objetivo de ser uma base de dados que registra as informações necessárias para a garantia dos direitos trabalhistas e previdenciários dos trabalhadores brasileiros. Iniciativa governamental que pretende viabilizar a gestão dos direitos sociais dos trabalhadores, para tanto, objetiva, ainda, a liberação do ônus da prova para benefícios, a inibição de fraudes na concessão de benefícios, o controle da arrecadação e direcionamento da fiscalização, a simplificação da coleta de informações sociais, o gerenciamento racional das informações do Governo e subsidiar o planejamento de políticas públicas.

A cada um dos órgãos envolvidos atribuem-se funções específicas. Ao Banco do Brasil cabe o fornecimento de informações cadastrais obtidas com o PASEP, que é administrado pelo Banco. À Receita Federal do Brasil compete prestar as informações referentes ao cadastro das pessoas jurídicas, disponíveis pelo controle dos CNPJs e das matrículas CEI, o Cadastro Específico do INSS, gerido desde a unificação dos físcos federais $^{263}$ pela RFB. O Ministério do Trabalho e Emprego, através de dados do CAGED e da RAIS, por seu turno, deve informar os dados cadastrais e de vínculo das pessoas constantes dos sistemas de gerenciamento de relações sociais vigentes até 1998. Já o Ministério da Previdência Social deve povoar os dados dos trabalhadores sem vínculo de emprego, com base nas informações dos contribuintes individuais, e os dados de recolhimento de contribuições previdenciárias, com base nas informações do sistema de recolhimento de GPS, além da óbvia alimentação com os dados dos beneficiários da Previdência e Assistência Sociais. Por fim, a mais importante fonte de dados do CNIS, que é a Guia de Informações ao FGTS e à Previdência Social, a GFIP, de responsabilidade da CAIXA, a quem compete ainda as informações oriundas do PIS.

O CNIS é hospedado nos computadores da DATAPREV e contém registros de dados cadastrais de mais de 206 milhões de pessoas físicas, 577 milhões de vínculos, 15,4 bilhões de remunerações cadastradas, 1,8 bilhões de contribuições e 29,6 milhões de

\footnotetext{
${ }^{263}$ Lei $\mathrm{n}^{\circ}$ 11.457, de 16 de março de 2007, unificou a Secretaria da Receita Previdenciária e a Secretaria da Receita Federal, originando a Secretaria da Receita Federal do Brasil.
} 
pessoas jurídicas. ${ }^{264}$ Por causa da grandeza dos números contidos no CNIS, existem, por força de convênio, vários órgãos externos que se utilizam do sistema, como o Ministério Público Federal, os Tribunais Regionais Federais, o Ministério da Justiça, a Polícia Federal, o Ministério do Planejamento, Orçamento e Gestão, o Ministério da Fazenda (COAF), a Agência Brasileira de Inteligência, o Instituto Pesquisa Econômica Aplicada (IPEA), a Controladoria-Geral da União (CGU), o Tribunal de Contas da União, o INCRA etc.

Estruturado em quatro partes, o Cadastro Nacional de Informações Sociais é formado por um Cadastro de Trabalhadores, que contém os dados básicos e complementares de pessoas físicas engajadas em atividades produtivas. Incluem-se neste universo os trabalhadores empregados ou contribuintes individuais, tais como empresários, funcionários públicos, ou quaisquer pessoas detentoras de NIT, PIS ou PASEP e que tenham informado a partir de 1971 (para empregados) ou 1973 (para contribuintes individuais) seus dados sociais ou previdenciários ao governo federal. São fontes deste cadastro PIS/PASEP, RAIS, FGTS, CAGED, Cadastro de Contribuintes Individuais e GFIP.

Já o Cadastro de Empregadores, segundo grande banco do CNIS, possui os dados cadastrais de pessoas jurídicas e de estabelecimentos empregadores reconhecidos pela Previdência Social. Todos os estabelecimentos empregadores, independente do ramo de suas atividades (rural, comercial, industrial, etc), que tenham fornecido dados sociais, previdenciários ou fiscais ao governo federal a partir de 1964 estarão cadastrados. Povoam este cadastro o CNPJ, o Cadastro de Empregadores do INSS, RAIS, CAGED e GFIP.

Os dados de vínculos empregatícios desde 1976 e respectivas remunerações mensais a partir de 1990, além de recolhimentos dos contribuintes individuais efetuados mensalmente através de carnê (Guia de Recolhimento do Contribuinte Individual - GRCI) desde 1979, fazem parte do terceiro grupo de informação do CNIS, o chamado Cadastro de Vínculos Empregatícios e de Remunerações do Trabalhador Empregado e de Recolhimentos do Contribuinte Individual. As informações dos vínculos empregatícios/ remunerações e recolhimentos de contribuintes individuais permitem determinar o tempo de serviço do trabalhador e o valor do seu benefício previdenciário. Os dados são obtidos para abastecer os vínculos empregatícios na RAIS, no FGTS, no CAGED e na GFIP. Para informar as Remunerações do Trabalhador, socorre-se de dados da RAIS e da GFIP. Já

\footnotetext{
${ }^{264}$ Segundo dados de setembro de 2010 da Assessoria de Cadastros Corporativos do MPS. Disponível em: <http://www.enap.gov.br/files/cnis.pdf〉. Acesso em: 25 out. 2012.
} 
para os Recolhimentos do CI, recorre-se à Base de Recolhimentos do CI constantes do banco de dados do INSS.

Por fim, o quarto grande banco do CNIS, o cadastro de Agregados de Vínculos Empregatícios e de Remunerações por Estabelecimento Empregador, contém dados acumulados de vínculos empregatícios e remunerações mensais, fornecendo uma visão gerencial de massa salarial e quantidade de vínculos. Permite a realização de confrontos com as bases de Arrecadação da Previdência Social para detectar possíveis divergências entre contribuição potencial e contribuição efetiva. É abastecido pela RAIS e GFIP.

Todo esse conteúdo armazenado em quatro grandes bases de dados - conforme a sua natureza - e é atualizado por meio de diversos processos e aplicativos online, disponíveis na internet para uso dos segurados. Para os servidores do INSS que prestam atendimento ao público nas Agências da Previdência Social (APS), esse conteúdo é acessado por meio dos sistemas internos da Previdência Social (Intranet).

Em resumo, temos que o CNIS concentra as informações de todos trabalhadores cadastrados nos principais bancos de dados da administração pública e objetiva a concessão e o gerenciamento dos benefícios previdenciários, assistencialistas e trabalhistas previstos na legislação social brasileira. Conhecido o grande armazenador de informações do trabalhador, veremos, nas seções a seguir, como se faz, hoje, a inserção de dados no sistema, se há possibilidade de alteração desses dados e como essas informações são efetivamente utilizadas. Veremos, ainda, como se deve dar proteção ao CNIS.

\subsection{Inserção de dados do trabalhador}

Quando esmiuçamos a Guia de Informações ao FGTS e à Previdência Social destacamos que quando o trabalhador presta serviços à empresa, ou ao a ela equiparado, o artigo 32 da Lei $\mathrm{n}^{\circ}$ 8.212, de 1991, obriga que estes informem todos os dados dos trabalhadores, do vínculo de trabalho, e da consequente remuneração por meio da GFIP. Apontamos, também, que cabe ao contratante tomar as providências no sentido da inscrição do trabalhador na Previdência Social, quando for o caso. ${ }^{265}$

Podemos, portanto, entender que o atual arcabouço legislativo imputa à empresa, e ao a ela equiparado, o dever de abastecer, de inserir os dados do trabalhador no sistema CNIS. O adimplemento desta obrigação se dá mensalmente, nos termos do artigo 225 ,

\footnotetext{
${ }^{265}$ Para maiores considerações, ver item 4.3.
} 
inciso IV, do Regulamento da Previdência Social, aprovado pelo Decreto $\mathrm{n}^{\circ} 3.048$, de 1999, permitindo que o CNIS tenha atualização alinhada com a remuneração percebida pelo trabalhador, tanto dos valores dessa remuneração quanto das eventuais ocorrências afetas à relação de trabalho, como, por exemplo, necessidade de cobertura previdenciária.

Todavia, devemos recordar que toda pessoa física que vive do seu trabalho, sob qualquer título, obtendo renda por meio desse trabalho, é segurado obrigatório do INSS, tendo direito aos benefícios previdenciários e o dever de recolher a contribuição previdenciária cabível. Nesse sentido, devemos ressalvar que nem todos trabalhadores prestam serviços a empresas ou a pessoas a elas equiparadas. Existe um número significativo de pessoas que trabalham para outras pessoas físicas desobrigadas da entrega da GFIP, como os trabalhadores domésticos e outro tanto de pessoas que trabalham por sua própria conta e risco. Todos esses trabalhadores também são segurados obrigatórios da Previdência Social. Verifiquemos como os dados destes trabalhadores são inseridos no Cadastro Nacional de Informações Sociais.

A Lei de Benefícios, Lei $\mathrm{n}^{\circ}$ 8.213, de 1991, estipula em seu artigo 11, inciso V, que são segurados obrigatórios da Previdência Social, categoria contribuinte individual, dentre outros, a pessoa física que exerce, por conta própria, atividade econômica de natureza urbana, com fins lucrativos ou não. Dispondo sobre a contribuição deste antigo autônomo, hoje contribuinte individual, a Lei de Custeio da Previdência Social explicita, no artigo 30, inciso II que ele deve recolher sua contribuição, por iniciativa própria, até o dia 15 do mês subsequente ao da competência em que ele auferiu a renda.

Vimos alhures que o CNIS é alimentado, dentre outros, pela base de recolhimentos do CI constantes do banco de dados do INSS, ou seja, quando um contribuinte individual paga sua guia GPS, identificada com um código de pagamento vinculado à categoria contribuinte individual, essa informação fatalmente é inserida no sistema nacional de informações. Logo, a existência do necessário sistema de controle de arrecadação por parte da Autarquia Previdenciária permite ao trabalhador dito autônomo ter a garantia de que sua contribuição à Previdência Social reflita na inserção de seus dados no Cadastro Nacional de Informações Sociais, o que como sabemos, é a porta de acesso aos direitos ofertados pelo Estado de Bem-Estar Social que se constrói no Brasil.

Importante realçarmos que tal dispositivo de inserção de dados, atrelado ao pagamento da contribuição devida, coaduna-se com as disposições legais relativas aos benefícios previdenciários devido aos segurados contribuintes individuais, pois estes, 
quando laboram autonomamente, são os próprios responsáveis pela sua contribuição, e por ser a Previdência Social o sistema da Seguridade Social contributivo por excelência, ${ }^{266}$ não há nenhum paradoxo quando se utiliza o próprio recolhimento do contribuinte individual como garantia de acesso aos benefícios previdenciários.

Ressalte-se ainda que, estando este mesmo trabalhador desobrigado do recolhimento, por estar no gozo de algum benefício previdenciário, essa situação também será reconhecida pelo CNIS uma vez que o INSS informa ao Cadastro Nacional todos os benefícios previdenciários dos trabalhadores segurados.

Todo o acima dito para o contribuinte individual é aplicável ao doméstico, alterando-se o que deve ser alterado, uma vez que o recolhimento deste segurado é realizado pelo empregador, que também o faz por meio de GPS. Ressalve-se que, por liberalidade do empregador, este poderá recolher o FGTS para o doméstico, e, neste caso, estará obrigado ao preenchimento e envio da GFIP, tornando, nesta hipótese, o povoamento de dados do CNIS relativo ao empregado doméstico muito mais seguro e confiável.

Visto que os trabalhadores que prestam serviços à empresa, ou aos equiparados, têm seus dados inseridos no CNIS via GFIP, e que quanto aos autônomos e domésticos, a inserção se dá pelo recolhimento da contribuição mensal e pelo sistema de gerenciamento de benefícios, quando o trabalhador estiver usufruindo de algum, verifiquemos agora o caso do segurado especial, uma vez que esse segurado obrigatório da Previdência Social tem situação ímpar no sistema previdenciário brasileiro.

A Lei ${ }^{\circ}$ 8.213, de 1991, no mencionado artigo 11, agora no inciso VII, define:

VII - como segurado especial: a pessoa física residente no imóvel rural ou em aglomerado urbano ou rural próximo a ele que, individualmente ou em regime de economia familiar, ainda que com o auxílio eventual de terceiros, na condição de:

a) produtor, seja proprietário, usufrutuário, possuidor, assentado, parceiro ou meeiro outorgados, comodatário ou arrendatário rurais, que explore atividade:

1. agropecuária em área de até 4 (quatro) módulos fiscais;

2. de seringueiro ou extrativista vegetal que exerça suas atividades nos termos do inciso XII do caput do art. $2^{\circ}$ da Lei $\mathrm{n}^{\circ} 9.985$, de 18 de julho de 2000 , e faça dessas atividades o principal meio de vida;

b) pescador artesanal ou a este assemelhado que faça da pesca profissão habitual ou principal meio de vida; e

\footnotetext{
${ }^{266}$ Constituição Federal, artigo 201: “A previdência social será organizada sob a forma de regime geral, de caráter contributivo e filiação obrigatória [...]."
} 
c) cônjuge ou companheiro, bem como filho maior de 16 (dezesseis) anos de idade ou a este equiparado, do segurado de que tratam as alíneas a e b deste inciso, que, comprovadamente, trabalhem com o grupo familiar respectivo.

Por regime de economia familiar, segundo o parágrafo $1^{\circ}$, entende-se o trabalho realizado pelos membros da família que é indispensável à própria subsistência e ao desenvolvimento socioeconômico do núcleo familiar. Condição para que se configure como tal é que o trabalho seja exercido em condições de mútua dependência e colaboração, sem a utilização de empregados permanentes.

Do artigo exposto, depreende-se que o segurado especial é aquele que, ainda que contando com o trabalho conjunto de sua família, vive em regime rudimentar de produção, ou seja, praticando o que se consagrou como sendo economia de subsistência. Temos, por convicção, que o segurado especial - do ponto de vista econômico - não vive, sobrevive.

A esta categoria de segurado, propriamente denominada especial, a Carta de $1988^{267}$ previu uma contribuição previdenciária diferenciada, incidente sobre a renda bruta proveniente da comercialização da produção rural do segurado especial. Importante ressaltar que a contribuição sobre a comercialização da produção do segurado especial é a contribuição dele segurado especial, da pessoa física, e também de todos da família que contribuem para o regime de economia familiar típico deste tipo de segurado obrigatório da Previdência Social.

Devemos notar que o recolhimento da contribuição incidente sobre a comercialização da produção do segurado especial tem sutilezas determinadas pela Lei de Custeio. Há substituição tributária também quanto ao responsável pelo recolhimento, pois cabe ao adquirente dos produtos rurais comercializados pelo segurado especial, se for este adquirente pessoa jurídica, reter e recolher os $2,1 \%$ incidentes sobre o valor da comercialização da produção.

Diante das considerações acima, podemos inferir que a inserção de dados do segurado especial no CNIS caminha de maneira distinta, porém convergente com as dos demais segurados. Se houver a substituição tributária quanto à responsabilidade pelo recolhimento, ou seja, se a produção rural for adquirida por uma pessoa jurídica, ou

\footnotetext{
${ }^{267}$ Artigo 195, parágrafo $8^{\circ}$.
} 
equiparado, caberá a este adquirente informar em sua própria GFIP a retenção efetuada, ${ }^{268}$ e portanto, o CNIS será abastecido, com os dados do segurado, via GFIP. Em outro giro, se a comercialização for realizada entre o segurado especial e outra pessoa física, ou no caso de venda no varejo, caberá ao próprio segurado especial recolher a respectiva GPS, e assim, teremos as informações migrando segundo o mesmo rito do contribuinte individual, isto é, via sistema de arrecadação das contribuições do INSS.

\subsection{Alteração dos dados do trabalhador}

Inegável a necessidade de previsão de alteração dos dados sociais do trabalhador. Por vezes, erros ocorrem. Por vezes, situações jurídicas estabelecidas devem ser revistas. Por vezes, falhas na transmissão dos dados ou no seu processamento podem existir. Logo, um sistema destinado a ser o suporte para o gozo de direitos deve ser flexível o suficiente para sofrer, quando necessário, alterações nos dados nele armazenados. Tal atributo foi concebido para o Cadastro Nacional de Informações Sociais.

Para sistematizarmos nossa análise sobre a alteração de dados do CNIS, dividiremos nossa observação em duas situações possíveis, a alteração dos dados comandada pelos encarregados de povoar o banco de dados do trabalhador, aos quais chamaremos de alimentadores, na falta de denominação melhor; e a alteração dos dados pelo próprio trabalhador.

\subsubsection{A alteração dos dados pelos alimentadores do CNIS}

A nós parece claro que a GFIP é o maior meio de povoar o banco de dados do trabalhador brasileiro. Tal afirmação decorre da quantidade de informações constantes no documento, da magnitude do número de obrigados ao seu preenchimento e consequente envio, e da diversidade das informações constantes na guia de declaração.

Dispensa maiores considerações a simples lembrança de que a GFIP contém todos os dados do empregador, todos os dados dos trabalhadores que prestaram serviço a este empregador, mais todos os dados relativos aos fatos geradores de contribuição previdenciária dos trabalhadores, dos prestadores de serviço mediante cessão de mão-deobra e das cooperativas que prestaram serviço a este empregador, além das aquisições de

\footnotetext{
${ }^{268}$ Para maior detalhamento, ver item 4.4.6.
} 
produtos rurais efetuadas por este empregador, e mais, os fatos geradores de contribuições previdenciárias e fundiárias do empregador, acrescidos das compensações efetuadas por esse contribuinte.

Em um documento de tamanha complexidade, a ocorrência de erros é totalmente concebível. A GFIP, uma vez transmitida pelo sistema SEFIP, é base de dados do CNIS, e quando apresenta incorreções, naturalmente acarreta consequências.

Não obstante efeitos tributários indesejados, ${ }^{269}$ que não são objeto do presente trabalho, tais vícios prejudicam a confiabilidade das informações armazenadas no CNIS, e podem, eventualmente, prejudicar o trabalhador quando do gozo de algum benefício previdenciário.

Tal situação pode ser facilmente corrigida pelo faltoso com a emissão de uma GFIP retificadora, elaborada conforme as orientações do Manual da GFIP. ${ }^{270} \mathrm{O}$ envio da correção altera os dados do trabalhador, permitindo a obtenção, pelo valor devido, de qualquer benefício previdenciário, ou gozo de direito social implementado pelos dados constantes do CNIS.

Contudo, o cadastro de informações sociais não é alimentado somente pela GFIP, pois, como já mencionado, um sem número de trabalhadores não se vinculam à empresa, tendo seus dados inseridos por outros sistemas que não o SEFIP/GFIP. Quando esses trabalhadores estiverem no gozo de benefícios previdenciários, seus dados serão enviados ao CNIS por intermédio do sistema de benefícios do INSS. Em que pese menor possibilidade de erro, se ocorrerem, quando a autarquia previdenciária corrigi-los, e por óbvio o fará por via de seu sistema de benefício, tal retificação alterará os dados do trabalhador beneficiado no CNIS, uma vez que a alimentação é online.

Os dados dos trabalhadores que não prestam serviços a empresas surgem no CNIS de duas maneiras distintas. O cadastro é realizado por meio do sistema do INSS, denominado cadastro de contribuintes individuais, que alimenta um dos quatro grandes bancos armazenadores de dados do CNIS, o Cadastro dos Trabalhadores. Logo, a retificação dessas informações pressupõe que o trabalhador demande que a Autarquia Previdenciária o faça, ou, se for o caso, que o INSS altere o cadastro do trabalhador de ofício. O mesmo ocorre para o segurado especial e para o doméstico.

\footnotetext{
${ }^{269} \mathrm{O}$ artigo 32, inciso IV, § $2^{\circ}$, da Lei n ${ }^{\circ} 8.212$, de 1991, com a redação da Lei n ${ }^{\circ} 11.941$, de 2009, explicita o caráter de confissão de dívida da Guia de Informações à Previdência Social.

270 O Capítulo V do Manual da GFIP, aprovado pela Instrução Normativa RFB nº 880, de 2008, trata da retificação das informações.
} 
De fato, dados cadastrais, usualmente, são pouco alterados ao longo do tempo. Normalmente se tornam relevantes apenas no caso de necessidade de comunicação do órgão com o trabalhador, o que, de modo geral, ocorre a pedido do trabalhador, havendo assim atualização dos dados cadastrais.

As informações mais importantes que constam do CNIS, especialmente com relação ao segurado contribuinte individual, ao doméstico e ao segurado especial, dizem respeito às suas contribuições, pois são elas que garantem a manutenção da qualidade de segurado, consoante o disposto na Lei $\mathrm{n}^{\circ} 8.213,{ }^{271}$ de 1991 , além de comporem o saláriode-benefício dele.

Recordando-se que os dados do contribuinte individual, do doméstico e do segurado especial migram para o CNIS a partir do sistema de controle de arrecadação do contribuinte individual do INSS, eventuais erros no documento de arrecadação (GPS) causam dano ao trabalhador tanto do ponto de vista da arrecadação - não é a ele imputado o valor do recolhimento no sistema do órgão previdenciário ou é feito com valor menor de contribuição - bem como a informação da sua manutenção no sistema previdenciário e de sua contribuição não chegam ao CNIS, que como dito e repetido, reflete no eventual exercício de um direito social.

Importa realçar que um erro no documento de arrecadação tende a se repetir ao longo do tempo sem que o trabalhador o perceba, pois ele, de praxe, não verifica, não confere os dados constantes na GPS e usualmente entende que, ao pagar a guia, cumpriu sua obrigação e tem direito ao benefício em razão deste adimplemento. Sabe, se muito, que deve guardar seu carnê, e nesse caso o faz religiosamente, mesmo que durante 5 ou 10 anos tenha pago sua contribuição com seu número de identificação errado.

Ao perceber e solicitar retificação do erro, o trabalhador, indiretamente, corrigirá seus dados no CNIS. Porém, tal situação pode reduzir o valor ou mesmo obstaculizar o gozo do benefício previdenciário a que o segurado teria direito.

Em processo de aperfeiçoamento do Cadastro Nacional de Informações Sociais, a DATAPREV, atendendo a demanda do Comitê Gestor, passou por um processo de qualificação da base de dados do CNIS, assim entendida a circularização das informações

\footnotetext{
${ }^{271}$ Conforme Lei de Benefícios:

Art. 15. Mantém a qualidade de segurado, independentemente de contribuições: ....

$\S 3^{\circ}$ Durante os prazos deste artigo, o segurado conserva todos os seus direitos perante a Previdência Social.
} 
armazenadas, através de validação das informações constantes do CNIS, e das enviadas posteriormente, entre os dados dos vários órgãos que compõem o Cadastro Nacional.

Em especial quanto aos dados dos segurados que aqui analisamos, encontramos essa validação no cruzamento das informações apresentadas nos sistemas de Cadastro Pessoa Física (CADPF), alimentado online; na GFIP, que é atualizada diariamente; no Sistema de Acertos dos Recolhimentos do Contribuinte Individual (SARCI), também online; e no Sistema de Retificação de Vínculos e Remunerações (CNISVR), já instalado em 199 Agências da Previdência Social (APS) e ligado em rede com os sistemas centrais do CNIS.

Sem dúvida que esse processo gerencial pode, e cremos que o faz, alterar os dados do trabalhador e retificar dados de recolhimento. Por óbvio, que no caso de retificação para diminuição dos valores de contribuição, o trabalhador deve ser instado a convalidar, documentalmente, os valores incoerentes sob pena de enorme prejuízo ao segurado, passível de indenização por parte da Previdência Social.

\subsubsection{A alteração dos dados pelo próprio trabalhador}

Sendo o Cadastro Nacional de Informações Sociais destinado a implementar o direito dos segurados aos benefícios sociais, dentre estes os previdenciários, sua utilização pelo trabalhador pode se dar a qualquer momento. Logo, esse ao necessitar do socorro da Previdência e se dirigir a uma Agência da Previdência Social (APS), se munido apenas de seu documento de identificação, terá sua garantia pecuniária de renda decorrente da impossibilidade de trabalho imediatamente liberada, desde que todos os seus dados cadastrais, de vínculo e de contribuição, estejam armazenados no CNIS e seja comprovado o fato que enseja o benefício. É dizer, se todas as informações decorrentes de seus vínculos de trabalho estiverem cadastradas, seu benefício previdenciário será concedido somente com a verificação do fato desencadeador desse benefício. Nada mais será necessário e nada será solicitado pelo INSS.

Não cabe outro sentido à inteligência do artigo 29-A da Lei $n^{\circ} 8.213,{ }^{272}$ de 1991 , na redação imposta pela Lei Complementar $n^{\circ} 128$, de 2008. Perfeito, estando tudo perfeito.

\footnotetext{
${ }^{272}$ Lei de Benefícios, art. 29-A: "O INSS utilizará as informações constantes no Cadastro Nacional de Informações Sociais - CNIS sobre os vínculos e as remunerações dos segurados, para fins de cálculo do salário de benefício, comprovação de filiação ao Regime Geral de Previdência Social, tempo de contribuição e relação de emprego."
} 
Patente a presunção legal para a concessão do benefício. Presunção de que todos os dados legalmente exigíveis para que o INSS possa conceder o requerido constam do cadastro criado para esse fim. Possibilidade de prestação de um serviço de excelência, de um gerenciamento do equilíbrio financeiro e atuarial por parte da autarquia previdenciária e mais minimização das possibilidades de fraude, que tanto impactaram a Previdência Social no passado.

Havendo, por outro lado, qualquer discrepância entre os dados cadastrais ou as informações financeiras armazenadas no Cadastro Nacional de Informações Sociais, caberá ao trabalhador solicitar, a qualquer tempo, as alterações. Isso é determinado pela Lei de Benefícios da Previdência Social, que, em seu artigo 29, por meio dos parágrafos $2^{\circ}$ e $3^{\circ}$, contempla a possibilidade de alteração por parte do interessado. Observemos a transcrição dos dispositivos:

\footnotetext{
Art. 29-A: ...

$\S 1^{\circ}$ O INSS terá até 180 (cento e oitenta) dias, contados a partir da solicitação do pedido, para fornecer ao segurado as informações previstas no caput deste artigo.

$\S 2^{\circ} \mathrm{O}$ segurado poderá solicitar, a qualquer momento, a inclusão, exclusão ou retificação de informações constantes do CNIS, com a apresentação de documentos comprobatórios dos dados divergentes, conforme critérios definidos pelo INSS. (grifo nosso)
}

Resta claro que o legislador resguardou o interesse do trabalhador ao permitir o acesso às informações constantes do Cadastro Nacional, e mais, ao possibilitar, mediante comprovação documental - frise-se, por meio de documentos - a alteração dos dados armazenados em nome deste trabalhador.

Em uma visão pragmática, podemos entender ser mais importante a alteração dos dados do que a possibilidade do conhecimento do conteúdo desses, pois se sabe que o trabalhador brasileiro médio dificilmente possui a consciência necessária do exercício de seus direitos previdenciários, a qual se espera de um homem que se acautela para as vicissitudes da vida. Ao reverso, quase sempre imediatista, o trabalhador não tem uma visão previdenciária robusta, vislumbrando o INSS como órgão que concede a aposentadoria, fato distante, necessário somente para o fim de sua vida laboral.

Não obstante os argumentos acima expostos, o que se pretende realçar é a possibilidade da alteração dos dados mediante prova documental. 
Embora se reconheça que a exigência da prova documental possa, por vezes, ser muito onerosa para o trabalhador, uma vez que esta, em regra, fica em posse do empregador, é forçoso compreender que a exigência legal se funda na tutela do próprio sistema de dados e no entendimento de que presunções legais, para serem superadas, necessitam de prova robusta em contrário.

Melhor análise da questão das provas pode ser realizada aos examinarmos quais dados seriam passíveis de alteração, os dados cadastrais e os dados financeiros. Em relação aos primeiros, não há empecilhos que impeçam sua alteração. A informação que se pretende retificar, a constante do CNIS, é inserida com suporte em documento apresentado ao INSS, se o segurado for contribuinte individual, doméstico ou segurado especial, ou o documento que suporta a informação cadastral é apresentado à empresa, nos casos do segurado ser empregado, avulso ou ainda contribuinte individual vinculado à empresa. De toda sorte, esse documento pertence ao trabalhador e contém informações das quais ele necessita a todo momento, as quais ele sabe como obter prontamente em caso de qualquer tipo de necessidade, sendo, portanto, de fácil apresentação no caso de retificação de seus dados no CNIS.

Já em relação à alteração de dados financeiros, de dados atrelados ao vínculo de trabalho, período deste vínculo, ou salário-de-contribuição do segurado, dificuldades podem surgir. O segurado empregado avulso, contribuinte individual ou segurado especial, sendo os últimos vinculados à empresa, se não tiver em sua posse os documentos referentes ao contrato de trabalho, entendido em sentido amplo e não somente como contrato de emprego, pode solicitá-los àquele que tomou seus serviços. Estando este tomador de serviços ainda em atividade, tal tarefa não se torna por demais penosa para o interessado. Em contrapartida, tendo terminado há anos a relação entre o interessado e a empresa, tornam-se diminutas as possibilidades da existência e localização do suporte documental necessário para a comprovação dos dados que se queiram retificar junto ao CNIS.

Parece-nos claro que quanto mais recente o vínculo de trabalho, isto é, quanto menor o tempo transcorrido entre a necessidade do documento em questão e o momento em que se encerrou o vínculo de trabalho, maiores as chances de obtenção dos documentos. De todo modo, duas são as possibilidades da obtenção dos documentos: ou eles estão com o empregado, com o avulso, com o contribuinte individual ou ainda com o 
segurado especial, vinculados à empresa, ou estão com o tomador de serviços do trabalhador.

Diverso é o caso do contribuinte individual que não trabalha para empresa, e do segurado especial que não vendeu sua produção a uma pessoa jurídica. Esses, chamados trabalhadores por conta própria, se não estiverem com a prova documental em seu poder, não terão a quem recorrer. Tal situação se agrava ao recordarmos que o povoamento do CNIS, nestes casos, dá-se por meio das informações constantes do sistema de arrecadação do INSS, ou seja, tudo que abastece o chamado movimento financeiro do segurado se apoia no documento de arrecadação da contribuição previdenciária na GPS. Mera comprovação por "folhinha do carnê da Previdência Social”, como é chamado o impresso do formulário do documento de arrecadação previdenciária vendido nas papelarias de todo país. Eventual perda deste documento poderá causar enorme dificuldade, ou verdadeira impossibilidade, para os segurados mencionados retificarem os dados prejudiciais ao gozo de seus benefícios previdenciários registrados no CNIS.

Por fim, ressalvemos que o segurado doméstico ostenta situação intermediária entre o dito para aqueles segurados que prestam serviços à empresa e aqueles que o fazem por conta própria. Isto porque o doméstico trabalha para outra pessoa física, que pode renovar prova documental. Contudo, não se pode esquecer que o abastecimento de dados do segurado doméstico também é realizado por meio do sistema de controle de arrecadação do INSS, ou seja, por meio das informações constantes da GPS, com todos os problemas acima apontados. Cabível, ainda, quanto ao doméstico, a distinção para aqueles cujos empregadores optaram pelo recolhimento do FGTS e obrigatoriamente o fazem por intermédio da GFIP, como visto alhures

\subsection{Utilização dos dados do trabalhador}

Concebido desde sua tenra origem como fonte de armazenamento de dados sociais do trabalhador, o CNIS passou a ter como objetivo a concessão de benefícios previdenciários, ou melhor, como dissemos em outro ponto, ser a garantia dos direitos trabalhistas e previdenciários dos trabalhadores brasileiros. A utilização de dados do trabalhador se dá nesse sentido. 
Cumprindo o preceito imposto pela Lei $\mathrm{n}^{\circ}$ 8.213, de 1991, no artigo 29-A, acima reproduzido, o Instituto Nacional do Seguro Social, por meio da Instrução Normativa ${ }^{273}$ INSS/PRES $\mathrm{n}^{\circ}$ 45, de 2010, que dispõe sobre a administração de informações dos segurados, o reconhecimento, a manutenção e a revisão de direitos dos beneficiários da Previdência Social e disciplina o processo administrativo no âmbito do INSS, explicita como serão utilizados os dados dos trabalhadores constantes do Cadastro Nacional de Informações Sociais. Observemos as disposições que nos interessam.

A inscrição do segurado na Previdência Social é realizada, segundo o artigo 38 da mencionada $\mathrm{IN} \mathrm{n}^{\circ} 45$, quando a pessoa física é cadastrada no CNIS, mediante informações prestadas dos seus dados pessoais e de outros elementos necessários e úteis à sua caracterização, demonstrando-se desde logo que os dados constantes no Cadastro Nacional de Informações Sociais mediarão o relacionamento entre o INSS e o trabalhador.

Todo o Capítulo II da citada Instrução Normativa, que compreende desde o artigo 47 até o artigo 71, dedica-se à Administração de Informações de Segurados e trata da validade dos dados. Sua clareza de redação merece transcrição:

Art. 47. A partir de 31 de dezembro de 2008 , data da publicação do Decreto $\mathrm{n}^{\circ}$ 6.722, de 30 de dezembro de 2008, os dados constantes do CNIS relativos a vínculos, remunerações e contribuições valem, a qualquer tempo, como prova de filiação à Previdência Social, tempo de contribuiçãa e salários-de-contribuição.

Parágrafo único. Não constando do CNIS informações sobre contribuições ou remunerações, ou havendo dúvida sobre a regularidade do vínculo, motivada por divergências ou insuficiências de dados relativos ao empregador, ao segurado, à natureza do vínculo, ou à procedência da informação, esse vínculo ou o período respectivo somente será confirmado mediante a apresentação pelo segurado da documentação comprobatória solicitada pelo INSS, conforme disposto no art. $48 .{ }^{274}$ (grifo nosso)

Inexorável a disposição normativa. São os dados constantes do Cadastro Nacional de Informações Sociais que valem, observemos bem, são as informações do CNIS que

\footnotetext{
${ }^{273}$ As Instruções Normativas são os atos expedidos pelos órgãos da Administração Púbica encarregados do cumprimento das disposições legais no âmbito das suas competências. Estas instruções explicitam o modo pelo qual o órgão cumprirá e/ou exigirá o cumprimento das disposições legais afetas ao tema normatizado pelo ato. Nesse aspecto, as instruções normativas podem ser vistas como sendo o modo pelo qual a administração interpreta, e portanto, aplica a Lei e o Regulamento. Cf. MEIRELLES, Hely Lopes. Direito Administrativo Brasileiro. 38. ed. São Paulo: Malheiros Editores, 2012. p. 190

274 Podemos observar que o parágrafo único, acima transcrito, trata das questões referentes à eventual necessidade de alteração dos dados armazenados no CNIS, por nós tratados no item anterior.
} 
ostentam validade quanto ao tempo de contribuição, filiação e salários de contribuição dos trabalhadores perante a Previdência Social.

Podemos aqui entender a validade como um atributo de valor, como uma qualidade do ato jurídico de surtir todos os efeitos de sua natureza, emprestando, portanto, toda eficácia àquilo que se quer provar. A Autarquia Previdenciária, por força da IN INSS/Pres $\mathrm{n}^{\circ} 45$, de 2009, assevera que os dados constantes do CNIS são suficientes para sustentar o gozo dos benefícios previdenciários que se perfazem somente com base nesses dados, como, por exemplo, a aposentadoria por tempo de contribuição. ${ }^{275}$

Despiciendo, neste ponto de nosso estudo, maiores ilações sobre a utilização dos dados do CNIS. Já examinamos com riqueza de detalhes o cadastro social. O que nos importa, sem restar a menor dúvida é que, segundo a Lei de Benefícios, segundo o Regulamento da Previdência Social, segundo a Instrução Normativa INSS/PRES n ${ }^{\circ} 4{ }^{276}$ os dados do CNIS devem ser utilizados como prova da filiação, dos vínculos, do tempo de contribuição e do salário de benefício dos trabalhadores.

\subsection{Proteção do CNIS}

Analisaremos neste tópico a proteção do Cadastro Nacional de Informações Sociais do ponto de vista do sistema em si, deixando as questões afetas à tutela do CNIS para o próximo capítulo.

Atualmente, os especialistas em sistemas de informações acautelam-se contra eventuais falhas do próprio sistema (software), problemas das máquinas que processam esses sistemas (hardware), e, especialmente, contra ataques externos ao sistema, aqueles provenientes dos chamados hackers. Ademais, o CNIS também merece proteção no tocante à qualidade dos dados armazenados, ou seja, a confiabilidade desses dados, a adequação deles à realidade do segurado.

Em face do alcance que se pretende para o nosso estudo e a nossa falta de conhecimento técnico sobre a tecnologia da informação, ${ }^{277}$ debruçaremo-nos sobre a segurança das informações do Cadastro Nacional somente no aspecto da qualidade delas,

\footnotetext{
${ }^{275}$ RPS, art. 56, determina que a aposentadoria por tempo de contribuição será devida ao segurado após 35 anos de contribuição se homem, ou trinta anos, se mulher.

${ }^{276}$ Lei de Benefícios, artigo 29-A. RPS, art. 19. IN INSS/PRES n ${ }^{\circ} 45$, art. 47.

${ }^{277}$ Importante mencionar que até o momento de elaboração deste estudo não se tem notícia sobre vazamento de informações ou ataques cibernéticos ao CNIS, o que nos permite emprestar credibilidade, do ponto de vista da tecnologia da informação, ao sistema gerido pela DATAPREV.
} 
ou seja, verificaremos a confiabilidade do sistema como armazenador dos dados do trabalhador necessários para o gozo de seus direitos previdenciários e fundiários.

Desse prisma, encontramos na própria Lei $\mathrm{n}^{\circ}$ 8.213, de 1991, em seu artigo 29-A, já mencionado e transcrito, mais uma presunção, agora quanto à veracidade dos dados informados ao Cadastro Nacional de Informações Sociais. Os parágrafos $3^{\circ}$ e $4^{\circ}$ do artigo $29-\mathrm{A}^{278}$ permitem deduzirmos que os dados inseridos no CNIS são tidos como válidos sempre que temporâneos, isto é, se no prazo previsto em lei a informação for enviada em CNIS, segundo uma das formas previstas. Conforme o dispositivo legal:

Art. 29-A. O INSS utilizará as informações constantes no Cadastro Nacional de Informações Sociais - CNIS sobre os vínculos e as remunerações dos segurados, para fins de cálculo do salário-de-benefício, comprovação de filiação ao Regime Geral de Previdência Social, tempo de contribuição e relação de emprego.

$\ldots$

$\S 3^{0} \mathbf{A}$ aceitação de informações relativas a vínculos e remunerações inseridas extemporaneamente no CNIS, inclusive retificações de informações anteriormente inseridas, fica condicionada à comprovação dos dados ou das divergências apontadas, conforme critérios definidos em regulamento.

$\S 4^{0}$ Considera-se extemporânea a inserção de dados decorrentes de documento inicial ou de retificação de dados anteriormente informados, quando o documento ou a retificação, ou a informação retificadora, forem apresentados após os prazos estabelecidos em regulamento.

$\S 5^{\circ}$ Havendo dúvida sobre a regularidade do vínculo incluído no CNIS e inexistência de informações sobre remunerações e contribuições, o INSS exigirá a apresentação dos documentos que serviram de base à anotação, sob pena de exclusão do período. (grifo nosso)

Inequívoca a presunção legal. Sendo o dado enviado no prazo regulamentar, presume-se válido, pois decorrente de recolhimento, no caso dos segurados que têm seus dados inseridos no sistema em função da arrecadação bancária de sua contribuição; de prestação de informação, no caso de segurados que constam da GFIP emitida pelo tomador de serviços; de gozo de benefício, no caso de segurados que têm suas informações enviadas ao CNIS pelo INSS, realizadas concomitantemente à ocorrência do fato gerador da contribuição previdenciária, ou da dispensa desta, como no caso do recebimento de benefício previdenciário, exceto salário-maternidade. ${ }^{279}$

\footnotetext{
${ }^{278}$ Com a redação dada pela Lei Complementar $n^{\circ} 128$, de 2008.

${ }^{279}$ Os benefícios previdenciários, exceto salário-maternidade, não compõem o salário-de-contribuição dos segurados obrigatórios da Previdência Social, consoante o artigo 28, § 9ª alínea 'a', da Lei de Custeio.
} 
Verificamos, pela leitura do parágrafo $5^{\circ}$ do artigo 29-A da Lei de Benefícios, que, havendo dúvida sobre a informação registrada no CNIS, a Autarquia Previdenciária exigirá a comprovação dessa, sob pena de exclusão da informação do banco de dados sociais. Trata-se do primeiro cuidado da Administração com os dados armazenados do trabalhador. Esse cuidado, obviamente visa ao resguardo do interesse público, ao zelo com o orçamento da Previdência, uma vez que as informações extemporaneamente inseridas provavelmente embasariam concessão indevida de benefícios previdenciários.

Porém, a qualidade da informação não decorre apenas de sua tempestividade. Não é porque prestada no tempo previsto que a notícia enviada sobre o trabalho prestado corresponde ao fato ocorrido. Procedimentos de auditoria sobre a informação devem ser tomados para se assegurar que os dados armazenados no CNIS correspondem ao trabalhador, ao tipo de vínculo que ele ostenta, ao período que prestou o trabalho e, principalmente, à remuneração percebida.

Nesse aspecto, o processo de qualificação das informações busca o cruzamento dos dados que permitam a identificação das extemporaneidades, dos vínculos irregulares, das prevalências, das contribuições fora do padrão, das datas de vínculo superiores às datas de início da própria empresa, dos eventos previdenciários e seus regimes, e da existência e exclusividade de período de atividade rural.

Para que se atinja a almejada qualificação das informações, por meio dos cruzamentos acima descritos, os seguintes sistemas de informações externos e internos do CNIS são cotejados: para efeitos cadastrais, utiliza-se, além de todos os sistemas anteriormente mencionados, o SIRC, com dados dos óbitos e dos registros civis dos trabalhadores, fruto de convênios com os Cartórios de Registro Civil. Além disso, buscouse o aprimoramento do cadastramento dos dados dos segurados especiais, em face da relevância em número de segurados, de sua necessidade do benefício previdenciário, da enorme possibilidade de fraude e do caráter social da medida. Integraram-se dados dos sistemas da Secretaria da Receita Federal do Brasil (CAFIR, base de imóveis), do Ministério do Desenvolvimento Agrário (Programa Nacional do Fortalecimento da Agricultura Familiar - PRONAF), Instituto Nacional de Colonização e Reforma Agrária (INCRA), que se referem aos trabalhadores assentados, dos pescadores, oriundos do Ministério da Pesca e Aquicultura. Incluíram-se também os dados de concessão do segurodesemprego, gerido pelo Ministério do Trabalho e Emprego e pago pela CAIXA, 
fundamental para verificação e gestão da concomitância entre trabalho e percepção do benefício previdenciário destinado a suprir renda quando do desemprego involuntário.

Por fim, buscar-se-á, em breve, a implantação do EFD-Social, sistema digital e online de escrituração da folha de segurados que prestam serviço à empresa. Mais que uma GFIP elaborada na internet, a EFD-S é a escrituração da folha de pagamento de todos os trabalhadores confeccionada mediante requisitos pré-estabelecidos para todo tipo de empresa, com o mesmo layout, com as mesmas informações, e que permitirá a imediata verificação da conformidade dos dados declarados com os efetivamente ocorridos, com evidentes efeitos para a qualidade dos dados informados ao CNIS.

Tais avanços permitirão o maior controle sobre a qualidade das informações constantes do Cadastro Nacional de Informações Sociais, permitindo um gerenciamento cada vez mais eficaz dos benefícios concedidos, a minimização da ocorrência de fraude na concessão desses benefícios e a ampliação da segurança do trabalhador quanto ao acesso ao benefício previdenciário e quanto ao seu valor. Enfim, podemos vislumbrar a evolução tecnológica respaldando direitos sociais. 


\section{CAPÍTULO 7 - EFETIVIDADE DA TUTELA DAS INFORMAÇÕES SOCIAIS}

\subsection{Necessidade de tutela das informações sociais}

Por tutela podemos entender o conjunto de deveres que a lei impõe a uma ou a várias pessoas em benefício e para a guarda e proteção de outras pessoas ou bens. ${ }^{280}$ Dentre os tipos nominados de tutela, encontramos, por exemplo, aquela típica da Administração Pública, à qual a lei imputa o dever de atuação, comumente denominada tutela ex lege ou de ofício. Há a tutela daquele que não tem capacidade para os atos da vida civil, chamada tutela de incapazes. Também existe a tutela jurisdicional, típica das situações nas quais o cidadão se vê obrigado a se socorrer da proteção do Estado para o exercício de seu direito.

O conceito mais apropriado aos propósitos do nosso estudo é o apresentado no Diccionário Básico Jurídico, do qual se depreende que a tutela legal é:

La concedida por la norma consistente en el reconocimiento de derechos, con su haz de facultades y deberes correlativos, atribuyéndoles la protección jurídica necesaria para que se pueda firmar que son derechos. En un primer momento comporta la creación de un derecho subjetivo y, en un segundo momento, el derecho subjetivo puede ser protegido por la tutela jurisdiccional." 281 (grifo nosso)

Após esmiuçarmos o caminho que o Estado brasileiro criou, por meio de lei, para que o trabalhador possa exercer os direitos previdenciários e sociais a ele atribuídos pelo ordenamento jurídico, convém questionar as limitações e alcances da tutela que se pretendeu criar para a defesa do iter, do procedimento que se concebeu para a concretização desses direitos sociais. Seria ela necessária? Se o for, a quem cabe defender esse procedimento de concretização, de acesso e gozo aos benefícios sociais? Por fim, se necessário e devidamente realizado, seria ele suficiente para esta finalidade?

\footnotetext{
${ }^{280}$ ARCO TORRES, Miguel Ángel del; ARCO BLANCO, Ana Isabel del. Diccionário Básico Jurídico. 7. ed, Granada: Comares Editorial, 2009. p.567.

${ }^{281}$ Em tradução livre: "A concedida pela norma e consistente em reconhecimento de direitos, com as faculdades e deveres deles decorrentes, atribuindo-lhes a proteção jurídica necessária que se possa afirmar que são direitos. Em um primeiro momento comporta a criação de um direito subjetivo e, em um segundo momento, o direito subjetivo pode ser protegido pela tutela jurisdicional."
} 
Defendemos que a tutela é necessária, pois ela insurge da constatação, já exaurida neste ponto de nossa pesquisa, de que o exercício dos direitos sociais do trabalhador se encontra apoiado e totalmente fundado no trâmite das informações relativas à realização da atividade laboral. Ademais, não podemos perder de vista que essas advêm do projeto atualmente concebido para concessão, cobrança e gerenciamento do sistema previdenciário, que é, como sabemos, a principal porta de entrada de recursos entregues pela sociedade para financiar a seguridade social.

A esse conjunto de informações necessárias para a implementação dos direitos previdenciários, fundiários e assistenciais do trabalhados chamamos de informações sociais. Mas, não nos esqueçamos, essa massa de dados da vida laboral só é útil ao trabalhador quando armazenada no sistema desenvolvido para a concessão dos benefícios sociais, ou seja, os dados sociais devem ser conhecidos do Estado, para que ele entregue as prestações devidas.

Voltando à definição de tutela legal acima esposada, podemos asseverar que temos, sim, no sistema de informações sociais brasileiro, tutela legal. Tal afirmação decorre de simples leitura da Lei de Custeio, mais precisamente dos artigos 32 e 32-A da Lei $\mathrm{n}^{\circ} 8.212$, de 1991, com a redação dada pela Lei ${ }^{\circ} 11.941$, de 2009, pois há um conjunto de deveres que a lei impôs a algumas pessoas, consoante a definição que adotamos acima.

Claro está que, uma vez existindo tutela legal das informações sociais, ela se faz necessária. Resta saber se comporta, efetivamente, a criação de um direito subjetivo.

\subsection{Quais informações devem ser tuteladas}

Temos assentado que o exercício dos direitos sociais do trabalhador brasileiro está lastreado no conhecimento das informações cadastrais e laborais do trabalhador brasileiro pela Autarquia Previdenciária. Vimos quais os veículos que transportam essas informações, sendo o principal deles, a GFIP.

No capítulo 5, verificamos a dupla natureza jurídica da GFIP, que, de um lado, é típica obrigação tributária acessória, pois decorre de lei tributária, e é obrigação positiva, isto é, obrigação de fazer, no sentido de prestar informações que permitam ao Fisco arrecadar e fiscalizar as contribuições previdenciárias devidas pelo contribuinte. Por outro lado, observado na ótica da disposição da Lei $\mathrm{n}^{\circ}$ 8.213, trata-se de obrigação legal, em virtude dos dados sociais, laborais e previdenciários dos trabalhadores nela elencados, os 
quais permitem ao INSS a concessão e o cálculo dos benefícios dos trabalhadores. Desse modo, dois grandes grupos de informações que constam da GFIP necessitam de tutela: os tributários e os sociais. Recordando o capítulo 4, quando esmiuçamos a Guia de Informações, observamos que a mesma informação pode apresentar, simultaneamente, interesse tributário e social, como por exemplo, a remuneração do trabalhador. A determinação do quantum percebido pelo cidadão, decorrente da prestação de serviço que realizou, interessa ao Fisco, pois é base de cálculo da contribuição previdenciária incidente sobre a folha de pagamento. Também interessa ao próprio trabalhador, pois o valor da remuneração deverá integrar o conjunto de informações referentes ao segurado, enviado naquele mês ao CNIS, uma vez que o valor percebido será base para o cálculo de eventual salário-de-benefício, se o exercício de algum direito previdenciário se fizer necessário.

O singelo exemplo nos permite uma extrapolação: as informações relativas ao desenvolvimento do trabalho pela pessoa física apresentam relevância tanto tributária quanto social. O custeio da Seguridade Social, segundo o artigo 195 da Constituição Federal, será suportado por toda sociedade, de forma direta e indireta, mediante recursos provenientes da União, dos Estados, do Distrito Federal e dos Municípios, e das contribuições sociais, elencadas em seus quatro incisos. Uma das contribuições ali elencadas, a incidente sobre o trabalho remunerado, consta em dois incisos: no inciso I, alínea 'a', a cargo do tomador do trabalho da pessoa física; e seu reflexo, a constante do inciso II, que deve ser suportada pelo próprio trabalhador remunerado. Vemos assim que o trabalho remunerado da pessoa física é, portanto, fato gerador de contribuição previdenciária.

Alguns doutrinadores do Direito Tributário, ${ }^{282}$ ao refletirem sobre esse fato gerador afeto a dois sujeitos passivos, entendem que a contribuição social previdenciária tem características típicas de imposto para a empresa, que a paga sem nenhuma contrapartida. Porém, para o trabalhador, a contribuição previdenciária tem natureza tributária típica de taxa, uma vez que corresponde para ele, como sujeito passivo, a uma contraprestação de serviço público, pois o trabalhador, ao contribuir, terá direito aos benefícios previdenciários instituídos na lei.

Essa visão nos ajuda a compreender a extrapolação de raciocínio acima apresentada. Uma informação social vinculada ao trabalho remunerado desenvolvido em

${ }^{282}$ Cf. CARVALHO, Paulo de Barros. Curso de direito tributário. 19. ed. São Paulo: Saraiva, 2007. p.43. e GAMA, Tácio Lacerda. Contribuição de Intervenção no Domínio Econômico. São Paulo: Quartier Latin, 2003. p 103. 
dado mês por determinado trabalhador para determinada empresa importa tanto para a Receita Federal do Brasil, que vê nessa informação a notícia da ocorrência de um fato gerador tributário, quanto para o INSS, que por causa da contribuição social suportada pelo trabalhador, passou a ter que prever um ônus previdenciário futuro e incerto.

Firmemos um conceito: as informações relacionadas ao trabalho desenvolvido pela pessoa física devem ser tuteladas por serem de interesse do Fisco e também por serem necessárias à Autarquia Previdenciária. Não olvidemos, contudo, que existem informações que interessam somente ao INSS, que povoam o CNIS somente para efeitos previdenciários, pois são desprovidas de encargos tributários, como ocorre, por exemplo, se um trabalhador tiver no gozo de algum benefício previdenciário durante $o$ desenvolvimento de seu trabalho. Essa informação, por óbvio, ostenta interesse somente social, o que - definitivamente - não exime a necessidade de protegê-la.

Logo, as informações decorrentes da relação trabalhista, qualquer que seja o vínculo pelo qual o trabalho é prestado, necessitam de proteção, seja pela importância tributária que delas decorre, seja pela relevância social que ostentam. Tal proteção também deve ser emprestada à informação que tenha somente cunho social, não obstante a falta de interesse tributário que ela possui.

Necessário sublinharmos que tutelar a informação é proteger não só seu conteúdo, mas, principalmente na ótica desenvolvida no presente estudo, garantir o acesso dos interessados, ou seja, permitir sempre que a informação chegue ao destinatário, no nosso caso, ao Cadastro Nacional de Informações Sociais.

\subsection{Meios de tutela hoje existentes}

A tutela das informações sociais decorre, como apontado, de expressa previsão legal. Encontramos na Lei $\mathrm{n}^{\circ}$ 8.212, de 1991, a proteção que o legislador entendeu apropriada para a informação social que a empresa, ou o a ela equiparado, deve prestar.

Houve, ao longo dos anos, alteração na proteção que a Lei de Custeio da Previdência entendeu adequada às informações que embasam a concessão de benefícios previdenciários e que, para tanto, abastecem o CNIS. É essa alteração, perniciosa em nosso entendimento, que pretendemos estudar. Para tanto, é necessária a análise da evolução do texto legal ao longo do tempo. 
Em 1997, a Lei $\mathrm{n}^{\circ} 8.212$ foi aletrada pela Lei ${ }^{\circ}$ 9.528, a qual introduziu o inciso IV ao artigo 32 e impôs o dever à empresa, ou ao seu equiparado, de informar mensalmente ao INSS dados relacionados aos fatos geradores de contribuição previdenciária e outras informações de interesse da Autarquia, por intermédio de documento definido em regulamento. Alguns dispositivos previstos na lei continham procedimentos que demonstravam a preocupação com a veracidade das informações e outros dispositivos cominavam sanções no caso de descumprimento do dever de informação, ou no caso de informação incorreta ou parcial.

Iniciemos com uma concepção interessante do legislador, que, saliente-se, foi vetada. Em 2002, a Lei $n^{\circ} 10.403$, que alterou diversos artigos e da Lei de Custeio, previu a inclusão de um inciso V no mencionado artigo 32 da Lei de Custeio, no qual se lê que o empregador deve "encaminhar as informações do inciso IV ao sindicato representativo da categoria profissional de seus empregados, mediante requisição deste.” Destaquemos que sua redação prevê um procedimento com nítido viés de proteção da informação prestada pelo empregador, pois determina que este envie, quando solicitado, cópia da GFIP ao sindicato representativo dos trabalhadores. Ora, a que título o legislador concebeu tal procedimento?

Por certo estava tutelando as informações prestadas pelo empregador, outorgando ao sindicato representativo da categoria profissional que representava os trabalhadores daquele empregador, o controle da veracidade das informações constantes na GFIP enviada. O sindicato poderia verificar se todos os seus filiados constavam do documento, se os salários informados correspondiam à realidade, se todas as rubricas remuneratórias estavam consideradas como base de cálculo das contribuições fundiárias e previdenciárias, se o piso normativo, e demais cláusulas remuneratórias do contrato coletivo estavam sendo respeitados etc.

Não há como se afastar dessa conclusão. Haveria uma tutela das informações constantes na GFIP quando se permitisse que terceiro interessado tivesse acesso ao conteúdo dos dados enviados ao CNIS. E não há como se entender que o sindicato dos trabalhadores não é um terceiro interessado na implementação dos direitos sociais dos seus filiados, ${ }^{283}$ uma vez que é ator social de suma importância na vida laboral dos trabalhadores, consoante o disposto no artigo $8^{\circ}$, inciso III, da Carta de $1988 .^{284}$

283 Cf. SILVA, Homero Batista Mateus da. Curso de Direito do Trabalho Aplicado. vol. 07. Rio de Janeiro: Elsevier, 2009. p.24.

${ }^{284}$ Constituição Federal, Art. $8^{\text {o: }}$ "É livre a associação profissional ou sindical, observado o seguinte: 
A proteção pretendida com o inciso $\mathrm{V}$ acima discutido seria obtida por meio da capacidade do sindicato de pressionar o empregador, ou as autoridades constituídas, no sentido da eventual correção das informações prestadas, pois, de fato, não há como o ator social coagir a empresa ao cumprimento de sua obrigação. Podemos até entender que a tutela dos dados sociais se daria pela publicização de seu conteúdo, pelo conhecimento por outros agentes desses dados e, a partir desse conhecimento, pela verificação da conformidade deste conteúdo.

Cremos que, do ponto de vista de controle, a previsão do inciso V do artigo 32 da Lei de Custeio se mostrava, no mínimo, interessante, e, partindo-se da premissa de um sindicato atuante, efetiva, já que se pode imaginar, sem muito otimismo, que a entidade dos trabalhadores atuaria no sentido de cobrar da empresa a apresentação tempestiva da GFIP corretamente preenchida, e no caso de inadimplemento, o sindicato notificaria as autoridades competentes sobre esse inadimplemento.

Não obstante toda a lógica protecionista das informações sociais acima apresentada, com a inegável vantagem do engajamento sindical, o que por certo reforça o aspecto social da Guia de Informações do FGTS e da Previdência Social e o conceito de cidadania tão mitigado nas relações de trabalho existentes no Brasil, houve por bem o Sr. Fernando Henrique Cardoso, no exercício da Presidência da República, vetar o inciso V, com base no exposto na mensagem de veto abaixo transcrita:

\begin{abstract}
A proposta de criar a obrigação para as empresas encaminharem as informações de que trata o inciso IV do art. 32 da Lei no 8.212, de 1991, aos sindicatos representativos da categoria é desnecessária e não atende ao interesse público.

A Resolução n- 321, do Conselho Curador do Fundo de Garantia do Tempo de Serviço, já estabelece a obrigação do agente operador do respectivo fundo de fornecer, às entidades sindicais, as informações relativas aos seus filiados constante na Guia de Recolhimento do Fundo de Garantia do Tempo de Serviço e de Informações à Previdência Social - GFIP. Neste documento já constam todas as informações pertinentes que podem vir a interessar aos sindicatos representativos das categorias dos empregados.

Desta forma, se estas informações já podem ser fornecidas pela Caixa Econômica Federal não há necessidade de obrigar as empresas a fornecerem a mesma informação aos respectivos sindicatos.

Por outro lado, a redação proposta autoriza que os sindicatos possam requerer todas as informações que interessam ao INSS, tais como os
\end{abstract}

III - ao sindicato cabe a defesa dos direitos e interesses coletivos ou individuais da categoria, inclusive em questões judiciais ou administrativas; 
salários-de-contribuição dos contribuintes individuais, o que nos parece uma extrapolação da finalidade que visa atingir a citada obrigação, qual seja, a de colocar os sindicatos a serviço da defesa dos interesses dos seus filiados. A remuneração dos contribuintes individuais - autônomos, empresários etc - não interessa aos sindicatos representativos dos empregados, pelo que a obrigação que se pretende criar pelo dispositivo, além de criar constrangimentos a estes segurados, viola a intimidade e a vida privada destes cidadãos, nos termos do art. 50, inciso X da Constituição Federal. ${ }^{285}$ (grifo nosso)

Embora importantíssima, a tutela das informações por intermédio do sindicato pode ser considerada de fraca intensidade, porque não há constrangimento do obrigado pela lei ao cumprimento do dever de prestar informações. E deveres legais, se inadimplidos, devem ser sancionados. ${ }^{286}$

Ciente da necessidade e importância de uma tutela provida de maior efetividade, o legislador andou bem na proteção do conteúdo do documento que a Lei ${ }^{\circ} 9.528$ criava. Introduziu cinco parágrafos no inciso IV do artigo 32 da Lei $\mathrm{n}^{\circ} 8.212$, com o fito de proteger as informações prestadas na GFIP e de proteger a própria GFIP. Analisemos um a um.

O primeiro conteúdo protetivo se observa no parágrafo $4^{\circ}$ do inciso IV do artigo 32 da Lei de Custeio:

$\S 4^{\circ}$ A não apresentação do documento previsto no inciso IV, independentemente do recolhimento da contribuição, sujeitará o infrator à pena administrativa correspondente a multa variável equivalente a um multiplicador sobre o valor mínimo previsto no art. 92, em função do número de segurados, conforme quadro abaixo:

\begin{tabular}{|l|l|}
\hline 0 a 5 segurados & $1 / 2$ valor mínimo \\
\hline 6 a 15 segurados & 1 x o valor mínimo \\
\hline 16 a 50 segurados & 2 x o valor mínimo \\
\hline 51 a 100 segurados & 5 x o valor mínimo \\
\hline 101 a 500 segurados & 10 x o valor mínimo \\
\hline 501 a 1000 segurados & 20 x o valor mínimo \\
\hline 1001 a 5000 segurados & 35 x o valor mínimo \\
\hline acima de 5000 segurados & 50 x o valor mínimo \\
\hline
\end{tabular}

285 Disponível em: <http://www.planalto.gov.br/ccivil_03/Leis/Mensagem_Veto/2002/Mv018-02.htm>. Acesso em: 14 nov. 2012.

286 “As infrações são absorvidas pela norma jurídica através da aplicação de sanções aos infratores e estas são as mais diversas." Cf. COELHO, Sacha Calmon Navarro. Sanções Administrativas Tributárias. in MACHADO, Hugo de Brito (org). Sanções Administrativas Tributárias. São Paulo: Dialética, 2004. p. 422. 
Observemos com atenção a disposição do transcrito parágrafo $4^{\circ}$. Trata-se de proteção, por meio de sanção, ao cumprimento da obrigação de informar. Em outros termos, a lei impõe, clara e precisamente, o dever de entregar o documento que é o veículo das informações sociais e a tutela que o parágrafo $4^{\circ}$ é a garantia do dever de prestar informações. Ademais, imputa pena pelo descumprimento do dever de informar. Se não, por que a dicção: "A não apresentação do documento previsto no inciso IV, independentemente do recolhimento da contribuição, sujeitará o infrator à pena"? Da leitura do dispositivo, constatamos que o interesse protegido pela sanção legal é o da informação, uma vez que há pena mesmo que o tributo devido tenha sido recolhido. Tal demonstração de interesse decorre da dupla natureza da GFIP, de obrigação tributária acessória e obrigação social e realça, sem deixar dúvida, a importância das informações sociais, pois há pena mesmo que com cumprimento da obrigação tributária principal, o que em regra, mitiga a falha na prestação das informações fiscais. Essa multa, convém ressaltar, é calculada com base no número de segurados que deixaram de ter seus dados sociais enviados ao INSS, de modo que existe perfeita conjugação do interesse protegido e da falta cometida.

Nesse aspecto, como sempre observamos em nossa atuação profissional, ${ }^{287}$ surge um efeito de conscientização do obrigado, pois, mesmo que autuado, ele compreende o porquê da sanção aplicada. Por ser, no mais das vezes, favorecido pelo exato cumprimento da obrigação, por ser trabalhador, o encarregado do preenchimento do complexo documento de informações se aperfeiçoa e passa a cumprir a obrigação de maneira consciente e precisa.

Em conclusão de nossa análise do parágrafo $4^{\circ}$, podemos afirmar que se tratava de tutela legal eficaz, pois conforme assentamos alhures, garantiria “...en un primer momento ... la creación de un derecho subjetivo", ${ }^{288}$ uma vez que a informação social chegaria ao CNIS.

Vejamos agora as disposições do parágrafo $5^{\circ}$ do inciso IV do artigo 32 da Lei $\mathrm{n}^{\circ}$ 8.212:

\footnotetext{
${ }^{287}$ Como Auditores Fiscais da Receita Previdenciária, verificávamos, à época da vigência do dispositivo legal comentado, que todas as autuações efetuadas com base nesse fundamento eram facilmente compreendidas pelo sujeito passivo em face da adequação entre a falta cometida e a pena aplicada.

${ }^{288}$ Excerto da citação de Arco Torres feita linhas atrás. (Cf ARCO TORRES, Miguel Ángel del; ARCO BLANCO, Ana Isabel del. Diccionário Básico Jurídico. 7. ed, Granada: Comares Editorial, 2009. p.567)
} 
$\S 5^{\circ}$ A apresentação do documento com dados não correspondentes aos fatos geradores sujeitará o infrator à pena administrativa correspondente à multa de cem por cento do valor devido relativo à contribuição não declarada, limitada aos valores previstos no parágrafo anterior. (grifo nosso)

Aqui sim, encontramos a pena específica para as informações tributárias. É no parágrafo $5^{\circ}$ que o legislador explicitou e protegeu o caráter de obrigação acessória tributária da GFIP.

A sonegação de informações dos fatos geradores é protegida ao sancionar o obrigado que, embora apresente o documento de informações fiscais, fundiárias e previdenciárias, o faz com divergência dos fatos geradores efetivamente ocorridos, diminuindo-os. Tal conduta leva à penalidade equivalente à própria tributação incidente sobre o fato gerador cuja ocorrência não se informou, pois a pena administrativa prevista no texto legal determina que a apresentação do documento com dados não correspondentes aos fatos geradores sujeita o infrator à multa de $100 \%$ do valor devido relativo à contribuição não declarada. Porém, tal multa sofreria a limitação equivalente ao valor previsto no parágrafo $4^{\circ}$, acima reproduzido.

Interessante essa disposição legal, que limita a pena pecuniária pelo descumprimento de obrigação tributária a valor previsto em norma com nítido alcance social, pela relevância das informações que tutela. Preferimos, com todo respeito à opinião contrária, entender que o legislador sinaliza no sentido da maior proteção do caráter social da GFIP.

De todo modo, há efetividade na proteção dos dados de interesse do Fisco e, por que não dizer, do FGTS, veiculados por meio da GFIP. Novamente cabem elogios ao legislador.

Passando à análise do parágrafo $6^{\circ}$, do mesmo inciso IV do artigo 32 , encontramos a seguinte determinação:

$\S 6^{\circ} \mathrm{A}$ apresentação do documento com erro de preenchimento nos dados não relacionados aos fatos geradores sujeitará o infrator à pena administrativa de cinco por cento do valor mínimo previsto no art. 92, por campo com informações inexatas, incompletas ou omissas, limitadas aos valores previstos no $\S 4^{\circ}$. (grifo nosso)

Nesse ponto, maximiza-se a intenção do legislador em proteger as informações sociais constantes da GFIP, ao prever sanção por campo que contenha informação de 
interesse social diversa da realidade. Todo tipo de informação que não seja afeta aos fatos geradores tributários, que divirja dos dados efetivos do trabalhador e do seu vínculo, ou qualquer outro que não se relacione com sua remuneração ou parcela dessa, ou mesmo dado do empregador que não implique valoração da tributação que se apresentar com inexatidão, de maneira incompleta ou que não conste da GFIP, será passível de pena pecuniária. Há, assim, efetiva tutela das informações constantes da GFIP. De todas as informações que não são relacionadas com a ocorrência dos fatos geradores tributários, até porque esses, como visto, estão protegidos por outro dispositivo legal, no caso o previsto no parágrafo $5^{\circ}$.

Em um passo adiante, encontramos o legislador demonstrando que entende importante o adimplemento, mas, que no caso de mora, essa deve ser rapidamente purgada. Apontando para a relevância da informação correta e o mais tempestiva possível, a Lei $\mathrm{n}^{\circ}$ 8.212 , por meio do parágrafo $7^{\circ}$, preceitua:

$\S 7^{\circ}$ A multa de que trata $\mathrm{o} \S \mathbf{4}^{\circ}$ sofrerá acréscimo de cinco por cento por mês calendário ou fração, a partir do mês seguinte àquele em que o documento deveria ter sido entregue. (grifo nosso)

Faz todo sentido aumentar a sanção quanto maior o atraso na prestação da informação quando se sabe que a utilidade da informação que se pretende obter é a de permitir agilidade tanto na cobrança das contribuições sociais, como visto principal fonte de custeio do sistema de seguridade social, quanto da concessão dos benefícios previdenciários. Vê-se que a informação tempestiva corretamente prestada alimenta as duas pontas do sistema previdenciário brasileiro, pois permite o gerenciamento dos créditos garantidores do financiamento dos benefícios e o controle dos débitos, dos pagamentos dos benefícios aos trabalhadores que deles necessitam. Inegável, portanto, que a tutela pelo adimplemento tempestivo do dever de prestar informação protege o sistema concebido, que se realiza por meio da entrega da Guia de Informações do FGTS e da Previdência Social. Tal conclusão valida a existência do parágrafo $7^{\circ}$ como típica multa moratória. $^{289}$

Por fim, observamos que o parágrafo $9^{\circ}$ explicita a obrigatoriedade da prestação de informações mesmo na competência em que não ocorra fato gerador de contribuição previdenciária:

${ }^{289}$ Cf. PEREIRA, Caio Mário da Silva. Instituições de Direito Civil. vol. II. 24. ed. Rio de Janeiro: Ed. Forense, 2011. p. 148. 
$\S 9^{\circ} \mathbf{A}$ empresa deverá apresentar o documento a que se refere o inciso IV, mesmo quando não ocorrerem fatos geradores de contribuição previdenciária, sob pena da multa prevista no $\S 4^{\circ}$. (grifo nosso)

Tal disposição se coaduna com a lógica do sistema. Se determinada empresa, ou equiparado, não remunerou nenhuma pessoa física, não contratou nenhuma cooperativa de trabalho, não prestou serviços mediante cessão de mão-de-obra, e nem adquiriu produto rural de pessoa física, tais fatos devem ser notificados ao Fisco, pois são excepcionais na vida da contribuinte e denotam que ele não exerceu nenhuma atividade produtiva que se utilize de mão-de-obra, posto que nenhum fato gerador de contribuição previdenciária ocorreu. Claro que sempre há a possibilidade da terceirização das atividades produtivas para outra pessoa jurídica realizá-las, mas, mesmo que por dedução, o Fisco deve ser informado da situação.

Embora sem ocorrência de nenhum fato gerador, a GFIP pode vir a conter informação relevante, só que eminentemente social, como no caso de determinada empresa que na competência não tenha incorrido em nenhum fato gerador, mas que possua um empregado no gozo de um dado benefício previdenciário, por exemplo, auxílio-doença. Essa situação deve ser informada e é relevante para o CNIS, pois, mesmo sem remuneração, sem contribuição portanto, o trabalhador afastado continua ostentando a condição de segurado obrigatório e tendo seu tempo de contribuição contado para os demais benefícios previdenciários, por exemplo, aposentadoria por tempo de contribuição.

Depois de analisarmos toda a proteção imposta pela Lei $n^{\circ} 9.528$, de 1997, que alterou a redação da Lei $\mathrm{n}^{\circ}$ 8.212, incluindo o inciso IV no artigo 32, podemos concluir que o sistema idealizado para permitir o gerenciamento do custeio e da concessão de benefício da Previdência Social apresentava um grau de tutela adequado, passível até de algum aperfeiçoamento, mas que em seu todo é coerente e efetivo, além de indicar os bens que efetivamente pretendia proteger.

Tais tutelas constantes da Lei de Custeio, conforme já avaliamos, ${ }^{290}$ apresentavam uma característica de suma importância para a efetividade da proteção do Cadastro Nacional de Informações Sociais. Essa característica é ímpar no sistema tributário, tão

\footnotetext{
${ }^{290}$ No item 5.4.1 ao estudarmos a sanção pela não entrega da GFIP tangenciamos a questão da relevação da multa prevista pelo regulamento da Previdência Social.
} 
distinta, que, no esteio da unificação dos Fiscos Federais, ${ }^{291}$ fazia a disposição chocar-se frontalmente com o dogma da espontaneidade, ${ }^{292}$ como se poderá entender.

O Regulamento da Previdência Social, aprovado pelo Decreto n 3.048, de 1999, ao tratar das condições agravantes ou atenuantes das penalidades, dispunha em seu artigo 291:

\begin{abstract}
Art. 291. Constitui circunstância atenuante da penalidade aplicada ter o infrator corrigido a falta até a decisão da autoridade julgadora competente.

$\S 1^{\circ} \mathrm{A}$ multa será relevada, mediante pedido dentro do prazo de defesa, ainda que não contestada a infração, se o infrator for primário, tiver corrigido a falta e não tiver ocorrido nenhuma circunstância agravante. (grifo nosso)
\end{abstract}

Pode-se deduzir, para os fins que nos interessam, que a empresa, ou o a ela equiparado, tendo sido autuada por qualquer das razões previstas na Lei ${ }^{\circ}$ 8.212, de 1991, quanto ao cumprimento da obrigação de prestar informações por meio da GFIP, se corrigisse de maneira eficaz a infração dentro do prazo de defesa e requeresse a relevação da multa, em sendo primário, teria deferimento a esse pedido, ou seja, nada pagaria a título de pena administrativa.

O artigo 291, infelizmente revogado, permitia, em face da sua disposição no sentido do arrependimento eficaz, a maior das tutelas que as informações sociais do trabalhador poderiam obter. Tal afirmação decorre de uma constatação lógica. O legislador cria um sistema baseado na tecnologia da informação, pelo qual poderá gerenciar não só o ingresso de recursos no sistema previdenciário como também todos os pagamentos de benefícios sociais devidos. Além do gerenciamento, a própria concessão dos benefícios se torna mais ágil, verificável, segura contra fraudes, e principalmente, paga nos exatos valores devidos ao segurado, tudo isso baseado em um sistema que necessita que as informações do trabalhador, do contrato de trabalho e do empregador estejam corretas e sejam prestadas de maneira tempestiva.

Ora, ao imaginar que a GFIP, tal qual estudamos no capítulo 4, foi concebida como um documento que contém todos os dados relativos ao trabalhador, tem flexibilidade para receber as informações de todos os tipos de contrato de trabalho e as remunerações legalmente previstos, e ainda permite que o empregador informe todos os fatos geradores

\footnotetext{
${ }^{291}$ Ver nota de rodapé 101, página 57.

${ }^{292}$ Nos termos do art.138 do CTN, atribui-se espontaneidade ao contribuinte quando este, antes de iniciado qualquer procedimento administrativo ou medida de fiscalização, retifica a informação prestada e recolhe o tributo devido. Nestes casos, não há cobrança de multa tributária, somente juros de mora e multa moratória, assim entendida aquela devida por atraso no recolhimento.
} 
de contribuição previdenciária nos quais incidiu, o INSS passa a necessitar que a Guia de Informações seja correta e tempestivamente preenchida. Logo, quando os obrigados à prestação de informações se desvencilham do dever legal de maneira escorreita, todo o sistema se aperfeiçoa no sentido desejado pela Autarquia Previdenciária e pelo Fisco Federal. É dizer: há o adimplemento da obrigação, há o abastecimento dos dados sociais no CNIS. Em sentido contrário, se não houver o cumprimento do dever de informar, e por se tratar de uma obrigação legal, não resta outra atitude ao Estado senão a de punir o obrigado pelo descumprimento da lei.

Aqui o ponto que desejamos discutir. O que se deseja, o que persegue o interesse público não é a pena pelo descumprimento, isto é, não se quer apenas a punição do infrator para que este, sendo sancionado pela falta de observância do dever legal, não mais o transgrida. Ao reverso, o que se quer é que ele, tendo por lei uma obrigação de fazer, realize-a, cumpra-a de maneira a tornar eficaz todo o sistema de informações sociais, consoante concebido pelo INSS. Justamente por isso a efetividade da tutela legal é maximizada quando o sistema de sanção consegue que a empresa inadimplente reverta esse seu descumprimento, reenviando as informações de maneira correta, mesmo que tardia.

Portanto, uma sanção custosa, como as penas administrativas impostas pelo diversos parágrafos do inciso IV do artigo 32 da Lei de Custeio, é, indubitavelmente, um desencorajador ao descumprimento do dever de informar. Porém, se esse dever não for cumprido, ou cumprido de forma inexata, a melhor proteção que o sistema de punição pode realizar é forçar o cumprimento da prestação da informação ou correção dessa informação para que o Cadastro Nacional de Informações Sociais seja devidamente abastecido. Era exatamente o efeito que a relevação da multa, desde que houve o correto envio da GFIP, obtinha. O perdão da pena administrativa, diante do arrependimento eficaz - assim entendido a exata prestação das informações devidas - tinha o condão de reajustar o sistema, aperfeiçoando-o após a falha cometida pela empresa, diante da ação do Auditor Fiscal da Receita Federal do Brasil.

Plena efetividade da tutela legal, que, exemplo máximo da lógica dos efeitos perversos, ocorre quando do perdão de uma multa já aplicada! E mais, a própria atuação, o próprio agir do Fisco favorece a correção da infração, pois os normativos da época determinavam que o Auditor Fiscal anexasse ao Auto de Infração um arquivo magnético contendo todos os dados que deveriam constar da GFIP e que não foram informados pela empresa. Como a empresa recebia uma cópia do auto de infração e, portanto, do anexo em 
arquivo magnético, cabia a ela somente copiar esse arquivo para o sistema da GFIP, denominado SEFIP, e enviar à Caixa, porta de entrada dos dados do CNIS. Ao agir assim, corrigia eficazmente a falta, e teria direito a relevação da multa, desde cumpridos os outros requisitos constantes do RPS.

Podemos agora entender porque, linhas acima, dissemos que o sistema previsto pelo Regulamento da Previdência Social colidia com o dogma da denúncia espontânea. O contribuinte usava o próprio trabalho do agente fiscal para nada pagar pelo descumprimento do dever legal. A Lei $\mathrm{n}^{\circ} 11.941$, de 2009, reformulou todo o inciso IV do artigo 32 da Lei $\mathrm{n}^{\circ}$ 8.212, de 1991, e introduziu o artigo 32-A, que passou a disciplinar a sanção pelo descumprimento da obrigação tributária acessória representada pela entrega da GFIP. Mera pena pecuniária.

Não nos cansamos de repetir: tal alteração legal demonstra que o legislador atribui uma tutela maior ao caráter de obrigação tributária da GFIP do que à sua característica social. Olvidou-se de que essa função de veículo garantidor dos direitos sociais dos trabalhadores não encontra paralelo hoje, nem no sistema social, nem no sistema jurídico. Nesse sentido, hodiernamente, não há previsão para que a informação sonegada pela não entrega, ou entrega inexata da GFIP, seja envidada ao CNIS, exceto pelo próprio interessado, o trabalhador brasileiro, que convenhamos, ao considerarmos o cidadão médio, infelizmente, não possui discernimento para tanto.

Tecemos maiores considerações sobre as penas administrativas afetas à Guia de Informações ao FGTS e à Previdência Social, hoje vigentes, no capítulo 5, item 5.4.

\subsection{Efetividade da proteção}

Cientes de que o dever de informar os dados dos trabalhadores em serviço em determinada competência por meio da GFIP é, consoante a teoria geral das obrigações, uma obrigação de fazer, analisemos quais meios de proteção trariam maior efetividade.

O preenchimento da GFIP, conforme discutido no capítulo 5, atende ao cumprimento de uma disposição de lei, com nítido caráter tributário, de um turno, e ao cumprimento de obrigação de fazer, de outro, observado pelo cunho social do documento de informações. $O$ aspecto tributário, a obrigação acessória, tem relevância até o cumprimento da obrigação tributária principal, ou seja, até o pagamento do tributo devido e declarado no documento. Extinto o crédito pelo pagamento, a obrigação acessória perde 
o seu sentido e deixa de ter finalidade, pois, conforme estatuído no $\mathrm{CTN}^{293}$ essa existe no interesse da arrecadação ou da fiscalização dos tributos. Extinta a obrigação principal que surgiu pela ocorrência do fato gerador e se extingue com o pagamento do tributo, por certo o interesse da arrecadação ou da fiscalização se perfez. ${ }^{294}$

Assim, no aspecto tributário, a efetividade da proteção da GFIP se obtém por meio de uma pena de tal monta que sua existência leve o contribuinte ao adimplemento da obrigação acessória para não incidir na sanção pecuniária prevista.

As disposições da Lei ${ }^{\circ}$ 8.212, de 1991, constantes dos artigos 32, 32-A e 35-A, ${ }^{295}$ atingem a proteção almejada quando se analisa a GFIP somente como obrigação tributária acessória, uma vez que estabelece multa pecuniária nos casos de lançamento de ofício de contribuição cujo valor não foi declarado ou declarado de forma inexata no documento. Aliada ao acréscimo no valor do tributo não pago e não declarado, há ainda a multa típica da ausência de informações constante dos mencionados artigos 32 e 32-A, estas de pequena monta, sem dúvida.

Desnecessárias, até por já terem sido discutidas no item 5.4, maiores considerações quanto à efetividade do caráter tributário da GFIP. Desse modo, passaremos a tratar da efetividade da proteção do viés social do documento.

Convencidos da praticidade, operacionalidade, segurança e justiça do sistema de concessão de benefícios concebido a partir da criação do Cadastro Nacional de Informações Sociais, entendemos que a efetividade da tutela dos direitos do trabalhador brasileiro se dá na medida da proteção do sistema tal qual concebido, e nesse diapasão, na proteção da inserção dos dados no CNIS, que se dá, como forma mais importante em face do volume das informações que transmite e da quantidade de segurados que abrange, por intermédio da GFIP. Logo, ao proteger a Guia de Informações, na verdade, ao garantir o cumprimento do dever de prestar as informações sociais, tutela-se o Cadastro Nacional de Informações Sociais e, por meio dele, garante-se o acesso do trabalhador aos benefícios sociais previstos no ordenamento.

\footnotetext{
${ }^{293}$ Art. 113, § 2 , do Código Tributário Nacional.

${ }^{294}$ Cf. PAULSEN, Leandro. Direito Tributário: Constituição e Código Tributário à Luz da Doutrina e da Jurisprudência. Porto Alegre: Livraria do Advogado, 2009. p.900.

${ }^{295}$ Lei de Custeio, Art. 35-A. "Nos casos de lançamento de ofício relativo às contribuições referidas no art. 35 desta Lei, aplica-se o disposto no art. 44 da Lei no 9.430, de 27 de dezembro de 1996:"

Lei $\mathrm{n}^{\circ}$ 9.430: "Art. 44. Nos casos de lançamento de ofício, serão aplicadas as seguintes multas:

I - de $75 \%$ (setenta e cinco por cento) sobre a totalidade ou diferença de imposto ou contribuição nos casos de falta de pagamento ou recolhimento, de falta de declaração e nos de declaração inexata."
} 
Por tal raciocínio asseveramos que as disposições constantes da Lei $\mathrm{n}^{\circ} 8.212$, de 1991, estatuídas pela Lei n 9.528, e discutidas neste capítulo, se mostravam adequadas, garantindo proteção ao CNIS, sempre que a Receita Federal, o poder competente segundo a lei, agisse, fiscalizando se o contribuinte tinha cumprido seu dever de informar. Isso porque a medida sancionatória que a lei previa, continha, além da pesada multa administrativa punitiva do inadimplemento, ou da inexatidão, a previsão de perdão no caso do arrependimento eficaz, ou seja, quando o inadimplente cumprisse sua obrigação de fazer, de presta as informações, mesmo que após a atuação estatal.

O Estado, reconhecendo a importância da informação social para o trabalhador, permitia uma segunda chance à empresa, facultava ao devedor outro prazo para o cumprimento da obrigação, e nesse caso, o dispensava-o da multa sancionatória.

Não há como se obrigar a empresa, ou o equiparado, ao cumprimento de uma obrigação de fazer. Há sim como sancioná-lo, como puni-lo. Mesmo com a distância que cabe entre uma obrigação legal e uma convencional, podemos nos socorrer de alguns ensinamentos do direito civil que se aplicam para o nosso caso.

Nesse sentido, da impossibilidade da exigência do cumprimento da obrigação de fazer, Caio Mario da Silva Pereira, leciona:

\begin{abstract}
Diversamente do que se dá com a 'obligatio dandi', que em princípio comporta execução específica, o credor não pode impor ao 'reus debendi' a prestação de fato, sem prejuízo do respeito à sua personalidade. [...] Não sendo lícito ao credor obter um comando judicial imperativo, pois que ninguém pode ser compelido à prática de um ato especificamente [...], não se comprazendo a ordem jurídica com o descumprimento voluntário da obrigação, o artigo estabelece a transformação da prestação no ressarcimento do prejuízo [...]. ${ }^{296}$
\end{abstract}

Inferimos, com a ressalva da distinção entre a obrigação convencional e a legal, que não há meios pelos quais o Estado obrigue a empresa ao preenchimento da GFIP. Óbvio que o descumprimento do dever legal de informar ensejará a aplicação da pena prevista na lei. Não há, portanto, complacência com o descumprimento voluntário: a empresa relapsa, morosa, arca com um custo por essa sua omissão.

As grandes questões que se põem são: qual a serventia para a sociedade desse tipo de sanção, desse tipo de constrangimento patrimonial? Ainda que se reverta todo o valor arrecadado com as multas pela não entrega da GFIP e mesmo essas sendo majoradas ao

\footnotetext{
${ }^{296}$ PEREIRA, Caio Mário da Silva. Instituições de Direito Civil. vol. II. 24. ed. Rio de Janeiro: Ed. Forense,
} 2011. p.59. 
maior valor cabível, estaria o Estado protegendo o sistema social que ele mesmo concebeu?

De certo que não. A efetiva proteção ao bem tutelado pela lei, ou seja, a tutela real ocorreria se, na ausência do cumprimento da obrigação pela empresa ou equiparado, o sistema fosse reorganizado de modo que a informação chegasse ao CNIS, mesmo que por outra via ou tardiamente.

Havia algo parecido, contudo o legislador houve por bem mudar o sistema. Agora, nos cabe o esforço de delimitar outros meios de proteção efetiva das informações. É o que faremos no capítulo 8.

\subsection{Informações sociais nos casos de sentença condenatória em reclamatória trabalhista}

A Emenda Constitucional $n^{\circ} 20$, de 1998 , por meio da inserção do $\S^{\circ}$ no artigo 114, da Constituição Federal, atribuiu à Justiça do Trabalho a competência para execução de ofício das contribuições sociais previstas no artigo 195, inciso I, alínea 'a', e inciso II, além de seus acréscimos legais, decorrentes das sentenças que proferir. Tal competência, por força da Emenda Constitucional $\mathrm{n}^{\circ} 45$, de 2004, hoje consta do inciso VIII do mesmo artigo 114, porém com a mesma redação dada pela $\mathrm{EC} \mathrm{n}^{\circ} 20$.

Muito se discutiu, no mundo jurídico, sobre essa atribuição ao ramo especializado da Justiça Federal. ${ }^{297}$ Alguns entendiam que se tratava de mero expediente para aumento da arrecadação, outros que a viam como uma via de "prática e de justiça social, plenamente adaptável às exigências constitucionais e legais do ordenamento."298

Alguns juízes do trabalho, mesmo após o advento da Lei no 10.035, de 2000, que regulamentou a disposição da Emenda Constitucional $\mathrm{n}^{\circ} 20$, ainda entendem que a execução de ofício só pode ocorrer após a formação de um título executivo por meio de regular processo administrativo, pois leem a locução "de ofício", contida no inciso VIII do artigo 114 da Constituição, como sendo o dever imposto ao juiz de comunicar à Procuradoria da Fazenda Nacional a ocorrência de possível violação à legislação

\footnotetext{
${ }^{297}$ Para maiores considerações sobre o assunto, conferir LOMBARDI, André Luis Mársico. A importância da execução de ofícios das contribuições previdenciárias no processo do trabalho. Dissertação de mestrado, Faculdade de Direito da Universidade de São Paulo, São Paulo, 2012.

${ }^{298}$ LOMBARDI, André Luis Mársico. ob. cit. p. 24.
} 
previdenciária. ${ }^{299}$ Homero Batista Mateus da Silva, ${ }^{300}$ embora não compartilhando com a visão do Poder Constituinte Derivado quanto à forma de arrecadação das contribuições previdenciárias, entende que cabe à Justiça do Trabalho a execução de ofício dessas contribuições, mas somente da chamada quota patronal (artigo 195, I, a da CF) e da parte de responsabilidade do trabalhador (artigo 195, II), que deve ser retida pelo empregador, não cabendo ao juiz do trabalho executar as multas punitivas e as contribuições devidas aos terceiros, assim entendidas as contribuições devidas ao Sistema ' $\mathrm{S}$ '. 301

Não cabe no presente estudo adentrar em tema tão apaixonante e, nesse sentido, polêmico. Nosso trabalho exige, em face do enorme interesse social, que verifiquemos se as informações sociais decorrentes das decisões emanadas da Justiça do Trabalho - sem dúvida, o ramo mais social do Judiciário Federal - povoam o banco de dados do trabalhador, e a partir disso, se integram o salário-de-benefício, uma vez que, como dito, acarreta a execução de ofício das contribuições sociais previdenciárias devidas. Para tanto, passando ao largo dos pontos controversos, examinemos o procedimento da Justiça Laboral para a execução das contribuições previdenciárias.

A regulamentação do inciso VIII do artigo 114 da Carta de 1988, com a redação dada pela $\mathrm{EC}^{\circ}$ 45, de 2004, deu-se pelo advento das Leis $\mathrm{n}^{\circ} 10.035$, de 2000, 11.457, de 2007, e 11.941, de 2009, as quais deram nova redação a artigos da CLT e da própria Lei n $^{\circ}$ 8.212, de 1991.

Observemos as disposições da Lei de Custeio:

Art. 43. Nas ações trabalhistas de que resultar o pagamento de direitos sujeitos à incidência de contribuição previdenciária, o juiz, sob pena de responsabilidade, determinará o imediato recolhimento das importâncias devidas à Seguridade Social.

$\S 1^{\underline{o}}$ Nas sentenças judiciais ou nos acordos homologados em que não figurarem, discriminadamente, as parcelas legais relativas às contribuições sociais, estas incidirão sobre o valor total apurado em liquidação de sentença ou sobre o valor do acordo homologado.

$\S 2^{\underline{o}}$ Considera-se ocorrido o fato gerador das contribuições sociais na data da prestação do serviço.

$\S 3^{0}$ As contribuições sociais serão apuradas mês a mês, com referência ao período da prestação de serviços, mediante a aplicação

\footnotetext{
${ }^{299}$ LAURINO, Salvador Franco de Lima. A execução das contribuições sociais na Justiça do Trabalho. in BOUCINHAS FILHO, Jorge Cavalcanti; PEREIRA, José Luciano de Castilho; FAVA, Marcos Neves. (org). O Direito Material e Processual do Trabalho dos Novos Tempos: Estudos em Homenagem ao Professor Estevão Mallet. São Paulo: LTr, 2009. p. 573.

${ }^{300}$ Cf. SILVA, Homero Batista Mateus da. Curso de Direito do Trabalho Aplicado. Vol. 8. Rio de Janeiro: Elsevier, 2009. p. 102

${ }^{301}$ Ver considerações sobre as contribuições sociais parafiscais, denominadas comumente por 'terceiros', no item 4.4.3, do capítulo 4 .
} 
de alíquotas, limites máximos do salário-de-contribuição e acréscimos legais moratórios vigentes relativamente a cada uma das competências abrangidas, devendo o recolhimento ser efetuado no mesmo prazo em que devam ser pagos os créditos encontrados em liquidação de sentença ou em acordo homologado, sendo que nesse último caso o recolhimento será feito em tantas parcelas quantas as previstas no acordo, nas mesmas datas em que sejam exigíveis e proporcionalmente a cada uma delas.

$\S 4^{\circ}$ No caso de reconhecimento judicial da prestação de serviços em condições que permitam a aposentadoria especial após 15 (quinze), 20 (vinte) ou 25 (vinte e cinco) anos de contribuição, serão devidos os acréscimos de contribuição de que trata o $\S 6^{\circ}$ do art. 57 da Lei ${ }^{\circ}$ 8.213, de 1991.

$\S 5^{\circ} \mathrm{Na}$ hipótese de acordo celebrado após ter sido proferida decisão de mérito, a contribuição será calculada com base no valor do acordo.

$\S 6^{\circ}$ Aplica-se o disposto neste artigo aos valores devidos ou pagos nas Comissões de Conciliação Prévia de que trata a Lei nº 9.958, de 2000. (grifo nosso)

Temos no caput do artigo 43 a determinação para que o juiz do trabalho, sob pena de responsabilidade, determine o imediato recolhimento das importâncias devidas à Seguridade Social, estando ressalvado, no parágrafo $1^{\circ}$, que não existindo discriminação da natureza da verba paga ao trabalhador, todo o valor apurado em sentença ou no acordo homologado será considerado como base de cálculo das contribuições. Logo, interessa às partes a discriminação das verbas remuneratórias, ${ }^{302}$ passíveis de incidência, como se sabe, e das verbais indenizatórias ou que não possuam natureza salarial. A determinação do momento de ocorrência do fato gerador, estatuída no parágrafo $2^{\circ}$, minimizou, embora devesse ter sepultado, a discussão sobre o momento da incidência da contribuição previdenciária devida nas reclamatórias trabalhista. ${ }^{303}$ Por expressa determinação da Lei de Custeio, lei tributária e, portanto, apta a determinação do momento da ocorrência do fato imponível, ${ }^{304}$ este se dá na data da prestação de serviços.

\footnotetext{
${ }^{302}$ Entendemos que a discriminação da verba deve restar explicitada nos autos e na sentença ou no acordo homologado, uma vez que a natureza jurídica a ela aplicável decorre do motivo pelo qual foi paga e não do nomem juris adotado pela partes. Tal disposição da lei, que resguarda o interesse dos cofres da Seguridade Social, visa combater eventual conluio das partes ou ao interesse do juiz, que pode vir a homologar acordos construídos em flagrante evasão fiscal.

${ }^{303}$ Novamente enfrentamos questão polêmica dentro do tema da execução de ofício das contribuições sociais. Para maior aprofundamento, conferir LOMBARDI, André Luis Mársico. A importância da execução de ofícios das contribuições previdenciárias no processo do trabalho. Dissertação de mestrado, Faculdade de Direito da Universidade de São Paulo, São Paulo, 2012. p.53.

${ }^{304}$ Segundo o Código Tributário Nacional, artigo 116, a lei poderá determinar o momento da ocorrência do fato gerador. Cf. CARVAlHO, Paulo de Barros. Curso de Direito Tributário. 14. ed. São Paulo: Ed. Saraiva, 2002. p. 268
} 
A exata determinação do marco temporal em que houve o fato economicamente apreciável, causador do dever de recolher contribuição social previdenciária, é crucial, tendo em vista a possibilidade da perda do direito de exigir o tributo. A perda do direito pode ser ocasionada pela inércia da Fazenda Pública em realizar o lançamento, o qual é o procedimento administrativo tendente a verificar a ocorrência do fato gerador.

A morosidade implica a extinção do débito do sujeito passivo, acarreta desenlace obrigacional. $^{305}$ Segundo o artigo 173 do Código Tributário Nacional, ocorre decadência do crédito tributário após cinco anos contados a partir do primeiro dia do exercício seguinte ao que o tributo poderia ter sido lançado. ${ }^{306}$

Interpretando as questões referentes à contagem do prazo decadencial, especificamente quanto à determinação do marco inicial, o Superior Tribunal de Justiça assentou entendimento de que as disposições do artigo 173, inciso I, as quais asseveram que o prazo de caducidade inicia-se a partir do primeiro dia do exercício seguinte ao da ocorrência do fato gerador, devem ser aplicadas nos casos em que não há pagamento de nenhum valor referente ao tributo que se questiona, mormente se este tributo for do tipo sujeito ao lançamento por homologação. Havendo pagamento de qualquer valor, mesmo que ínfimo, vinculado ao tributo que se verifica, e sendo esse sujeito ao lançamento por homologação, como acontece com as contribuições sociais, o prazo deve ser contado a partir do mês da ocorrência do fato gerador, segundo as disposições do artigo $150, \S^{\circ}$, do CTN. $^{307}$

Forçoso concluir que, no caso das contribuições sociais devidas nas sentenças proferidas ou nos acordos homologados pela Justiça do Trabalho, aplica-se o prazo decadencial de cinco anos, contados a partir da competência da prestação de serviços que ensejou o pagamento da verba remuneratória, nos casos em que houve algum pagamento

\footnotetext{
${ }^{305}$ Cf. CARVALHO, Paulo de Barros. ob.cit. p. 463

${ }^{306}$ Art. 173, inciso I.

${ }^{307}$ CTN: Art. 150. "O lançamento por homologação, que ocorre quanto aos tributos cuja legislação atribua ao sujeito passivo o dever de antecipar o pagamento sem prévio exame da autoridade administrativa, opera-se pelo ato em que a referida autoridade, tomando conhecimento da atividade assim exercida pelo obrigado, expressamente a homologa.

....

$\S 4^{\circ}$ Se a lei não fixar prazo a homologação, será ele de cinco anos, a contar da ocorrência do fato gerador; expirado esse prazo sem que a Fazenda Pública se tenha pronunciado, considera-se homologado o lançamento e definitivamente extinto o crédito, salvo se comprovada a ocorrência de dolo, fraude ou simulação."
} 
de contribuições previdenciárias daquela competência no curso do contrato de trabalho, o que, como imaginamos, deva ocorrer na maioria dos casos. ${ }^{308}$

Em síntese, se a reclamatória trabalhista apresentar verbas condenatórias de natureza remuneratória que se diluem ao longo do contrato de trabalho, ocorrerá decadência das contribuições previdenciárias quando, na data do trânsito em definitivo da sentença ou da homologação do acordo, existirem competências incluídas no período anterior a cinco anos a contar desta data. Pela relevância, ressaltamos que, se a ocorrência do fato gerador ocorreu na data da prestação dos serviços, incidem juros de mora e multa moratória desde essa data, consoante o expressamente disposto no parágrafo $3^{\circ}$ do artigo 43, da Lei ${ }^{\circ}$ 8.212, de 1991, acima reproduzido. ${ }^{309}$

Infere-se, diante da conclusão acima, que, se por um lado há uma grande perda de arrecadação das contribuições previdenciária por causa da decadência desses créditos quando do trânsito em julgado da reclamatória, de outro, existe a incidência de juros e multa moratórios incidentes sobre as contribuições apuradas mensalmente, e que é a soma destas, contribuições mais encargos moratórios, que deve ser liquidada até o dia dez do mês seguinte ao da liquidação da sentença ou apuração do acordo.

Perscrutando as disposições celetistas sobre a matéria, entendemos relevante mencionar que o artigo 876, ao tratar da forma da execução das sentenças transitadas em julgado e dos acordos não cumpridos, dos termos de ajuste de conduta firmados mediante o Ministério Público do Trabalho, e dos termos de conciliação firmados perante as Comissões de Conciliação Prévia, explicita, em seu parágrafo único, que:

serão executadas ex-officio as contribuições sociais devidas em decorrência de decisão proferida pelos Juízes e Tribunais do Trabalho, resultantes de condenação ou homologação de acordo, inclusive sobre os salários pagos durante o período contratual reconhecido.

\footnotetext{
${ }^{308}$ Entendemos que o Fisco, caso tivesse fiscalizado o contribuinte, poderia ter verificado a ocorrência do fato gerador de contribuição previdenciária, em suma, trabalho remunerado, e que foi levado posteriormente ao conhecimento da Justiça do Trabalho. Desse prisma, a sentença trabalhista não cria crédito tributário, somente o reconhece como decorrência de fato gerador ocorrido e não oferecido espontaneamente à tributação pelo empregador. Tal premissa nos leva ao posicionamento adotado quanto à ocorrência da decadência do crédito tributário tal como exposto no texto.

${ }^{309}$ Como mencionado, a contagem do prazo decadencial e prescricional da contribuição previdenciária na reclamatória trabalhista é tema controverso na doutrina e na jurisprudência. Em face dos propósitos do presente trabalho não adentraremos na discussão e firmamos nossa posição ao longo da exposição. Porém, em respeito às opiniões contrárias, remetemos o leitor à decisão do TST (AIRR 288240.76.2007.5.12.0001, $8^{\text {a }}$ Turma, Rel Min. Dora Maria da Costa, DEJT 06/05/2010). Essa tem caráter paradigmático e revela o pensamento daqueles que apresentam entendimento diverso especialmente quanto à incidência de juros e multa moratórios. Disponível em: 〈http://www.tst.jus.br〉. Acesso em: 11 nov. 2012.
} 
A dicção da lei trabalhista aponta em sentido repudiado pela doutrina ${ }^{310}$ e principalmente pela jurisprudência ${ }^{311}$ que as contribuições devidas sobre toda remuneração existente no contrato de trabalho devam ser executadas pela Justiça do Trabalho de impulso. Ora, a Carta determina a cobrança das contribuições decorrentes das sentenças e acordos levados ao conhecimento do Juiz do Trabalho, o que, de maneira alguma, se mistura com as contribuições devidas pelo curso do contrato laboral.

Continuando na análise da lei, encontramos no artigo 878-A disposição que faculta ao devedor o pagamento imediato do quantum que entender devido, sem prejuízo da cobrança de eventuais diferenças apuradas no cálculo para a execução de ofício. Vejamos agora a transcrição dos parágrafos que interessam às contribuições sociais no tocante à liquidação da sentença constantes do artigo 979 da CLT:

Art. 879 - Sendo ilíquida a sentença exequenda, ordenar-se-á, previamente, a sua liquidação, que poderá ser feita por cálculo, por arbitramento ou por artigos.

$\S 1^{1^{\circ}}$-A. A liquidação abrangerá, também, o cálculo das contribuições previdenciárias devidas.

$\S 1^{\underline{0}-B}$. As partes deverão ser previamente intimadas para a apresentação do cálculo de liquidação, inclusive da contribuição previdenciária incidente.

$\S 3^{0}$ Elaborada a conta pela parte ou pelos órgãos auxiliares da Justiça do Trabalho, o juiz procederá à intimação da União para manifestação, no prazo de 10 (dez) dias, sob pena de preclusão.

$\S 4^{\circ}$ A atualização do crédito devido à Previdência Social observará os critérios estabelecidos na legislação previdenciária. (grifos nossos)

Sendo certo que a liquidação da sentença deverá conter o cálculo das contribuições previdenciárias devidas, observemos a determinação da intimação da União, por meio da Procuradoria Geral Federal, ${ }^{312}$ para manifestação sobre os valores apresentados.

\footnotetext{
${ }^{310}$ Cf. VIANNA, João Ernesto Aragonés. Curso de Direito Previdenciário. 4. ed. São Paulo: Atlas, 2011. p. 355.

311 TST, Súmula 368, I: “A Justiça do Trabalho é competente para determinar o recolhimento das contribuições fiscais. A competência da Justiça do Trabalho, quanto à execução das contribuições previdenciárias, limita-se às sentenças condenatórias em pecúnia que proferir e aos valores, objeto de acordo homologado, que integrem o salário de contribuição.” STF, RE 569.056/PA, em repercussão geral, rel. Min Menezes Direito, Tribunal Pleno, em 11/09/2008. Recurso extraordinário. Repercussão geral reconhecida. Competência da Justiça do Trabalho. Alcance do art. 114, VIII, da Constituição Federal. 1. A competência da Justiça do Trabalho prevista no art. 114, VIII, da Constituição Federal alcança apenas a execução das contribuições previdenciárias relativas ao objeto da condenação constante das sentenças que proferir. 2 . Recurso extraordinário conhecido e desprovido. Disponível em: <www.stf.jus.br〉. Acesso em: 11 nov. 2012.

312 Portaria Conjunta PGF/PGFN no 433, de 2007, delegou à PGF a representação judicial da União nos processos perante a Justiça do Trabalho relacionados a cobrança de contribuições previdenciárias.
} 
Importante realçar a determinação específica da lei processual trabalhista sobre o respeito à lei previdenciária quanto à atualização do crédito tributário previdenciário, o que, acrescido ao exposto, nos posiciona de maneira contrária às determinações do TST no tocante à incidência da mora nas contribuições previdenciárias executadas de ofício.

Vistos, mesmo que em apertada síntese, os contornos da execução de ofício das contribuições previdenciárias nas reclamatórias trabalhistas, passemos a investigar se o efetivo ingresso crescente de recursos ${ }^{313}$ nos cofres da seguridade social, por essa via de cobrança, apresenta a necessária vinculação dos recursos aos seus efetivos destinatários, ou seja, aos trabalhadores que tiveram sentenças trabalhistas que reconheceram seus direitos decorrentes do trabalho remunerado que exerceram.

Percorremos, após a observação da análise das disposições constitucionais, por meio de nossos comentários acima, toda legislação trabalhista e previdenciária afeta à execução de ofício das contribuições previdenciárias. Como se pode verificar, não houve uma menção sequer à obrigação de prestar informações à Previdência Social e ao FGTS decorrente da reclamatória trabalhista.

Triste constatação. O legislador se esquece, ou pior, desconhece, como se garante um benefício previdenciário. Também a doutrina, ${ }^{314}$ praticamente unânime em reconhecer a importância do recolhimento da contribuição previdenciária decorrente da reclamatória trabalhista procedente para os benefícios previdenciários do trabalhador, não se recorda de que o efetivo ingresso do valor incidente das verbas remuneratórias recolhido pela empresa e pelo trabalhador e concedido por sentença ou acordos homologados só ocorrerá por meio das informações contidas na Guia de Informações ao FGTS e à Previdência Social.

313 A tabela abaixo reproduz a arrecadação das contribuições previdenciárias, em bilhões de reais, que cresceram $175 \%$ em dez anos, segundo Aragonés Vianna.

\begin{tabular}{|l|l|l|l|l|l|l|l|l|l|l|}
\hline Ano & 2001 & 2002 & 2003 & 2004 & 2005 & 2006 & 2007 & 2008 & 2009 & 2010 \\
\hline Total & 0,692 & 0,713 & 0.796 & 0,980 & 1,169 & 1,244 & 1,260 & 1,511 & 1,807 & 1,903 \\
\hline
\end{tabular}

VIANNA, João Ernesto Aragonés. Curso de Direito Previdenciário. 4. ed. São Paulo: Atlas, 2011. p. 359.

${ }^{314}$ Aragonés Vianna explicita, ao justificar a importância da execução de ofício pela Justiça do Trabalho, que "esses recursos são revertidos em prol de toda a sociedade", quando se sabe que devem ser revertidos em prol daquele que contribuiu para a segurança previdenciária por meio de um sistema geral, público e obrigatório. (VIANNA, João Ernesto Aragonés. Curso de Direito Previdenciário. 4. ed. São Paulo: Atlas, 2011. p.359.) Homero Batista recorda: "É inegável que os salários pagos por força de decisão judicial devem ser acompanhados dos tributos devidos, [...] como no que concerne à Previdência Social." (SILVA, Homero Batista Mateus da. Curso de Direito do Trabalho Aplicado. Rio de Janeiro: Elsevier, 2009. p. 97). A posição de André Lombardi é uma feliz síntese do entendimento doutrinário: "o processo judicial é o instrumento para a realização dos direitos, sendo que o papel da Justiça do Trabalho não é ser um agente arrecadador do Estado, mas de garantir os direitos fundamentais do trabalhador." (LOMBARDI, André Luis Mársico. A importância da execução de ofícios das contribuições previdenciárias no processo do trabalho. Dissertação de mestrado, Faculdade de Direito da Universidade de São Paulo, São Paulo, 2012. p. 144) 
Recordemos que o trabalhador que propõe uma ação em função de contrato de trabalho mantido com empregador e tem sentença que acolhe seu pleito ou celebra acordo no curso da ação, por óbvio, trabalhou para empresa ou para um equiparado, ${ }^{315}$ sendo dever desses a confecção e envio da GFIP. Portanto, estando o trabalhador vinculado a uma empresa, não terá ele outro meio de registro dos dados do contrato de trabalho ocorrido entre ele e a empresa mencionada exceto pela GFIP. Isso porque, como vimos, o CNIS é abastecido, no mais das vezes, pela GFIP ou pelo recolhimento da contribuição pelo trabalhador em GPS identificada pelo seu NIT ou PIS (o que não se aplica para o caso da execução de ofício) ou ainda pelo sistema de benefícios do INSS, que indubitavelmente não se verifica no caso em apreciação.

Logo, temos convicção de que só haverá efetivo aproveitamento da contribuição devida pelo trabalhador que sofre a violação do seu direito trabalhista e tem que suportar um longo processo judicial para tê-lo reparado se os dados referentes a esse processo ingressarem no Cadastro Nacional de Informações Sociais, por intermédio da GFIP, uma vez que é com base nesses dados que se concede e calcula o valor dos benefícios previdenciários.

Em conclusão, ou o reclamado preenche e envia a GFIP segundo as orientações constantes do item 8 do Capítulo IV do Manual da GFIP, aprovado pela Instrução Normativa RFB $\mathrm{n}^{\circ} 880$, de 2008, ou as informações sociais decorrentes da reclamatória trabalhista não serão registradas no CNIS, com óbvio prejuízo ao trabalhador, que não poderá aproveitar do resultado da ação judicial que reconhecer seus direitos trabalhistas e previdenciários subtraídos pelo empregado, nem mesmo no caso do recolhimento das contribuições sociais devidas ser efetuado. Única exceção a essa assertiva ocorrerá no caso de o próprio trabalhador levar ao INSS todas as informações necessárias para o registro, inclusive com cópia dos recolhimentos efetuados, em face da inversão do ônus da prova criado pela Lei Complementar $\mathrm{n}^{\circ} 128$, de 2008, mencionada no item 6.3 do presente trabalho.

Por certo, tal situação seria por demais custosa ao trabalhador, ${ }^{316}$ e pior, como sempre alertamos, quantos trabalhadores teriam consciência do tema que aqui analisamos?

315 Salvo nos casos de empregador doméstico.
${ }^{316}$ Além da dificuldade que o trabalhador teria para fazer a prova junto ao INSS, ainda cabe, neste ponto, a
polêmica questão sobre o reconhecimento dos direitos previdenciários, especialmente quanto ao
reconhecimento de vínculo, decorrente das sentenças trabalhistas, quando estas são baseadas em provas
exclusivamente testemunhais, em face das disposições constantes do $\S 3^{\circ}$ do artigo 55 da Lei $n^{\circ} 8.213$, de
1991. Para maior aprofundamento, indica-se a leitura de LOMBARDI, André Luis Mársico. A importância 
Eles efetivamente teriam condições de entender o que ocorreu, as consequências, saber como corrigir, e mais, fazer a prova necessária para a correção das informações constantes de seu cadastro social? Receamos que não.

\title{
7.6 Informações sociais nos casos de aferição indireta
}

Segundo o artigo 148 do Código Tributário Nacional, aprovado pelo Decreto $\mathrm{n}^{\circ}$ 5.172, de 1966, sempre que sejam omissos ou não mereçam fé as declarações ou os esclarecimentos prestados ou os documentos expedidos pelo sujeito passivo ou pelo terceiro legalmente obrigado, a autoridade fiscal arbitrará o montante devido do tributo.

Cumprindo os ditames do CTN, recepcionada pela Carta de 1988 com status de lei complementar que tem por função estabelecer normas gerais em matéria de legislação tributária, ${ }^{317}$ a Lei $\mathrm{n}^{\circ}$ 8.212, de 1991, ao tratar dos casos em que os documentos expedidos pelo contribuinte ou as informações por ele prestadas não permitam a real verificação do critério quantitativo da regra matriz de incidência tributária, assim disciplinou:

\begin{abstract}
Art. 33. À Secretaria da Receita Federal do Brasil compete planejar, executar, acompanhar e avaliar as atividades relativas à tributação, à fiscalização, à arrecadação, à cobrança e ao recolhimento das contribuições sociais previstas no parágrafo único do art. 11 desta Lei, das contribuições incidentes a título de substituição e das devidas a outras entidades e fundos.

$\S 1^{\circ}$ É prerrogativa da Secretaria da Receita Federal do Brasil, por intermédio dos Auditores-Fiscais da Receita Federal do Brasil, o exame da contabilidade das empresas, ficando obrigados a prestar todos os esclarecimentos e informações solicitados o segurado e os terceiros responsáveis pelo recolhimento das contribuições previdenciárias e das contribuições devidas a outras entidades e fundos.

...

$\S 3^{\circ}$ Ocorrendo recusa ou sonegação de qualquer documento ou informação, ou sua apresentação deficiente, a Secretaria da Receita Federal do Brasil pode, sem prejuízo da penalidade cabível, lançar de ofício a importância devida.

$\S 4^{\circ}$ Na falta de prova regular e formalizada pelo sujeito passivo, o montante dos salários pagos pela execução de obra de construção civil pode ser obtido mediante cálculo da mão de obra empregada, proporcional à área construída, de acordo com critérios estabelecidos pela Secretaria da Receita Federal do Brasil, cabendo ao proprietário, dono da obra, condômino da unidade imobiliária ou empresa corresponsável o ônus da prova em contrário.
\end{abstract}

da execução de ofícios das contribuições previdenciárias no processo do trabalho. Dissertação de mestrado, Faculdade de Direito da Universidade de São Paulo, São Paulo, 2012. p.126-138.

${ }^{317}$ Conforme o disposto no artigo 146, inciso III, alíneas 'a' e 'b', da Constituição Federal. 
$\S 6^{\circ} \mathrm{Se}$, no exame da escrituração contábil e de qualquer outro documento da empresa, a fiscalização constatar que a contabilidade não registra o movimento real de remuneração dos segurados a seu serviço, do faturamento e do lucro, serão apuradas, por aferição indireta, as contribuições efetivamente devidas, cabendo à empresa o ônus da prova em contrário. (grifo nosso)

A leitura atenta dos parágrafos transcritos do artigo 33 da Lei de Custeio nos permite deduzir que, existindo recusa ou sonegação de informação ou apresentação de documento, ou ainda falta de formalização e de regularidade dos lançamentos contábeis ou mesmo omissão ou inexatidão em seu conteúdo, o Fisco poderá lançar por aferição indireta, ou seja, por arbitramento, as contribuições devidas.

Tal procedimento excepcional, cabível somente quando a situação prevista na Lei de Custeio como ensejadora da aferição indireta for comprovada pelo Auditor Fiscal da Receita Federal do Brasil, visa resguardar o interesse público, representado pela necessidade do Estado de suprir os cofres da Seguridade Social com recursos previstos na Carta da República nos casos em que o sujeito passivo não cumprir as obrigações tributárias acessórias necessárias para que a Receita Federal possa verificar a real ocorrência e o dimensionamento do fato gerador tributário. ${ }^{318}$

Caminha pela mesma via o entendimento dos tribunais. Analisando a questão, o STJ decidiu que:

O artigo 148 do CTN deve ser invocado para a determinação da base de cálculo do tributo quando certa a ocorrência do fato imponível, o valor ou o preço de bens, direitos, serviços ou atos jurídicos registrados pelo contribuinte não mereçam fé, ficando a Fazenda Pública, neste caso, autorizada a proceder ao arbitramento mediante processo administrativofiscal regular, assegurados o contraditório e a ampla defesa. (...) Caso se entenda pelo inidoneidade dos documentos, a autoridade fiscal irá arbitrar, com base em parâmetros fixados na legislação tributária, o valor a ser considerado para efeitos de tributação. ${ }^{319}$

No âmbito do Tribunal Regional Federal da $4^{\mathrm{a}}$ Região, foi dito:

A aferição indireta ou arbitramento da base imponível do tributo é instrumento de tributação indiciária, ou seja, que torna possível ao Fisco a

\footnotetext{
${ }^{318}$ HARET, Florence. Teoria e Prática das presunções em direito tributário. São Paulo: Noeses, 2010. p 207-218.

319 STJ, $2^{\text {a }}$ T, RMS 26.964/GO, Rel. Min. Castro Meira, ago/2008, apud PAULSEN, Leandro. Direito Tributário: Constituição e Código Tributário à Luz da Doutina e da Jurisprudência. Porto Alegre: Livraria do Advogado, 2009. p. 1027.
} 
determinação e quantificação do fato tributário com base em indícios de sua ocorrência e dimensão, através da avaliação qualitativa e quantitativa de elementos extra-contábeis. Não tem a aferição indireta ou arbitramento natureza de sanção ou penalidade, apesar de ensejar, muitas vezes, situação tributária mais gravosa para o contribuinte. Em realidade, esse maior gravame eventual é mero aspecto acidental de sua conformação, que, por visar salvaguardar o crédito tributário, impõem critérios de quantificação bastante estritos do fato tributário com base em opção de seu máximo dimensionamento. ${ }^{320}$

Sendo um procedimento excepcional, a aferição indireta é cabível somente quando há a impossibilidade de verificação e quantificação do fato imponível, por falha dos documentos de responsabilidade do contribuinte. Mesmo nesses casos a quantificação por meios indiretos deve ser obtida da forma menos gravosa para o sujeito passivo. ${ }^{321}$ Como sempre dizemos, com finalidades didáticas, a aferição indireta é um remédio amargo que se toma com parcimônia.

Sendo certo que meros defeitos formais não ensejam a aferição e que o procedimento visa proteger a possibilidade da Administração Tributária constituir o crédito, e não sancionar per si o contribuinte, vejamos, focando nos nossos propósitos, a relação entre a aferição indireta e as informações sociais do trabalhador.

Assentamos que as contribuições sociais previdenciárias, como concluído no item 7.2, são um tributo que apresenta aspectos de taxa para o segurado obrigatório da Previdenciária Social, em face da contrapartida estatal inerente ao pagamento da contribuição. Tal aspecto se maximiza ao se recordar que a filiação se torna obrigatória com o mero trabalho remunerado, o que enseja, a partir de então, o direito aos benefícios previdenciários calculados sobre o valor da contribuição do trabalhador.

É certo que as contribuições previdenciárias, destinadas constitucionalmente para o custeio da Previdência Social, são constituídas de uma quota patronal, isto é, um quinhão incidente sobre a remuneração paga ou devida à pessoa física que trabalha e de uma quota suportada pelo próprio trabalhador, restando inequívoca a vinculação desses valores ao pagamento dos benefícios dos próprios trabalhadores. ${ }^{322}$

${ }^{320}$ Execução Fiscal no 2001.72.01.001723-8, $1^{\text {a }}$ Vara Federal de Joinville, apud PAULSEN, Leandro Direito Tributário: Constituição e Código Tributário à Luz da Doutina e da Jurisprudência. Porto Alegre: Livraria do Advogado, 2009. p. 1027.

${ }^{321}$ Estabelecido pelo parágrafo $6^{\circ}$ do artigo $6^{\circ}$ da Lei $n^{\circ}$ 8.021/90. Para o entendimento da doutrina, conferir FERRAGUT, Maria Rita. Presunções no Direito Tributário. São Paulo: Dialética, 2001.

${ }^{322}$ Aragonés Vianna entende que as contribuições vertidas pelos segurados "não são 'a fundo perdido', sem qualquer relação com os mesmos. Não! O valor dos salários de contribuição sobre os quais incidiram as contribuições, bem como o tempo de contribuição tem relação direta com a concessão dos benefícios 
Ao constituir um crédito por arbitramento, o Fisco não pode verificar in totum a base de cálculo do fato gerador; vislumbra a ocorrência deste, porém sob condições especiais, relacionadas à não conformidade da conduta do sujeito passivo. Essa impossibilidade de apuração da base imponível tributária na grande maioria das vezes, ${ }^{323}$ no nosso caso, se relaciona com a impossibilidade de apuração, pelo Fisco, do total da remuneração paga aos trabalhadores.

Tal impossibilidade, como visto, decorre da não apresentação dos documentos solicitados; da omissão de remuneração paga, devida ou creditada, constatada na folha de pagamento ou na contabilidade; da inconsistência dos dados apresentados nos documentos fornecidos diante do confronto desses com as informações obtidas pela fiscalização de outras fontes como, por exemplo, dados de reclamatórias trabalhistas, de informações prestadas ao Ministério do Trabalho ou outros documentos de posse do sujeito passivo. ${ }^{324}$

Resta claro que, ao constituir um crédito tributário previdenciário por aferição indireta, o Auditor Fiscal da Receita Federal do Brasil (AFRFB) verifica a ocorrência do fato gerador da contribuição previdenciária, ou seja, verifica a existência de trabalho remunerado prestado por pessoa física. Porém, não pode constatar a base de cálculo do tributo devido ou não pode encontrar o total da remuneração paga, ou, em outro giro, não consegue verificar se a totalidade das pessoas que trabalharam consta nos documentos apresentados, portanto, não lhe é possível observar a inconsistência entre os valores declarados como totais pagos e os valores efetivamente pagos.

Nestes casos, o AFRFB procederá ao lançamento tributário, por meio de Auto de Infração por aferição indireta, obtendo o total da remuneração paga aos segurados por via indireta e, sobre o valor aferido, incidirão as alíquotas correspondentes à contribuição da empresa e dos empregados, que deve ser, neste caso, suportada pelo empregador, dada a presunção da retenção obrigatória da quota do trabalhador pelo empregador.

De todo modo, há a constituição do total do crédito tributário devido, e após a constituição em definitivo decorrente do trânsito em julgado do processo tributário, por via de consequência, haverá o pagamento, espontâneo ou forçado, por meio da atuação do Estado Juiz.

previdenciários." (VIANNA, João Ernesto Aragonés. Curso de Direito Previdenciário. 4. ed. São Paulo: Atlas, 2011. p.358.)

${ }^{323}$ A Lei de Custeio prevê a incidência de contribuição previdenciária sobre outros fatos economicamente apreciáveis, distintos da folha de pagamento, como por exemplo, a nota fiscal ou fatura emitida por cooperativa de trabalho.

${ }^{324}$ A Instrução Normativa RFB no 971, de 2009, trata do tema a partir do artigo 447. 
Mais dia, menos dia, haverá o ingresso dos recursos nos cofres do INSS. Contudo, o que acontece com as informações sociais relativas ao crédito constituído pela atuação do Fisco? Nos casos de aferição indireta não cabe o envio da GFIP?

A resposta a essa questão deve ser cindida em duas partes, considerando duas situações. A primeira seria quando a aferição decorre da impossibilidade da verificação do total da remuneração, mas se constata que todos os trabalhadores foram identificados, caso típico da chamada 'meia folha', ou seja, há pagamento de valores aos trabalhadores 'por fora'. Outra seria quando não se pode afirmar que todos os trabalhadores constavam dos documentos apresentados pela empresa, ou seja, há trabalhadores não registrados, no sentido de não serem reconhecidos nos documentos do sujeito passivo.

Inexistindo a possibilidade de constatação do total da remuneração paga, mas se verificando que todos os trabalhadores que efetivamente prestaram serviços à empresa estão relacionados na folha de pagamento, e neste caso, existe o arbitramento da remuneração, resta claro que subsiste o dever da informação da diferença na proporção do recebido por cada trabalhador. Mera operação aritmética permitiria que os valores arrecadados pelo INSS em razão da presença fiscal fossem atribuídos a cada trabalhador, no quinhão que lhe caberia, garantindo os reflexos previdenciários decorrentes da atuação do Agente Público e do tributo pago pelo sujeito passivo, mesmo que após a ação fiscal. Há, portanto, total possibilidade do preenchimento da GFIP e por via de consequência povoamento das informações sociais no CNIS.

Em sentido diverso, ao menos em primeira análise, se apresenta a solução quando a aferição indireta decorrer da impossibilidade de verificação de que todos os trabalhadores que prestaram serviços ao sujeito passivo constavam dos documentos apresentados, isto é, não se pode identificar a totalidade dos que trabalharam no período da fiscalização empreendida, alguns entendem que ocorreria impedimento ou mesmo desobrigação, pelos próprios fundamentos que ensejaram o arbitramento, do preenchimento e envio da Guia de Informações ao FGTS e à Previdência Social.

Não nos filiamos a essa posição. Vislumbramos a possibilidade da identificação, pois a empresa, por óbvio, sabe quem para ela trabalhou, tem até mesmo o total a remuneração paga, todavia opta por não apresentar, ou por não reconhecer documentalmente. Entendemos que caberia ao Fisco tomar medidas tendentes a forçar, a constranger a empresa ao preenchimento da GFIP. Apresentaremos nossa sugestão no capítulo 8 . 
Por fim, ressaltamos que o entendimento acima apresentado coaduna-se com o procedimento de aferição indireta na construção civil, por meio do qual se cobram quando não há contabilidade formal e regular - as contribuições previdenciárias devidas pela construção de obra de construção civil com base na área, tipo e padrão da edificação ou no valor do contrato das demais obras de construção civil. 


\section{CAPÍTULO 8 - PROPOSTAS PARA UMA TUTELA EFETIVA}

\subsection{O que se quer proteger}

Ao longo do presente estudo, apresentamos a incoerência sistêmica que se verifica, após o advento da Lei n ${ }^{\circ} 11.941$, de 2009, quanto à atuação do Fisco Federal no tocante à exigência do cumprimento do dever da empresa, ou do a ela equiparado, de prestar informações sociais do trabalhador por meio do preenchimento e envio da Guia de Informações ao FGTS e à Previdência Social (GFIP).

Concebido como fonte de armazenamento de todas as informações sociais do trabalhador, o Cadastro Nacional de Informações Sociais (CNIS) é abastecido ${ }^{325}$ mensalmente com os dados do contrato de trabalho e da remuneração correspondente de todos os trabalhadores que prestam serviços formais em território nacional. ${ }^{326}$ Sendo a fonte oficial de dados sociais, a Lei Complementar $\mathrm{n}^{\circ} 128$, de 2008, ampliou a determinação para que o INSS utilizasse os dados do CNIS sobre os vínculos, as remunerações do segurado, comprovação de filiação ao RGPS, tempo de contribuição e relação de emprego, para fins de cálculo do salário de benefício, conforme as disposições constantes do artigo 29-A da Lei ${ }^{\circ}$ 8.213, de 1991.

Patente que os dados constantes do CNIS dão concretude aos benefícios previdenciários, pois eles alimentam o sistema que os calcula e os concede, após serem verificadas as condições de fato que os ensejam. Nesse diapasão, quer-se proteger as informações sociais do trabalhador. Em outros termos, precisa-se tutelar as informações do trabalhador no Cadastro Nacional de Informações Sociais, e para tanto, defende-se neste estudo que a eficácia da tutela materializa-se pela garantia de que as informações sobre o trabalho prestado pelo cidadão, bem como a remuneração percebida, sejam enviadas ao CNIS.

Importante apontar que o todo o sistema concebido é apropriado e vem, ao longo dos anos, sendo aprimorado e capaz de cumprir os objetivos que motivaram sua criação.

\footnotetext{
${ }^{325}$ Para maiores detalhes ver capítulo 6.

${ }^{326}$ Em 2009, havia 41,97 milhões de contribuintes no Regime Geral de Previdência Social RGPS, mais 7,17 milhões de segurados especiais, totalizando 49,14 milhões de trabalhadores com idade entre 16 e 59 anos contribuindo para o RGPS. Contribuíam para um regime próprio de previdência servidores públicos, mais 6,32 milhões de trabalhadores, o que totalizava, na data, 67\% dos trabalhadores brasileiros. Restavam, portanto, 33\% de trabalhadores informais. Cf. VIANNA, João Ernesto Aragonés. Curso de Direito Previdenciário. 4. ed. São Paulo: Atlas, 2011. p.48.
} 
Pode-se dizer que, havendo o adimplemento espontâneo das obrigações pelos sujeitos envolvidos, a Administração pode desvencilhar-se das suas atribuições com eficiência e controle.

Até pelo exposto, resta límpido que o próprio Cadastro Nacional deve ser protegido e que as informações nele dispostas devem ser tuteladas. Aprendemos, quando nos debruçamos sobre o CNIS, ${ }^{327}$ que essas informações provêm de várias fontes e são enviados por vários veículos coordenados. E, mais, as informações são checadas, em processo de confrontação, de modo a buscarem-se eventuais incoerências, em procedimento com nítido propósito acautelador, garantidor da qualidade da informação armazenada.

Não obstante o exposto, e recordando uma vez mais que o maior veículo de informações destinadas ao CNIS é a GFIP, o que se verifica hoje, principalmente após o advento da Lei $\mathrm{n}^{\mathrm{o}} 11.941 / 09$, é que o maior descompasso entre o trabalho prestado e a informação enviada ocorre quando, descumprido o dever de prestar a informação pelo obrigado, ou seja, nos casos de descumprimento da obrigação acessória de entrega da GFIP, há a atuação do Fisco no sentido do cumprimento da obrigação, porém com foco absoluto na arrecadação tributária e total desinteresse da informação social.

Exsurge o que se quer proteger: a informação da vida laboral do trabalhador no Cadastro Nacional de Informações Sociais. Para tanto, é preciso também tutelar os veículos que carregam essas informações. Veremos, linhas adiante, nossas sugestões de como efetivar essa proteção.

\subsection{Quando se deve proteger}

Afirmado que são as informações sociais nosso objeto imediato de tutela, posto que assim o objeto mediato de tutela se torna o acesso aos benefícios previdenciários pelo trabalhador brasileiro, filiado ao Regime Geral de Previdência, enfrentemos agora a questão do momento em que se deve buscar essa proteção.

A obrigação de prestar as informações referentes à folha de pagamento das empresas deve ser cumprida até o dia sete do mês seguinte ao da competência informada por meio do preenchimento e envio da GFIP, mesmo quando não há ocorrência de fato gerador previdenciário. Logo, por óbvio, a proteção das informações deve ser assegurada a

\footnotetext{
${ }^{327}$ Capítulo 6, item 6.5, do presente trabalho.
} 
partir do vencimento da obrigação, ou seja, deve-se impelir o cumprimento da obrigação no prazo legalmente estabelecido.

Tal incentivo ao cumprimento espontâneo e tempestivo do dever de informação reveste-se de importância ao se recordar que todo o sistema se aperfeiçoa com o procedimento corretamente adimplido. Nesse sentido, mesmo no caso do descumprimento do envio da GFIP até o dia 07 do mês seguinte, ou seja, dentro do prazo, devem-se adotar medidas que instiguem a empresa ao adimplemento mais rápido possível da obrigação.

Em suma, considerando que todo o sistema se ajusta quando do recebimento da informação do trabalhador pelo CNIS, a melhor proteção ao trabalhador ocorre quando os dados dele são enviados ao sistema cadastral o mais próximo possível do fato ocorrido.

\subsection{Quem deve proteger}

Esmiuçamos no capítulo 5 a natureza jurídica da GFIP e concluímos pela dupla natureza: obrigação tributária acessória e obrigação legal de caráter social. Agora devemos enfrentar a questão de máxima importância: a quem cabe o dever de proteger a GFIP, e por via de consequência, o CNIS.

Conhecendo-se o sistema pelo qual o CNIS é alimentado, em um primeiro olhar, pode parecer que a afirmação acima padece de reducionismo na análise do problema, uma vez que a GFIP não é o único veículo que colige informações ao Cadastro Nacional. O sistema de arrecadação e controle da GPS do contribuinte individual, o sistema de benefícios da Previdência Social, o sistema que concentra o CPF, o CNPJ, o CAGED, em suma, uma vasta gama de sistemas independentes e provenientes de vários órgãos transmitem dados para o CNIS. ${ }^{328}$ Porém, nenhum deles, isolados ou associados, possuem uma variedade tão grande de informações e de tantos segurados quanto a GFIP. E mais, os outros sistemas, em regra, são ligados à Administração Pública, direta ou indireta, o que nos permite pressupor uma maior aderência ao cumprimento das determinações impostas pelo ordenamento jurídico.

Por essas razões, nosso maior foco é a proteção da GFIP, em razão de nosso propósito de empreender um trabalho que proponha maior efetividade na tutela das informações sociais do trabalhador como garantia de acesso aos benefícios previdenciários.

\footnotetext{
${ }^{328}$ Ver capítulo 6, item 6.1.
} 
Tal proteção, entendemos, consegue-se quando há preenchimento correto e envio tempestivo do documento.

Esse é o objeto maior de nosso estudo: construir o modelo mais eficaz para o cumprimento da obrigação do preenchimento e envio da Guia de Informações ao FGTS e à Previdência Social e assim conseguir o povoamento dos dados dos trabalhadores no Cadastro Nacional de Informações Sociais. Firmes em nosso propósito, buscaremos definir o responsável por zelar pelo adimplemento, por parte do obrigado, do dever de prestar informações do trabalhador ao gerenciador do sistema de benefícios da Previdência Social.

À GFIP, prevista em lei federal, tributária, a Lei ${ }^{\circ}$ 8.212/91, remetem, também, a Lei do FGTS, lei $n^{\circ} 8.036$, de 1990, e a Lei $n^{\circ} 8.213$, de 1991, denominada de Lei de Benefícios. Tais constatações já nos indicam o caminho a trilhar, pois, decorrente de lei, o dever de preencher e transmitir a GFIP deve ser fiscalizado pelo Estado, por aqueles a quem compete verificar o cumprimento de todas as disposições das leis mencionadas. ${ }^{329}$ De plano, portanto, encontramos dois agentes públicos competentes: o Auditor Fiscal da Receita Federal do Brasil e o Auditor Fiscal do Trabalho.

A competência do Auditor Fiscal da Receita Federal do Brasil decorre da própria Lei de Custeio, que, em seu artigo 33, preceitua:

\begin{abstract}
Art. 33. À Secretaria da Receita Federal do Brasil compete planejar, executar, acompanhar e avaliar as atividades relativas à tributação, à fiscalização, à arrecadação, à cobrança e ao recolhimento das contribuições sociais previstas no parágrafo único do art. 11 desta Lei, das contribuições incidentes a título de substituição e das devidas a outras entidades e fundos.

$\S 1^{\circ}$ É prerrogativa da Secretaria da Receita Federal do Brasil, por intermédio dos Auditores-Fiscais da Receita Federal do Brasil, o exame da contabilidade das empresas, ficando obrigados a prestar todos os esclarecimentos e informações solicitados o segurado e os terceiros responsáveis pelo recolhimento das contribuições previdenciárias e das contribuições devidas a outras entidades e fundos [...]. (grifo nosso)
\end{abstract}

A clareza do texto legal torna desnecessárias maiores explanações. O Auditor Fiscal da Receita é o agente competente para executar as ações fiscais tendentes a verificar

\footnotetext{
${ }^{329}$ O poder de fiscalizar decorre do poder de polícia que segundo, Maria Sylva Zanella di Pietro, "é a atividade do Estado consistente em limitar o exercício dos direitos individuais em benefício do interesse público." Explicitando o conceito, assevera que a Administração Pública deve "no exercício da parcela que lhe é outorgada do mesmo poder, regulamentar as leis e controlar a sua aplicação, preventivamente (por meio de ordens, notificações, licenças ou autorizações), ou repressivamente (mediante imposição de medidas coercitivas)". Cf. DI PIETRO, Maria Sylvia Zanella. Direito Administrativo. 14. ed. São Paulo: Atlas, 2002. p.111. (grifos originais)
} 
o cumprimento das obrigações tributárias relativas às contribuições sociais previdenciárias. Ao se recordar que as obrigações tributárias, segundo o artigo 113 do $\mathrm{CTN}$, podem ser principais e acessórias e tendo a GFIP natureza jurídica deste tipo de obrigação, forçoso admitir a competência do AFRFB para a fiscalização da empresa quanto ao cumprimento do dever de informar a GFIP.

Não se discute, em âmbito algum, o acerto da competência legalmente imposta. De qualquer ângulo que se observe a questão, não resta dúvida alguma de que a melhor solução administrativa, a melhor técnica, a maior sinergia, a maior adequação para o contribuinte, é atribuir a fiscalização das obrigações tributárias acessórias à mesma autoridade que verifica o cumprimento das obrigações principais. Sendo a GFIP dever instrumental, a questão se resolve.

Totalmente diversa é análise quanto à sanção prevista na Lei de Custeio, que, quando aplicada pelo AFRFB, tem o condão de proteger somente uma finalidade do documento de informações ao FGTS e à Previdência, a finalidade tributária, como discutido alhures. ${ }^{330}$

No item 8.4 analisaremos medidas alternativas para uma solução condizente com a complexidade da GFIP. Por ora, registremos que a competência delegada para o Auditor Fiscal da Receita Federal adequa-se ao modelo da Administração Tributária existente no Brasil e é perfeitamente compatível com a dupla finalidade, tributária e social da GFIP. Porém, infelizmente, não se pode dizer o mesmo sobre o instrumento de sanção a disponibilizado ao Auditor pela lei para imputar ao contribuinte o cumprimento da obrigação legal. ${ }^{331}$

Também, por força de lei, compete ao Auditor Fiscal do Trabalho a fiscalização da GFIP. Constatamos que a guia de informações laboral cumpre conjuntamente os deveres tributários e sociais - assim entendido o dever de abastecer o CNIS com os dados dos trabalhadores -, o dever de permitir a verificação da regularidade do recolhimento do FGTS, além de individualizar o quantum do depósito realizado pelo empregador a ser creditado na conta de cada trabalhador. ${ }^{332}$

Segundo a Lei $n^{\circ} 8.036$, de 1990:

\footnotetext{
${ }^{330}$ Ver Capítulo 5, item 5.4.1.

331 Cf. ANDRADE FILHO, Edmar Oliveira. Infrações e Sanções Tributárias. São Paulo: Dialética, 2003.p.51.

${ }^{332}$ Ver Capítulo 5, item 5.3.1.
} 
Art. 23. Competirá ao Ministério do Trabalho e da Previdência Social a verificação, em nome da Caixa Econômica Federal, do cumprimento do disposto nesta lei, especialmente quanto à apuração dos débitos e das infrações praticadas pelos empregadores ou tomadores de serviço, notificando-os para efetuarem e comprovarem os depósitos correspondentes e cumprirem as demais determinações legais, podendo, para tanto, contar com o concurso de outros órgãos do Governo Federal, na forma que vier a ser regulamentada.

$\S 1^{\circ}$ Constituem infrações para efeito desta lei:

III - apresentar as informações ao Cadastro Nacional do Trabalhador, dos trabalhadores beneficiários, com erros ou omissões [...]. (grifo nosso)

No caput do artigo 23 da Lei $n^{\circ}$ 8.036, de 1990, Lei do FGTS, consta a delegação de competência ao Ministério do Trabalho para fiscalização do cumprimento da legislação de regência do FGTS, e quanto ao dever de recolhimento dos valores incidentes sobre o trabalho remunerado do empregado. Já o inciso III do parágrafo $1^{\circ}$ explicita que serão considerados infração à lei os erros e omissões que eventualmente constarem das informações prestadas ao Cadastro Nacional dos Trabalhadores, que, conforme estudamos no capítulo 6, era a denominação original do Cadastro Nacional de Informações Sociais.

Inegável que o direcionamento dado pelo legislador, quando do disciplinamento do Fundo de Garantia por Tempo de Serviço, já caminhava ao encontro do entendimento por nós esposado acerca da necessária tutela das informações constantes do atual CNIS.

Novamente, assim como dito com relação à competência do Auditor Fiscal da Receita Federal do Brasil, não há reparos à atribuição de competência para fiscalizar a GFIP, por se dizer concorrente, para o Auditor Fiscal do Trabalho, em face da íntima relação da atuação deste agente público com os fatos que originaram as informações constantes da Guia de Informações. É dizer que, mutatis mutandis, o que foi dito quanto à sinergia e ao acerto da fiscalização da GFIP por parte do AFRFB cabe ao AFT, e isso graças à dupla natureza jurídica da Guia de Informações ao FGTS e à Previdência Social.

Não obstante, imprescindível registrar - uma vez mais - a diferença fulcral que os atos normativos emprestam a um e a outro agente físcal quanto à sanção e à forma de autuação prevista na legislação aplicada por uma e por outra autoridade pública.

Ao Auditor Fiscal da Receita Federal do Brasil cabe a aplicação do artigo 32-A da Lei ${ }^{\circ} 8.212 / 91$, que comina multa de $2 \%$ sobre o valor devido por mês de atraso, limitado a $20 \%$ desse valor devido, no caso de mora na entrega, e multa de $\mathrm{R} \$ 20,00$ para cada grupo de dez informações incorretas ou omissas. Claríssimo o descaso com a importância das 
informações sociais constantes da GFIP, uma vez que, segundo o artigo 35-A, as informações referentes aos fatos geradores de contribuições sociais, se omitidas, causarão lançamento do correspondente crédito tributário acrescido de $75 \%, 150 \%$ ou $225 \%$ do valor devido. ${ }^{333}$

Totalmente diversa a autuação prevista nos normativos seguidos pelo Auditor Fiscal do Trabalho. Em primeiro lugar, deve-se ressaltar que cabe ao AFT fiscalizar o recolhimento do FGTS e que a fiscalização é realizada cotejando-se os valores devidos ao empregado, os valores declarados em GFIP e os valores efetivamente recolhidos. Para tanto, além de respeitar a dupla visita, antes da autuação - o que sem dúvida favorece o adimplemento da obrigação - o Auditor do Trabalho aplica sanção legalmente imposta, seguindo os procedimentos normatizados pela Instrução Normativa SIT n 99, de 2012, a qual determina expressamente que os valores lançados devem ser individualizados por trabalhador, mesmo nos casos aferição indireta. ${ }^{334}$ Tal procedimento certamente contribui para alimentar corretamente os dados dos trabalhadores relacionados junto ao CNIS, com os reflexos nos benefícios previdenciários decorrentes.

Aprofundaremos essa análise no próximo item do presente capítulo. Neste momento, guardemos a distinção: dois agentes públicos, dois tributos distintos, ${ }^{335}$ duas sanções com o mesmo objetivo. Porém, os resultados são díspares para o trabalhador, pois o esforço do AFT satisfaz ao empregado e o do AFRFB satisfaz somente ao Fisco.

Cabível, em alguma medida, verificar a atribuição de tutela das informações sociais a outros agentes, como por exemplo, ao Procurador do Trabalho e aos sindicatos de trabalhadores.

A Lei Complementar $n^{\circ} 75$, de 1993, ao estatuir as funções institucionais do Ministério Público Federal, em seu Título I, por meio do artigo $5^{\circ}$, inciso I, atribuiu ao MPF a função de defesa dos interesses sociais, considerando, entre outros fundamentos e princípios, os princípios fundamentais da República. Esses, como se sabe, encontram-se elencados no artigo $1^{\circ}$, e dentre eles, encontramos no inciso IV os valores sociais do trabalho.

Tratando da estrutura do Ministério Público da União, o artigo 24, inciso II, da mesma lei complementar, inclui o Ministério Público do Trabalho no parquet federal. As

\footnotetext{
${ }^{333}$ Para maiores considerações sobre a pena tributária ver item 5.4.1.

${ }^{334}$ Vide artigos 17, 30, 31 e 39 da Instrução Normativa SIT n 99, de 2012.

335 Já nos posicionamos, ao lado de Sergio Pinto Martins, quanto à natureza tributária do FGTS (ver nota de rodapé $\mathrm{n}^{\circ} 222$ )
} 
competências e incumbências do MPT são elencadas nos artigos 83 e 84, e dentre elas encontramos a de instaurar inquéritos civis e outros procedimentos administrativos para assegurar a observância dos direitos sociais dos trabalhadores, além de requisitar a instauração de procedimentos administrativos, ${ }^{336}$ nos casos que se entenderem cabíveis, às autoridades administrativas federais competentes dos órgãos de proteção ao trabalho. Pode-se entender como verdadeira tergiversação o entendimento de que o MPT não teria competência para proteger as informações transmitidas ao CNIS pelos obrigados, mormente ao se considerar a natureza de direito coletivo que se aplica ao conteúdo do Cadastro Nacional. Isso porque é evidente o caráter social das informações constantes do CNIS em face da sistemática de concessão dos benefícios previdenciários, verdadeiro direito social consoante as disposições do artigo $6^{\circ}$ da Constituição da República. Ademais, há que se considerar as atribuições de competência do Ministério Público do Trabalho, acima mencionadas. Embasados nesse mesmo raciocínio, caberia também ao MPT a proteção da GFIP, enquanto instrumento de abastecimento das informações junto ao CNIS, uma vez que entendemos ter a Guia de Informações conteúdo de interesse individual homogêneo. ${ }^{337}$

Mormente o exposto, não se pretende aprofundar a análise da competência atribuível ao parquet trabalhista. Consideramos que os Auditores Fiscais do Trabalho e da Receita Federal do Brasil realizam a tutela das informações sociais de maneira mais eficiente e efetiva. As competências específicas dessas duas categorias de agentes públicos e as características da GFIP comungam interesses.

Tal afirmação não prescinde da eventual representação administrativa que possa vir a ser confeccionada pelos Auditores Fiscais Federais para apuração de responsabilidades, se o Procurador do Trabalho entender cabível, como veremos no item 8.4.4, linhas adiante.

Por fim, analisemos a possível atribuição de competência dos sindicatos de empregados para fiscalização do dever de prestar informações. São óbices a essa atribuição a própria natureza institucional dos sindicatos que representam os empregados sindicalizados, o que exclui dessa defesa os outros trabalhadores que não possuem contrato de emprego e mais o caráter sigiloso dos dados constantes em GFIP referentes não só aos demais trabalhadores como também ao empregador. Diante dessas dificuldades, e ao

\footnotetext{
${ }^{336}$ Lei Complementar $n^{\circ} 75$, de 1993, artigo 84, inciso II e III.

${ }^{337}$ Por direitos transindividuais, ou individuais homogêneos, podemos entender os direitos subjetivos que se caracterizam pela união entre diversas pessoas em torno de um interesse comum. Cf. BELTRAN, Ari Possidonio. Direito do trabalho e direitos fundamentais. São Paulo: LTr, 2002. p. 273.
} 
recordarmos que a Resolução no 321, de 1991, da Caixa Econômica Federal já prevê a possibilidade de requisição dos dados constante em GFIP pelos sindicatos, não se observa nenhum motivo relevante para se propor tal atribuição de competência, pois há formas mais eficazes do sindicato atuar como agente de defesa dos interesses sociais dos trabalhadores.

Em resposta à questão que colocamos no princípio desta seção, entendemos que devem tutelar as informações sociais os Auditores Fiscais do Trabalho e os da Receita Federal do Brasil. Vejamos agora como poderiam ser implementadas essas tutelas.

\subsection{Proposta para efetiva proteção nos casos em geral}

Recapitulemos. Uma pessoa física que trabalha mediante remuneração torna-se, de plano, segundo o artigo 12 da Lei de Custeio, segurado obrigatório da Previdência Social e, portanto, contribuinte do Sistema de Seguridade Social. A partir desse momento, e cumprindo - quando for o caso - as carências previstas na Lei de Benefícios, passa a ter, dentre seus direitos subjetivos, os direitos previdenciários.

O gozo desses direitos, segundo o artigo 29-A da Lei $\mathrm{n}^{\circ} 8.213$, de 1991, deve ser concedido pelo INSS a partir dos dados do trabalhador constantes do Cadastro Nacional de Informações Sociais e da comprovação do motivo desencadeador do seguro previdenciário. Logo, a presença dos dados do trabalhador no CNIS é determinante para que o INSS cumpra sua função institucional, sendo por isso a Guia de Informações ao FGTS e à Previdência Social o veículo mais importante para o necessário registro das informações dos segurados.

Em síntese, podemos deduzir que, cumprido o dever de prestar informações sobre a prestação de serviços do trabalhador, os direitos previdenciários dele estarão implementados, prontos para quando for necessário suprir a renda decorrente do trabalho que, por força do evento futuro e incerto coberto pelo seguro social, não puder ser realizado. Descumprido o dever de prestar informações, tais diretos poderão não ser disponibilizados ao trabalhador. Tal descumprimento de preceito legal não pode ser tolerado pela sociedade.

Com o fito de impedir que essa conduta ocorra, torna-se necessário aplicar-se uma sanção, que, conforme Miguel Ángel de Arco Torres e Ana Isabel del Blanco: 
es medio jurídico para responder de manera preventiva o efectiva, con la aplicación de penas o sanciones administrativas a la posibilidad de desobedecer a la eficacia del derecho o a su cumplimento. ${ }^{338}$

Aqui repousa nosso desiderato maior: encontrar o meio jurídico para responder de maneira preventiva, efetiva e eficaz ao descumprimento de dever que impede o usufruto de um direito fundamental. A busca de nosso objetivo necessariamente passa pela análise da sanção como forma de coerção ao cumprimento de um dever, o que nos obriga a perquirir a teoria aplicável.

\subsubsection{Ilícito: conceito jurídico}

Adotando-se um conceito consolidado, pode-se dizer que o ilícito é o descumprimento de um dever, decorrente de lei ou de ato de vontade das partes.

Fixando-nos naqueles que advêm da lei, verificaremos que o ilícito decorre do descumprimento de uma norma de conduta, norma esta impositiva, que se diferencia de uma norma sancionatória. As impositivas têm hipótese de incidência composta por fatos que, ocorridos, ensejam um dever descrito no consequente da norma e, por certo, relacionado diretamente, ou seja, de possível ocorrência dentre os fatos previstos no antecedente, por isso dito hipótese de incidência.

Paulo de Barros Carvalho, tratando da questão, explicita que, se a proposiçãohipótese "é descritora de um fato de possível ocorrência no contexto social, a proposiçãotese funcionará como prescritora de condutas intersubjetivas." 339

Já as normas sancionatórias contêm em sua proposição, em seu antecedente, remissão à norma de conduta com a qual se relaciona, e possuem em seu consequente sanções pelo descumprimento da conduta imposta. Há no antecedente da norma sancionatória um comportamento violador de dever prescrito em norma de conduta, e no consequente, a prescrição de uma consequência tendente a reparar ou impedir os efeitos do comportamento indesejado pelo ordenamento. Assim, as normas sancionatórias possuem o

\footnotetext{
${ }^{338}$ ARCO TORRES, Miguel Ángel del; ARCO BLANCO, Ana Isabel del. Diccionário Básico Jurídico. 7. Ed. Granada: Comares Editorial, 2009. p.509. Em tradução livre: "Meio jurídico para responder de maneira preventiva ou efetiva com aplicação de pena ou sanções administrativas à possibilidade de desobedecer à eficácia do direito ou ao seu cumprimento."

${ }^{339}$ CARVALHO, Paulo de Barros. Direito tributário: fundamentos jurídicos da incidência. 6. ed. São Paulo: Saraiva, 2008. p. 30.
} 
"poder dissuasório e punitivo que o Direito direciona àqueles que descumprem os deveres legais.",340

\subsubsection{Sanção: conceituação e tipologia}

Paulo de Barros, sempre preocupado com a linguagem, com a ordem semântica, lista a acepção estrita do vocábulo sanção:

'norma jurídica em que o Estado-Juiz intervém como sujeito passivo da relação deôntica, sendo sujeito ativo a pessoa que postula a aplicação coativa da prestação descumprida. Mas há outra proporção significativa ligada a essa, qual seja, a de 'sanção' como sentença condenatória, ao cabo do processo judicial e ensejadora do procedimento coativo propriamente dito., 341

Vimos que, em sentido jurídico amplo, o vocábulo é empregado como consequência de atos contrários ao ordenamento, ações ou omissões que devem ser suportadas por aquele que agiu em desconformidade com determinada norma de conduta. Atentemos para a importância do sujeito, ou seja, alguém que agiu ou deixou de agir de acordo com uma prescrição, com uma determinação imposta por uma norma. Há um ato humano ensejador de nova conduta humana, esta reparadora, sancionatória.

Miguel Reale, citado por Edmar Andrade Filho, lembra que a sanção é inerente ao ato normatizável, uma vez que:

'desvinculada da sanção, a norma não poderia exercer
concomitantemente as duas funções complementares, a de
obrigatoriedade do que é normatizado e a de garantia dos limites da
obrigação declarada, consubstanciando sempre a problemática da
liberdade.' 342

Justamente sob o prisma da liberdade, há na questão da obrigatoriedade da norma de conduta, dupla função da norma sancionatória, da sanção em si: uma repressiva, reparadora, pela qual o agente é constrangido por descumprir norma de conduta, em razão da punibilidade, da pena imposta pela norma punitiva. Outra função, muitas vezes mais

\footnotetext{
340 COELHO, Sacha Calmon Navarro. Infração Tributária e Sanção. In MACHADO, Hugo de Brito (Coord.). Sanções Administrativas Tributárias. São Paulo: Dialética, 2004. p. 421.

${ }^{341}$ CARVALHO, Paulo de Barros. ob. cit. p. 44.

${ }^{342}$ REALE, Miguel. Nova fase do Direito Moderno. 1. ed. São Paulo: Saraiva, 1990. p.158.
} 
importante que a punitiva, é a preventiva, pela qual o sujeito é compelido a agir conforme o estatuído na norma de conduta por temer a punição prevista na norma sancionatória. A função preventiva, focada na liberdade que o sujeito tem de cumprir ou não a norma impositiva, no mais das vezes interessa ao Estado, mais em função do interesse tutelado do que qualquer função reparadora da sanção estipulada, pois o bem jurídico protegido já foi aviltado, e seu objeto é de difícil reparação.

Tal construção respalda a classificação das normas sancionatórias em duas espécies bem distintas, e por vezes contraditórias em termos, que são as sanções negativas e as sanções positivas.

A primeira, que podemos denominar sanção típica, traz em seu bojo a própria essência da sanção, a coerção intrínseca que o Direito possui para realizar o seu propósito de regular a vida em sociedade. É a mais grave, pois pode até atingir, e em alguma medida o faz todas as vezes que é empregada, direitos fundamentais do sancionado, sempre no sentido de restringi-los, e não de suprimi-los.

Por isso, a sanção, especialmente a de ordem penal, deve ser aplicada pela autoridade competente, muito embora, em alguns casos, o próprio ordenamento pressuponha a autotutela, como ocorre no âmbito da Administração Pública. Diversas são as sanções previstas no ordenamento, como as penas pecuniárias, as restritivas de direitos, as restritivas de liberdade, as nulidades e as declarações de ineficácia dos atos e negócios jurídicos etc., até chegarmos à sanção por execução forçada, aplicada nos casos de constrição patrimonial para cumprimento de obrigação.

Logo, as sanções negativas objetivam por vezes o exato cumprimento da obrigação, ou reparação do dano, ou ainda indenização, quando a reparação é difícil ou impossível. Em outras ocasiões, a sanção busca apenas a aplicação de um castigo, de uma pena. Tais conclusões nos permitem vislumbrar na norma sancionatória efeitos corretivos, repressivos, intimidativos e educativos. ${ }^{343}$

Tércio Sampaio Ferraz vê na sanção uma ameaça ao agente sujeito a uma norma de conduta, pois a "a lei que prevê uma sanção é ato perlocucionário de ameaçar no sentido de exercitar um ato, isto é, no sentido que ameaça, decidindo contra determinado comportamento." 344

343 Cf. ICHIHARA, Yoshiaki. Sanções Tributárias - Questões Sugeridas. In MACHADO, Hugo de Brito (Coord.). Sanções Administrativas Tributárias. São Paulo: Dialética, 2004. p.479.

${ }^{344}$ FERRAZ JUNIOR, Tércio Sampaio. Teoria da Norma Jurídica. 3. ed. Rio de Janeiro: Forense, 1987. p. 71. 
Claro que ao se sentir ameaçado, o agente tende ao cumprimento da norma, ao agir em conformidade com o ordenamento, que valida a função educativa da norma estipuladora de sanção, mesmo daquela que possui conteúdo negativo. Grande problema surge se a norma de conduta estipula uma obrigação de fazer, uma prestação pessoal, uma conduta, assim entendido um agir do sujeito, pois, no caso de descumprimento dessa norma, não se pode usar um sanção reparadora eficaz, uma execução forçada da obrigação legalmente imposta, já que não cabe no direito o constrangimento do agente ao facere. ${ }^{345}$

Em busca da solução desta questão, surgiu a sanção premial, a sanção positiva, que se relaciona com o conceito de mérito ou de prêmio. Essa consiste no reconhecimento pelo Estado que os comportamentos que interessam à sociedade devem ser fomentados, incentivados e demonstra a transformação dos ordenamentos jurídicos repressivos por excelência em ordenamentos com alguma ênfase na promoção do direito. Isso porque os primeiros se baseiam na penalização da conduta indesejada, já os segundos revelam postura típica do Estado do moderno Bem-Estar Social, nos quais há uma atuação promocional do Estado na realização dos ideais da sociedade.

Bobbio faz a distinção entre os ordenamentos promocionais, os quais possuem sanções premiais, e os protetores-repressivos, os quais se fundam na sanção negativa. ${ }^{346}$ Esses se interessam pelas condutas não desejadas socialmente, as quais devem ser impedidas; já aqueles, os promocionais, têm seu interesse focado nas condutas socialmente desejáveis e seu fim é provocá-las, inclusive entre aqueles sujeitos que, a princípio, não as praticam. Nesse aspecto, as sanções positivas são importantes instrumentos de realização principiológica.

Por sanções positivas, locução que carrega uma antinomia semântica flagrante ${ }^{347}$, entende-se a vantagem oferecida ao agente que, por agir em conformidade com uma norma de conduta, faz jus à condição favorável prevista no consequente da norma. Por isso, há no antecedente da norma sancionatória premial um ato lícito e, portanto, desejado pelo ordenamento. No consequente desta norma há uma vantagem, um prêmio previsto para aquele que incidiu na ação ou omissão desejada pelo ordenamento.

\footnotetext{
${ }^{345}$ Para maiores considerações ver item 7.4.

${ }^{346}$ BOBBIO, Norberto. Contribuición a la Teoria del Derecho. Madrid: Debate, 1990. p. 38.

347 Edmar Oliveira Andrade Filho entende que, ao se admitir que o direito positivo comporta sanções positivas, "há concomitante repúdio às concepções doutrinárias que consideram que a ordem jurídica contém unicamente normas que prescrevem sanções negativas". ANDRADE FILHO, Edmar Oliveira. Infrações e Sanções Tributárias. São Paulo: Dialética, 2003. p.53.
} 
Pode-se entender que as técnicas legislativas positivas são mais aperfeiçoadas para observar-se o cumprimento das normas jurídicas, pois influenciam o ânimo do agente, impulsionando-o no sentido buscado pela norma. ${ }^{348} \mathrm{Em}$ um mundo marcado pelo esforço externo em influenciar a decisão individual, a sanção positiva tem efeitos marcantes no cumprimento dos deveres legais ao se pensar que a sensação de impunidade em face da dificuldade do Estado de verificar a adesão a todas as condutas previstas é substituída pelo gozo de vantagem imediata surgida com o cumprimento de disposição normativa.

Assim, é importante apreendermos o objetivo descortinado por Edmar Oliveira Andrade nas sanções positivas: "O objetivo imediato de certas normas premiais é o de facilitar ou remover empecilhos ou dificuldades." 349

\subsubsection{Denúncia espontânea da infração}

Em um ordenamento jurídico promocional, usando a denominação de Bobbio, o Estado pode atribuir funções típicas ao cidadão, desencarregando-se delas, ao menos em parte, e contando com a atuação do particular, mesmo que num primeiro momento este atue contra seus próprios interesses. Para tanto, além de disposições coercitivas, típicas de uma lei, deve o Estado premiar o cidadão que adimple tempestivamente sua obrigação legal, o que não necessariamente implica que renegue seu direito de punir quem não age de acordo com a determinação legal.

A situação acima descrita é típica de direito tributário, mormente em dias atuais, em que a grande maioria dos tributos é lançada por homologação. Em outros termos, hoje, cabe ao contribuinte, sujeito passivo da obrigação tributária, apurar o quantum devido, informar ao Fisco sobre essa apuração e pagar o valor apurado na data determinada, de modo que o Estado relega ao cidadão uma função tipicamente sua, quantificar, calcular e arrecadar os seus tributos.

Nesse caso, o cidadão atua contra seu próprio interesse, pois por óbvio, o pagamento de tributo transfere renda do particular para o Estado. Quando há o adimplemento total da obrigação, em todo seu iter pelo obrigado, todo o sistema tributário se aperfeiçoa, restando ao Estado, com seus recursos escassos, somente gerenciar o sistema, verificando por indicadores a correção dos tributos recebidos.

348 REALE, Miguel. Lições Preliminares de Direito. 22. ed. São Paulo: Saraiva, 1995. p.27.
${ }^{349}$ ANDRADE FILHO, Edmar Oliveira. Infrações e Sanções Tributárias. São Paulo: Dialética, 2003.p.54. 
Porém, se os contribuintes deixarem de recolher o tributo devido na sua totalidade, será muito mais interessante ao contribuinte tentar ocultar sua falha, contando com a incapacidade do Estado de verificar a totalidade dos lançamentos tributários transferidos aos sujeitos passivos. Ao Fisco, por sua vez, não tendo capacidade de fiscalizar a todos, de pouco vale ter ao seu lado uma norma sancionatória que prevê a imposição de multa punitiva, multa moratória e juros compensatórios no caso de inadimplemento pelo contribuinte.

Neste cenário, algo que incentivasse o contribuinte ao adimplemento, mesmo que tardio, de sua obrigação, interessaria tanto ao Fisco, que teria o ingresso de seus recursos, quanto ao contribuinte, que minimizaria a chance de aplicação da sanção.

Leandro Paulsen assim analisa a questão:

'Uma norma de convergência, em tais situações, é bem vinda. O risco da punição não interessa ao contribuinte e o risco de jamais saber do ocorrido e, por consequência, de não receber o seu crédito não interessa ao Fisco.' 350

Norma com esse atributo foi prevista pelo legislador brasileiro, há quase 50 anos, em 1966 quando se elaborou o Código Tributário Nacional. O CTN, em seu artigo 138, trata da responsabilidade do sujeito passivo e a afasta, mediante o cumprimento da obrigação de pagar, desde que tal pagamento ocorra antes de qualquer procedimento de verificação proposto pelo Fisco. ${ }^{351}$

Analisando a disposição do CTN, Edmar Oliveira Andrade, comenta:

$\mathrm{O}$ preceito transcrito encerra um comando que visa a motivar um comportamento daquele que praticou a conduta descrita na norma penal tributária, o devedor faltoso, oferecendo-lhe a possibilidade de ter um castigo mais brando, incentivando-o a adimplir a obrigação [...]. Trata-se de norma de nítido caráter premial.

Forçoso concluir que já temos na legislação tributária previsão expressa de sanção positiva, demonstrando que há interesse do Estado em promover determinadas condutas,

\footnotetext{
${ }^{350}$ PAULSEN, Leandro. Denúncia Espontânea da Infração. In MACHADO, Hugo de Brito (Coord.). Sanções Administrativas Tributárias. São Paulo: Dialética, 2004. p.271.

351 CTN: Art. 138. A responsabilidade é excluída pela denúncia espontânea da infração, acompanhada, se for o caso, do pagamento do tributo devido e dos juros de mora, ou do depósito da importância arbitrada pela autoridade administrativa, quando o montante do tributo dependa de apuração.

Parágrafo único. Não se considera espontânea a denúncia apresentada após o início de qualquer procedimento administrativo ou medida de fiscalização, relacionados com a infração.
} 
mesmo quando ele, Estado, possui um forte poder coercitivo, como ocorre nos casos de responsabilidade tributária, ${ }^{352}$ uma vez que o maior interesse é o cumprimento da obrigação e não sua reparação ou indenização, ou mesmo aplicação pura e simples de sanção.

Esse será o caminho que pretendemos trilhar para obtermos uma tutela efetiva das informações sociais. Aliados à necessária coerção típica do direito tributário, vislumbramos a noção de sanção positiva como forma de incentivo ao adimplemento da obrigação de abastecer o Cadastro Nacional de Informações Sociais. Ainda, é o suporte teórico de que precisamos para uma legislação que respalde o veículo das informações sociais no âmbito dos interesses tributários envolvidos - tanto nos aspectos relativos ao Fundo de Garantia por Tempo de Serviço, quanto nas questões referentes às contribuições sociais previdenciárias - e no âmbito da proteção dos dados dos trabalhadores contidos na Guia de Informações ao FGTS e à Previdência Social e que serão armazenados no CNIS.

As palavras de Paulsen justificam ainda mais todo o dito:

"É importante estimular o contribuinte ao cumprimento espontâneo, ainda que tardio, das suas obrigações. Isso se faz mediante a desoneração das multas. Benefício maior implicaria desestímulo ao cumprimento tempestivo das obrigações; menos do que isso não teria efeitos". ${ }^{353}$

\subsubsection{Proposta para proteção efetiva}

Firmes na conclusão, até pelo exposto quando de nossa análise do Cadastro Nacional de Informações Sociais, que a efetiva proteção ao sistema de informações do trabalhador se dá na medida da garantia de que os dados do cidadão sejam inseridos no sistema, temos por certo que a efetividade da necessária tutela se verifica ao se afiançar que o principal veículo de abastecimento desses dados seja corretamente preenchido e tempestivamente enviado.

Como dito alhures, havendo o adimplemento da transmissão da Guia de Informações ao FGTS e à Previdência Social, pela empresa ou pelo equiparado, o sistema de gerenciamento e armazenamento de dados do segurado para a concessão dos benefícios

\footnotetext{
${ }^{352}$ Algumas condutas tributárias descumpridas ensejam até pena privativa de liberdade, como nos casos do artigo 168-A do Código Penal.

353 PAULSEN, Leandro. Denúncia Espontânea da Infração. In MACHADO, Hugo de Brito (Coord.). Sanções Administrativas Tributárias. São Paulo: Dialética, 2004. p.271.
} 
previdenciários se aperfeiçoa, permitindo ao INSS o cumprimento eficiente de seu desiderato.

Aliado ao exposto, não podemos esquecer que outro direito, este trabalhista, mas de inegável função social, o Fundo de Garantia, depende fundamentalmente da GFIP como forma de correta individualização dos depósitos de cada empregado.

Diante dessas considerações, podemos concluir que nossa proposta de tutela efetiva das informações sociais do trabalhador caminha no sentido da garantia do preenchimento e envio da GFIP, ou, no caso de inadimplemento pelo obrigado, da determinação de qual medida é mais eficaz para garantir que os dados do trabalhador sejam enviados ao CNIS.

Cremos que duas esferas de exame da questão devem ser empreendidas. Uma no sentido da fomentação do cumprimento pelo próprio obrigado, no prazo determinado ou mesmo fora dele. Outra, a substituição da responsabilidade pelo envio, sendo certo que esta outra providência deve ser tomada subsidiariamente, ou seja, somente quando constatado que o legalmente obrigado não vai se desvencilhar do dever.

Ao estudarmos as normas instituidoras de sanção encontramos duas funções principais, a repressiva e a preventiva, essa no sentido de coerção ao cumprimento espontâneo da obrigação, em face do temor da pena, e aquela, no caminho da penalização, com o fito de obstar a repetição da falta.

Tendo em mente o notório caráter tributário da GFIP, especificamente de obrigação acessória, e visando encontrar a tutela mais efetiva dentre as possibilidades assentes no ordenamento jurídico, vejamos se as sanções previstas na Lei $\mathrm{n}^{\circ}$ 8.212, de 1991, e na Lei $\mathrm{n}^{\circ} 8.036,{ }^{354}$ de 1990, são compatíveis com as funções objetivas das normas sancionatórias, mormente no campo tributário.

Principiando pela lei do FGTS, podemos observar no artigo 23 , parágrafo $2^{\circ}$, a estipulação de multa punitiva diferenciada para as infrações tipicamente tributárias, como por exemplo, deixar de recolher o tributo $\left(\S 1^{\circ}, \mathrm{I}\right)$, ou alterar sua base de cálculo $\left(\S 1^{\circ}\right.$, IV), ${ }^{355}$ e para as obrigações tipicamente sociais, como no caso da informação incorreta

\footnotetext{
${ }^{354}$ Reiteramos nosso entendimento de que, do ponto de vista da empresa, o FGTS tem caráter tributário, por se enquadrar a perfeição ao conceito de tributo, estatuído no artigo $3^{\circ}$ do CTN. Ver nota n ${ }^{\circ} 222$.

${ }^{355}$ Lei n' ${ }^{\circ} 8.036 / 91$, art. 23. 'Competirá ao Ministério do Trabalho e da Previdência Social a verificação, em nome da Caixa Econômica Federal, do cumprimento do disposto nesta lei, especialmente quanto à apuração dos débitos e das infrações praticadas pelos empregadores ou tomadores de serviço, notificando-os para efetuarem e comprovarem os depósitos correspondentes e cumprirem as demais determinações legais, podendo, para tanto, contar com o concurso de outros órgãos do Governo Federal, na forma que vier a ser regulamentada.

$\S 1^{\circ}$ Constituem infrações para efeito desta lei:
} 
enviada ao CNIS $\left(\S 1^{\circ}\right.$, III). ${ }^{356}$ Não obstante, raciocinando a partir da ótica social do interesse do tributo em questão e recordando que o recolhimento tempestivo do tributo deve ser sempre incentivado, ${ }^{357}$ não se observa na disposição legal nenhum empecilho ao nosso objetivo de uma tutela efetiva das informações sociais.

$\mathrm{Na}$ Lei de Custeio da Previdência Social encontramos, em alteração promovida em 2009, a previsão constante do artigo 35-A, a qual determina que, nos casos de lançamento de ofício, ou seja, nos casos em que o Fisco efetue o lançamento, seja aplicada a regra do artigo 44 da Lei $n^{\circ}$ 9.430, como vimos no item 5.4.1 do presente estudo. Explicitando o feixe normativo, típico emaranhado que a legislação tributária federal insiste em manter e fomentar, devemos entender que, no caso de o Fisco efetuar o lançamento, ou seja, no caso da não homologação do lançamento feito pelo próprio contribuinte, caberá multa punitiva que varia de $75 \%$ a $225 \%$ sobre o valor do tributo devido, dependendo da conduta do sujeito passivo. O valor do menor incremento - falta de declaração ou de declaração inexata - seria aplicável às condutas obrigatoriamente decorrentes de falta de envio da GFIP ou do envio da GFIP com informações incorretas.

Como realçado no item 5.4.1, a finalidade tributária da GFIP, permitir que o Fisco conheça os fatos geradores ocorridos e, portanto, possa mensurar o tributo devido, é protegida ao se cominar pena tão vultosa no caso de descumprimento do dever de prestar as informações corretas por meio da Guia de Informações. Nesse sentido, encontramos, assim como no caso do FGTS, normas sancionatórias compatíveis com as finalidades

I - não depositar mensalmente o percentual referente ao FGTS, bem como os valores previstos no art. 18 desta Lei, nos prazos de que trata o $\S 6^{\circ}$ do art. 477 da Consolidação das Leis do Trabalho - CLT;

II - omitir as informações sobre a conta vinculada do trabalhador;

III - apresentar as informações ao Cadastro Nacional do Trabalhador, dos trabalhadores beneficiários, com erros ou omissões;

IV - deixar de computar, para efeito de cálculo dos depósitos do FGTS, parcela componente da remuneração; V - deixar de efetuar os depósitos e os acréscimos legais, após notificado pela fiscalização.

$\S 2^{\circ}$ Pela infração do disposto no $\S 1^{\circ}$ deste artigo, o infrator estará sujeito às seguintes multas por trabalhador prejudicado:

a) de 2 (dois) a 5 (cinco) BTN, no caso dos incisos II e III;

b) de 10 (dez) a 100 (cem) BTN, no caso dos incisos I, IV e V.

$\S 3^{\circ}$ Nos casos de fraude, simulação, artifício, ardil, resistência, embaraço ou desacato à fiscalização, assim como na reincidência, a multa especificada no parágrafo anterior será duplicada, sem prejuízo das demais cominações legais.' ...

${ }^{356}$ Em acréscimo às multas mencionadas no artigo 23, a Lei do FGTS estipula outras sanções pecuniárias no artigo 22, estas de caráter moratório, portanto, afetas à obrigação tributária principal, obrigação de pagar, e com nítida finalidade de forçar o adimplemento tempestivo da obrigação.

${ }^{357}$ A melhor técnica de arrecadação tributária prega a exigência de uma sanção pecuniária forte como medida incentivadora do recolhimento tempestivo do tributo, pois, se o custo do recolhimento em atraso do tributo for menor que o custo do dinheiro no mercado, as empresas, na menor dificuldade, optarão pela mora tributária devido a seu menor custo. 
tributárias da GFIP, uma vez que são estipulam sanções pecuniárias de monta que iniba o descumprimento da obrigação da prestar informações.

Infelizmente, não se observa o mesmo acuramento da legislação no caso das informações sociais. Não há, como pudemos demonstrar ao longo do presente estudo, medida legislativa que alcance de maneira plena e eficaz a proteção dos dados dos trabalhadores constantes da GFIP e, portanto, a serem necessariamente inseridos no CNIS.

Neste ponto, depois de perquirirmos a teoria sobre as normas instituidoras de sanção, podemos, com a tranquilidade que o somente o conhecimento científico proporciona, assegurar que a falta de proteção eficaz das informações do trabalhador, relativas ao contrato de trabalho por ele desenvolvido, decorre da falta de norma sancionatória positiva. Mais ainda, causa-nos maior indignação, com o perdão da forte manifestação, constatar a ausência da norma premial, promovida pela Lei $n^{\circ} 11.941$, de 2009, que, ao alterar a redação da Lei ${ }^{\circ} 8.212$, de 1991 , revogando os $\S \S 4^{\circ}$ a $8^{\circ}$ do inciso IV do artigo 32, deixou de favorecer o contribuinte que corrigia eficazmente sua falta, embora fora do prazo, e que por isso tinha o direito à redução da penalidade imputada pela lei ao descumprimento de obrigação tributária acessória.

Como construído ao longo do presente trabalho, tal mudança legislativa criou a indesejável situação na qual o contribuinte obrigado ao dever previsto na lei tributária cumpria sua obrigação, inclusive quanto ao pagamento da contribuição social, mesmo após a atuação estatal, não beneficia diretamente o trabalhador para o qual a lei foi criada. Tal fato, esdrúxulo, ocorre porque não houve o envio da informação da vinculação entre o valor recolhido do tributo e a sua destinação. Exemplificando, a contribuição destinada a financiar os benefícios de um dado cidadão foi recolhida, mas não integrará o seu saláriode-contribuição, pois o dever de informar, dever social e tributário, não foi cumprido, mesmo após a fiscalização do agente do Estado competente para tanto.

Evidente a ausência total de proteção do Estado ao cidadão, ao qual ele, por expressa previsão constitucional, deve garantir os benefícios da Previdência Social e que, pasmem, contribuiu para tanto. O Estado não protege e não paga corretamente os benefícios, mesmo arrecadando os valores destinados a esse fim. Por isso, é evidente a necessidade de alteração da legislação de regência da GFIP.

Nesse ponto poderíamos, simplesmente, propugnar pela volta, pela verdadeira 'repristinação' da redação dada ao inciso IV, especificamente aos $\S \S 4^{\circ}$ a $8^{\circ}$, do artigo 32 
da Lei $\mathrm{n}^{\circ}$ 8.212, de 1991 pela Lei $\mathrm{n}^{\circ}$ 9.528, de 1997. Porém, entendemos que se pode aumentar a proteção ao trabalhador, e manter-se uma coerência legislativa sistêmica.

Como tivemos oportunidade de registrar, é inegável que a alteração da redação da Lei de Custeio da Previdência Social decorre do incômodo provocado na Receita Federal do Brasil pelo fato da lei prever relevação total da multa. Esse mal-estar advém do disposto no artigo 138 do CTN, que caracteriza a denúncia espontânea como sendo aquela que, havendo arrependimento eficaz, é promovida antes do início de qualquer procedimento fiscal afeto à matéria.

Não nos filiamos a essa corrente por entendermos que a lei específica pode dispor de maneira diversa ao disposto pela lei geral para beneficiar o contribuinte. Tanto assim é que a nova redação do inciso II do parágrafo $2^{\circ}$ do artigo $32-\mathrm{A}$ prevê relevação da multa desde que esta ocorra no prazo estipulado pela intimação físcal.

Nesse sentido caminha nossa proposta.

Sem nos atermos às formalidades, ${ }^{358}$ pois não são o foco do presente esforço, iremos elencar, explicitando, os requisitos que norma sancionatória premial deverá conter.

Reconhecendo o acerto do diagnóstico de Leandro Paulsen, ${ }^{359}$ reproduzido linhas atrás, entendemos que a sanção positiva deve conter um comando que impulsione a empresa em mora com o dever de informar os dados afetos ao FGTS e às contribuições previdenciárias em GFIP, porém o conteúdo desse comando não deve ser tão benéfico que aponte no sentido de eventual vantagem do inadimplemento da obrigação.

Deve-se considerar também que a GFIP é um documento complexo e de amplo alcance, que carrega um sem número de informações e de situações ensejadoras de informações não tão simples de serem prestadas. Não obstante a eventual dificuldade, cabe à empresa seu preenchimento, sendo tal disposição explicitada tanto na legislação do FGTS, quanto nas relacionadas com as contribuições previdenciárias. ${ }^{360}$

Compatibilizando as duas constatações expostas nos parágrafos anteriores, e lembrando a natureza de obrigação acessória da GFIP, entendemos que o artigo 32-A da Lei de Custeio deve ser alterado com a incorporação de preceito que:

\footnotetext{
${ }^{358} \mathrm{O}$ processo de elaboração de proposta de lei ordinária deve seguir os ditames da Lei Complementar $\mathrm{n}^{\circ} 95$, de 1998, verdadeira norma de estrutura dirigida ao legislador no tocante à missão de elaboração das leis.

359 "É importante estimular o contribuinte ao cumprimento espontâneo, ainda que tardio, das suas obrigações. Isso se faz mediante a desoneração das multas. Benefício maior implicaria desestímulo ao cumprimento tempestivo das obrigações; menos do que isso não teria efeitos." Ver nota 353.

${ }^{360}$ A Instrução Normativa RFB n ${ }^{\circ} 971$, de 2009, preceitua em seu artigo 47, inciso VIII, ser obrigação da empresa informar em GFIP todos os fatos geradores e dados cadastrais previstos no Manual da GFIP. Por seu turno, a Instrução Normativa SIT n 99 , do Ministério do Trabalho, determina em seu artigo 35 que cabe ao empregador a individualização dos dados do empregado na GFIP.
} 
$\checkmark$ Eleve a multa moratória relativa à entrega, de forma escalonada ao longo do tempo, para valores equivalentes ao tributo devido, mesmo que esse esteja integralmente pago.

$\checkmark$ Estipule multa sancionatória equivalente ao valor do tributo, mesmo que esse esteja integralmente pago, no caso de omissão, inexatidão, ou incorreção de dados relativos à remuneração do segurado, condições de trabalho, ou dados que se relacionem com o cálculo das contribuições devidas.

$\checkmark$ Estipule multa sancionatória, equivalente a $5 \%$ do tributo devido no mês da ocorrência, por campo com informações com erros ou omissões não relacionados com os fatos geradores de contribuição previdenciária, limitada a $100 \%$ do tributo devido.

$\checkmark$ Contenha redução das multas moratórias para $1 / 3$ do valor previsto, desde que o envio seja realizado nas condições previstas para a denúncia espontânea eficaz nos termos do CTN.

$\checkmark$ Contenha redução das multas moratórias para metade do valor se a entrega do documento corretamente preenchido ocorrer no prazo de intimação.

$\checkmark$ Contenha redução das multas moratórias para $2 / 3$ do valor previsto se a entrega do documento corretamente preenchido ocorrer no prazo de impugnação do Auto de Infração.

$\checkmark$ Contenha redução das multas punitivas para $1 / 3$ do valor do tributo, mesmo que esse esteja integralmente pago, desde que, dentro do prazo de intimação, seja corrigida a omissão, inexatidão ou incorreção de dados relativos à remuneração do segurado, condições de trabalho ou ainda dados que se relacionem com o cálculo das contribuições devidas.

$\checkmark$ Contenha redução das multas punitivas para metade do valor do tributo, mesmo que esse esteja integralmente pago, desde que, dentro do prazo de apresentação da impugnação do Auto de Infração, seja corrigida a omissão, inexatidão ou incorreção de dados relativos à remuneração do segurado, condições de trabalho ou ainda dados que se relacionem com o cálculo das contribuições devidas. 
$\checkmark$ Contenha redução das multas punitivas para a $2 / 3$ do valor do tributo, mesmo que esse esteja integralmente pago, desde que, dentro do prazo de recurso contra a decisão da DRJ, seja corrigida a omissão, inexatidão, ou incorreção de dados relativos à remuneração do segurado, condições de trabalho ou ainda dados que se relacionem com o cálculo das contribuições devidas.

$\checkmark$ Contenha redução das multas punitivas para $1 / 3$ do valor previsto, desde que corrigidas, no prazo da intimação, as informações com erros ou omissões não relacionadas com os fatos geradores de contribuição previdenciária.

$\checkmark$ Contenha redução das multas punitivas para metade do valor previsto, desde que corrigidas, no prazo da impugnação do Auto de Infração, as informações com erros ou omissões não relacionadas com os fatos geradores de contribuição previdenciária.

$\checkmark$ Contenha redução das multas punitivas para 2/3 do valor previsto, desde que corrigidas, no prazo do recurso contra a decisão da DRJ, as informações com erros ou omissões não relacionadas com os fatos geradores de contribuição previdenciária.

$\checkmark$ Contenha determinação que, nos casos em que o recurso seja apreciado sem que o contribuinte tenha corrigido a GFIP, o AFRFB responsável pela autuação seja notificado a enviar Representação Administrativa ao Ministério do Trabalho e ao Ministério Público do Trabalho, para que esses providenciem, no âmbito das suas competências, a autuação da empresa pelo descumprimento da legislação do FGTS, e para a propositura, se for o caso, de Inquérito Civil para apuração da responsabilidade pelo dano coletivo causado pela empresa no tocante aos benefícios previdenciários devidos aos trabalhadores que a ela prestaram serviços.

Forçoso reconhecer na proposta acima apresentada que, à primeira vista, o dogma da perda da espontaneidade por parte do contribuinte não restou superado. Entendemos em sentido contrário. Ao se recordar que a falta da entrega da GFIP ou mesmo seu envio com omissões ou inexatidões afetas aos fatos geradores de contribuições previdenciárias enseja a multa prevista no artigo 35-A, que, como visto, onera o valor devido pelo contribuinte com um percentual que varia de $75 \%$ a $225 \%$, temos que esses valores não seriam objeto 
da sanção positiva, pois decorrem do lançamento de ofício do tributo e não do descumprimento do dever de prestar informações.

Por fim, em face das competências exclusivas das carreiras de Auditoria Fiscal da União, defendemos a manutenção da competência do Auditor Fiscal da Receita Federal do Brasil para a fiscalização, e se for o caso, consequente autuação do contribuinte pelo descumprimento do dever de enviar a GFIP. Devido à eficiência que existe, em nosso entendimento, nos atos normativos sobre a fiscalização do recolhimento do FGTS na GFIP pelos Auditores Fiscais do Trabalho, inclusive no tocante aos casos de aferição indireta dos valores devido a título de FGTS, propomos a manutenção da legislação aplicável, com a inclusão, entre os procedimentos obrigatórios da fiscalização, da confecção e do envio de representação administrativa à Receita Federal do Brasil quando a GFIP da empresa contiver erros ou omissões relativas aos fatos geradores de contribuições previdenciárias.

Em tempo, devemos salientar que, como dito no conteúdo da proposta esquematizada acima, no caso do obrigado não ter corrigido até o julgamento do recurso, pelo CARF, do Auto de Infração, o AFRFB notificante estaria obrigado ao envio de Representação Administrativa (RA), ao AFT, para fiscalização do cumprimento das normas de recolhimento e informação do FGTS e envio de RA ao Ministério Público do Trabalho, para propositura de inquérito civil para apuração de responsabilidades, se o parquet entender cabível, dado o descumprimento do dever de informação, que ofende direitos coletivos dos trabalhadores.

Aqui, o ponto da responsabilidade subsidiária pelo envio das informações.

Se o MPT, entender cabível e através do estabelecimento de um termo de ajuste de conduta (TAC) com a empresa, obtiver o que a fiscalização da RFB não conseguiu, ou seja, o preenchimento da GFIP pelo obrigado, todo o sistema foi corretamente, embora tardiamente, abastecido. Por outro lado, se o Procurador do Trabalho não encontrar motivos para o estabelecimento do inquérito administrativo, ou se mesmo após a atuação do MPT, a empresa se quedar inerte, caberia ao Procurador do Trabalho determinar que a própria autarquia previdenciária inserisse os dados dos trabalhadores no CNIS, ${ }^{361}$ uma vez que, até aqui, só ela se beneficiou com a atuação de todos os entes estatais mencionados, pois os valores cobrados pela atuação do Fisco Federal serão recebidos pelo INSS.

Alternativamente à atuação do MPT, poder-se-ia ainda, pelo bem da celeridade do procedimento, incluir-se uma previsão legal pela qual o CARF teria competência para

\footnotetext{
${ }^{361}$ Entendemos ser compatível com o ordenamento jurídico tal proposição face ao disposto no artigo 84, incisos III e V, da Lei Complementar $n^{\circ} 75$, de 1993, e na alteração da Lei $n^{\circ} 8.212$ aqui proposta.
} 
notificar o INSS para que, com base no auto de infração lavrado, se inserissem os dados no CNIS.

Ressalte-se que os dados dos trabalhadores e os respectivos salários-decontribuição constariam do Auto de Infração lançado pelo Auditor Fiscal da Receita Federal do Brasil, tornando extremamente simples a inserção dos mesmos no CNIS pelo INSS.

Inegável que, com a adoção das medidas propostas, mesmo que com o peso da demora, os dados das contribuições dos trabalhadores seriam inseridos no Cadastro Nacional de Informações Sociais após todo o esforço dos agentes públicos na exigência do cumprimento, pelo obrigado, do dever de informar. Tal inserção, segundo o modelo proposto, seria incentivada ao máximo no sentido de ser realizada pela empresa. Porém, mesmo no caso de a empresa optar pela sanção pecuniária, descumprindo sua obrigação de fazer, o segurado da Previdência Social aproveitaria o recolhimento das contribuições sociais que influenciam em seu salário-de-contribuição, e, portanto no cálculo de seu salário-de-benefício, graças à atuação do Estado e do emprego de seu poder de polícia.

Efetividade da tutela das informações sociais do trabalhador. Função social cumprida.

\subsection{Proposta para efetiva proteção nos casos de sentença em reclamatória}

Ao esmiuçarmos a execução de ofício pela Justiça do Trabalho, no item 7.5, pudemos observar que a Lei de Custeio da Previdência Social, na cabeça do artigo 43, apresenta preocupação que salta aos olhos: a determinação para que o juiz do trabalho, sob pena de responsabilidade, determine o imediato recolhimento das importâncias devidas à Seguridade Social. Nem uma linha sobre a necessária vinculação do recolhimento com as informações do trabalhador, por força de seu labor, ensejou a contribuição.

Novamente nos deparamos com a questão que mais nos incomoda: o legislador não se preocupa que, mesmo após os agentes públicos agirem, o trabalhador não aproveite o ingresso dos recursos, por ele originados, e só cobrados pelo Estado.

Aqui a efetiva tutela das informações sociais é a medida mais fácil de ser tomada. Basta que os juízes do trabalho determinem o preenchimento e envio da GFIP relativa à 
reclamatória trabalhista. ${ }^{362} \mathrm{O}$ melhor a se acrescentar é que, ao tomar essa simples providência, além de o Juiz do Trabalho dar efetividade social à sua sentença, ele ganhará o apoio da Receita Federal do Brasil na cobrança do valor da contribuição devida, por causa do caráter de confissão de dívida que a Lei de Custeio empresta à GFIP G63 $^{363}$ pacificamente reconhecido pelos tribunais. ${ }^{364}$

Outro ponto a se destacar é que, por óbvio, é mais fácil ao reclamado cumprir uma obrigação de fazer determinada pelo Juiz, do que cumprir, na maioria das vezes, uma obrigação de pagar. Assim, podemos assentar que a efetiva tutela das informações sociais, no caso das reclamatórias trabalhistas, pode ser alcançada somente com a determinação, pelo Juiz do Trabalho responsável pela execução de ofício das contribuições sociais, do preenchimento e envio da respectiva GFIP.

Embora certos da efetividade da medida, pois não se consegue vislumbrar que a ordem judicial de simples obrigação de fazer possa não vir a ser cumprida, e depois de esgotadas todas as determinações judiciais tendentes ao cumprimento da obrigação, entendemos que, em casos extremos nos quais ocorra descumprimento, poderá o Juiz, com base no seu poder de tutela, determinar que o INSS abasteça o Cadastro Nacional de Informações Sociais com os dados cadastrais do trabalhador e do vínculo de trabalho e com todas as demais informações oriundas da sentença trabalhista e relativas às contribuições sociais previdenciárias executadas de ofício.

Tal procedimento subsidiário, também de simples execução por parte da Justiça do Trabalho e por parte do INSS, ${ }^{365}$ garantirá que o trabalhador tenha os efeitos previdenciários decorrentes dos direitos trabalhistas reconhecidos pela Justiça do Trabalho, cabíveis quando do gozo de algum benefício.

\subsection{Proposta para efetiva proteção nos casos de aferição indireta}

No item 7.6 observamos o procedimento de arbitramento do crédito tributário previdenciário com a profundidade necessária para nossa proposta de proteção das

\footnotetext{
${ }^{362} \mathrm{O}$ preenchimento da GFIP referente às reclamatórias trabalhistas deve seguir as determinações constantes do item 8 do Capítulo IV do Manual da GFIP, aprovado pela Instrução Normativa RFB n 880, de 2008.

${ }^{363}$ Art. 32, IV, § $2^{\circ}$ da Lei no 8.212 , de 1991.

${ }^{364}$ Vide STJ: AgRg no Ag 1374936/SP, Rel. Min Humberto Martins, 2T, DJ 13/09/2011, DJe 21/09/11. Disponível em: <www.stj.jus.br.>. Acesso em: 19 nov.2012.

${ }^{365}$ Se o fluxo de informações assumir tal monta que torne necessário adotar procedimentos informatizados o que não acreditamos, pois contamos com o cumprimento da obrigação pelo reclamado - a empresa de processamento de dados da Previdência Social poderá ser instada a elaborar um sistema facilitador da inserção dos dados no CNIS, pelo INSS, a partir das informações oriundas das Varas Trabalhistas.
} 
informações sociais, nos casos em que o Fisco não pode verificar a base de cálculo das contribuições previdenciária incidentes sobre a remuneração auferida pelo trabalhador.

A Instrução Normativa RFB $n^{\circ}$ 971, de 2009, em seu Título VI, que trata dos procedimentos especiais nas atividades fiscais, explicita:

Art. 446. Aferição indireta é o procedimento de que dispõe a RFB para apuração indireta da base de cálculo das contribuições sociais.

Art. 447. A aferição indireta será utilizada, se:

I - no exame da escrituração contábil ou de qualquer outro documento do sujeito passivo, a fiscalização constatar que a contabilidade não registra o movimento real da remuneração dos segurados a seu serviço, da receita, ou do faturamento e do lucro;

II - a empresa, o empregador doméstico, ou o segurado recusar-se a apresentar qualquer documento, ou sonegar informação, ou apresentá-los deficientemente;

III - faltar prova regular e formalizada do montante dos salários pagos pela execução de obra de construção civil;

IV - as informações prestadas ou os documentos expedidos pelo sujeito passivo não merecerem fé em face de outras informações, ou outros documentos de que disponha a fiscalização, como por exemplo:

a) omissão de receita ou de faturamento verificada por intermédio de subsídio à fiscalização;

b) dados coletados na Justiça do Trabalho, Delegacia Regional do Trabalho, ou em outros órgãos, em confronto com a escrituração contábil, livro de registro de empregados ou outros elementos em poder do sujeito passivo;

c) constatação da impossibilidade de execução do serviço contratado, tendo em vista o número de segurados constantes em GFIP ou folha de pagamento específica, mediante confronto desses documentos com as respectivas notas fiscais, faturas, recibos ou contratos.

$\S 1^{\circ}$ Considera-se deficiente o documento apresentado ou a informação prestada que não preencha as formalidades legais, bem como aquele documento que contenha informação diversa da realidade ou, ainda, que omita informação verdadeira.

$\S 2^{\circ}$ Para fins do disposto no inciso III do caput, considera-se prova regular e formalizada a escrituração contábil em livro Diário e Razão, conforme disposto no $\S 13$ do art. 225 do RPS e no inciso IV do art. 47 desta Instrução Normativa.

$\S 3^{\circ}$ No caso de apuração, por aferição indireta, das contribuições efetivamente devidas, caberá à empresa, ao segurado, proprietário, dono da obra, condômino da unidade imobiliária ou empresa corresponsável o ônus da prova em contrário.

$\S 4^{\circ}$ Aplicam-se às contribuições de que tratam os arts. $2^{\circ}$ e $3^{\circ}$ da Lei ${ }^{\circ}$ 11.457, de 2007, as presunções legais de omissão de receita previstas nos $\S \S 2^{\circ}$ e $3^{\circ}$ do art. 12 do Decreto-Lei $n^{\circ} 1.598$, de 26 de dezembro de 1977 , e nos arts. 40, 41 e 42 da Lei $n^{\circ}$ 9.430, de 27 de dezembro de 1996. (grifo nosso)

A redação do artigo 447 da IN RFB n 971 deixa claro que os procedimentos de aferição, como vistos no item 7.5, somente são cabíveis na presença das condições 
elencadas nos quatro incisos em inequívoco rol taxativo. Forçoso, portanto, tecermos nossas propostas de tutela dos interesses dos trabalhadores nesses casos, verificando a possibilidade de compatibilizar esses interesses sociais com o procedimento fiscal excepcional que, veremos, caminham na mesma direção. O inciso I do artigo 447, que utilizaremos como exemplo aplicável aos demais, permite o arbitramento no caso da constatação pelo Auditor Fiscal de que a contabilidade não registra o movimento real relativo ao faturamento, ao lucro, à receita, e, ao que nos atinge diretamente, à remuneração dos segurados. Necessário explicar que tal constatação é realizada por comparação entre os documentos que suportam lançamentos contábeis e os efetivos registros ou ainda documentos que suportam informações que ensejariam lançamento contábil e esse não foi realizado.

O caso previsto no inciso I do artigo 447, a aferição motivada pelo registro contábil incorreto, leva ao arbitramento das remunerações pagas pelo sujeito passivo, pois a falta de suporte dos lançamentos contábeis demonstra que pode não ter havido o reconhecimento de todos os fatos geradores de contribuição previdenciária. Em outras palavras, ou nem todos os trabalhadores constaram dos documentos que a contabilidade registrou (trabalhadores informais), ou nem toda a remuneração foi contabilizada (pagamento por fora), ou as duas situações ocorreram simultaneamente.

Nesse caso, o AFRFB irá eleger um critério, dentre os previstos na norma, pelo qual ele arbitrará a massa salarial compatível com as remunerações típicas do setor, com a atividade e o porte do sujeito passivo e lançará o crédito tributário calculado sobre o valor arbitrado. Importante realçar que, consoante o disposto no artigo 447, $\S 3^{\circ}$, caberá ao sujeito passível o ônus da prova em contrário.

É justamente neste dispositivo que fundamentamos nossa proposta de proteção ao interesse do trabalhador quando o Fisco constitui o crédito tributário previdenciário por arbitramento.

Defendemos, em páginas passadas, na esteira de vários doutrinadores, ${ }^{366} \mathrm{o}$ direito da Fazenda de constituir o crédito tributário por aferição quando o contribuinte não cumpre seus deveres instrumentais ou opta por não apresentar documentos que permitem ao Auditor Fiscal a correta identificação da base de cálculo do tributo. Contudo, não pode, quando cumprido o dever do Estado de exigir o tributo, haver prejuízo do trabalhador, o que acontece quando a ele não se destina a vantagem econômica decorrente do

\footnotetext{
${ }^{366}$ Ver notas 318,319 e 321 do item 7.6.
} 
arbitramento realizado, pois, indubitavelmente, sob pena de nulidade do lançamento tributário, ocorreu o fato gerador, que se verificou ao menos indiciariamente. ${ }^{367}$

O dever de mensurar o quinhão de cada um não pode ser denegado e a GFIP é o instrumento para tanto.

No caso aqui analisado, defendemos ser perfeitamente possível o preenchimento da GFIP pelo contribuinte após o procedimento de aferição indireta.

O contribuinte, parece-nos, pode ter todo interesse nessa atitude.

Como previsto no parágrafo $3^{\circ}$ do artigo 447 da Instrução Normativa RFB $n^{\circ}$ 971/09, cabe ao sujeito passivo o peso da prova contrária ao lançamento tributário por aferição indireta. É dizer que o contribuinte deverá provar que tem os documentos que permitem a verificação do fato gerador, e principalmente, sua quantificação e mais que esses documentos refletem a realidade dos fatos economicamente apreciáveis ocorridos. A experiência mostra, e a jurisprudência ${ }^{368}$ respalda a afirmação, que esse ônus de desconstituir o arbitramento, ou seja, de demonstrar à Administração Tributária que se pode provar e quantificar o fato imponível, se obtém pela comprovação oriunda de diversas fontes, de documentos constituídos de várias formas, todos obviamente com a mesma informação, e que permitem, em face dessa multiplicidade de dados, a circularização das informações constantes da documentação e, portanto sua validação.

Justamente neste sentido, pode ser de grande valia o correto preenchimento e envio de GFIP que contenha os valores suportados pelos recibos assinados pelos trabalhadores, e constantes de folha de pagamento, documentos estes anteriormente não contabilizados, ou registrados de maneira parcial.

Valendo-nos de nossa técnica da sanção positiva, uma alteração normativa ${ }^{369}$ que mencionasse a possibilidade da utilização da GFIP, em face de seu caráter de confissão e de documento público protegido pelo Código Penal $^{370}$ e da validação das informações nela constantes com outros documentos como forma de comprovação dos fatos geradores incorridos, poderia atender à necessidade do Fisco de arrecadar o tributo devido.

\footnotetext{
${ }^{367}$ HARET, Florence. Teoria e Prática das presunções em direito tributário. São Paulo: Noeses, 2010. p. 208.

${ }^{368}$ Cf. STJ (RMS 26964/GO, Rel. Min Castro Meira, 2a T, DJ 19/08/2009, DJe 11/09/2009) Disponível em: <www.stj.jus.br>. Acesso em 19 nov. 2012.

${ }^{369}$ Entendemos ser desnecessária a alteração de ato legal porque a proposta, em tudo e por tudo, assemelha-se ao disposto na alteração da redação do artigo 32-A, constante de nossa proposta efetuada no item 8.4.4.

$370 \mathrm{O}$ artigo 297, § $3^{\circ}$, III, protege as informações constantes da GFIP criminalizando as condutas que inserem informação falsa ou diversa daquela que deveria ter constado, imputando pena de 2 a 6 anos e multa.
} 
Clara a necessidade, nos casos que aqui analisamos, de que o Auditor Fiscal da Receita Federal do Brasil autue a empresa nos termos da nossa proposta de novo conteúdo para o artigo 32-A da Lei de Custeio como meio de indução do contribuinte à confecção e envio da GFIP.

Não obstante o exposto, pode o contribuinte não ter outros documentos que validem sua declaração em GFIP, e nesse caso, não ter interesse, exceto no caso da redução da multa consoante nossa proposta para as novas disposições do mencionado artigo 32-A da Lei ${ }^{\circ}$ 8.212/91. Exatamente por essa consideração que o AFRFB não pode deixar de autuar a empresa pelo lançamento de dados incorretos afetos ao valor do tributo em GFIP.

Mister também não olvidar que, segundo nossas proposições, ainda haverá o método subsidiário ${ }^{371}$ de abastecimento de informações, que, nestes casos de aferição indireta, demandarão do Auditor Fiscal um esforço maior para proporcionalizar o montante das remunerações aferidas entre todos os trabalhadores identificados no procedimento de fiscalização. Todavia, a grandeza social da atitude compensa o esforço.

Todo o exposto é perfeitamente aplicável nos demais casos previstos nos inciso II e IV do artigo 447 da Instrução Normativa RFB $n^{\circ}$ 971, como se pode facilmente deduzir com a simples leitura dos mesmos. Quanto ao inciso III, do citado artigo 447 da IN RFB n ${ }^{\circ}$ 971, que menciona especificamente as obras de construção civil, como tudo em legislação previdenciária que se relacione com esse importante segmento de atividade econômica, teremos que tecer maiores considerações.

\subsubsection{Proposta para efetiva proteção na aferição indireta de obra de construção civil}

A legislação tributária previdenciária possuiu uma complexidade inerente aos fatos economicamente apreciáveis que o legislador, com supedâneo constitucional, elegeu como geradores de contribuição previdenciária: o trabalho humano remunerado sob qualquer vínculo contratual. Existindo uma pluralidade de contratos e de forma de execução e de remuneração deles, e em face do princípio da tipicidade estrita que vige no direito

\footnotetext{
${ }^{371}$ Propugnamos no item 8.4.4 que se, após o prazo de recurso junto ao CARF, a empresa não apresentar a GFIP, o MPT deveria se comunicado, e o MPT, se entender cabível, deverá instaurar Inquérito Civil visando ao preenchimento da GFIP pelo contribuinte. Se mesmo após a atuação do MPT a empresa ainda se quedar inerte, caberá ao Procurador do Trabalho determinar que a própria autarquia previdenciária insira os dados dos trabalhadores no CNIS, uma vez que, até aqui, só ela teve ganho com a atuação de todos os entes estatais mencionados, pois os valores cobrados pela atuação do Fisco Federal serão recebidos pelo INSS. O INSS utilizaria os dados do próprio Auto de Infração para a inserção determinada.
} 
tributário, a Lei de Custeio tem que alcançar e dispor sobre todos os possíveis fatos geradores de contribuição previdenciária, o que leva à complexidade mencionada.

Há um segmento da indústria, de grande apelo social e econômico, no qual essa complexidade da legislação foi exacerbada à enésima potência: a construção civil.

Ao analisarmos o artigo 33 da Lei $n^{\circ} 8.212$, de 1991, no tocante à possibilidade de aferição no segmento da construção civil, encontraremos uma disposição simples, direta, objetiva, qual seja:

$\S 4^{\circ} \mathrm{Na}$ falta de prova regular e formalizada pelo sujeito passivo, o montante dos salários pagos pela execução de obra de construção civil pode ser obtido mediante cálculo da mão de obra empregada, proporcional à área construída, de acordo com critérios estabelecidos pela Secretaria da Receita Federal do Brasil, cabendo ao proprietário, dono da obra, condômino da unidade imobiliária ou empresa corresponsável o ônus da prova em contrário. (grifo nosso)

O Regulamento da Previdência Social, aprovado pelo Decreto ${ }^{\circ}$ 3.048, de 1999, por meio do artigo 235 mantém praticamente a mesma redação da Lei de Custeio quanto à aferição indireta das contribuições previdenciárias na construção civil.

Leitura simples, conclusões idem. Exceto para a Administração Tributária.

Ao verificarmos como a Administração Tributária elegeu, por meio da Instrução Normativa RFB $\mathrm{n}^{\circ}$ 971, de 2009, os critérios de fiscalização, de recolhimento e principalmente de aferição indireta, veremos como o Fisco pode ser criativo. São mais de 73 artigos sobre o tema dispostos no Capítulo IV ${ }^{372}$ dedicado exclusivamente ao segmento, não se incluindo aí mais de 15 artigos relacionados especificamente à construção e afetos à matrícula, retenção e solidariedade. Só o artigo 322, que tem a função de explicitar os conceitos aplicáveis, dando a acepção dos termos empregados, possui 40 incisos e cinco parágrafos.

Por óbvio que não iremos, por não ser o nosso objeto, nos aprofundar no tema. Explicitaremos somente as questões necessárias à perfeita compreensão dos conceitos irmanados aos nossos propósitos.

É extremamente necessário aclarar que, por questões de incapacidade de fiscalização, o procedimento de aferição indireta é padrão de cálculo das contribuições previdenciárias devidas em obra de construção civil erigida por pessoa física. Aqui, temos

372 A Instrução Normativa RFB $\mathrm{n}^{\circ}$ 971, de 2009, inicia seu Título IV - DAS NORMAS E PROCEDIMENTOS APLICÁVEIS À ATIVIDADE DE CONSTRUÇÃO CIVIL - no artigo 322 e termina no 394. 
outra situação onde o interesse fiscal se opõe, sem necessidade alguma, ao interesse social, e às normas trabalhistas.

Se o proprietário ${ }^{373}$ ou dono da obra for pessoa física, para regularizar sua obra deverá necessariamente calcular as contribuições devidas por meio de aferição indireta, em flagrante ilegalidade em face das disposições do CTN e da Lei de Custeio por nós estudadas. $^{374}$

Ao matricular sua obra junto à RFB, através de um número cadastral denominado matrícula CEI, o proprietário ou dono da obra torna-se ciente da necessária aferição indireta das suas contribuições, e, graças a um escalonamento progressivo de alíquotas aplicáveis, ${ }^{375}$ o responsável pela obra, pessoa física, não é estimulado a registrar os trabalhadores empregados na construção, muito embora as contribuições previdenciárias regularmente recolhidas sejam abatidas da aferição que será efetuada. Porém, resta claríssimo que é mais oneroso o pagamento das contribuições mensais sobre toda a mãode-obra empregada do que a aferição, em face do famigerado escalonamento.

Não obstante o efetivo prejuízo trabalhista causado ao obreiro e ao risco quanto à responsabilidade do proprietário, ou dono da obra, por infração à legislação trabalhista, há ainda, no ponto que nos interessa, um desestímulo à entrega da GFIP, com as consequências que já conhecemos.

\footnotetext{
${ }^{373}$ São responsáveis pela obra de construção civil, segundo o artigo 19, II, ‘b’, combinado com o artigo 325 , ambos da IN RFB n ${ }^{\circ}$ 971, o proprietário (aquele que tem o título de propriedade do imóvel), o dono da obra (aquele que tem a posse), e o incorporador (nos termos da Lei $\mathrm{n}^{\circ} 4.591$, de 1964). Havendo contrato de empreitada total entre o proprietário, dono da obra ou incorporador e empresa construtora, esta passa a ser a responsável pela obra de construção civil. (art. 19, II, 'c', combinado com art. 325 da IN RFB n 971).

${ }^{374}$ Tal afirmação quanto à ilegalidade das disposições normativas causa estranheza ao leitor, que, provido de lógica, deve raciocinar no sentido da indagação: sendo flagrantemente ilegal, por que não se insurgem os contribuintes, buscando o Judiciário para que, a partir de centenas de decisões entre as partes não venha a influir na alteração normativa? A resposta é pior que a indagação: o normativo prevê um escalonamento de alíquotas, em função da área da residência, extremamente benéfico e proporcional - as edificações pagam suas contribuições com alíquota de $4 \%$ ao invés dos $20 \%$ usuais, nos primeiros $100 \mathrm{~m}^{2}-$, o que desonera a contribuição de um lado, mas, de outro, não incentiva a formalização da mão-de-obra.

375 IN RFB n 971, Art. 351. A Remuneração da Mão-de-obra Total (RMT) despendida na obra será calculada mediante a aplicação dos percentuais abaixo definidos na proporção do escalonamento por área, sobre o CGO obtido na forma do art. 350, e somando os resultados obtidos em cada etapa:

I - nos primeiros $100 \mathrm{~m} 2$ (cem metros quadrados), será aplicado o percentual de $4 \%$ (quatro por cento) para a obra tipo 11 (alvenaria) e $2 \%$ (dois por cento) para a obra tipo 12 (madeira/mista);

II - acima de $100 \mathrm{~m} 2$ (cem metros quadrados) e até $200 \mathrm{~m} 2$ (duzentos metros quadrados), será aplicado o percentual de $8 \%$ (oito por cento) para a obra tipo 11 (alvenaria) e 5\% (cinco por cento) para a obra tipo 12 (madeira/mista);

III - acima de 200m2 (duzentos metros quadrados) e até 300m2 (trezentos metros quadrados), será aplicado o percentual de $14 \%$ (quatorze por cento) para a obra tipo 11 (alvenaria) e $11 \%$ (onze por cento) para a obra tipo 12 (madeira/mista);

IV - acima de 300m2 (trezentos metros quadrados), será aplicado o percentual de $20 \%$ (vinte por cento) para a obra tipo 11 (alvenaria) e 15\% (quinze por cento) para a obra tipo 12 (madeira/mista).
} 
A inversão dessa situação passa necessariamente pela revisão dessas disposições constantes do normativo.

Não se pode conceber que uma norma estatal possa fomentar, de qualquer forma, o descumprimento de deveres socialmente relevantes, como por exemplo, o cumprimento da legislação trabalhista e previdenciária. ${ }^{376}$ Porém, como dito ao longo do presente capítulo, nosso objetivo é compatibilizar os interesses da Administração Tributária com os interesses sociais envolvidos. Assim, muito embora nos posicionemos contra as disposições normativas mencionadas, entendemos que as alterações abaixo sugeridas são suficientes para a proteção das informações sociais dos trabalhadores que atuam nas obras de construção civil de responsabilidade de pessoa física. Por isso, propomos como necessárias as seguintes alterações da Instrução Normativa RFB n 971, de 2009:

Revogação do inciso II do artigo 354;

$\checkmark$ Alteração da redação do artigo 354, explicitando que o aproveitamento de qualquer recolhimento de contribuição previdenciária será feito com base na remuneração declarada em GFIP enviada anteriormente ao início do procedimento de regularização da obra por aferição indireta;

$\checkmark$ Inserção de um comando, válido tanto para obra de responsabilidade de pessoa física quanto jurídica, que determine que a aplicação das alíquotas escalonadas previstas no artigo 351, da presunção da mão-de-obra constante das notas fiscais de aquisição de concreto usinado e massa asfáltica ${ }^{377}$ e dos redutores de área previstos no artigo $357^{378}$ apenas serão válidos se houver

\footnotetext{
376 Entendemos descabida a disposição do inciso II do artigo 354 abaixo reproduzido, sendo exemplo flagrante do descompromisso da Administração na defesa dos interesses previdenciários do trabalhador:

Art. 354. A remuneração relativa à mão-de-obra própria, inclusive ao décimo terceiro salário, cujas correspondentes contribuições tenham sido recolhidas com vinculação inequívoca à obra, será atualizada até o mês anterior ao da emissão do ARO com aplicação das taxas de juros previstas na alínea "b" do inciso II e no inciso III do art. 402, e aproveitada na forma do art. 353, considerando-se:

I - a remuneração constante em GFIP, com informações específicas para a matrícula CEI, com comprovante de entrega, desde que comprovado o recolhimento das contribuições correspondentes;

II - a remuneração correspondente às contribuições recolhidas mediante documento de arrecadação identificado com a matrícula CEI da obra, não sendo exigida a comprovação de apresentação de GFIP, quando se tratar de obra de construção civil de responsabilidade de pessoa física. ${ }^{377}$ Art. 356, III da IN RFB n 971.

${ }^{378}$ IN RFB n 971, Art. 357. Será aplicado redutor de 50\% (cinquenta por cento) para áreas cobertas e de $75 \%$ (setenta e cinco por cento) para áreas descobertas, desde que constatado que as mesmas integram a área total da edificação, definida no inciso XVII do art. 322, nas obras listadas a seguir:

I - quintal; II - playground; III - quadra esportiva ou poliesportiva; IV - garagem, abrigo para veículos e pilotis; V - quiosque; VI - área aberta destinada à churrasqueira; VII - jardim; VIII - piscinas; IX - telheiro; X - estacionamento térreo; XI - terraços ou área descoberta sobre lajes; XII - varanda ou sacada; XIII - área
} 
entrega anterior ao início do procedimento de regularização da obra por aferição indireta;

$\checkmark$ Inserção de um artigo que determine que os valores da aferição sejam proporcionalizados, relativamente à remuneração auferida, entre os todos trabalhadores que prestaram serviços na obra de construção civil que se está regularizando e que a CND só será emitida após comprovação do envio da GFIP retificadora pelo proprietário, incorporador, ou dono da obra pessoa física ou jurídica que regulariza a construção.

Tais disposições normativas povoarão o CNIS com dados sobre o vínculo e a remuneração, os quais servirão aos trabalhadores que laboraram na obra cujo responsável adimpliu a obrigação tributária principal referente às contribuições previdenciárias devidas pela obra.

Forçoso realçar, para que não restem dúvidas, que as sugestões acima apresentadas se aplicam para a regularização espontânea da obra de construção civil de responsabilidade de pessoa física.

Sendo caso de lançamento de ofício por aferição indireta, ou seja, quando da atuação do Fisco, as mesmas disposições serão aplicadas nos casos em que o contribuinte atenda às intimações do Auditor Fiscal, dado o caráter vantajoso do preenchimento da GFIP. Se não se localizar o responsável ou se este se quedar inerte no tocante às determinações normativas, somente caberão os procedimentos previstos na lei, aplicáveis à aferição indireta em geral.

Devemos esclarecer também, para perfeita elucidação, que as obras de responsabilidade de pessoa jurídica são regularizadas segundo a comprovação do recolhimento das contribuições previdenciárias incidentes sobre a remuneração das pessoas físicas que trabalharam na obra diretamente e com a comprovação da retenção dos $11 \%$ sobre as notas fiscais emitidas pelas empresas que prestaram o serviço mediante cessão de mão-de-obra, ou seja, sobre a denominada mão-de-obra terceirizada. Não havendo comprovação da mão-de-obra empregada, necessariamente por contabilidade regular e formal, nos termos do artigo 328 da Instrução Normativa RFB n ${ }^{\circ} 971 / 09,{ }^{379}$ a

coberta sobre as bombas e área descoberta destinada à circulação ou ao estacionamento de veículos nos postos de gasolina; XIV - caixa d'água; XV - casa de máquinas.

${ }^{379}$ IN RFB n ${ }^{\circ}$ 971/09, Art. 328. O responsável pela obra de construção civil, pessoa jurídica, está obrigado a efetuar escrituração contábil relativa à obra, mediante lançamentos em centros de custo distintos para cada 
regularização da construção se dará por aferição indireta, segundo o disposto no artigo 381 do mesmo diploma legal.

Se houver descumprimento das obrigações acessórias elencadas, a pessoa jurídica deverá regularizar a obra recolhendo o valor das contribuições sociais previdenciárias devidas calculadas por aferição indireta. Nesses casos, e voltando ao ponto que nos interessa no presente estudo, as propostas sugeridas, as propostas gerais de tutela das informações no caso de aferição indireta seriam aplicáveis, uma vez que condizem in totum ao procedimento específico da aferição na obra de construção civil de responsabilidade de pessoa jurídica.

obra própria ou obra que executar mediante contrato de empreitada total, conforme disposto no inciso IV do art. 47, observado o disposto nos $\S \S 5^{\circ}, 6^{\circ}$ e $8^{\circ}$ do mesmo artigo. 


\section{CONCLUSÕES}

Entendemos que a conclusão de um trabalho científico deve ser construída a partir dos resultados dos esforços empreendidos ao longo dos capítulos. Enfrentemos a questão.

Iniciamos analisando as disposições constitucionais sobre os direitos sociais. Pudemos observar a importância emprestada pelo Poder Constituinte aos direitos sociais, posto que constantes dos direitos fundamentais, conforme explicitado no Título II do Diploma Maior. Dentre toda a relevância dos direitos sociais, demos primazia ao Direito do Trabalho, por agregar ao cidadão dignidade decorrente da capacidade de gerar renda e sustentar a si e à sua família pelo trabalho. Ainda, permite ao trabalhador o orgulho do profissionalismo e da construção da riqueza social.

Ao lado do Direito do Trabalho, dentre os demais direitos sociais, abordamos o Direito da Seguridade Social, pela segurança que empresta ao trabalhador, permitindo a ele que se sinta protegido, com o mínimo de dignidade, quando não puder contar com sua força de trabalho. Nesse sentido, da proteção na impossibilidade da prestação da atividade, a Previdência Social, pilar da Seguridade, desponta como garantidora de direitos e efetivadora dos benefícios sociais.

Partindo de uma análise dos dispositivos constitucionais relacionados ao direito do trabalho, e da seguridade social, observamos todo o arcabouço ensejador e protetivo dos direitos sociais esculpidos na Carta. Também percorremos o sistema de Seguridade, perquirindo os princípios e objetivos da Saúde, da Assistência e da Previdência sociais.

Em seguida, fomos ao direito estrangeiro verificar eventuais similitudes e, principalmente, identificar, devidamente contextualizados histórica e socialmente, quais os benefícios previstos, a quem eram destinados e como era assegurado o acesso a eles. Nossa análise foi realizada considerando o Direito Italiano, Espanhol e Português e em todos eles pudemos observar uma característica comum: a informatização na concessão dos benefícios, baseada no dever do empregador de prestar informações de interesse social, assim entendidas aquelas afetas aos trabalhadores, contratos de trabalho e remuneração. Do estudo, podemos destacar que o dever de prestar informações é protegido pelo ordenamento, tutelando-se, assim, o acesso do trabalhador ao sistema previdenciário. 
Nesse ponto, já detentores do conhecimento sobre os preceitos constitucionais sobre o direito do trabalho e da seguridade social e tendo percorrido, mesmo que em rápidas pinceladas, os sistemas de saúde, assistência e previdência, observando todos os benefícios e serviços prestados pela autarquia previdenciária, passamos a conhecer os meandros da concessão dos benefícios previdenciários.

Iniciamos nossa caminhada pela Guia de Informações ao FGTS e Previdência Social (GFIP). Pesquisamos a motivação de seu surgimento, analisamos o veículo legal que a introduziu no direito positivo e seus objetivos. A partir dessas informações, procedemos a uma análise minuciosa do documento de informações, anotando não só os dados afetos aos trabalhadores, no tocante às informações cadastrais e também às relativas ao desenvolvimento do contrato de trabalho, como também as informações referentes à empresa ou ao a ela equiparado. Constatamos, ainda, que esses dados apresentam natureza de ordem cadastral e de natureza tributária, pois remetem aos fatos geradores de contribuição previdenciária de responsabilidade do tomador de serviços, assim entendido o obrigado à prestação das informações em GFIP.

Não podemos olvidar que nosso documento de análise contém informações de todos os segurados da Previdência Social, ou seja, de todas as pessoas físicas que trabalham mediante remuneração para a empresa, independentemente do vínculo jurídico que une o trabalhador à empresa ou ao a ela equiparado, do valor da remuneração percebida do tempo de duração do trabalho, ou ainda, da frequência com que se estabelece nova relação. Todos os trabalhadores, todas as pessoas físicas que trabalham para a empresa, devem constar da GFIP enviada por essa empresa relativa àquela competência, assim entendido o mês de referência da GFIP. E é essa massa de dados que é enviada ao Cadastro Nacional de Informações Sociais (CNIS), o banco de dados que concentra todas as informações sociais dos trabalhadores brasileiros e que permite a concessão dos benefícios previdenciários.

Inteirados sobre o documento de informações de interesse do Fundo de Garantia e da Previdência Social, debruçamo-nos sobre o estudo de sua natureza jurídica com o fito de verificarmos, a partir de sua essência, para quais finalidades se prestava o veículo de informações sociais. Apoiados na lei de sua criação, buscamos as características que permitissem uma correta classificação em busca da inclusão do documento nos institutos jurídicos que nos auxiliassem no encontro da proteção adequada. Desse esforço resultou a constatação da dupla natureza jurídica da GFIP. De um lado, atestamos a inegável natureza 
tributária, pois típica obrigação acessória, uma vez que instituída por lei tributária e com feição de obrigação de fazer, prestar informações, no interesse de arrecadação e fiscalização de um tributo, a contribuição social. Por outro, despontou de nossa análise a natureza social do documento de informações por conter dados relativos à vida profissional do trabalhador e objetivar povoar o banco de informações que permitam ao trabalhador a percepção dos benefícios previdenciários a ele devidos.

Além da cristalina função social e do verdadeiro meio de concretização dos direitos sociais, a GFIP ainda tem por função a individualização dos valores do depósito do FGTS na Caixa Econômica Federal. Por meio da GFIP, os valores depositados pelo empregador são para cada trabalhador são especificados, favorecendo-se, assim, a identificação do quinhão devido a cada um deles, graças à presença dos dados necessários para o depósito do valor correto da indenização trabalhista pelo tempo de serviço, prevista no artigo $7^{\circ}$ da Constituição. Todo o exposto nos permitiu verificar a função social, imposta por lei, da GFIP, o que nos levou a concluir também a natureza de obrigação legal de viés social, afirmando a duplicidade de natureza jurídica da guia de informações.

Identificada a dupla natureza jurídica, partimos para a investigação da proteção prevista pela legislação para o documento de informações sociais e tributárias. Esta duplicidade de essência jurídica, tributária e civil, necessariamente exige uma dupla preocupação quanto ao descumprimento da obrigação. A omissão ou incorreção do documento de informações acarreta distintos efeitos, ou seja, consequências tributárias e sociais, igualmente importantes. Essas decorrem da finalidade de permitir ao Fisco a constatação do lançamento tributário das contribuições sociais e fundiárias, da possibilidade de verificação da correção do lançamento e do objetivo de povoar o CNIS e o FGTS com os dados laborais e previdenciários do segurado que trabalhou para a empresa, a quem se obriga a prestação de informações via GFIP. Assim, a sanção pelo descumprimento da obrigação deve ser efetivada de modo a proteger tanto os interesses tributários quanto os interesses sociais albergados na GFIP.

É justamente nessa visão de dúplice finalidade ofendida, pelo descumprimento total ou parcial da obrigação, que observamos a incoerência do sistema legal posto por força da Lei $\mathrm{n}^{\circ}$ 11.941, de 2009. No caso de eventual descumprimento do dever de prestar as informações via GFIP pelo obrigado, teremos uma sanção. Tendo essa obrigação natureza tributária, sendo classificável como obrigação acessória, podemos inferir que a pena também terá natureza tributária. 
Até 2 de dezembro de 2008, o Auditor Fiscal da Receita Federal do Brasil, ao constatar omissões ou incorreções no preenchimento da GFIP, independentemente do efetivo recolhimento da contribuição devida, autuava a empresa ou obrigado à entrega da GFIP, dependendo do caso, em até $100 \%$ do valor do tributo devido. ${ }^{380}$ É evidente que tal autuação não obstava à constituição de eventual crédito das contribuições devidas.

Ao contribuinte restava demonstrada a importância capital da Guia de Informações ao FGTS e à Previdência Social. Mesmo com as contribuições sociais devidas recolhidas, o contribuinte era autuado no valor do tributo já pago por força da omissão ou incorreção no cumprimento da obrigação acessória. Porém, em inúmeras vezes, ele nada recolhia. Para tanto, bastava que não tivesse cometido a mesma falta nos últimos cinco anos, explicitamente pedisse a relevação da multa e, em até trinta dias da autuação, entregasse nova GFIP corretamente retificada, alimentando, desse modo, o banco de dados sociais.

Ao assim agir, a empresa ou a ela equiparado retificava de maneira eficaz seu erro. O trabalhador nada perdia. Todo o sistema previdenciário ajustava-se após a atuação do Fisco, ou seja, havia a constituição do crédito tributário devido, com a pena legalmente prevista, e com o destinatário dessa fonte de custeio, o trabalhador - segurado obrigatório da Previdência - devidamente identificado em seus dados sociais e seu salário-decontribuição, sua fonte de custeio. Hoje, ao reverso, a sanção imposta pela Lei $n^{\circ}$ 11.941/09 demonstra clara opção pela tutela não das informações sociais constantes da GFIP, e sim da confissão do tributo devido pelo contribuinte.

A pena cominada no lançamento de ofício do crédito tributário não confessado é forte o suficiente para inibir a conduta de sonegação, função típica de uma obrigação tributária acessória, que é a de apurar e informar o tributo devido, e permitir ao Fisco a necessária conferência. Isto porque, no caso de constituição de crédito de contribuição social de ofício, ou seja, após atuação do Auditor Fiscal da Receita Federal do Brasil, o contribuinte, empresa ou a ela equiparado, que sonegue o tributo social é compelido ao pagamento, com multa de ofício de $75 \%, 150 \%$, ou $225 \%$, conforme o caso, em face de sua conduta omissiva ou inexata quanto ao preenchimento e envio da GFIP. ${ }^{381}$ Temos, então, a seguinte situação: o Fisco atua no cumprimento de seu desiderato institucional, o

\footnotetext{
${ }^{380}$ Em 03 de dezembro de 2008 foi editada a Medida Provisória no 449, convertida na Lei no 11.941 , em 27 de maio de 2009, revogou os parágrafos de $4^{\circ}$ a $8^{\circ}$, do artigo 32 da Lei ${ }^{\circ} 8.212$, de 1991 .

${ }^{381}$ Segundo o artigo 35-A da Lei ${ }^{\circ} 8.212 / 91$, no caso de lançamento de ofício a multa será de $75 \%$ quando, por exemplo, o contribuinte de informar o tributo devido, ou o fazer com inexatidão. Esse percentual será dobrado nos casos de fraude, dolo ou simulação. Além disso, os percentuais de $75 \%$ e $150 \%$ serão acrescidos da metade nos casos de não atendimento nos prazos determinados na intimação, pelo contribuinte
} 
contribuinte compulsoriamente paga a contribuição social devida, o Estado arrecada. Os recursos são recolhidos pelo INSS. Todos cumprem seus papéis após a atuação do agente do Estado. Todavia, o trabalhador não tem o resultado da ação estatal revertido em seu proveito, pois o banco de dados do Cadastro Nacional de Informações Sociais não foi alimentado pela GFIP.

Em sentido contrário da legislação tributária caminha a legislação de regência do FGTS. O Auditor Fiscal do Trabalho (AFT), quando em ação fiscal, deverá verificar a regularidade do recolhimento do FGTS pelo obrigado, seja ele do setor urbano ou rural, público ou privado. O que importa ressaltar é que, diversamente das ações fiscais empreendidas pela Receita Federal do Brasil, que privilegiam a constituição do crédito tributário previdenciário em detrimento das informações sociais prestadas pela GFIP, o Ministério do Trabalho não distingue a sanção quanto à finalidade a ser alcançada, aliando os dois procedimentos, pagar o tributo devido e prestar as informações sociais necessárias. A Instrução Normativa MTE $n^{\circ}$ 99, de 23 de agosto de 2012, preceitua em seu artigo 17 que, ao constatar irregularidade, o AFT deverá proceder o levantamento de débito individualizado por empregado, o que garante ao trabalhador o quantum devido a ele, independentemente do valor arrecadado pela atuação do agente fiscal. O Estado age, na defesa do seu interesse, mas principalmente neste caso, age também tutelando o interesse do trabalhador, individualmente considerado.

Constada a insuficiência da proteção prevista pela legislação às informações sociais constantes da GFIP, passamos a conhecer o CNIS, buscando verificar se há realmente uma possibilidade de dano aos interesses do trabalhador no tocante ao seu eventual acesso aos benefícios previdenciários a ele garantidos. Buscamos a história do CNIS, sua origem, seus objetivos, a evolução legislativa que embasou sua evolução estrutural, como ele é alimentado e estruturado, como se inserem, alteram e extraem as informações do trabalhador e qual a proteção que é dedicada ao banco de dados. Enfim, empreendeu-se ao longo do capítulo dedicado ao Cadastro Nacional uma análise sistêmica sobre o CNIS e sua relação com a GFIP e com a concessão dos benefícios previdenciários, objetivando verificar a real necessidade da proteção dos dados ali armazenados e quais as possibilidades de retificação desses dados no caso de eventual interesse do trabalhador.

Comprovada a necessidade de proteção dos dados armazenados pelo CNIS, pois constatada sua imprescindibilidade para a concessão dos benefícios previdenciários devidos ao trabalhador, passamos a verificar a tutela hoje existente. Nessa empreitada, 
observamos que a Lei $n^{\circ}$ 8.212, de 1991, na redação imposta pela Lei $n^{\circ}$ 9.528, de 1997, continha em seu artigo 32, dispositivos que sancionavam a não apresentação do documento de informações e também a apresentação com dados incorretos, mesmo quando houvesse o pagamento do tributo devido.

Claro está o viés protetivo do conteúdo social da GFIP, uma vez que seu aspecto tributário estaria, em tese, superado em face do correto recolhimento existente. Concluímos, até pela existência de outros dispositivos no mesmo artigo 32 da Lei de Custeio, que o legislador havia concebido métodos eficazes de tutela do viés social e tributário da GFIP, pois no caso do inadimplemento de uma obrigação ou de outra pelo sujeito passivo, a norma sancionadora continha dispositivos que, após a atuação dos Agentes Fiscais, corrigia o sistema de informações sociais e permitia a cobrança acrescida de sanção pecuniária do eventual tributo devido.

Porém, alteração promovida pela Lei $\mathrm{n}^{\mathrm{o}} 11.941$, de 2009, portanto posterior à unificação dos Fiscos Federais, ${ }^{382}$ revogou o artigo 32 e introduziu um artigo 32-A na Lei n 8.212, de 1991, que prevê novas penas pecuniárias, como sanção pelo inadimplemento do dever de prestar informações pela GFIP. Caminhando pela trilha do desestímulo ao inadimplemento em face do custo da sanção pecuniária imposta, típica visão tributária sobre a sanção de ato ilícito, a nova redação da Lei de Custeio privilegia sobremaneira o caráter tributário da GFIP, pois, havendo omissão de fatos geradores na GFIP, o contribuinte será onerado com multa variável entre $75 \%$ e $225 \%$, dependendo de condições subjetivas, mas não será compelido ao preenchimento do documento de informações, o que, como amplamente demonstrado, reverbera nas informações dos trabalhadores armazenadas no CNIS. Com isso, há relevantes prejuízos aos trabalhadores na eventual necessidade de amparo previdenciário.

Convencidos da praticidade, operacionalidade, segurança e justiça do sistema de concessão de benefícios concebido a partir da criação do Cadastro Nacional de Informações Sociais, entendemos que a efetividade da tutela dos direitos do trabalhador brasileiro se dá na medida da proteção do sistema tal qual concebido, e nesse diapasão, na proteção da inserção dos dados no CNIS, que se dá, como forma mais importante em face do volume das informações que transmite e da quantidade de segurados que abrange, por intermédio da GFIP. Logo, ao proteger a Guia de Informações, na verdade, ao garantir o cumprimento do dever de prestar as informações sociais, estaremos tutelando o Cadastro

${ }^{382}$ Lei $^{\mathrm{o}} 11.457$, de 2007. 
Nacional de Informações Sociais, e por ele, afiançando o acesso do trabalhador aos benefícios sociais previstos no ordenamento. Constamos assim que, hoje, ou melhor após o advento da alteração que revogou o artigo 32 e introduziu o artigo 32-A na Lei $n^{\circ} 8.212$, de 1991, não há proteção legal aos direitos previdenciários do trabalhador. Tal assertiva se avoluma em injustiça ao se recordar, como demonstramos no capítulo 5, item 5.4, que a tutela penal é mais objetiva, ao tipificar a omissão da informação ou a informação inexata em GFIP, que a própria lei que instituiu o documento de informações.

Observamos também que a ineficácia da proteção à informação social se repete nos casos de aferição indireta das contribuições sociais, e mais importante, na execução de ofício das contribuições sociais incidentes sobre as sentenças e acordos homologados pela Justiça do Trabalho. Quanto aos lançamentos por aferição indireta, repete-se a injustiça da ação fiscal, do agir do Estado, com efetividade na cobrança do tributo, porém sem nenhum retorno social, pois não há o aproveitamento pelo trabalhador daquele arbitramento decorrente de uma omissão no cumprimento de obrigação acessória por parte do contribuinte. Importante realçar que tal omissão não impediu o ingresso dos valores devidos de contribuição social previdenciária, mas como explicitado, sem a devida identificação do trabalhador que deveria ser beneficiado pelo recolhimento tributário.

No caso da execução de ofício pelo Juiz do Trabalho, a injustiça social exsurge de maneira ainda mais flagrante. Há uma reclamatória trabalhista, uma sentença ou acordo homologado pelo qual se determina o pagamento de verbas de natureza remuneratória e, portanto, base de cálculo de contribuição previdenciária. Por força do artigo 114 da Carta, o Juiz do Trabalho executa de ofício, se for necessário, os valores devidos pelo reclamado. Esse os paga. O valor não é informado ao CNIS e não é atribuído como salário-decontribuição do trabalhador, que, como vimos, não tem estes recolhimentos como base de seu salário-de-benefício.

Diante desse quadro, nefasto ao trabalhador e contrário ao Estado Democrático de Direito, passamos a propor uma tutela com efetividade na defesa dos direitos sociais dos trabalhadores que, nos casos por nós estudados, pagaram os tributos que suportam financeiramente esses direitos.

Antes de adentrarmos na proposta de proteção, enfrentamos a questão a quem caberia a implementação das medidas que seriam proposta. Qual categoria de servidor público, ou outro ator social - sindicatos, por exemplo -, teria competência para aplicar a legislação sancionadora do inadimplemento do dever de prestar informação. Concluímos 
serem os Auditores Fiscais da Receita Federal e do Trabalho as autoridades competentes para a verificação do cumprimento das obrigações, os primeiros para os dados afetos à contribuição social e os segundos para os relativos ao FGTS.

Iniciando a construção de nossa proposta de efetiva proteção, perquirimos o conceito de ilícito e de sanção, com especial interesse na análise da questão sobre a efetividade das sanções nas obrigações de fazer, que é o tipo de obrigação ao qual se ajusta o nosso problema. Nesse ponto, deparamo-nos com a teoria da sanção positiva.

Por sanção positiva ou sanção premial entende-se aquela que se relaciona com o conceito de mérito ou de prêmio. É o reconhecimento pelo Estado de que os comportamentos que interessam à Sociedade devem ser fomentados, incentivados. Demonstra a transformação dos ordenamentos jurídicos repressivos por excelência, uma vez que baseados na penalização da conduta indesejada, para os ordenamentos com alguma ênfase na promoção do direito, típico do Estados do moderno Bem-Estar Social, onde há um atuação promocional do Estado na realização dos ideais da sociedade.

Observamos que as técnicas legislativas positivas são mais aperfeiçoadas para observar-se o cumprimento das normas jurídicas, pois influenciam o ânimo do agente, impulsionando-o no sentido buscado pela norma. Em um mundo marcado pelo esforço externo em influenciar a decisão individual, a sanção positiva tem efeitos marcantes no cumprimento dos deveres legais ao se pensar que a sensação de impunidade ante a dificuldade do Estado de verificar a adesão de todas as condutas ao disposto na lei é substituída pelo gozo de vantagem imediata surgida com o cumprimento de disposição normativa.

Em um ordenamento jurídico promocional, o Estado pode atribuir funções típicas ao cidadão, desonerando-se delas, ao menos em parte, e contando com a atuação do particular, mesmo que num primeiro momento contra seus próprios interesses. Constatamos que, com o autolançamento, vivenciamos tal situação no mundo tributário. Neste tipo de ordenamento, além de disposições coercitivas, típicas de uma lei, deve o Estado premiar o cidadão que adimple tempestivamente sua obrigação legal, e não necessariamente renegando seu direito de punir aquele que não agiu em conformidade com a determinação legal.

Ao lado da teoria da sanção premial, identificamos a relevância da denúncia espontânea para nosso problema. Constatamos que, mesmo havendo um inadimplemento no dever legalmente imposto, por vezes, atende melhor ao interesse público uma situação 
em que aquele que reconhece sua omissão espontaneamente a corrige de maneira eficaz, do que ter a sociedade que aguardar toda a movimentação da máquina estatal para que se exija o cumprimento do dever legal, claro que acrescido da sanção previamente determinada.

Embasados nessas premissas teóricas, construímos nossa proposta de alteração da legislação baseada na noção de sanção positiva, como forma de incentivo ao adimplemento da obrigação de abastecer o Cadastro Nacional de Informações Sociais. Esse é o suporte teórico de que precisamos para uma legislação que respalde o veículo das informações sociais nos interesses tributários envolvidos - tanto nos aspectos relativos ao Fundo de Garantia por Tempo de Serviço, quanto nas questões referentes às contribuições sociais previdenciárias - e que proteja, por ser a maior das finalidades da Guia de Informações ao FGTS e à Previdência Social, os dados dos trabalhadores que serão armazenados no CNIS.

Em síntese compatível com os objetivos desta conclusão, podemos dizer que nossa proposta de tutela eficaz é realizada por meio de uma alteração legislativa que comine uma multa moratória pela não entrega da GFIP, escalonada ao longo do tempo, que atinja no máximo o valor do tributo nela contido, mesmo que pago. Ademais, deve ser imputada multa sancionatória equivalente ao valor do tributo, mesmo que esse esteja pago, nos casos de omissão, inexatidão ou incorreção dos dados relacionados aos fatos geradores de contribuição previdenciária. Deve ainda prever multa sancionatória por campo com erro ou omissão que não seja referente aos fatos geradores.

Por fim, e o principal, deve determinar redução dos valores das multas moratórias e punitivas de forma escalonada, dependendo de quando o contribuinte cumprir a obrigação de prestar corretamente as informações. Nesse âmbito, a redução será tanto maior quanto antes seja adimplida a obrigação. Por exemplo, se a obrigação for cumprida antes de iniciada a ação fiscal, a multa será reduzida em $2 / 3$. Também será de forma escalonada, minimizando-se as reduções ao longo do tempo do processo administrativo tributário, reduzindo-se para $1 / 3$ se a obrigação for cumprida dentro do prazo de recurso junto ao Conselho Administrativo de Recursos Fiscais (CARF), contra o acórdão da Delegacia de Recursos e Julgamento (DRJ).

Não obstante nossa confiança na efetividade da sanção premial proposta, mas em face da efetividade plena que a ação estatal deve ter na tutela dos interesses dos trabalhadores, sugerimos que haja previsão para que a lei determine, quando perdurar a omissão do contribuinte, que o CARF comunique ao AFRFB notificante o encaminhamento de Representação Administrativa ao Ministério do Trabalho e Emprego e 
ao Ministério Público do Trabalho para que proponham, no âmbito das suas competências, fiscalizações e inquéritos civis administrativos para apuração do recolhimento do FGTS e do dever de prestar informação social. Por outro lado, se o Procurador do Trabalho não encontrar motivos para o estabelecimento do inquérito administrativo, ou se mesmo após a atuação do MPT, a empresa se quedar inerte, caberia ao Procurador do Trabalho determinar que a própria autarquia previdenciária inserisse os dados dos trabalhadores no CNIS, ${ }^{383}$ uma vez que, até aqui, só ela se beneficiou com a atuação de todos os entes estatais mencionados, pois os valores cobrados pela atuação do Fisco Federal serão recebidos pelo INSS.

Alternativamente à atuação do MPT, poder-se-ia ainda, pelo bem da celeridade do procedimento, incluir-se uma previsão legal pela qual o CARF teria competência para notificar o INSS para que, com base no auto de infração lavrado, se inserissem os dados no CNIS.

Importante ressaltar que observamos no novel Código dos Regimes Contributivos da Segurança Social de Portugal, que entrou em vigor em 1 de janeiro de 2011, disposição similar à proposta acima entabulada em seu artigo 40. Na Codificação, determina-se que podem ser supridas de ofício pela instituição de segurança social competente as informações sociais relativas aos trabalhadores no de a empresa não cumprir o dever de prestar as informações sociais relativas aos trabalhadores ao seu serviço Realçamos também que a legislação espanhola, no artigo 30 da Lei Geral de Seguridade Social, contém sanção premial, representada pelo direito ao novo prazo de recolhimento das cotizações desde que o contribuinte declare o valor devido, incentivando assim o cumprimento, mesmo que tardio, das obrigações de informação.

Convém-nos citar Jose Vida Soria, que sintetiza tudo o que defendemos ao longo do presente estudo:

La relación jurídica de Seguridad Social es, pues, una relación que tiene por contenido la prestación pública, siendo así que las otras son relaciones funcionalmente instrumentales y secundarias respecto de la relación prestacional, y actúan como condicionantes legales del derecho a prestaciones. ${ }^{384}$

\footnotetext{
${ }^{383}$ Entendemos ser compatível com o ordenamento jurídico tal proposição face ao disposto no artigo 84, incisos III e V, da Lei Complementar $n^{\circ} 75$, de 1993, e na alteração da Lei ${ }^{\circ} 8.212$ aqui proposta.

${ }^{384}$ VIDA SORIA, José. et al. Manual de Seguridad Social. $3^{\mathrm{a}}$ ed., Madrid: Tecnos, 2007. p. 235
} 
As alterações legislativas propostas, que entendemos plausíveis, compatíveis com o ordenamento jurídico, respeitadoras de competências legalmente impostas aos diversos órgãos e carreiras envolvidas, foram formuladas a partir das constatações realizadas no presente trabalho. Embasados nos fundamentos jurídicos e fáticos apresentados, nele apuramos o efetivo risco que o trabalhador brasileiro corre ao pleitear um benefício previdenciário ao qual tenha direito, nos casos em que seu empregador não cumpriu o dever de prestar informações em GFIP, seja por mero inadimplemento, por ter sofrido constituição de crédito tributário por aferição indireta, ou ainda por ter sido réu em reclamatória trabalhista.

A permanecer o atual sistema sancionatório ao dever de transmitir a GFIP e assim, abastecer o CNIS, o trabalhador brasileiro estará sendo tolhido em seus direitos sociais mesmo após a punição e cobrança do Estado Brasileiro sobre o inadimplente. Não há, em nosso sentir, maior injustiça contra aquele que é o verdadeiro destinatário das ações Estatais, ainda mais de um Estado que tem por objetivos construir uma sociedade livre, justa e solidária, além de erradicar a pobreza e a marginalização e reduzir as desigualdades sociais, consoante preceitua o artigo $3^{\circ}$, incisos I e III da Constituição da República Federativa do Brasil.

Cabe à comunidade científica encaminhar ao Poder Legislativo o alerta sobre a questão e o pedido para a pronta correção da legislação tributária previdenciária. É isso que pretendemos com nosso trabalho. 


\section{ANEXOS}

\section{I - CÓDIgOS DOS TRABALHADORES NA GFIP, segundo o Manual da GFIP,}

aprovado pela Instrução Normativa RFB no 880 , de 2008.

\begin{tabular}{|c|c|}
\hline Cód. & Categoria \\
\hline 01 & Empregado; \\
\hline 02 & Trabalhador avulso; \\
\hline 03 & Trabalhador não vinculado ao RGPS, mas com direito ao FGTS; \\
\hline 04 & $\begin{array}{l}\text { Empregado sob contrato de trabalho por prazo determinado (Lei n }{ }^{\circ} 9.601 / 98 \text { ), com as } \\
\text { alterações da Medida Provisória } n^{\circ} 2.164-41 \text {, de } 24 / 08 / 2001 \text {; } \\
\text { (ver nota 4) }\end{array}$ \\
\hline 05 & Contribuinte individual - Diretor não empregado com FGTS (Lei nº 8.036/90, art. 16); \\
\hline 06 & $\begin{array}{l}\text { Empregado doméstico; } \\
\text { (categoria utilizada a partir da competência } 03 / 2000 \text { - ver nota } 5 \text { ) }\end{array}$ \\
\hline 07 & $\begin{array}{l}\text { Menor Aprendiz - Lei } \mathrm{n}^{\circ} 11.180 / 2005 ; \\
\text { (ver nota } 8 \text { ) }\end{array}$ \\
\hline 11 & Contribuinte individual - Diretor não empregado e demais empresários sem FGTS; \\
\hline 12 & Demais agentes públicos; \\
\hline 13 & $\begin{array}{l}\text { Contribuinte individual - Trabalhador autônomo ou a este equiparado, inclusive o } \\
\text { operador de máquina, com contribuição sobre remuneração; trabalhador associado à } \\
\text { cooperativa de produção; }\end{array}$ \\
\hline 14 & $\begin{array}{l}\text { Contribuinte individual - Trabalhador autônomo ou a este equiparado, inclusive o } \\
\text { operador de máquina, com contribuição sobre salário-base; } \\
\text { (categoria utilizada até a competência } 02 / 2000 \text { - ver subitem 4.3.1, letra “b”) }\end{array}$ \\
\hline 15 & $\begin{array}{l}\text { Contribuinte individual - Transportador autônomo, com contribuição sobre } \\
\text { remuneração; }\end{array}$ \\
\hline
\end{tabular}




\begin{tabular}{|c|c|}
\hline 16 & $\begin{array}{l}\text { Contribuinte individual - Transportador autônomo, com contribuição sobre salário-base; } \\
\text { (categoria utilizada até a competência } 02 / 2000 \text { - ver subitem 4.3.1, letra "b") }\end{array}$ \\
\hline 17 & $\begin{array}{l}\text { Contribuinte individual - Cooperado que presta serviços a empresas contratantes da } \\
\text { cooperativa de trabalho; } \\
\text { (categoria utilizada a partir da competência } 03 / 2000 \text { - ver subitem 4.3.2, letra “b") }\end{array}$ \\
\hline 18 & $\begin{array}{l}\text { Contribuinte Individual - Transportador cooperado que presta serviços a empresas } \\
\text { contratantes da cooperativa de trabalho; } \\
\text { (categoria utilizada a partir da competência } 03 / 2000 \text { - ver subitem 4.3.2, letra “b") }\end{array}$ \\
\hline 19 & Agente Político; \\
\hline 20 & $\begin{array}{l}\text { Servidor Público ocupante, exclusivamente, de cargo em comissão, Servidor Público } \\
\text { ocupante de cargo temporário; }\end{array}$ \\
\hline 21 & $\begin{array}{l}\text { Servidor Público titular de cargo efetivo, magistrado, membro do Ministério Público e } \\
\text { do Tribunal e Conselho de Contas; }\end{array}$ \\
\hline 22 & $\begin{array}{l}\text { Contribuinte individual - contratado por outro contribuinte individual equiparado a } \\
\text { empresa ou por produtor rural pessoa física ou por missão diplomática e repartição } \\
\text { consular de carreira estrangeiras; } \\
\text { (categoria utilizada a partir da competência } 04 / 2003 \text { - ver subitem 4.3.1, letras “c" e } \\
\text { " } g \text { ") }\end{array}$ \\
\hline 23 & 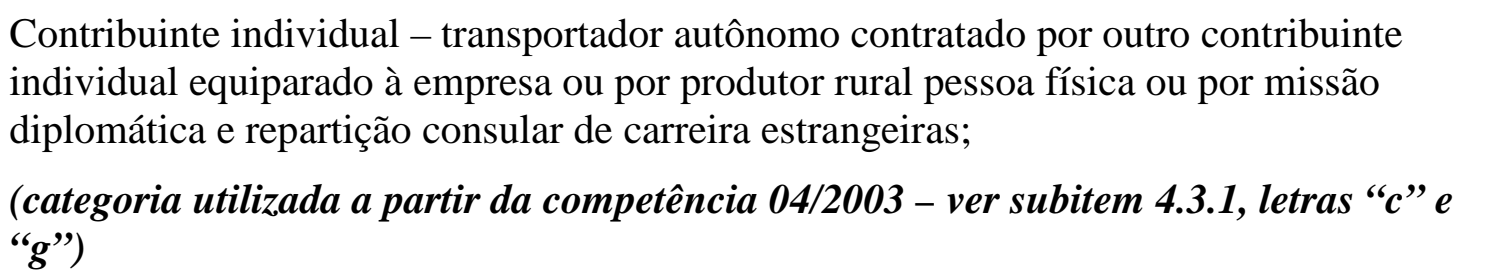 \\
\hline 24 & $\begin{array}{l}\text { Contribuinte individual - Cooperado que presta serviços a entidade beneficente de } \\
\text { assistência social isenta da cota patronal ou a pessoa física, por intermédio da } \\
\text { cooperativa de trabalho; } \\
\text { (categoria utilizada a partir da competência } 04 / 2003 \text { - ver subitem 4.3.2, letra “c”) }\end{array}$ \\
\hline 25 & 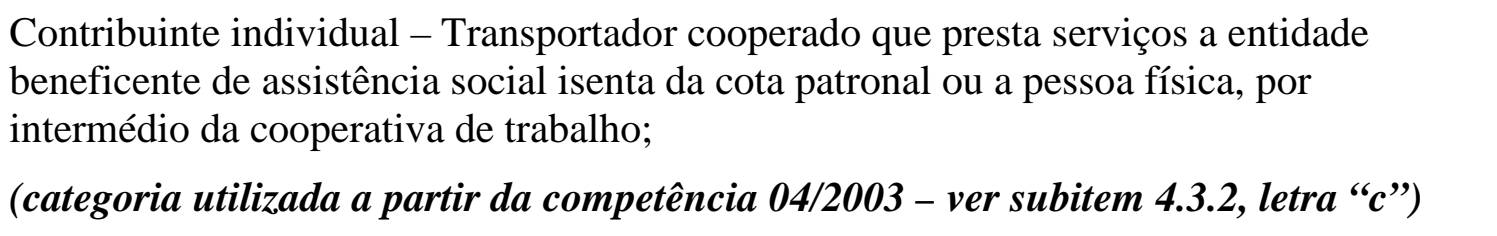 \\
\hline 26 & $\begin{array}{l}\text { Dirigente sindical, em relação ao adicional pago pelo sindicato; magistrado classista } \\
\text { temporário da Justiça do Trabalho; magistrado dos Tribunais Eleitorais, quando, nas três } \\
\text { situações, for mantida a qualidade de segurado empregado (sem FGTS). } \\
\text { (categoria utilizada a partir da versão } 8.0 \text { do SEFIP. Ver nota 6) }\end{array}$ \\
\hline
\end{tabular}

NOTAS: 
1. O trabalhador avulso com vínculo empregatício a prazo indeterminado, registrado no OGMO, cedido a operador portuário em caráter permanente, é considerado segurado empregado, devendo ser informado com a categoria 01 na GFIP/SEFIP do operador portuário.

2. Enquadra-se na categoria 03 o empregado estrangeiro que trabalha no Brasil, com direito ao FGTS, mas vinculado ao regime de previdência do país de origem.

3. O trabalhador que se afastar para prestar serviço militar obrigatório não deve ter seu código de categoria de trabalhador alterado. Entretanto, o código de movimentação "R" deve ser informado durante todo o período de afastamento.

4. Para a categoria 04 (Lei $n^{\circ} 9.601 / 98$ ), até a competência 01/2003, a alíquota do FGTS é de $2 \%$ sobre o valor da remuneração e, a partir da competência 02/2003, a alíquota do FGTS é de $8 \%$ sobre o valor da remuneração.

5. A categoria 06 somente deve ser informada a partir da competência 03/2000, inclusive.

6. A categoria 26 foi criada na versão 8.0 do SEFIP, podendo ser utilizada em qualquer competência, inclusive nas anteriores à data da implantação da referida versão. A categoria 26 substitui a categoria 01 informada em GFIP/SEFIP com código de recolhimento 903.

7. A Lei $n^{\circ} 6.919$, de $02 / 06 / 1981$, em seu art. $1^{\circ}$, faculta ao empregador equiparar o diretor não empregado aos demais trabalhadores sujeitos ao regime do FGTS. Uma vez concedido o benefício, o mesmo deve atingir a totalidade dos diretores não empregados da empresa.

8. Categoria 07 em conformidade com a Lei $\mathrm{n}^{\mathrm{o}} 10.097 / 2000$ até $08 / 2005$. A Lei 11.180/2005 ampliou o limite de idade do menor aprendiz para 24 (vinte e quatro) anos.

\subsection{1 - Contribuintes individuais}

a) A partir da Lei ${ }^{\circ}$ 9.876, de 26/11/1999, os diretores não empregados (categorias 05 e 11), demais empresários (categoria 11) e trabalhadores autônomos (categorias 13 a 18, 22 a 25) receberam a denominação única de contribuinte individual. No entanto, para efeito de enquadramento na tabela de categoria, continua havendo distinção entre contribuintes individuais, respeitando-se as denominações "diretor não-empregado com FGTS (categoria 05), diretor não-empregado e demais empresários sem FGTS (categoria 11), autônomo, transportador autônomo e cooperados (categorias 13 a 18, 22 a 25)", com seus respectivos códigos de categoria, conforme a atividade desenvolvida pelo trabalhador.

b) Em decorrência da revogação da $\operatorname{LC} \mathrm{n}^{\circ}$ 84, de 18/01/96, e das alterações na contribuição da empresa sobre a remuneração dos contribuintes individuais pela Lei ${ }^{\circ}$ 9.876/99, a opção pela contribuição de $20 \%$ sobre o salário-base dos autônomos deixou de existir a partir da competência 03/2000, passando a haver apenas a contribuição de $20 \%$ sobre a remuneração desses trabalhadores. Portanto, as categorias 14 e 16 somente podem ser utilizadas para competências até 02/2000, inclusive. A partir de 03/2000, os trabalhadores informados com categorias 14 e 16 passam a ser informados com categorias 13 e 15, respectivamente, observado o disposto no subitem 4.3.2, letra "b".

c) O contribuinte individual trabalhador autônomo e equiparado ou transportador autônomo, quando contratado por outro contribuinte individual equiparado à empresa 
ou por produtor rural pessoa física ou por missão diplomática e repartição consular de carreira estrangeiras, deve ser informado com as categorias 13,14, 15 ou 16, até a competência 03/2003. A partir da competência 04/2003, deve ser informado com as categorias 22 ou 23.

d) A partir da competência 04/2003, em razão do disposto na Lei $n^{\circ} 10.666 / 2003$, o SEFIP passa a calcular a contribuição descontada dos segurados contribuintes individuais, aplicando a alíquota de $11 \%$ sobre o valor informado no campo Remuneração sem $13^{\circ}$ Salário, para as categorias $05,11,13,15,17$ e 18, já considerando a dedução a que se refere o art. 216, $\S \S 20,21$ e 22, do RPS.

e) Quando a entidade beneficente isenta da cota patronal (FPAS 639) contratar contribuintes individuais diretamente, e informá-los na GFIP/SEFIP com os códigos de categoria 13 ou 15, o SEFIP aplicará a alíquota de $20 \%$ referente à contribuição desses segurados.

f) Quando o contribuinte individual, inclusive o cooperado, presta serviços a entidade beneficente isenta da cota patronal ou a pessoa física, a alíquota referente à contribuição do segurado é de $20 \%$, conforme disposto no art. 216 , $\S \S 26$ e 31 , do RPS, aprovado pelo Decreto $\mathrm{n}^{\circ} 3.048 / 99$, com as alterações do Decreto $\mathrm{n}^{\circ} 4.729$, de 09/06/2003. Por esta razão, os cooperados devem ser informados com as categorias 24 ou 25, na GFIP/SEFIP da cooperativa de trabalho.

g) Para as categorias 22 e 23, não há cálculo da contribuição a cargo do segurado, sendo obrigação do próprio segurado o recolhimento da sua contribuição.

h) As categorias de trabalhador 22 a 25 somente podem ser informadas a partir da competência 04/2003, em decorrência do disposto na Lei $n^{\circ}$ 10.666/2003.

\subsection{2 - Cooperativas de trabalho ou de produção}

a) Os cooperados associados a cooperativa de produção devem ser informados com a categoria 13 (ou 14, até a competência 02/2000), independentemente da competência constante da GFIP/SEFIP.

b) Até a competência $02 / 2000$, os cooperados associados a cooperativa de trabalho devem ser informados em GFIP/SEFIP com as categorias 13, 14, 15 ou 16, conforme o caso. A partir da competência 03/2000, os cooperados que prestem serviços, por intermédio da cooperativa de trabalho, devem ser informados com as categorias 17 ou 18 .

c) A partir da competência 04/2003, os cooperados que prestem serviços a entidade beneficente de assistência social isenta da cota patronal ou a pessoa física, por intermédio da cooperativa de trabalho, devem ser informados com as categorias 24 ou 25 , relativamente à remuneração recebida em decorrência desses serviços, observada a nota do item 3 do Capítulo II.

\subsection{3 - Órgãos públicos}

a) Os contribuintes individuais contratados pela União, Estados, Distrito Federal e Municípios, de acordo com o disposto na Instrução Normativa que dispõe sobre normais gerais de tributação previdenciária e de arrecadação, devem ser informados em GFIP/SEFIP com os códigos de categoria 13, 14, 15 ou 16, conforme o caso.

b) O servidor ocupante de emprego público, regido pela Consolidação das Leis do Trabalho - CLT e vinculado ao Regime Geral de Previdência Social - RGPS, deve ser informado com a categoria 01 . 
c) Enquadram-se como categoria 12, entre outros, o servidor estável por força do art. 19 do Ato das Disposições Constitucionais Transitórias, não-titular de cargo efetivo; o escrevente e o auxiliar contratados antes de 21/11/1994 por titular de serviços notariais e de registro, sem relação de emprego com o Estado.

d) Observado o disposto na Instrução Normativa que dispõe sobre normais gerais de tributação previdenciária e de arrecadação, enquadram-se na categoria 19 o exercente de mandato eletivo federal, estadual, distrital ou municipal, bem como ministros e secretários de Estado, Distrito Federal e Município, desde que não amparados por regime próprio de previdência social, nos termos do art. $10, \S \S 1^{\circ}$ e $3^{\circ}$, do RPS, aprovado pelo Decreto $n^{\circ} 3.048 / 99$ e alterações posteriores.

e) Enquadram-se na categoria 20 o servidor ocupante, exclusivamente, de cargo em comissão declarado em lei de livre nomeação e exoneração, bem como o servidor contratado por tempo determinado, para atender a necessidade temporária de excepcional interesse público, nos termos do inciso IX do art. 37 da Constituição Federal.

f) Enquadram-se na categoria 21 o servidor ocupante de cargo efetivo, conforme previsto no caput do art. 40 da Constituição Federal, desde que, nessa qualidade, não esteja amparado por regime próprio de previdência social, nos termos do art. $10, \S \S 1^{\circ}$ e $3^{\circ}$, do RPS, aprovado pelo Decreto $n^{\circ}$ 3.048/99 e alterações posteriores; o Magistrado e o membro do Ministério Público e Tribunal e Conselho de Contas.

\section{II - QUADRO DOS CÓDIGOS DE MOVIMENTAÇÃO DO TRABALHADOR,} segundo o Manual da GFIP, aprovado pela Instrução Normativa RFB $\mathbf{n}^{\circ} \mathbf{8 8 0}$, de

2008.

\begin{tabular}{|l|l|}
\hline Cód & \multicolumn{1}{|c|}{ Situação } \\
\hline H & Rescisão, com justa causa, por iniciativa do empregador; \\
\hline I1 & $\begin{array}{l}\text { Rescisão sem justa causa, por iniciativa do empregador, inclusive rescisão antecipada } \\
\text { do contrato a termo; }\end{array}$ \\
\hline I2 & Rescisão por culpa recíproca ou força maior; \\
\hline I3 & Rescisão por término do contrato a termo; \\
\hline I4 & $\begin{array}{l}\text { Rescisão sem justa causa do contrato de trabalho do empregado doméstico, por } \\
\text { iniciativa do empregador; }\end{array}$ \\
\hline J & Rescisão do contrato de trabalho por iniciativa do empregado; \\
\hline K & $\begin{array}{l}\text { Rescisão a pedido do empregado ou por iniciativa do empregador, com justa causa, no } \\
\text { caso de empregado não optante, com menos de um ano de serviço; }\end{array}$ \\
\hline L & Outros motivos de rescisão do contrato de trabalho; \\
\hline M & Mudança de regime estatutário; \\
\hline N1 & Transferência de empregado para outro estabelecimento da mesma empresa; \\
\hline N2 & $\begin{array}{l}\text { Transferência de empregado para outra empresa que tenha assumido os encargos } \\
\text { trabalhistas, sem que tenha havido rescisão de contrato de trabalho; }\end{array}$ \\
\hline
\end{tabular}




\begin{tabular}{|c|c|}
\hline N3 & $\begin{array}{l}\text { Empregado proveniente de transferência de outro estabelecimento da mesma empresa } \\
\text { ou de outra empresa, sem rescisão de contrato de trabalho; }\end{array}$ \\
\hline O1 & $\begin{array}{l}\text { Afastamento temporário por motivo de acidente do trabalho, por período superior a } 15 \\
\text { dias; }\end{array}$ \\
\hline $\mathrm{O} 2$ & Novo afastamento temporário em decorrência do mesmo acidente do trabalho; \\
\hline $\mathrm{O} 3$ & $\begin{array}{l}\text { Afastamento temporário por motivo de acidente do trabalho, por período igual ou } \\
\text { inferior a } 15 \text { dias; }\end{array}$ \\
\hline $\mathrm{P} 1$ & Afastamento temporário por motivo de doença, por período superior a 15 dias; \\
\hline $\mathrm{P} 2$ & $\begin{array}{l}\text { Novo afastamento temporário em decorrência da mesma doença, dentro de } 60 \text { dias } \\
\text { contados da cessação do afastamento anterior; }\end{array}$ \\
\hline P3 & Afastamento temporário por motivo de doença, por período igual ou inferior a 15 dias; \\
\hline Q1 & Afastamento temporário por motivo de licença-maternidade (120 dias); \\
\hline Q2 & Prorrogação do afastamento temporário por motivo de licença-maternidade; \\
\hline Q3 & Afastamento temporário por motivo de aborto não criminoso; \\
\hline Q4 & $\begin{array}{l}\text { Afastamento temporário por motivo de licença-maternidade decorrente de adoção ou } \\
\text { guarda judicial de criança até } 1 \text { (um) ano de idade (120 dias); }\end{array}$ \\
\hline Q5 & $\begin{array}{l}\text { Afastamento temporário por motivo de licença-maternidade decorrente de adoção ou } \\
\text { guarda judicial de criança a partir de } 1 \text { (um) ano até } 4 \text { (quatro) anos de idade (60 dias); }\end{array}$ \\
\hline Q6 & $\begin{array}{l}\text { Afastamento temporário por motivo de licença-maternidade decorrente de adoção ou } \\
\text { guarda judicial de criança a partir de } 4 \text { (quatro) anos até } 8 \text { (oito) anos de idade (30 dias); }\end{array}$ \\
\hline $\mathrm{R}$ & Afastamento temporário para prestar serviço militar; \\
\hline $\mathrm{S} 2$ & Falecimento; \\
\hline S3 & Falecimento motivado por acidente de trabalho; \\
\hline $\mathrm{U} 1$ & Aposentadoria; \\
\hline U3 & Aposentadoria por invalidez; \\
\hline V3 & $\begin{array}{l}\text { Remuneração de comissão e/ou percentagens devidas após a extinção de contrato de } \\
\text { trabalho. }\end{array}$ \\
\hline $\mathrm{W}$ & Afastamento temporário para exercício de mandato sindical; \\
\hline $\mathrm{X}$ & Licença sem vencimentos; \\
\hline $\bar{Y}$ & Outros motivos de afastamento temporário; \\
\hline $\mathrm{Z1}$ & Retorno de afastamento temporário por motivo de licença-maternidade; \\
\hline $\mathrm{Z2}$ & Retorno de afastamento temporário por motivo de acidente do trabalho; \\
\hline $\mathrm{Z} 3$ & $\begin{array}{l}\text { Retorno de novo afastamento temporário em decorrência do mesmo acidente do } \\
\text { trabalho; }\end{array}$ \\
\hline $\mathrm{Z4}$ & Retorno de afastamento temporário por motivo de prestação de serviço militar; \\
\hline $\mathrm{Z5}$ & retornos de afastamento temporário e/ou licença; \\
\hline
\end{tabular}



igual ou inferior a 15 dias.

\section{NOTAS:}

1. O salário-maternidade é pago diretamente pelo INSS para os afastamentos de seguradas empregadas, iniciados a partir de 12/1999 e cujos benefícios foram requeridos até 31/08/2003, e de seguradas empregada doméstica, avulsa, especial e contribuinte individual, bem como de segurada que adotar ou obtiver guarda judicial para fins de adoção, qualquer que seja a data do início do afastamento ou do requerimento. A movimentação (códigos Q1, Q2, Q3, Q4, Q5 e Q6) deve ser informada normalmente, bem como a remuneração integral da segurada (paga pelo empregador/contribuinte e/ou INSS). Nos meses em que o pagamento for integralmente efetuado pelo INSS, o empregador/contribuinte é responsável, exclusivamente, pelas contribuições patronais. Já nos meses em que existam valores pagos pela empresa e pelo INSS (afastamento e retorno da segurada no decorrer do mês, por exemplo), a empresa também é responsável pelo desconto e recolhimento da contribuição da própria segurada, referente aos valores pagos pela empresa.

A contribuição da segurada beneficiária do salário-maternidade é descontada pelo próprio INSS, quando do pagamento do benefício. Sendo o afastamento e/ou retorno no decorrer do mês, a empresa deve efetuar o desconto da remuneração da segurada, referente aos dias trabalhados, levando-se em conta a aplicação da alíquota correspondente à remuneração integral (parcela paga pela empresa e paga diretamente pelo INSS).

Quando a remuneração paga pelo empregador/contribuinte, proporcional aos dias trabalhados, e o salário-de-benefício pago pelo INSS, proporcional aos dias de licençamaternidade, nos meses respectivamente de início e fim da licença, atingirem o limite máximo do salário-de-contribuição, não caberá qualquer desconto pela outra parte.

O salário-maternidade pago diretamente pelo INSS não pode ser deduzido pela empresa.

O salário-maternidade das seguradas empregadas, com afastamento iniciado até 11/1999 ou com benefício requerido a partir de 01/09/2003, é pago pelo empregador/contribuinte, constituindo-se em parcela dedutível. Observar o disposto na letra "b" do subitem 4.6.

2. Ocorrendo afastamento de contribuinte individual - diretora não-empregada com ou sem FGTS, em virtude de licença-maternidade, os mesmos códigos de movimentação devem ser utilizados. Entretanto, se não houver qualquer remuneração por parte da empresa durante o período de afastamento, somente haverá contribuição previdenciária a cargo da própria segurada, situação em que a trabalhadora não deve ser informada.

3. Nos casos excepcionais em que o período da licença-maternidade tenha sido aumentado mediante atestado médico específico, deve ser informado o código Q2 e o dia imediatamente anterior à prorrogação da licença.

4. Tanto no parto quanto no aborto não criminoso, na adoção ou na guarda judicial, o retorno deve ser registrado com a data do último dia da licença, e o código Z1. 
5. Nos casos de afastamento por acidente de trabalho (inclusive prorrogação), serviço militar obrigatório e licença-maternidade, os códigos e datas de movimentação devem ser informados em todos os meses enquanto durar o afastamento. Quando se tratar de acidente do trabalho ou serviço militar obrigatório, também deve ser informada a base de cálculo das contribuições à Previdência Social no campo Base de Cálculo da Previdência Social. Este campo pode ter valor igual a zero nos casos de ausência do fato gerador, como por exemplo, nos meses intermediários entre o afastamento e o retorno do acidente do trabalho ou do serviço militar obrigatório.

6. Sempre que houver a informação de uma movimentação de retorno, devem ser informados, também, o código e a data de afastamento.

7. Nos códigos 150 e 155, as movimentações definitivas H, I1, I2, I3, J, K, L, S2, S3, U1, e as temporárias O1, O2, Q1, Q2, Q3 Q4, Q5, Q6, R, Z1, Z2, Z3 e Z4 devem ser informadas em todos os tomadores/obras a que o trabalhador estiver vinculado, quando ocorrer a movimentação.

8. Para os contribuintes individuais enquadrados nas categorias 05 e 11, afastados por motivo de doença, a partir da competência 12/1999, não deve ser informada a remuneração referente aos 15 primeiros dias de afastamento, que deve ser paga pelo INSS, em decorrência da Lei n ${ }^{\circ}$ 9.876/99.

9. O afastamento de servidor público do órgão de origem para prestação de serviços a outro órgão deve ser informado na GFIP/SEFIP do órgão de origem com o código de movimentação Y.

10. Caso o aposentado pelo RGPS que permaneça em atividade sujeita a este regime, ou a ele retorne, se afaste do trabalho por motivo de doença ou acidente do trabalho, o campo Movimentação deve ser informado com os códigos indicativos de tais afastamentos, ainda que o trabalhador não faça jus ao benefício de auxílio-doença (previdenciário ou acidentário) de forma cumulativa com a aposentadoria (art. 18, $2^{\circ}$, da Lei $\left.n^{\circ} 8.213 / 91\right)$.

11. No caso de transferência de trabalhadores, os códigos de movimentação N1, N2 e N3 devem ser informados inclusive para os trabalhadores afastados por motivo de acidente de trabalho, serviço militar obrigatório e licença-maternidade.

12. Caso o trabalhador se afaste por motivo de doença ou acidente do trabalho, por período até 15 dias (códigos O3 ou P3), e volte a se afastar dentro de 60 dias do retorno do afastamento anterior, nos termos da Instrução Normativa que estabelece critérios a serem adotados pela Área de Benefício, é responsabilidade da empresa o pagamento da remuneração referente apenas aos dias que faltam para completar o período de 15 dias. Exemplo:

Empregado, com remuneração mensal de $R \$ 500,00$, se afastou por motivo de doença em 05/04/2004, retornando ao trabalho em 15/04/2004. Voltou a se afastar, por motivo da mesma doença, no período de 12/05/2004 a 31/05/2004.

Na GFIP/SEFIP da competência abril, informar:

- campo Remuneração sem $13^{\circ}$ Salário - valor correspondente à remuneração mensal, incluindo o valor referente aos 10 dias de afastamento - $R \$ 500,00$;

- campo Movimentação - 04/04/2004 (dia imediatamente anterior ao efetivo afastamento) e o código P3 (o afastamento foi inferior a 15 dias); 
- campo Movimentação - 14/04/2004 (último dia da licença) e o código Z5;

- os demais campos devem ser informados de acordo com as instruções deste Manual.

Na GFIP/SEFIP da competência maio, informar:

- campo Remuneração sem $13^{\circ}$ Salário - valor correspondente aos 11 dias trabalhados mais os 5 dias de afastamento, a cargo do empregador - $R \$ 266,67$;

- campo Movimentação - 11/05/2004 (dia imediatamente anterior ao efetivo afastamento) e o código Pl;

- campo Movimentação - 31/05/2004 (último dia da licença) e o código Z5;

- os demais campos devem ser informados de acordo com as instruções deste Manual.

13. Nos casos de rescisão de contrato de trabalho, não havendo saldo de salário ou $13^{\circ}$ salário a informar, em decorrência de faltas ou afastamento temporário, é necessário informar R\$ 0,01 nos campos Remuneração sem $13^{\circ}$ Salário e Base de Cálculo $13^{\circ}$ Salário da Previdência Social, para enviar a informação da movimentação definitiva.

14. O código de movimentação $\mathrm{N} 2$ deve ser informado pelo estabelecimento que transferir o trabalhador, com a data do dia imediatamente anterior à efetiva transferência.

15. O código de movimentação $\mathrm{N} 3$ deve ser informado pelo estabelecimento que recebe o trabalhador transferido, com a data da efetiva transferência. A data de admissão a ser informada no novo estabelecimento deve ser a mesma informada no estabelecimento anterior, em virtude de não ter havido rescisão de contrato de trabalho.

16. O código de movimentação V3 deve ser utilizado quando a legislação permitir efetuar recolhimentos à Previdência e/ou ao FGTS após o encerramento de vínculo. A data de movimentação deverá corresponder ao último dia do vínculo. 


\section{BIBLIOGRAFIA}

ABRAMOVICH, Victor; COURTIS, Christian. Los derechos sociales como derechos exigibles. Madrid: Editorial Trotta, 2002.

ALEXY, Robert. Teoria de los derechos fundamentales. Madrid: Centro de Estudios Constitucionales, 1993.

ALONSO OLEA, Manuel; Alonso García, Rosa Ma. Derecho procesal del trabajo. 15. ed. Madrid: Civitas, 2008.

ALVES, Emérson José; LOPES, Mônica Sette (Coord.). Execução previdenciária na Justiça do Trabalho: aspectos jurisprudenciais e doutrinários. Belo Horizonte: Del Rey, 2003.

ANDRADE, José Carlos Vieira de. Os direitos fundamentais na constituição portuguesa de 1976. 3. ed. Coimbra: Almedina, 2005.

ANDRADE FILHO, Edmar Oliveira. Infrações e Sanções Tributárias. São Paulo: Dialética, 2003.

ANJOS FILHO, Roberio Nunes dos. Direitos fundamentais e hermenêutica constitucional. Revista dos Mestrandos em Direito Econômico da UFBA, Salvador, n. 7, p. 293-330, jan./dez. 1999.

ARCO TORRES, Miguel Ángel del; ARCO BLANCO, Ana Isabel del. Diccionário Básico Jurídico. 7. ed, Granada: Comares Editorial, 2009.

ATALIBA, Geraldo. Hipótese de incidência tributária. 6. ed. São Paulo: Malheiros, 2000. 
ÁVILA, Humberto Bergmann. Teoria dos princípios: da definição à aplicação dos princípios jurídicos. 2. ed. São Paulo: Malheiros, 2003.

BACHOF, Otto. Normas constitucionais inconstitucionais? Coimbra: Almedina, 1994.

BALERA, Wagner. Sistema de seguridade social. 4. ed. São Paulo: LTr, 2006.

. (Coord.). Comentários à declaração universal dos direitos do homem. Brasília: Fortium, 2008.

Previdência social comentada - lei $\mathrm{n}^{\circ} 8.212 / 91$ e lei $\mathrm{n}^{\circ}$ 8.213/91. São Paulo:

Quartier Latin, 2008.

BARRETO, Paulo Ayres. Contribuições: regime jurídico, destinação e controle. São Paulo: Noeses, 2006.

BARROS, Alice Monteiro de. Curso de direito do trabalho. 2 ed. São Paulo: LTr, 2006.

BARROS, Sérgio Rezende de. Direitos humanos. Paradoxo da civilização. Belo Horizonte: Del Rey, 2003.

BARROSO, Luís Roberto. Interpretação e aplicação da constituição. 5. ed. São Paulo: Saraiva, 2003.

BASTOS, Celso Ribeiro. Hermenêutica e interpretação constitucional. 3. ed. São Paulo: Celso Bastos, 2002.

Peculiaridades justificantes de uma hermenêutica constitucional. Cadernos de Direito Constitucional e Ciência Política, São Paulo, v. 5, n. 21, p. 40-53, out./dez. 1997.

BELTRAN, Ari Possidonio. Direito do trabalho e direitos fundamentais. São Paulo: LTr, 2002.

BIM, Eduardo Fortunato. Inconstitucionalidade da execução das contribuições previdenciárias pela justiça do trabalho: EC 20/98. Revista de Direito Tributário, São Paulo, n. 89, p. 21-34, 2003.

BOBBIO, Norberto. A era dos direitos. 4. ed. Rio de Janeiro: Elsevier, 2004.

Contribuición a la Teoria del Derecho. Madrid: Debate, 1990. p. 38.

BOllmanN, Vilian. PREVIDÊnCIA E JUSTIÇA: O Direito Previdenciário no Brasil sob o Enfoque da Teoria da Justiça de Aristóteles. Curitiba: Juruá, 2009.

BULGUERONI, Renata Orsi. Parassubordinação: Origens, Elementos, Espécies e Tutela. in MANNRICH, Nelson (coord). Reforma do Mercado de Trabalho: A experiência Italiana. São Paulo: LTr. 2010.

CARVAlHO, Paulo de Barros. Curso de direito tributário. 19. ed. São Paulo: Saraiva, 2007. 
Saraiva, 2008.

Direito tributário: fundamentos jurídicos da incidência. 6. ed. São Paulo: Direito tributário: linguagem e método. 1. ed. São Paulo: Noeses, 2008.

CASTILHO, Paulo César Bária de. Crédito tributário sem lançamento e execução de ofício da contribuição previdenciária pela justiça do trabalho. Revista Dialética de Direito Tributário, São Paulo, n. 89, p. 58-70, 2003.

CASTRO, Carlos Alberto Pereira de; LAZZARI, João Batista. Manual de Direito Previdenciário. 8. ed. Florianópolis: Conceito Editorial, 2007.

CENTRO DE ESTUDOS FINANCEIROS, Gabinete Jurídico del. Lecciones de Seguridad Social. Madrid: Ediciones CEF. 2011.

CESARINO JR, A. F. Direito Social Brasileiro. 6ª ed. São Paulo: Editora Saraiva, 1970.

CICHON Michael; SCHOLZ Wolfgang; VAN DE MEERENDONK Arthur; AGEMEJER Krzysztof; BERTRANOU Fabio e PLAMONDONl Pierre. Financiación de la protección social. Madrid: Ministerio de Trabajo y Asuntos Sociales, OIT, 2006.

CINELLI, Maurizio. Il rapporto previdenziale. 4. ed. Torino: G. Giappichelli Editore, 2007.

CINTRA, Antonio Carlos Araújo; GRINOVER Ada Pellegrini; DINAMARCO, Cândido Rangel. Teoria geral do processo. 21. ed. São Paulo: Malheiros, 2004.

COELHO, Sacha Calmon Navarro. Infração Tributária e Sanção. 'in' MACHADO, Hugo de Brito (coord). Sanções Administrativas Tributárias. São Paulo: Dialética, 2004.

COIMBRA, J. R. Feijó. Direito previdenciário brasileiro. 7. ed. Rio de Janeiro: Edições Trabalhistas, 1997.

COMPARATO, Fábio Konder. A afirmação histórica dos direitos humanos. 2. ed. São Paulo: Saraiva, 2001.

CONCEIÇÃO, Apelles J. B., Segurança Social: Manual Prático. $8^{\text {a }}$ ed., Coimbra: Almedina. 2008.

CORREIA, Marcos Orione Gonçalves. Teoria geral do processo. 17. ed. São Paulo: Malheiros, 2001.

; CORREIA, Erica Paula Barcha. Curso de seguridade social. 4. ed. São Paulo: Saraiva. 2008.

COSTA, Newton C. A. da. O conhecimento científico. São Paulo: Discurso Editorial, 1997. 
DALLARI, Dalmo de Abreu. Elementos de teoria geral do estado. 11. ed. São Paulo: Saraiva, 1985.

DELGADO, Mauricio Godinho. Curso de direito do trabalho. 4. ed. São Paulo: LTr, 2005.

DI PIETRO, Maria Sylvia Zanella. Direito Administrativo. $14^{\text {a }}$ ed. São Paulo: Atlas, 2002.

ESCANFELlA, Carlos Augusto; TOLOY, Renato David. Execução das contribuições previdenciárias. Revista do TRT da 13 ${ }^{\text {a }}$ Região, João Pessoa, p. 94-102, 1999.

FELICIANO, Guilherme Guimarães. Execução de contribuições sociais na justiça do trabalho. São Paulo: LTr, 2002.

FERRAGUT, Maria Rita; NEDER, Marcus Vinicius. Responsabilidade Tributária. São Paulo: Dialética, 2007.

FERRÃO, João. Entender o actual processo de «terciarização»: das teses às dúvidas. Análise Social. Disponível em r http://analisesocial.ics.ul.pt/documentos/1223031386S1wGH8bg2Bw91DJ6.pdf>. Acesso em: 12 jan. 2010.

FERRARI, Irany et al. História do trabalho, do direito do trabalho e da justiça do trabalho. São Paulo: LTr, 2002.

FERRAZ JÚNIOR, Tércio Sampaio. A ciência do direito. São Paulo: Atlas, 1980.

.Teoria da Norma Jurídica. 3. ed. Rio de Janeiro: Forense, 1987.

FERREIRA FILHO, Manoel Gonçalves. Direitos humanos fundamentais. São Paulo: Saraiva, 2004.

FREITAS, Juarez. O intérprete e o poder de dar vida à constituição. Revista da Faculdade de Direito Universidade Federal do Paraná, Curitiba, v. 32. N. 34, p. 59-76, 2000.

GALANTINO, Luisa. Diritto del lavoro. 15. ed. Torino: G. Giappichelli Editore, 2008.

GIUDICE, F del; MARIANI, Federico; SOLOMBRINO, Mariarosaria. Legislazione e Previdenza Social: Manuale Teorico Pratico. 21 a ed. Napoli: Simone. 2008.

GOMES, Orlando; GOTTSCHALK, Élson. Curso de direito do trabalho. Rio de Janeiro: Forense, 1998.

GORELLI HERNÁNDEZ, Juan; RODRÍGUEZ RAMOS, Maria José; VÍLCHEZ PORRAS, Maximiliano. Sistema de seguridad social. 10. ed. Madrid: Tecnos, 2008.

GRANDI, Gaetano Zilio. Diritti sociali e diritti nel lavoro. Torino: Giappichelli, 2006. 
GRAU, Eros Roberto. Ensaio e discurso sobre a interpretação/aplicação do direito. São Paulo: Malheiros, 2002.

GUADAGNINO, Angelo. Il processo previdenziale in materia contributiva. Padova: Cedam, 2008.

HARET, Florence. Teoria e Prática das presunções em direito tributário. São Paulo: Noeses, 2010.

HOVARTH Jr. Miguel. Direito previdenciário. 7. ed. São Paulo: Quartier Latin, 2008.

IANNIRUBERTO, Giuseppe. Il processo del lavoro rinnovato. Padova: Cedam, 1999.

IBRAHIM, Fábio Zambite. Curso de direito previdenciário. $16^{\mathrm{a}}$ ed. Niterói: Ed. Impetus, 2011.

JORGE NETO, Franciso F. e CAVALCANTE, Jouberto de Quadros P. Direito do Trabalho. Rio de Janeiro: Lumem Iuris Ed., 2005.

JUCÁ, Francisco Pedro. A constitucionalização dos direitos dos trabalhadores e a hermenêutica das normas infraconstitucionais. São Paulo: LTr, 1997.

KELSEN, Hans. Teoria pura do direito. 7. ed. São Paulo: Martins Fontes, 2006.

KONKEL JR, Nicolau. Contribuições sociais. Doutrina e jurisprudência. São Paulo: Quartier Latin, 2005.

LEITE, Carlos Henrique Bezerra. Curso de direito processual do trabalho. São Paulo: LTr, 2003.

LIMA, Maria da Glória Rocha. Execução das contribuições previdenciárias pela justiça do trabalho. Belo Horizonte: Presidência da TRT $3^{\text {a }}$ região, 2004.

LOMBARDI, André Luis Mársico. A importância da execução de ofícios das contribuições previdenciárias no processo do trabalho. Dissertação de mestrado, Faculdade de Direito da Universidade de São Paulo, São Paulo, 2012.

MACHADO, Hugo de Brito. Lançamento tributário e sentença judicial. Revista Dialética de Direito Tributário, São Paulo, n. 64, p. 91-98, 2001.

.Curso de Direito Tributário. 20. ed. São Paulo: Malheiros Editores, 2002.

(Coord.). Sanções Administrativas Tributárias. São Paulo: Dialética, 2004.

MAIOR, Jorge Luiz Souto. Temas de processo do trabalho. São Paulo: LTr, 2000.

Relação de emprego e direito do trabalho: no contexto da ampliação da competência da justiça do trabalho. São Paulo: LTr, 2007. 
Convenção 158 da OIT. Dispositivo que veda a dispensa arbitrária é autoaplicável. Disponível em: 〈http://jus.uol.com.br/revista/texto/5820/convencao-158-da-oit>. Acesso em: 25 jun. 2011.

MALLET, Estevão. Direito, trabalho e processo em transformação. São Paulo: LTr, 2005.

MANNRICH, Nelson. Legislação trabalhista: garantias de patamares mínimos. In ROMAR, Carla Teresa Martins; SOUSA, Otávio Augusto Reis de. (Org.). Temas Relevantes de Direito Material e Processual do Trabalho - Estudos em homenagem ao Professor Pedro Paulo Teixeira Manus. São Paulo: LTr, 2000.

MARTINEZ, Pedro Romano et al. Código do trabalho anotado. 2. ed. Coimbra: Almedina, 2004.

Direito do trabalho. 3. ed. Coimbra: Almedina, 2006.

MARTINS, Alcides. Legislação da Segurança Social: Tomo II, Código dos Regimes Contributivos do Sistema Previdencial de Segurança Social. Lisboa: DisLivro. 2011

MARTINS, Marcelo Guerra. Impostos e contribuições federais. Rio de Janeiro: Renovar, 2004.

MARTINS, Sérgio Pinto. Direito da seguridade social. 24. ed. São Paulo: Atlas, 2007.

Direito do trabalho. 23. ed. São Paulo: Atlas, 2007.

Comentários à CLT. 12. ed. São Paulo: Atlas, 2008.

Comentários às súmulas do TST. 5. ed. São Paulo: Atlas, 2008.

Direitos fundamentais trabalhistas. 1. ed. São Paulo: Atlas, 2008.

.Direito processual do trabalho. 28. ed. São Paulo: Atlas, 2008.

Execução da contribuição previdenciária na justiça do trabalho. 3. ed. São Paulo: Atlas, 2008.

MAXIMILIANO, Carlos. Hermenêutica e aplicação do direito. 9. ed. Rio de Janeiro: Forense, 1979.

MEIRELLES, Edilton. Temas da execução trabalhista. São Paulo: LTr, 1998.

MEIRELLES, Hely Lopes. Direito Administrativo Brasileiro. 38. ed. São Paulo: Malheiros Editores, 2012.

MELO, José E. Soares de. Contribuições sociais no sistema tributário. 5. ed. São Paulo: Malheiros, 2006. 
MELLO, Celso Antônio Bandeira de. Curso de direito administrativo. 12. ed. São Paulo: Malheiros, 2000.

MENDES, Gilmar Ferreira. Controle de constitucionalidade: hermenêutica e revisão de fatos e prognoses legislativos pelo órgão judicial. Revista dos Tribunais, São Paulo, v. 88, n. 766, p. 11-28, ago. 1999.

Hermenêutica constitucional e direitos fundamentais. 1. ed. Brasília: Brasília Jurídica, 2002.

MONTOYA MELGAR, A. Derecho del trabajo. 19. ed. Madrid: Tecnos, 1998.

. (Dir.). Curso de seguridad social. 3. ed. Madrid: Thomson-Civitas, 2005.

MORAES, Alexandre de. Direitos humanos fundamentais. 5. ed. São Paulo: Atlas, 2003.

MOREIRA, José Carlos Barbosa. Comentários ao código de processo civil. 11. ed. Rio de Janeiro: Forense, 2004.

NASCIMENTO, Amauri Mascaro. Curso de direito do trabalho. 17. ed. São Paulo: Saraiva, 2001.

. Dispensas Individuais. Reconstrução do Direito do Trabalho. In: ACADEMIA NACIONAL DE DIREITO DO TRABALHO, 2010, São Paulo. Anais... São Paulo: LTr, 2010.

NERY JUNIOR, Nelson. Princípios fundamentais - teoria geral dos recursos. 5. ed. São Paulo: Revista dos Tribunais, 2000.

Princípios do processo civil na constituição federal. 6. ed. São Paulo: Revista dos Tribunais, 2000.

NERY JUNIOR, Nelson; NERY, Rosa Maria de Andrade. Código de processo civil comentado e legislação processual civil extravagante em vigor. 6. ed. São Paulo: Revista dos Tribunais, 2002.

OLIVEIRA, Fabrício Lopes. O instituto da decadência e os créditos tributárioprevidenciários constituídos na justiça do trabalho. Dissertação de mestrado em direito, Pontifícia Universidade Católica, São Paulo, 2006.

PASSARELLI, Giuseppe Santoro. Diritto e processo del lavoro e della previdenza sociale - Il lavoro privato e pubblico. 4. ed. Milano: Ipsoa, 2006.

PAULSEN, Leandro. Contribuições. Custeio da seguridade social. Porto Alegre: Livraria do Advogado, 2007.

Direito Tributário: Constituição e Código Tributário à Luz da Doutina e da Jurisprudência. Porto Alegre: Livraria do Advogado, 2009.

PERSIANI, Mattia. Diritto della previdenza sociale. $16^{\text {a }}$ ed., Padova: Cedam, 2007. 
PINTO, José Augusto Rodrigues. Processo trabalhista de conhecimento. São Paulo: LTr, 2000.

RAMALHO, Maria do Rosário Palma. Direito do trabalho. Situações laborais individuais. Coimbra: Almedina, 2006.

RAMOS, Elival da Silva. A proteção aos direitos adquiridos no direito constitucional Brasileiro. São Paulo: Saraiva, 2003.

RÁO, Vicente. O direito e a vida dos direitos. São Paulo: Max Limonad, 1952.

REALE, Miguel. Lições Preliminares de Direito. 22. ed. São Paulo: Saraiva, 1995.

REIS, Célia Afonso. Cedência de trabalhadores. Coimbra: Almedina, 2000.

REVISTA DA SEGURIDADE SOCIAL E TRIBUTAÇÃO. Publicação da Associação Nacional dos Auditores Fiscais da Receita Federal do Brasil. Brasília, n. 110, janeiro/março 2012.

ROCHA, Daniel Machado da. Direito fundamental à previdência social. 1. ed. Porto Alegre: Livraria do Advogado, 2004.

; BALTAZAR JUNIOR, J. P. Comentários à lei de benefícios da previdência social. 9. ed. Porto Alegre: Livraria do Advogado, 2009.

ROCHA, Valdir de Oliveira (Coord.). Contribuições previdenciárias. Retenção sobre remuneração relativa a cessão de mão-de-obra. São Paulo: Dialética, 1999.

ROMITA, Arion Sayão. A Terciarização e o Direito do Trabalho. Revista LTr, v.56. n. 3, mar. 1992.

ROSSI, Benôni. Execução de contribuições perante a justiça do trabalho. Dissertação de mestrado em direito, Pontífícia Universidade Católica, São Paulo, 2005.

SANTAELLA, Lucia. Comunicação e pesquisa. São Paulo: Hacker Editores, 2001.

SANTOS, Enoque Ribeiro dos. Temas modernos de direito do trabalho (após a emenda constitucional nº 45/2004). São Paulo: BH, 2005.

SARLET, Ingo Wolfang. A eficácia dos direitos fundamentais. 3. ed. Porto Alegre: Livraria do Advogado, 2003.

Advogado, 2005.

(Coord.). Jurisdição e direitos fundamentais. Porto Alegre: Livraria do

Dignidade da pessoa humana e direitos fundamentais na constituição federal de 1988. 5. ed. Porto Alegre: Livraria do Advogado, 2006. 
Mínimo Existencial e Direito Privado: apontamentos sobre algumas dimensões da possível eficácia dos direitos fundamentais sociais no âmbito das relações jurídicoprivadas. in: SOUZA NETO, Cláudio Pereira de; SARMENTO, Daniel (Coord.). A Constitucionalização do direito. Fundamentos teóricos. aplicações específicas. Rio de Janeiro: Lumen Juris, 2007.

SCHWARZ, Rodrigo Garcia. Contribuições sociais incidentes nas ações trabalhistas. Síntese Trabalhista, São Paulo, n. 154, abr. 2002.

PEREIRA, Caio Mário da Silva. Instituições de Direito Civil. 24. ed. Rio de Janeiro: Ed. Forense, 2011.

SILVA, De Plácido e. Vocabulário Jurídico. 16. ed. Rio de Janeiro: Ed. Forense, 1999.

SILVA, Homero Batista Mateus da. Eficácia contida, ilegalidades e inconstitucionalidades da Lei no 10.035, de 25 de outubro de 2000. Revista Synthesis, São Paulo, n. 32, 2001.

2009.

Curso de Direito do Trabalho Aplicado. Vols. 6 e 8. Rio de Janeiro: Elsevier,

Curso de Direito do Trabalho Aplicado. Vol. 9. Rio de Janeiro: Elsevier, 2010.

SILVA, José Afonso da. Curso de direito constitucional positivo. 16. ed. São Paulo: Malheiros, 1999.

Aplicabilidade das normas constitucionais. 6. ed. São Paulo: Malheiros, 2003.

SILVEIRA, Vladmir Oliveira da; ROCASOLANO, Maria Mendez. DIREITOS HUMANOS: Conceitos, Significados e Funções. São Paulo: Saraiva, 2010.

STUDART, André. Arrecadação e recolhimento das contribuições previdenciárias. São Paulo: Quartier Latin, 2007.

SÜSSEKIND, Arnaldo. Direito constitucional do trabalho. 3. ed. Rio de Janeiro: Renovar, 2004.

Curso de Direito do Trabalho. $3^{\text {a }}$ ed., Rio de Janeiro: Renovar. 2010.

TAVARES, Alexandre Macedo; MUGNAINI, Marcus Vinícius Mendes. As impropriedades da execução ex officio de contribuições à seguridade social emergentes de decisões da justiça do trabalho. Revista Dialética de Direito Tributário, São Paulo, n. 84, p.33-46, 2002.

TAVARES, Marcelo Leonardo. Previdência e assistência social. Legitimação e fundamentação constitucional brasileira. Rio de Janeiro: Lúmen Júris, 2003.

TESORIERE, Giovanni. Diritto processuale del lavoro. 5. ed. Padova: Cedam, 2007.

TOLEDO FILHO, Manuel Carlos de. Execução das contribuições previdenciárias no processo trabalhista. Síntese Trabalhista. São Paulo, n.39, p. 16-21, jan. 2001. 
TORRES, Ricardo Lobo (Org.). Teoria dos direitos fundamentais. Rio de Janeiro: Renovar, 1999.

(Org.).Legitimação dos direitos humanos. Rio de Janeiro: Renovar, 2002.

Tratado de direito constitucional, financeiro e tributário: valores e princípios constitucionais tributários. Rio de Janeiro: Renovar, 2005.

VELlOSO, Andre Pitten; ROCHA, Daniel Machado da et.al. Comentários à lei de custeio da seguridade social. Porto Alegre: Livraria do Advogado, 2007.

VIANNA, João Ernesto Aragonés. Curso de Direito Previdenciário. 4. ed. São Paulo: Atlas, 2011.

VIDA SORIA, José. Manual de seguridad social. 3. ed. Madrid: Tecnos, 2007. 